\title{
Rainwater's well-come: resettling former refugees into New Zealand
}

by

Lucy Stronach

A 120-point thesis submitted to the Victoria University of Wellington in partial fulfilment of the requirements for the degree of Master of Architecture (Professional).

Victoria University of Wellington School of Architecture 


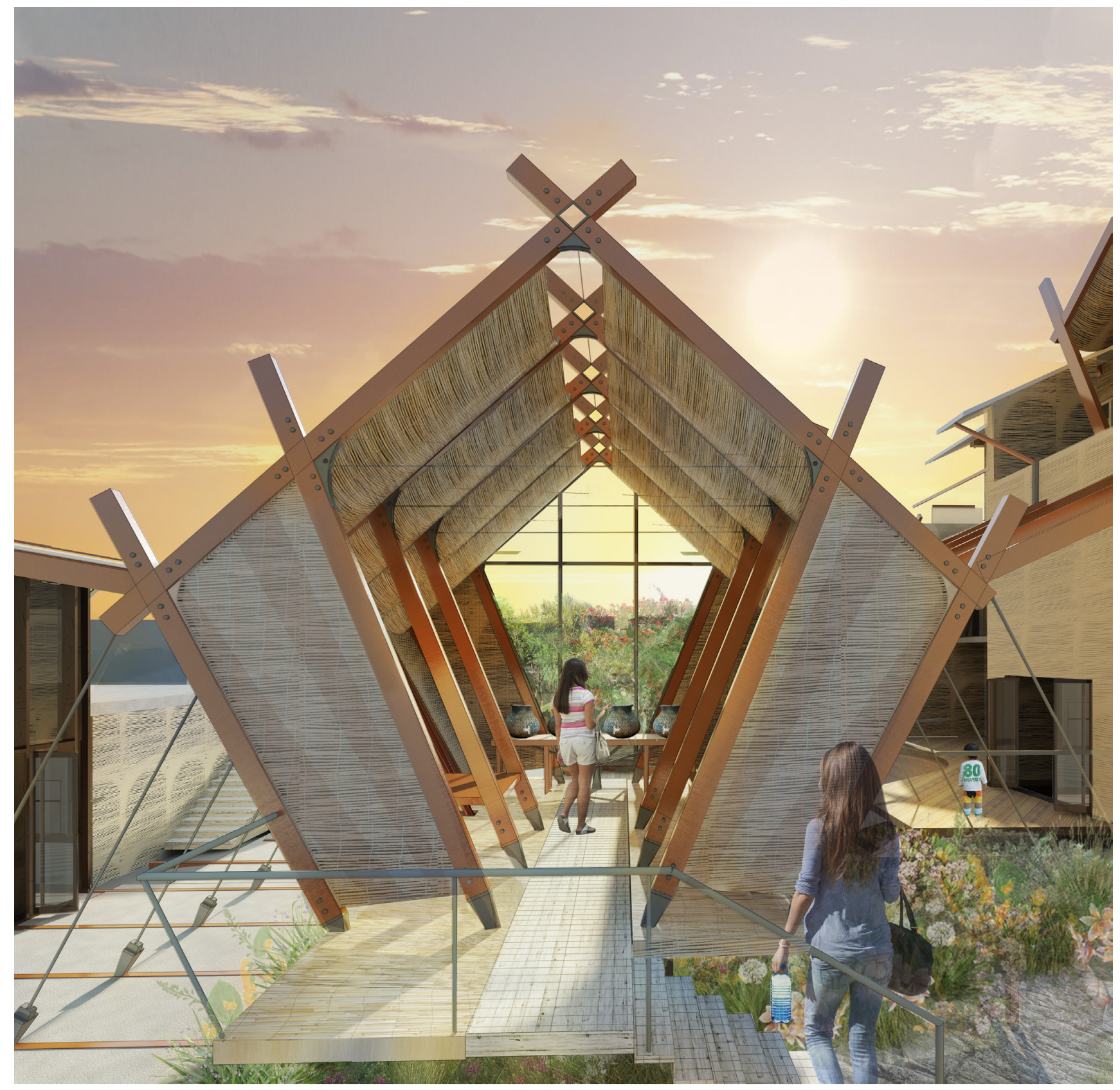

figure 0.01 Rainwater Well: a potential architectural solution for the long-term resettlement of former refugees. 


\section{Abstract}

There are now an unprecedented number of refugees world-wide. The global impact of this is felt in New Zealand, with the refugee quota set to increase in 2018. The refugee crisis is an important design problem that architects must engage with as refugees are a particularly vulnerable group of people. Typically refugees have been assimilated into New Zealand society, however it is known that this process can cause psychological harm.

This thesis seeks to investigate how architecture can thoughtfully and compassionately engage with refugee communities through a design-led investigation which will explore how a dwelling can meet specific cultural and spatial needs while providing opportunities for self-employment, and how a space which is specifically designed for refugee needs can embrace diversity and create opportunities for intercultural dialogue in the wider community.

To investigate this, a sociological framework is used as a lens to examine methods of integration which provide potential ways for architecture to be manifested. Refugees often arrive with few economic resources and can be more reliant on the state and their surrounding communities. The biggest issue felt over longterm resettlement for refugees is a lack of employment which has a direct impact as they don't have enough money to meet their everyday needs. This can also contribute to a negative public opinion about refugees.

To address this issue, this thesis seeks to investigate how a hybrid building type, the shop-house, could be explored to provide refugees a dwelling that could meet their specific cultural and spatial needs and create potential opportunities for selfemployment, self-determination and intercultural contact. The shop-house is a fundamental feature of a city, and can provide an economic foothold for people of all economic means. However, this thesis discovers its limitations and explores an alternative option to allow a refugee community to put down roots and make a new life in a new country which also enriches the host community. 


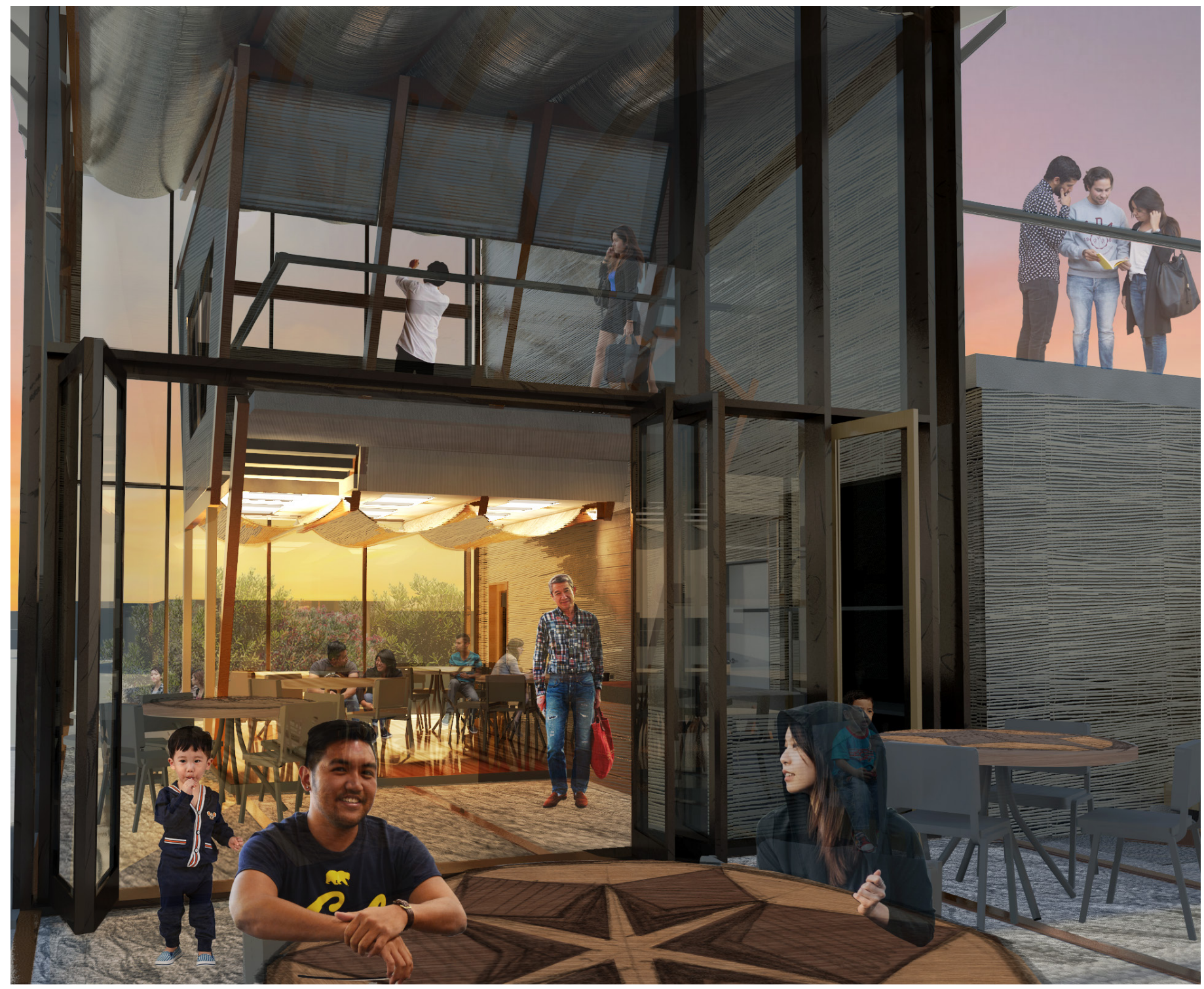

Figure 0.02

The Nest at dusk: a flexible space of business and community. 


\section{Acknowledgements}

A thesis is a massive endeavour, which I could not have

completed without the help of the people around me. And so, I would like to thank my supervisors: Dr Fabrico Chicca and Dr Maibritt Pedersen Zari for all their advice, patience and help. Alex Page from Caduceus for lending me his handy

Revit lighting pack. Christalin

Thangpawl, the chairperson of the National Myanmar Ethnics Groups Council, for her generosity and caring. And of course, my family. I couldn't have done this without my parents, Joy and Wayne who have always stood by me. 


\section{Table of contents}

Introduction 1

Problem statement 5

Research question, aim and objectives 12

Methodology 13

Thesis structure 15

Section One - Assimilation, Integration, Migrancy and Refugees 17

Drifting: architecture and migrancy 19

Selective acculturation $\quad 21$

Reflection 23

Section Two - State housing $\quad 25$

Housing New Zealand homes $\quad 27$

Precedent review $\quad 29$

Reflection 35

Section Three - The Shop-house 37

$\begin{array}{ll}\text { Theorists } & 39\end{array}$

The veranda 43

Street orientation $\quad 45$

Precedent review $\quad 47$

Reflection $\quad 51$

Section Four - Myanmar Ethnics (Burma) 53

The People $\quad 55$

Interview process $\quad 57$

The Vernacular dwelling $\quad 59$

Spatial programming 61

Self-employment opportunities 63

Precedent review 65

$\begin{array}{ll}\text { Reflection } & 71\end{array}$ 
$\begin{array}{ll}\text { Section Five - Site analysis } & 73\end{array}$

Direct locality $\quad 79$

$\begin{array}{ll}\text { Shops } & 81\end{array}$

Gardening 83

Section Six - Preliminary design $\quad 85$

$\begin{array}{ll}\text { Initial review } & 87\end{array}$

Design moves $\quad 89$

$\begin{array}{ll}\text { Shop-house type } 1 & 97\end{array}$

Reflection and final review $\quad 111$

Section Seven - Community interaction 113

$\begin{array}{ll}\text { Precedent review } & 115\end{array}$

$\begin{array}{ll}\text { Fresh water and Precedent review } & 119\end{array}$

$\begin{array}{lr}\text { Section Eight - Developed design } & 127\end{array}$

$\begin{array}{ll}\text { News paper section } & 137\end{array}$

Journey through Rainwater's Well 147

Water's journey 151

Structure and Construction 157

Plans 159

Section Nine - Final Reflection and Conclusion 163

$\begin{array}{ll}\text { Figure list } & 171\end{array}$

$\begin{array}{ll}\text { Works Cited } & 175\end{array}$

$\begin{array}{ll}\text { Appendix } & 181\end{array}$ 


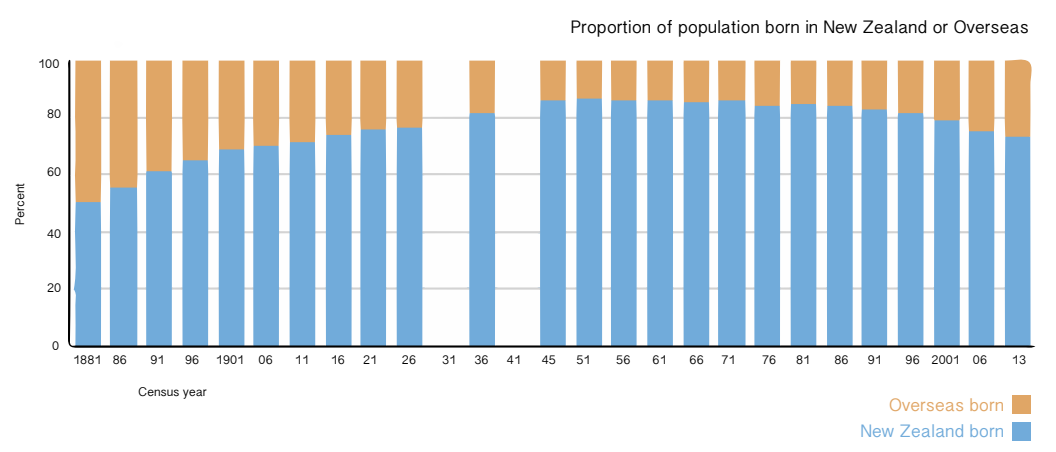

Figure 0.03 Graph drawn from Statistics New Zealand showing percentage of New Zealand population who were born overseas.

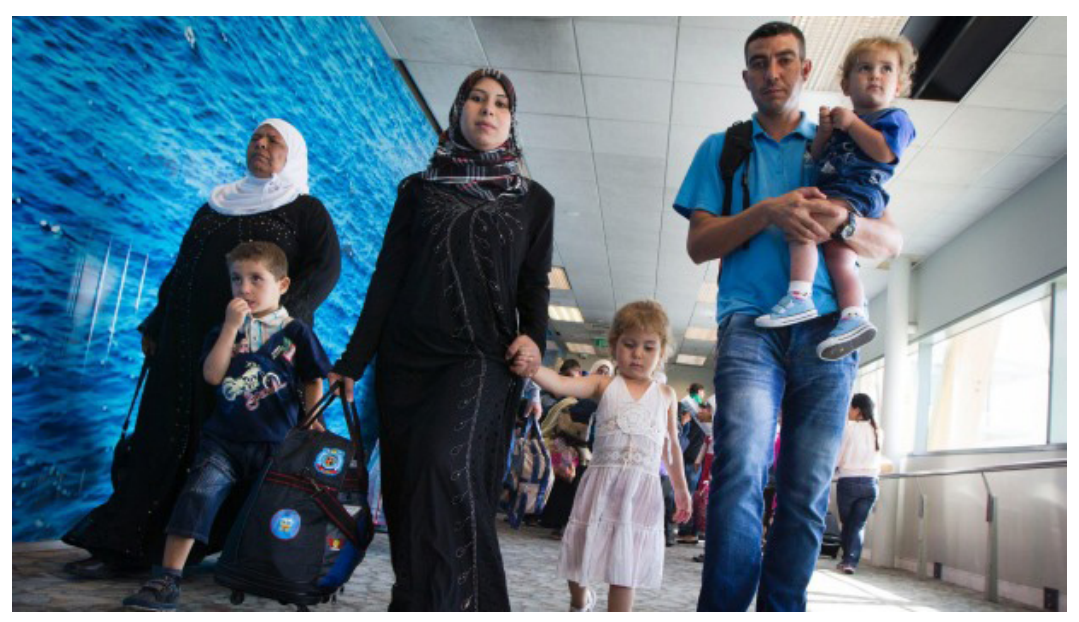

Figure 0.04

Refugees arriving in New Zealand. Photo by Ross Giblin 


\section{Introduction}

There are an unprecedented number of displaced people across the world. The United Nations Refugee Agency states that there are 65.3 million displaced people, with 21.3 million of those registered as refugees. Refugees come from all parts of the world, and they bring their culture and experiences to their new resettlement country. Large numbers of refugees across the world are having a global impact which is also experienced in New Zealand, with the refugee quota set to increase in 2018.

"Designers cannot just stand by and watch the refugee crisis unfold" - Richard van der Laken, 2016

With this statement Richard van der Laken is taking the position that designers have a moral responsibility to be engaged with the problem of finding ways to welcome and support refugees effectively. His statement points out that the refugee crisis is an important design problem that architects must engage with.
The question remains, how can architects use their expertise as creators of spaces and places to meaningfully engage in this aspect of a changing world?

While refugees are a comparatively small percentage in number within general migration statistics, (MacKenzie, 2016) they are a particularly vulnerable group of people (Marlowe et al, 2014). Refugees often arrive in a new country without many economic resources and thus are more reliant on the state and their surrounding communities.

In New Zealand, an increasing percentage of the population are born overseas (figure 0.03), which shows a wider trend of increasing cultural diversity. Internationally, other Western countries have been challenged with issues related to increasing diversity (Cantle, 2012 and Inglehart \& Norris, 2016), which can result in negative public opinions about refugee or migrant communities. 


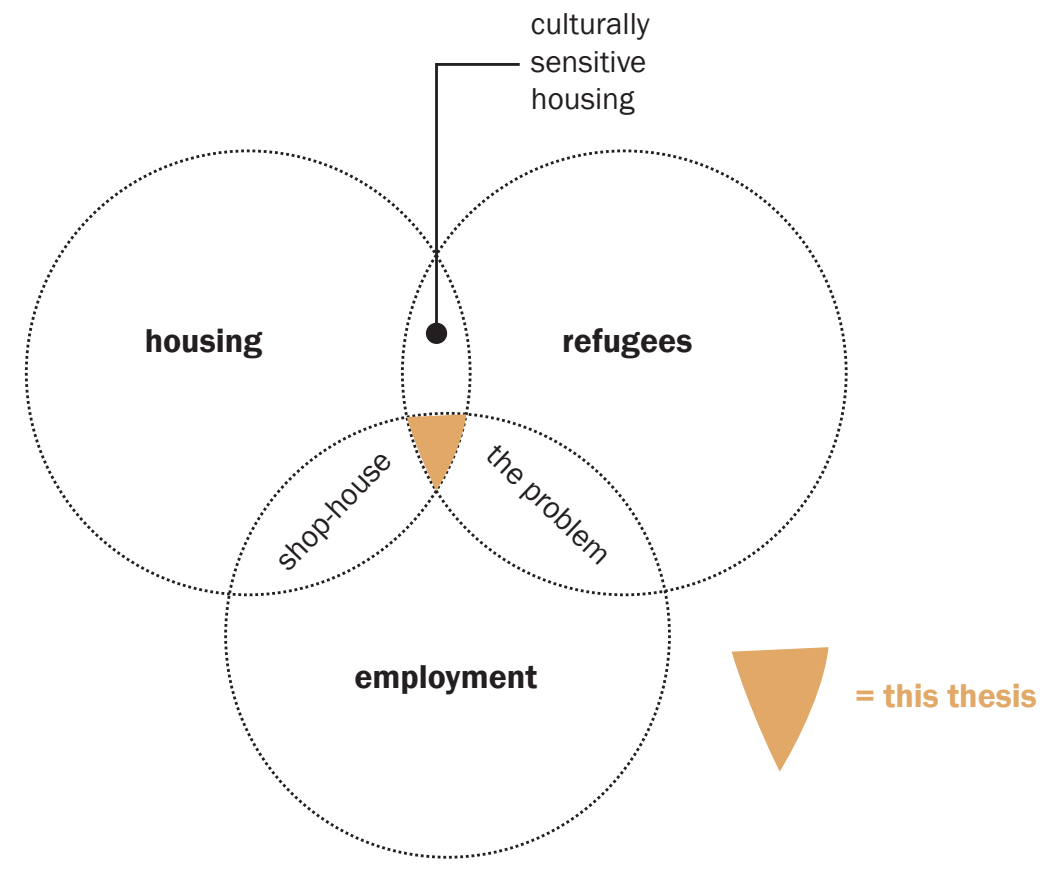

Figure $0.05 \quad$ The core ideas and how they link together to produce a design-led research thesis. 
A solution to this is presented by Ward and Masgoret (2011), who state that "increasing intercultural contact leads to more positive attitudes toward immigrants". Furthermore, Refugee Cities manifesto (2016) point out that "refugees have proven to be incredibly dynamic and creative when given the opportunity - creating businesses and jobs, providing local goods and services, boosting exports, and increasing the overall income of the host country". This demonstrates a potential opportunity for a host country to enable refugees to thrive, rather than just survive, in their new homes.
This thesis seeks to investigate therefore how architecture can be responsive to the refugee resettlement process in ways which:

$1 /$ ensure refugees are provided with dwellings that meet their specific cultural and spatial needs while providing opportunities for self-employment and

2/ create opportunities for the development of spaces which are specifically designed for refugee needs that also embrace diversity and intercultural dialogue in the wider community. 

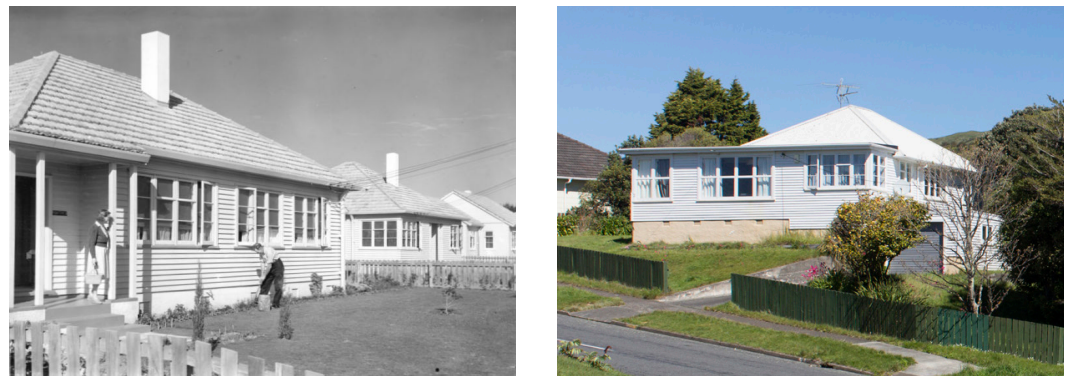

Figure $0.06 \quad$ State housing by Unknown (left) and, photo by author

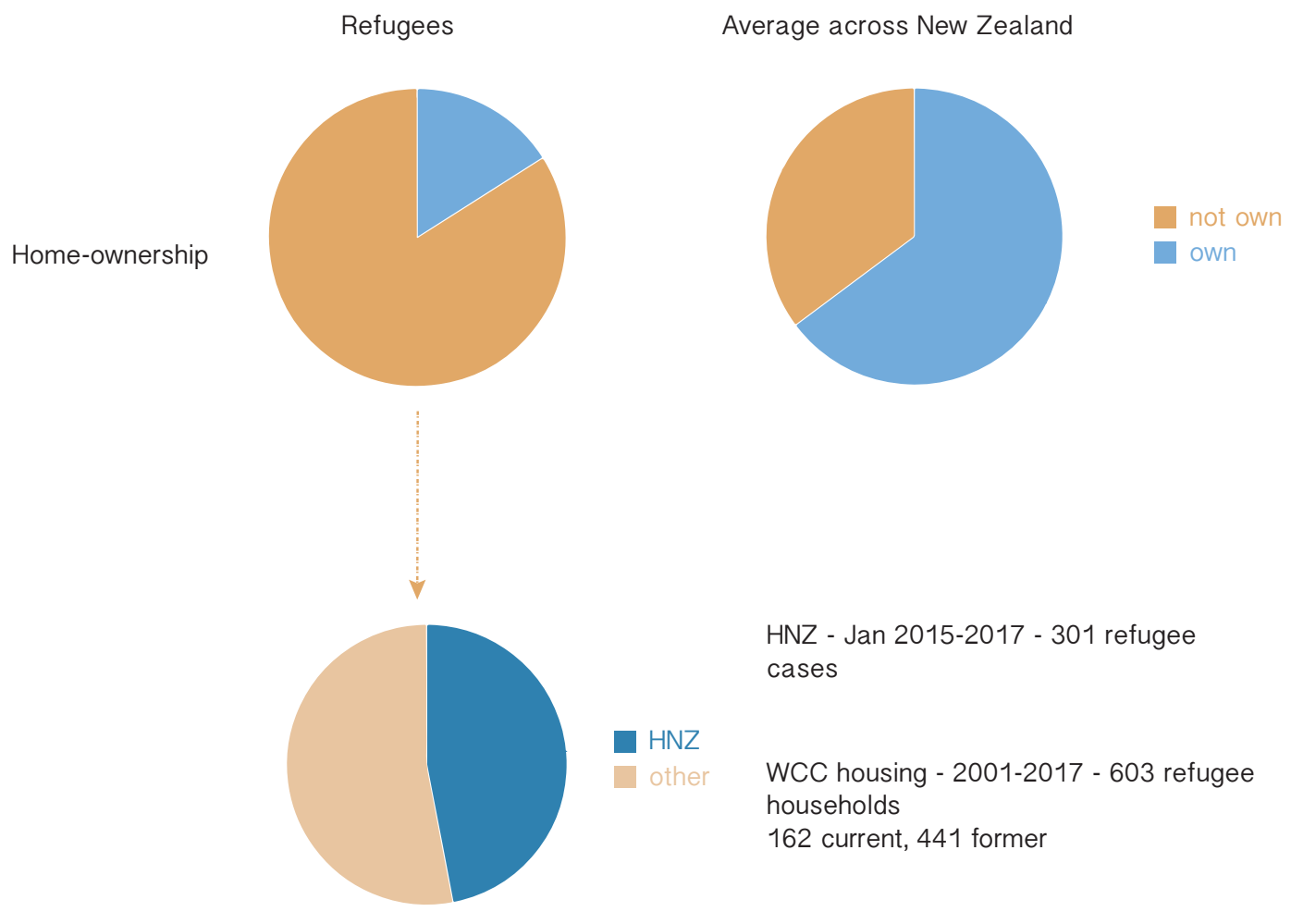

Figure 0.07 Percentage of refugee home-ownership vs wider New Zealand home-ownership, and the percentage of non-home-owning refugees living in Housing New Zealand houses. 


\section{Problem Statement}

\section{According to Gruner et al} (2012) in a multi-year research programme developed to gain a better understanding of the issues arising from the long-term resettlement of refugees, lack of employment is the biggest issue within the refugee community, with 51\% receiving government benefits as their main source of income and $63 \%$ not having enough money to meet their everyday needs (Gruner, 2012:5).

\section{In 2015, the Ministry of} Business, Innovation and Employment (MBIE) conducted a survey designed to measure New Zealanders' attitudes towards immigration. The outcome of this survey was that while New Zealanders generally feel positively about migrants, they are the least positive about refugees, and are chiefly concerned with jobs and impact on housing and infrastructure. Refugees can be seen as having the potential to be economic burdens (MacKenzie, 2016) which could result in a negative public opinion about refugee communities. This is why finding ways to solve employment issues for this group are important.
Currently Housing New Zealand (HNZ) houses or facilitates housing for refugees (figures $0.06 \& 0.07$ ), with $40 \%$ of former refugees living in HNZ housing (Gruner et al, 2012:3). A building type which can play a role in generating income for populations who do not have much income is the shop-house (Davis, 2012) because it can require little income to run (Spoonley, 2012). HNZ does not currently offer housing types like the shop-house type, which could play a role in generating income for refugee communities.

Forward-thinking methods of integration are investigated to design a space which is responsive to refugees by meeting their specific cultural and spatial need including embracing diversity and potentially increasing intercultural contact. Generally, refugees have been assimilated into New Zealand society (Marlowe et al, 2014), which is a process which can cause psychological harm (Cooper, 2014:261). Assimilation is understood as a one-way process, where the newcomers transform themselves to the host society (Kivisto, 2016:6). 

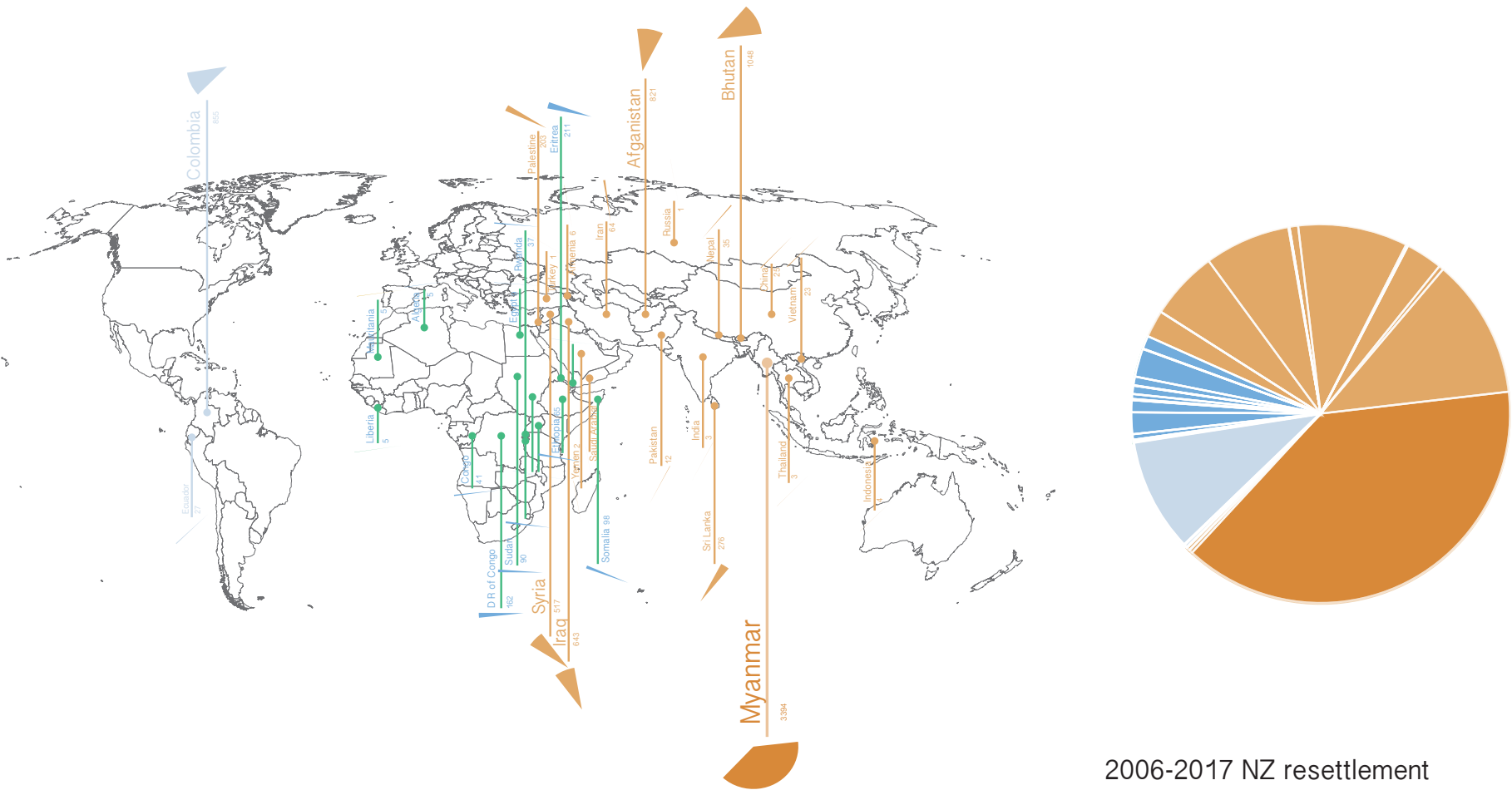

2006-2017 NZ resettlement
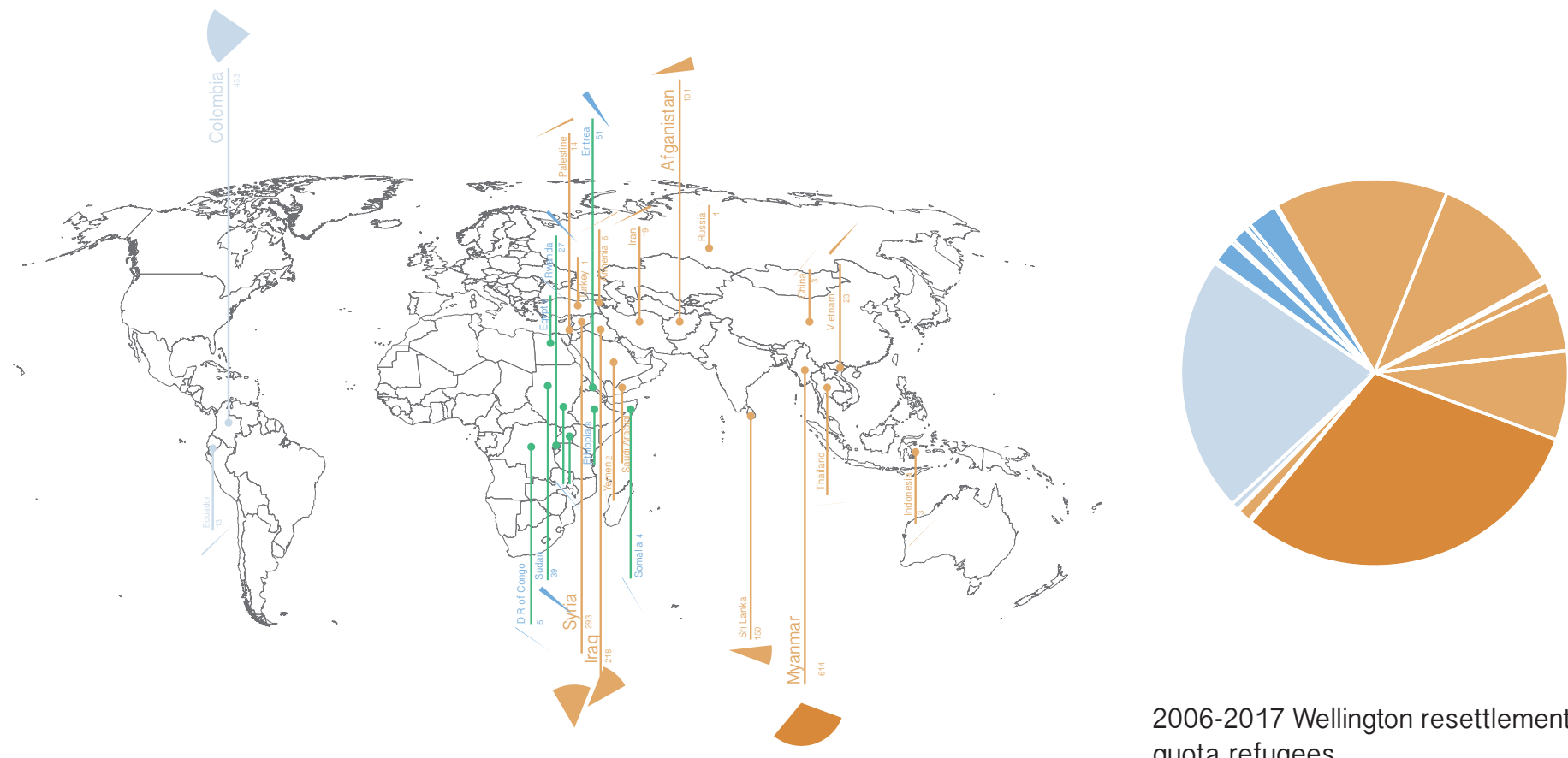

2006-2017 Wellington resettlement quota refugees

Figure 0.11 These diagrams show that the Myanmar Ethnics is the largest group over the last decade as part of the quota refugee resettlement program.

The two largest groups in Wellington over the last decade are Myanmar Ethnic and Colombian. 

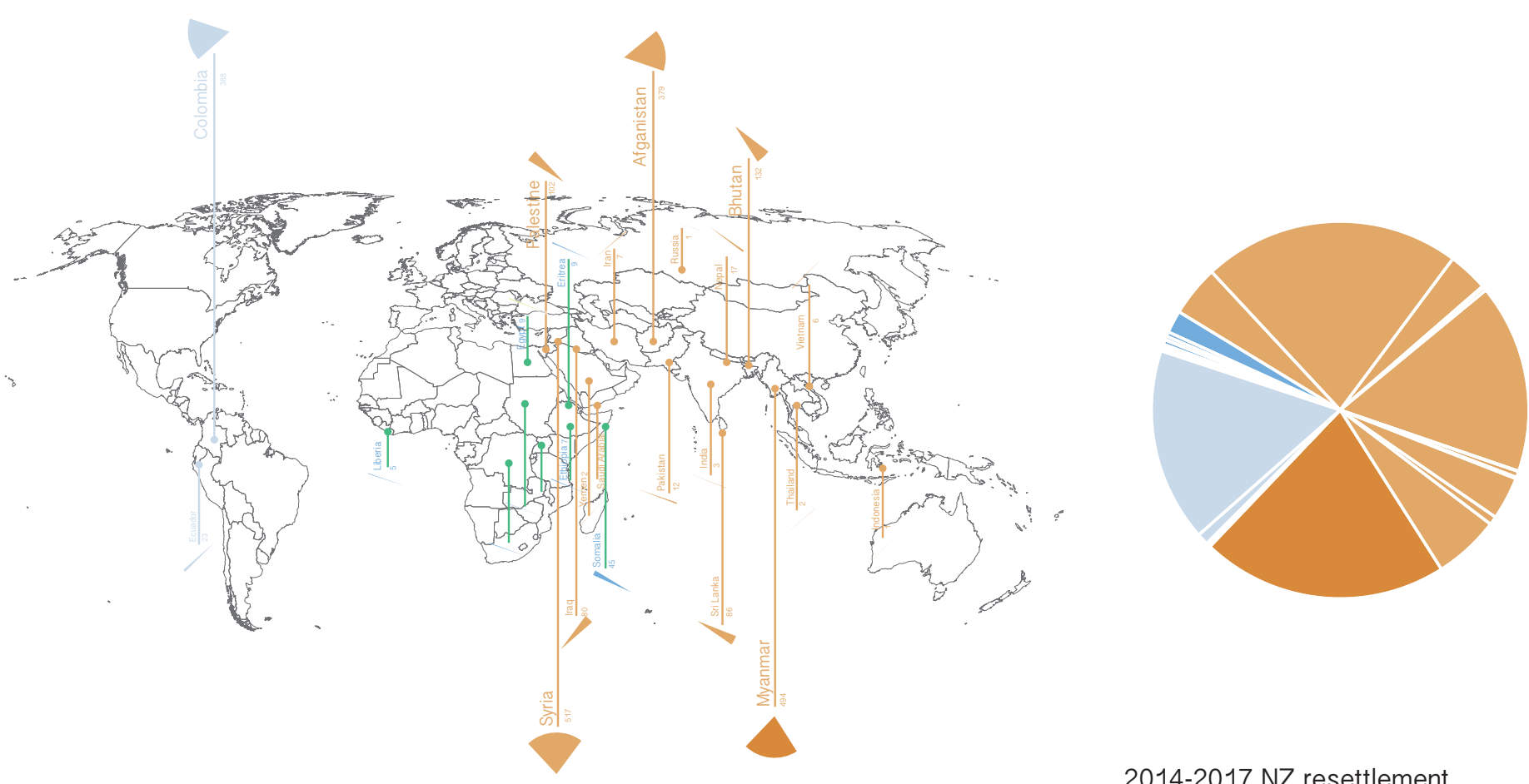

2014-2017 NZ resettlement

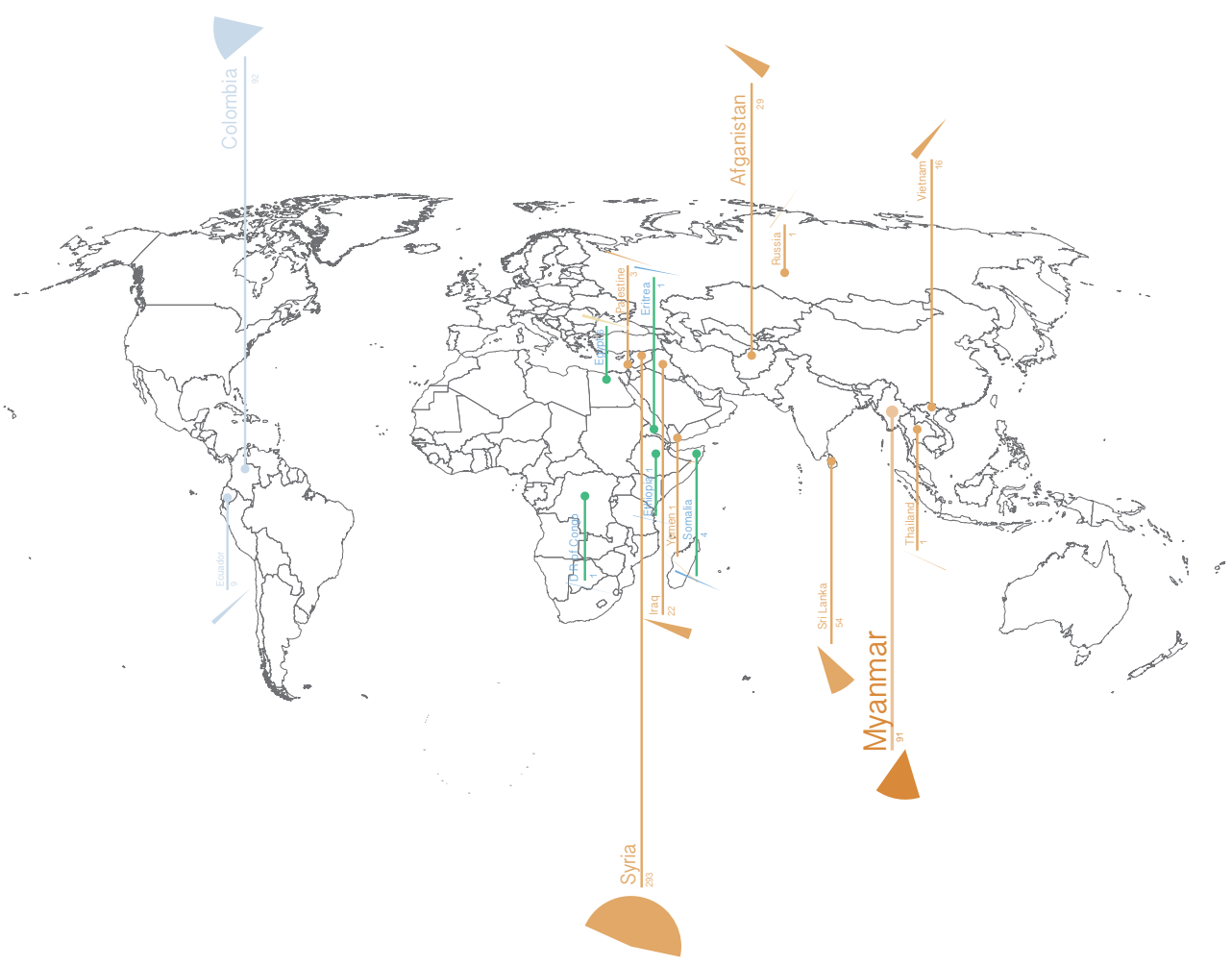

2014-2017 Wellington resettlement quota refugees

Figure $0.12 \quad$ Continuing Figure 0.11, showing quota refugee resettlement since 2014. In this period Syrian refugees outnumber Myanmar Ethnics. However, the Myanmar Ethnics are still steadily being granted asylum in New Zealand. 



\section{Research question, aim and objectives}

This thesis seeks to investigate a potential method of integration which could more thoughtfully and compassionately resettle refugee populations through an architecture which integrates without assimilating - by meeting refugees' specific cultural and spatial needs, providing a potential opportunity for selfemployment and potentially increasing intercultural contact.

To do this, a sociological framework is defined and examined which will provide a lens through which to investigate, test and analyse architecture. Integration is a complex process, which is not only experienced by refugees but also by the wider community. As a dwelling with a commercial function, the shop-house can become the site where different communities interact and various methods of integration can be tested. Furthermore, the shop-house type is investigated to gain an understanding of how incorporating selfemployment and dwelling could help to mitigate the issue of employment within the refugee community.
Integration is seen as a process of change and this thesis sees the shop-house as a potential site for integration. As such, the architecture will be designed to evolve and adapt through a design-led investigation which will test potential methods of change through integration.

This thesis seeks to investigate the long-term needs of refugee communities within New Zealand by asking: How can a dwelling, which is designed to meet specific cultural and spatial needs of a refugee community provide opportunities for selfemployment, embrace diversity and increase intercultural contact.

As a thesis which seeks to provide a potential solution specific to the long-term resettlement needs of refugee populations in New Zealand, this thesis will focus on a specific refugee group. The largest refugee group in New Zealand is the Myanmar Ethnics (fig $\mathrm{x}$ ), who are also the most permanent group with only $2 \%$ of those who had been granted residence leaving New Zealand (Tan, 2013). 


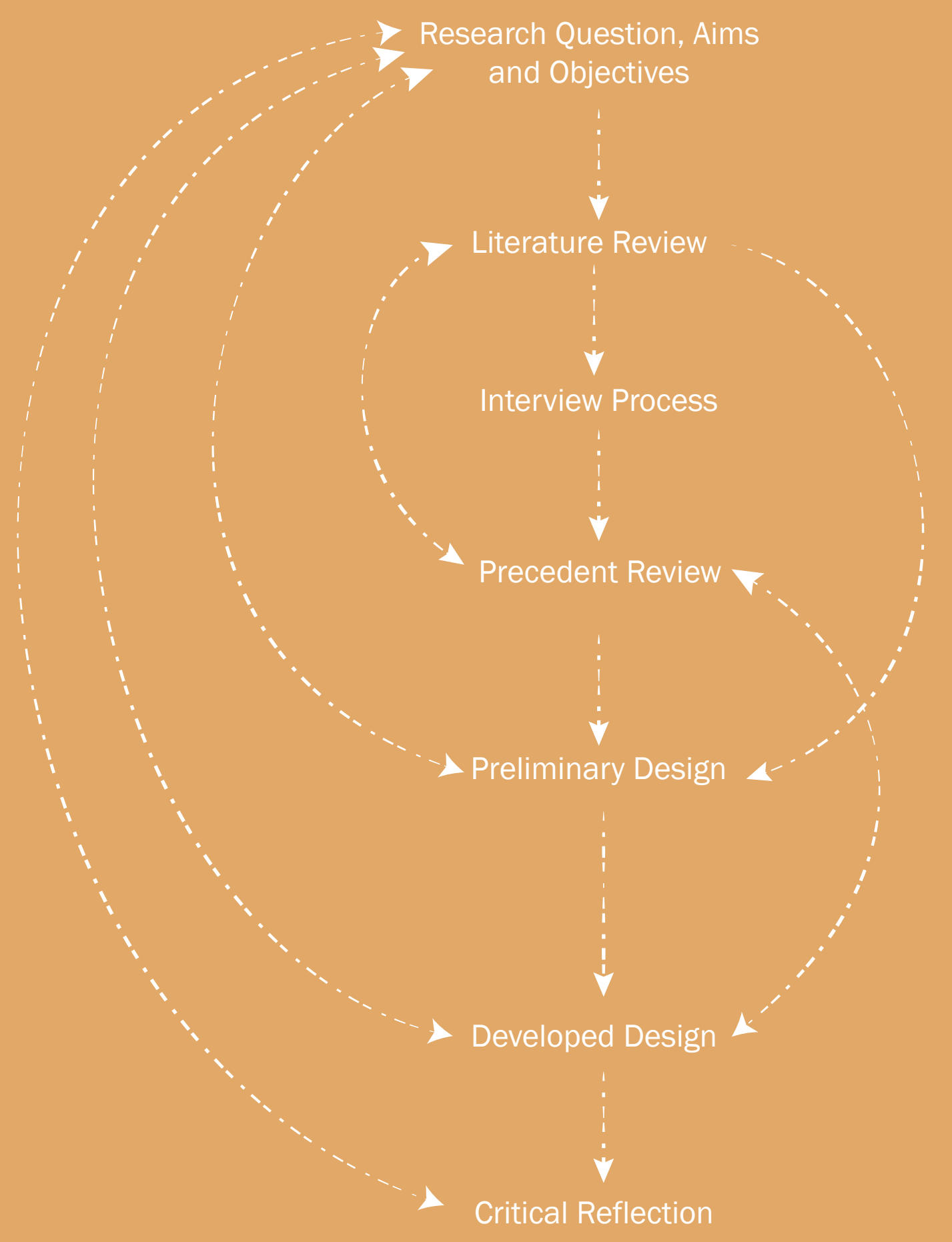




\section{methodology}

This thesis is a design-led research thesis: this means that in-depth literature and precedent reviews are followed by iterative and developed design investigations, which are led by critical reflection as a means to progress.

\begin{abstract}
A literature review is initially conducted on refugees and integration, which is used to discover a research lens which will be used to focus and define further research and create a basis from which to conduct a critical and reflective iterative design process.
\end{abstract}

As a thesis which is focused on the specific needs of a community, an interview process will then be conducted which will provide the information for the community's specific needs. Next, the information from the interview process will be further developed through a precedent review.

The preliminary design process will then investigate the research through an experimental and iterative design process. This will then be critically examined and the information from this will lead to the developed design outcome.

The final stage is a conclusion which will summarise the research and evaluate the design outcomes. 


\section{Thesis structure}

Several elements must be examined and drawn upon in this thesis. These are examined as separate sections (sections 1-4), before findings are drawn together as a series of design experiments and critical reflection (sections 5 -7). Sections 8 \& 9 conclude the research through a developed design and a final critical reflection.

\section{Section One begins by} identifying a sociological lens, which is then used to critically investigate how two of the New Zealand Refugee Resettlement Strategy's goals - self-sufficiency and housing - could potentially be approached through architectural intervention. This lens is then used to identify key disciplinary themes, specifically the role that architecture can play in ideas of migration and multiculturalism.

Section Two presents three contemporary case studies in public housing in New Zealand, which could be representative of the changing face of public housing. Then a potential reason for why businesses are not run from public housing is examined.

Section Three investigates the hybrid type known as the shop-house. It begins with a brief description leading on to a discussion of the context, ideas and relevance of two prominent theorists, Frances Holliss and Howard Davis. After this a typical architectural device known as the veranda is examined within the New Zealand context. This examination broadly describes its historical roots, its usefulness as a liminal zone and shows some common manifestations. This section then goes on to show and discuss some typical ways in which a shop-house can be orientated towards the street. Finally, three examples of shop-houses in New Zealand are investigated to gain an understanding of context.

Section Four is a specific exploration of the chosen refugee group, the Myanmar Ethnics. It begins by describing and justifying the interview process. This is followed by a broad description of this refugee group which presents the diversity within the group itself. Then, vernacular Myanmar architecture is discussed and examined, covering some aesthetic and construction elements but mostly focusing on spatial and programmatic elements which are discussed in direct relation to the information 
gathered from the interview process. The final element of the spatial and programmatic understanding is derived from the type of business that the group members interviewed were interested in running. The final part of this section is a precedent review which is conducted to gather information on construction techniques and aesthetic elements.

Section Five begins with a discussion of initial design experiments and describes the feedback received from this.

This section then presents a site analysis, which examines a specific site and its environment.

\section{Section Six presents}

preliminary design experiments which investigated ideas such as how to create a liminal zone, interface or relationship between the employment and dwelling functions on the site. This culminates in a shop-house type manifestation which is based around the idea of a curved interface. A discussion of the final review leads to a critical examination of this iteration which leads to further exploration.

Section Seven is a re-evaluation of initial designs and explores further potential to encourage wider community interaction in the project to support an integration process. A brief discussion of Wellington City Council's Community Action Program is followed by two small scale precedents which have either created community interaction or are interventions designed to achieve this.

Section Eight presents the developed design which begins with explorations of site and function. The developed design descriptions are complemented through an imagined narrative device. The intention of this is to show how the project could be subjectively experienced. Next the centerpiece of the project, the Rainwater Well is described to demonstrate the central journey or the story of the project. Plans and sections are presented and finally pragmatic detailed elements of the project are examined, such as how the rainwater tank and garden function and how the structural system of the Rainwater Well is constructed. Lastly, this thesis offers a conclusion which discusses both successful and unsuccessful elements and where further explorations could take the project. 
1 


\section{Assimilation, Integration, Migrancy, Refugees.}

This section examines three key texts: 'Drifting: architecture and migrancy' (Cairns, 2012), Alejandro Portes' segmented assimilation thesis, and a multi-disciplinary examination of the New Zealand Refugee Resettlement Strategy. These texts are investigated to gain both a broad understanding of the disciplinary tendencies towards immigration and a specific understanding of refugees and architecture. It investigates a sociological framework which can be used as a lens to examine how refugees could be integrated into a new host country.

This lens is discovered through a critical examination of the New Zealand Resettlement Strategy by Marlow, Bartley and Hibtit (2014). This is a multidisciplinary team: Marlowe and Bartley are in the Faculty of Education and Social Work at Auckland University and Hibtit is a resettlement case officer at MBIE and a former refugee who is also the Vice-President of the Eritrean Community of New Zealand Inc. With a combination of critical academic thinking and on-the-ground pragmatism, the sociological framework this team uses to critique the New Zealand Resettlement Strategy is an appropriate lens with which to approach this design project.

Refugees are not migrants, 'Refugees are persons fleeing armed conflict or persecution.' (UNHCR, 2016). Refugees who are resettled in New Zealand do not get to choose their resettlement location (New Zealand Red Cross, 2017) which could mean that they have few resources to aid their establishment in the community. 


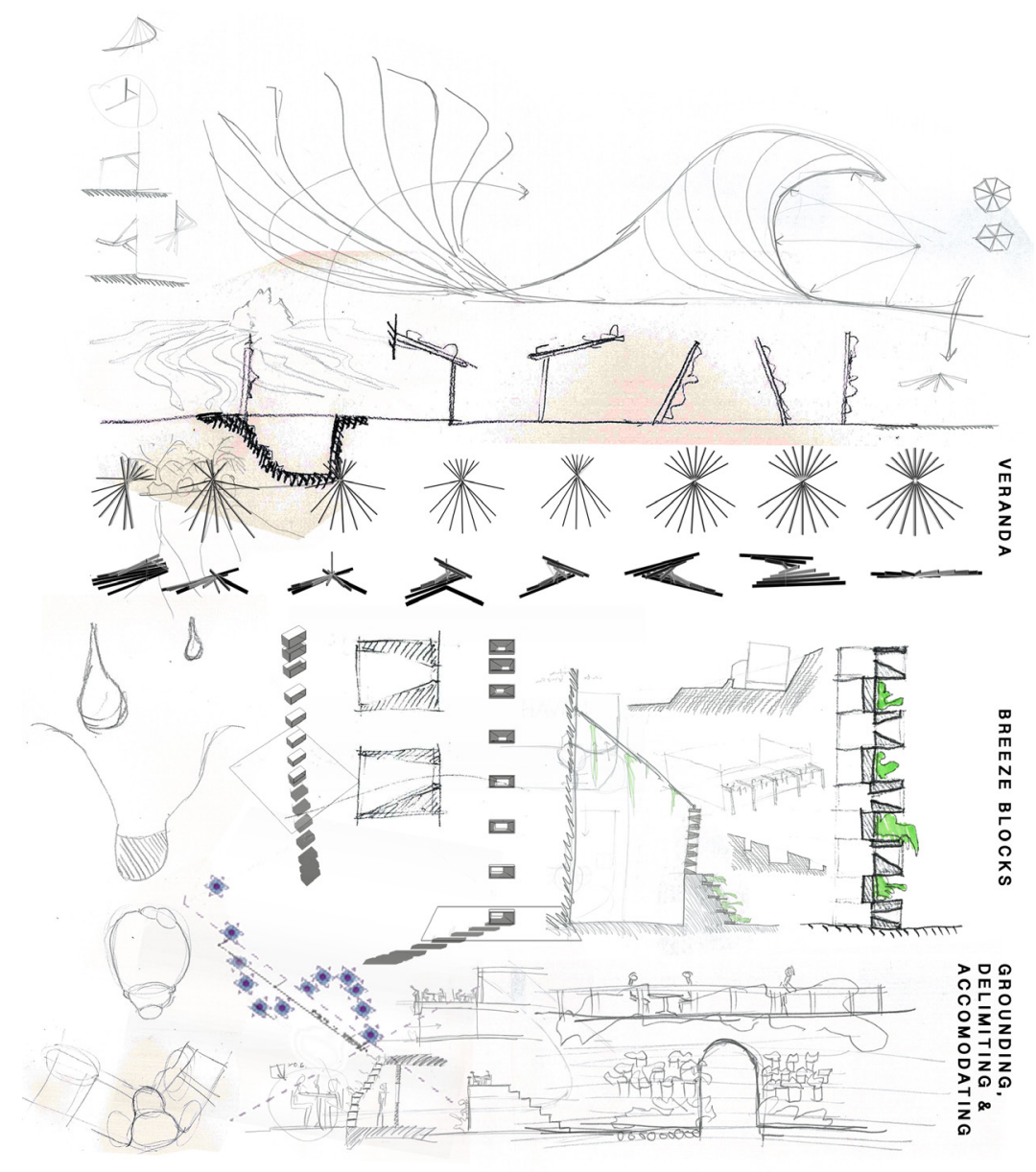

Figure 1.01 This collage shows various design explorations conducted around the key themes discovered in the research. Ideas of the binary relationship are explored through contrasting permanent materials, such as concrete breeze blocks, with changing materials such as plants. This juxtaposition is also explored by analysing the form and mathematics of waves, which are seen to be both fluid and permanent. This analysis is taken and applied to an early veranda type, and parametric experiments are conducted with an extrapolated sin-curve. Grounding, delimiting and accommodating is looked at through these experiments in relationships between the dwellers of the site and the public. 


\section{Drifting: architecture and migrancy}

The text 'Drifting: architecture and migrancy' (Cairns, 2012) is a collection of essays from an international range of authors. It began life in 1997 as a conference held in Melbourne titled 'Building Dwelling Drifting: migrancy and the limits of architecture'. It is used to gain a broad disciplinary understanding of architecture and migrancy and discover key themes which can be investigated through an iterative design process. Key themes discovered from this investigation are:

- The binary relationship of architecture and migration, which is 'settlement, stability and permanence' and 'movement, flux and fluidity'
(Cairns, 2012:1). Cairns states that migrants are viewed as unstable members of a population because they have loyalty to multiple locations (Cairns, 2012:42) which has meant that migrants are viewed as a 'threat' which needs to be resolved (Cairns, 2012:3) and,

- Cairns states that architecture played a role in resolving' this 'threat' through architecture's capacity for 'grounding, delimiting and accommodating', which is manifested in urban design through segregated enclaves and through individual dwellings scattered through host populations in the name of assimilation (Cairns, 2012:2). 
Methods of Integration

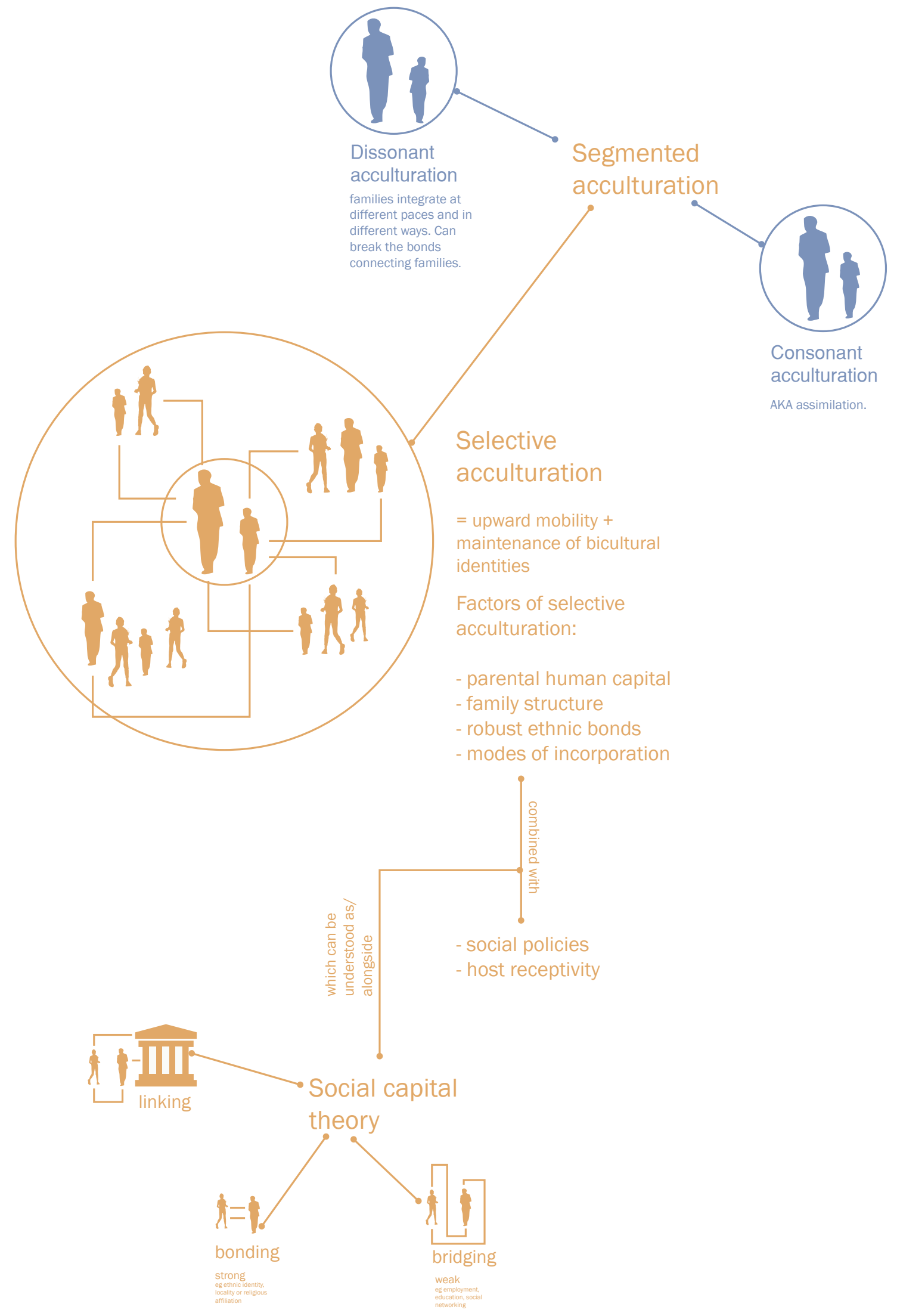

Figure 1.02

Diagram connecting the ideas behind the segmented

assimilation thesis. 


\section{Selective Acculturation}

The segmented assimilation thesis (figure 1.02) developed by Alejandro Portes with various collaborators in the 1990s, is a theoretical framework developed to understand the processes by which second-generation immigrants could integrate into the host culture of a country (Zhou, 1997). It provides a useful framework for this research through descriptions of what Marlowe, Bartley and Hibtit (2014) suggest is the most positive method, which is 'selective acculturation' (Marlowe et al, 2014: 65). This framework is useful because it states two essential social/ economic resources (Marlowe et al, 2014:61) which can potentially be spatialised, such as 'parental human capital' and 'robust ethnic bonds'.

In New Zealand, refugees are resettled by the New Zealand Refugee Resettlement Strategy, which states that: "Successful settlement is achieved when people can participate fully in their new community" (Immigration New Zealand, 2013:4).

The Strategy has defined five goals to achieve successful settlement, which are:

- Self-sufficiency: all working-age refugees are in paid work or supported by a family member in paid work.
- Participation: Refugees actively participate in New Zealand life and have a strong sense of belonging here.

- Health and Well-being: Refugees and their families enjoy healthy, safe and independent lives.

- Education: Refugees have English language skills that help them participate in education and daily life.

- Housing: Refugees live in safe, secure, healthy and affordable homes without needing government housing help.

These goals describe a desired outcome but not a process or method to achieve this, and so Marlowe, Bartley and Hibtit's (2014) critical examination of the Resettlement Strategy, which uses Portes segmented assimilation thesis as a lens, suggests that: - the refugee family or individual's role is prioritised, which neglects both the importance of community (Marlowe et al, 2014:66) and the role of the host society (Marlowe et al, 2014:62)

- the exclusion of the value of wider social capital resources such as, bridging, bonding and linking capital and how they relate to Ager \& Strang's 'means and markers' which are: housing, health, education and employment (Marlowe et al, 2014:65). 


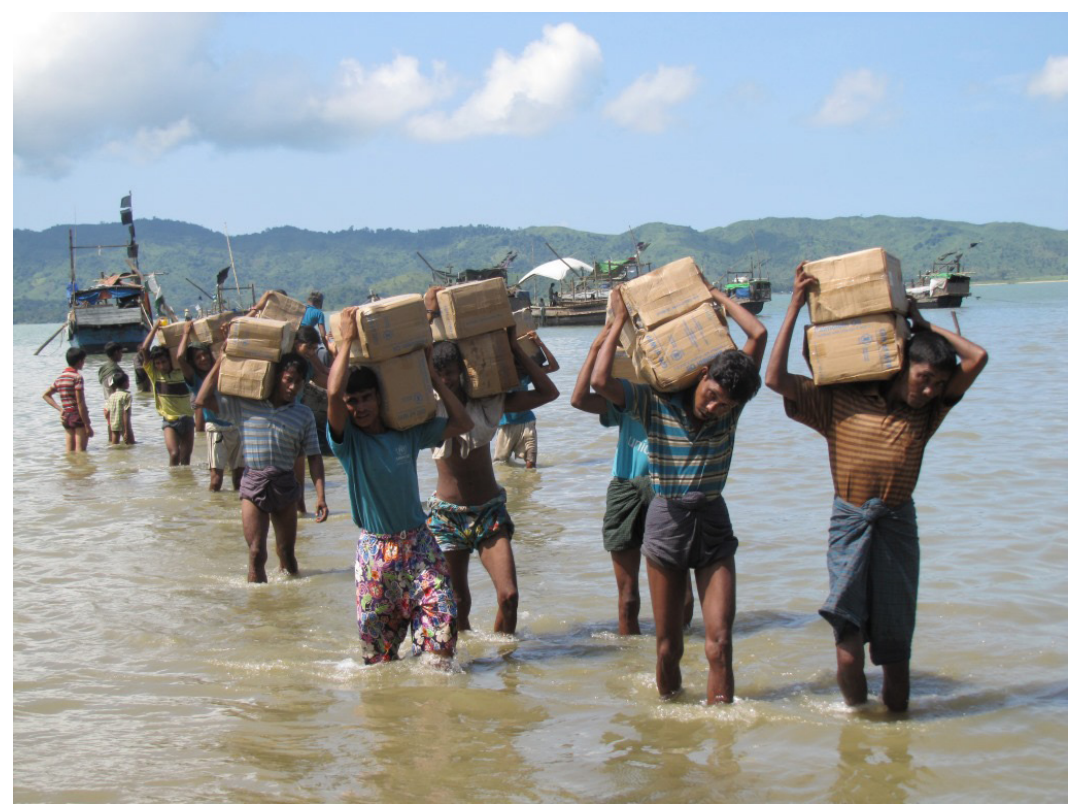

Figure 1.03

Refugees in Myanmar, photo by Mathias Eick 


\section{Reflection}

This investigation reveals both the broad and specific role that architecture can play in integration over the long-term resettlement of refugees. Cairn's research, while it mainly discusses migrants, provides a broad disciplinary understanding, which can be understood architecturally as: - migrants can be seen as a 'threat', which can be resolved through assimilative designs. This occurs in architecture's capacity for "grounding, delimiting and accommodating'. As assimilation is psychologically harmful to refugees (Cooper, 2014:261), architecture should question whether there is a responsibility to look beyond assimilative designs for refugees.

Marlowe, Bartley and Hibtit's critical examination of the New Zealand Refugee Resettlement Strategy reveals that the wider community could play a larger role in the integration of refugees. This examination used Portes' segmented assimilation thesis as a lens to analyse the Refugee Resettlement Strategy, and suggested that 'selective acculturation' is the most positive method of integration. This thesis then uses the lens of selective acculturation to posit that 'parental human capital' could potentially be created by providing a dwelling which also provides the potential opportunity for self-employment and, that 'robust ethnic bonds' are encouraged by creating spaces which could become potential nodes within the community, such as:

- a commercial location run by refugee community members, - a study space for children which is also open to the wider community,

- a community meeting room, - public outdoor space, such as a sunny courtyard and, - a place that draws people from wider communities together.

Considering methods of integration is a valuable architectural investigation when designing for refugees. This is because architecture can act in assimilative ways which are psychologically harmful to refugees. Currently $40 \%$ of former refugees are living in Housing New Zealand (HNZ) homes, which are designed for Pakeha culture and generally manifest as dwellings suitable for a traditional nuclear family unit. The next section investigates social housing in New Zealand, to examine the potential of social housing to meet specific cultural and spatial needs for a community. 


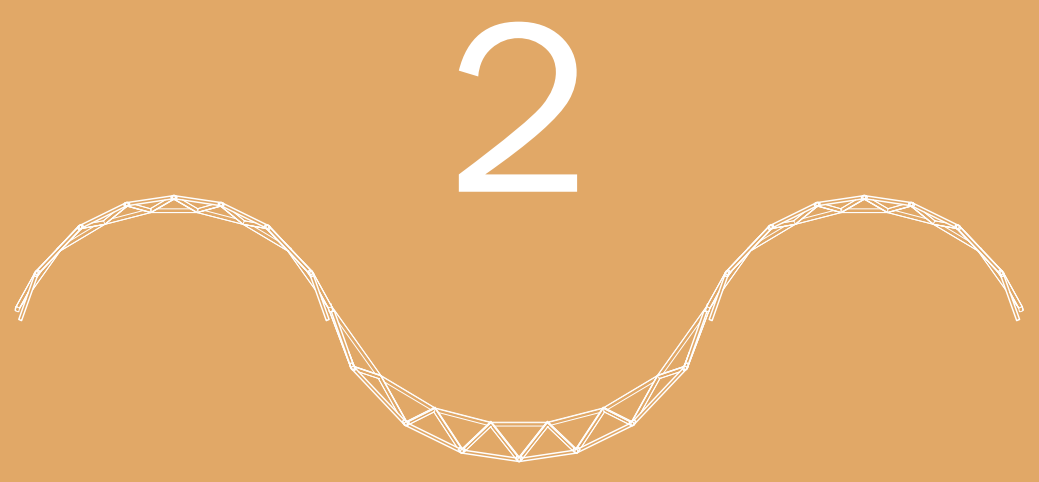




\section{State housing}

This section looks at social housing in relation to refugees in New Zealand to investigate how it could change in the future. Given this thesis's focus on providing a dwelling which both integrates and provides the potential opportunity for self-employment for refugees, three varied and contemporary examples of social housing are examined to investigate the potential of social housing to provide these opportunities. This then leads onto a discussion on potential reasons why social housing does not provide dwellings from which a business could also operate. 


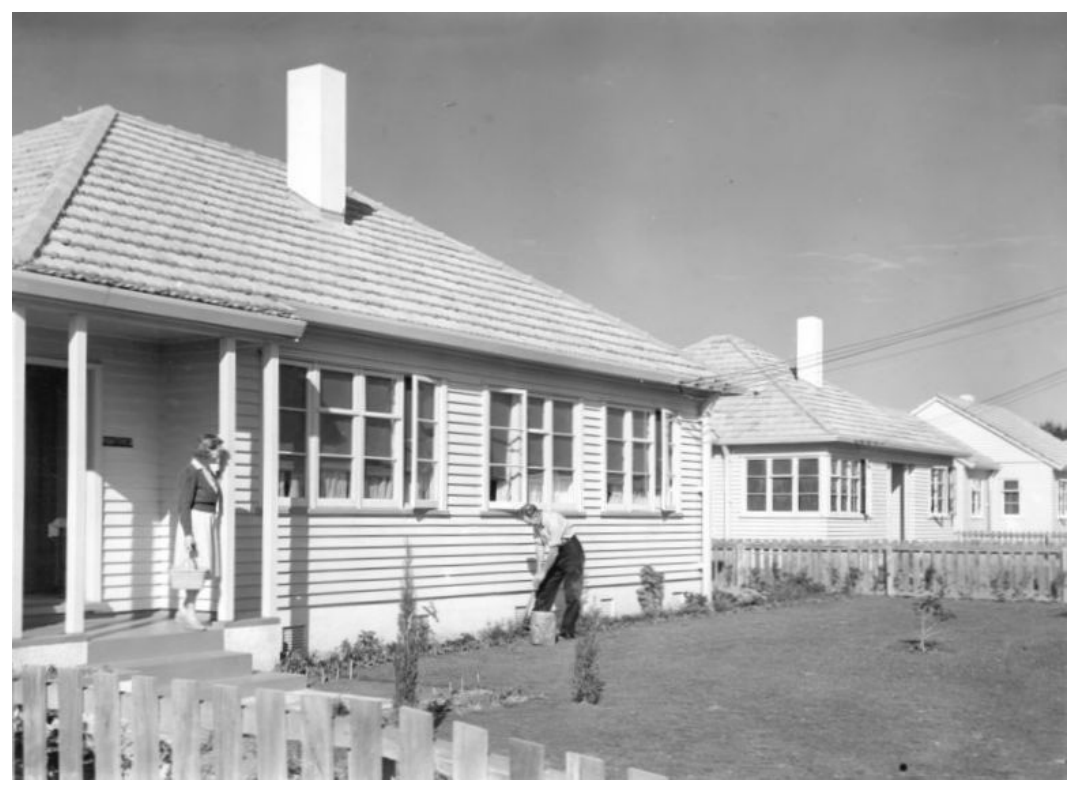

Figure 2.01

State housing by Unknown 


\section{Housing New Zealand homes}

New Zealand has had various forms of social housing since 1905 when Prime Minister Richard Seddon passed the Workers Dwellings Act. These have varied from detached single family homes (figure 2.01) to single bedroom apartments. In 2002 HNZ released the 'Pacific Housing Design Guide' (Faumuina \& Associates, 2002), and 'Ki te Hau Kainga: New perspective on Māori Housing solutions' (Hoskins, Te Nana,
Rhodes, Guy \& Sage, 2002). These two documents can be found within HNZ's 'Design Guideline' section of their website and show that HNZ acknowledges the need to design in culturally specific ways.

Social housing could potentially be manifested in limitless ways. To explore this potential therefore, three precedent reviews have been conducted. 

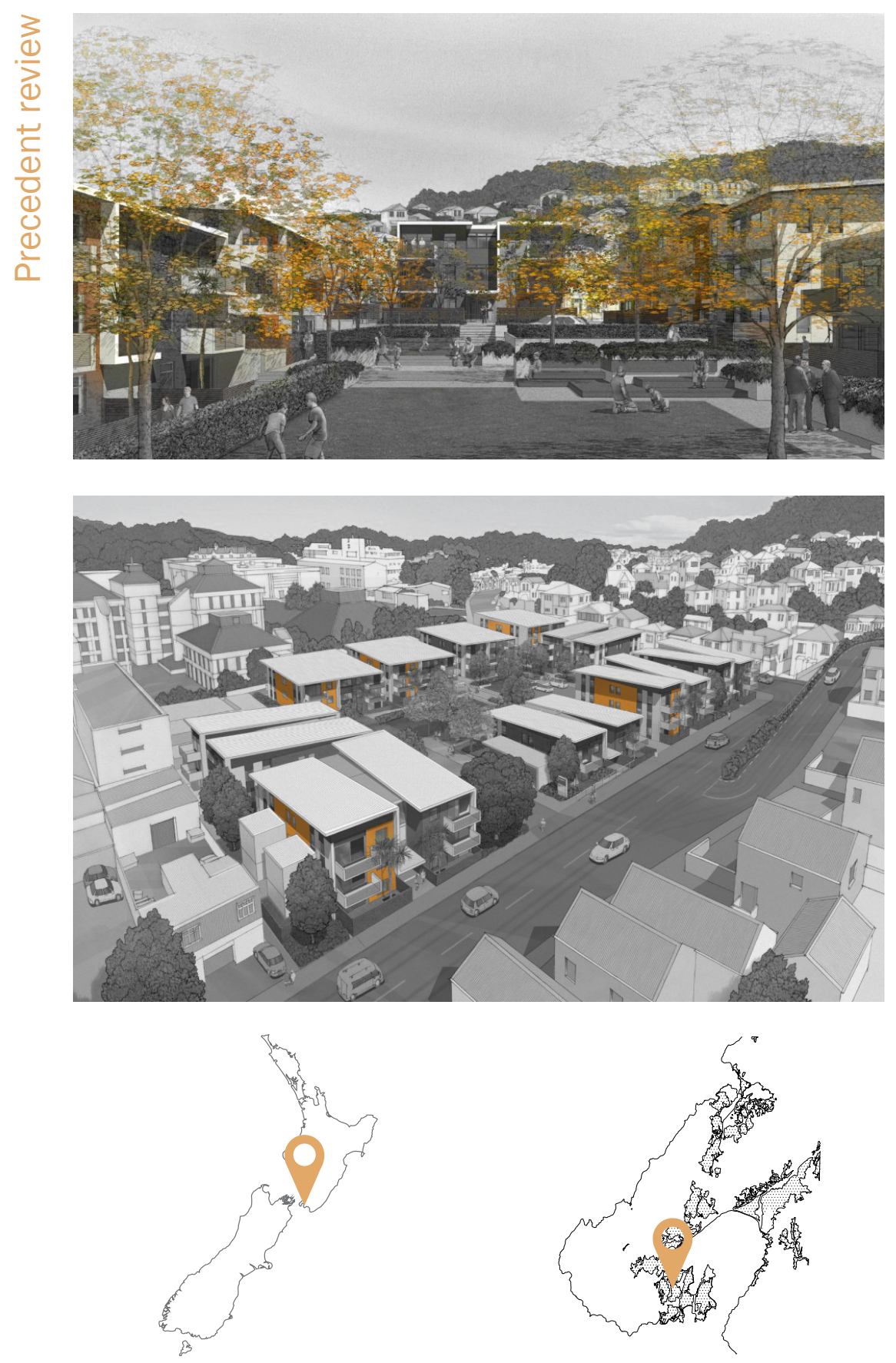

Figure 2.02

Arlington Apartments, architects drawing supplied to Fairfax 


\section{Arlington Apartments}

The Arlington Apartments redevelopment (figure 2.02) is part of Wellington City Council's (WCC) Housing Upgrade

Programme. The features of this redevelopment can be described as:

- a central courtyard,

- the buildings are designed so that the spatial configuration can be changed with minimal alterations. This is so that single bedroom apartments can be changed into multiple bedroom apartments and vice versa (Leviathan, 2015).
These features are interesting because:

- The central courtyard provides a semi-public space for the occupants and, filled with trees and plants becomes a lush space of prospect.

- designing an apartment block for future alteration could be indicative of the fact WCC does not know who the future inhabitants will be. 

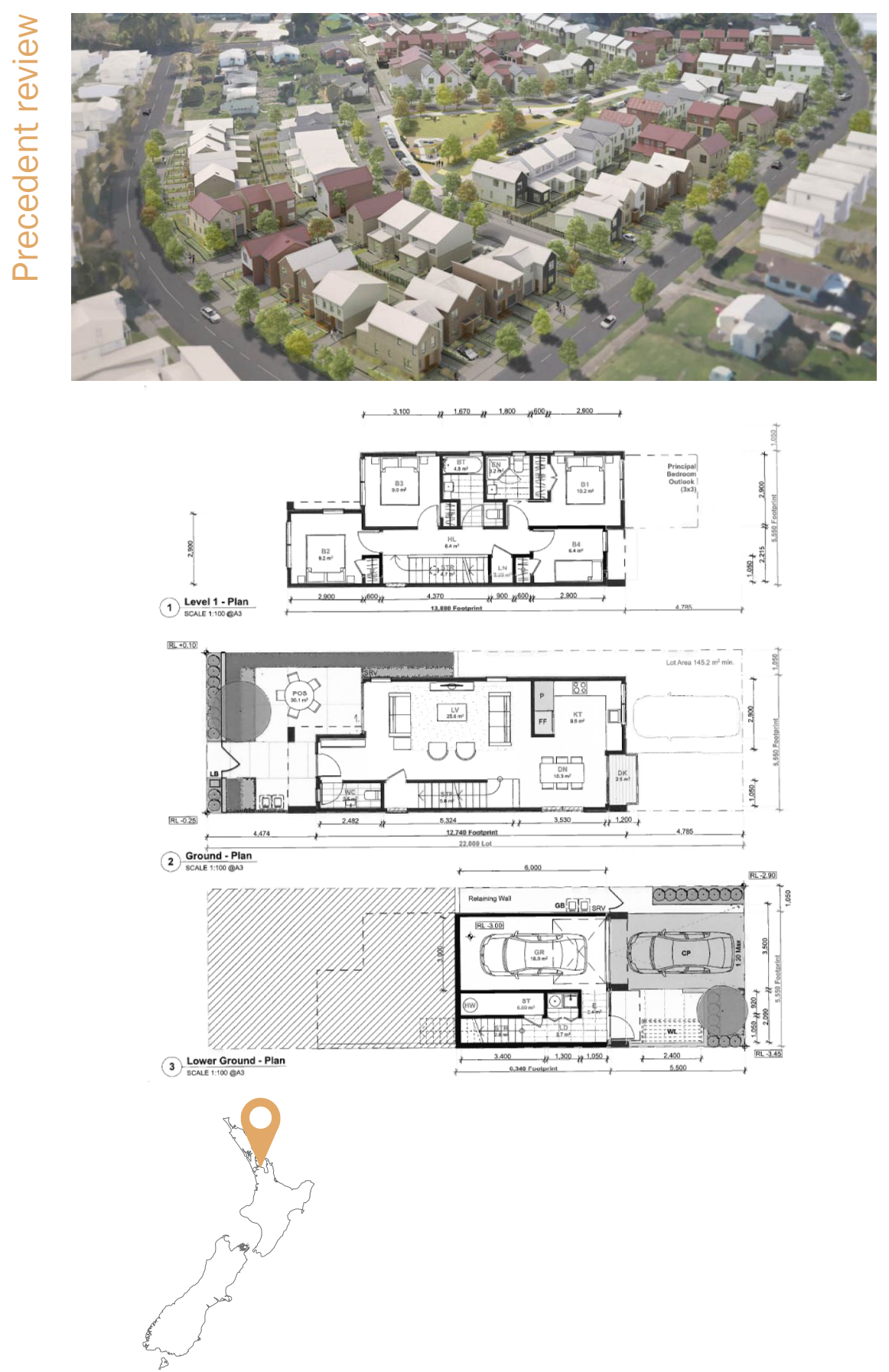

Figure 2.03 Tamaki Regeneration, architects impression from Jasmax and plans from TRC (2016). 


\section{Tāmaki Regeneration}

Tāmaki Regeneration Company (TRC) is an urban regeneration project east of Auckland city covering an area from Glenn Innes through to Panmure, which aims to "create a modern multi-cultural community' (Tāmaki Regeneration Company, 2016). Within the Tāmaki Reference Plan 'Economic development' is part of TRC's strategic objectives in which they aim to 'strengthen the local economy'.

TRC's plan is set within the district plan zoning regulations (Tāmaki Reference Plan, 2016:7). Auckland's Unitary Plan shows that most of this area is zoned as residential, with some existing pockets of business, showing a lack of planning for mixed-use building types in the area. This is a large-scale project and while much of the area is suburban and low density, it could explore a wider variety of building options such as dwellings with the potential for self-employment incorporated within them.
The features of the houses in TRC's development are: - large open living space which combines living, kitchen and dining, - generally two-storied, with bedrooms and other private areas upstairs, - street facing entrances.

These features are interesting because:

- TRC plans to create a modern multi-cultural community, but features such as a large opening living space will not suit all cultures, which makes the design assimilative.

- being two-storied and having private areas upstairs creates a threshold, which could be useful for various communities with different cultural and spatial values from a typical Pakeha household.

- With entrances facing the street, the houses could mainly be facing each other which does not provide many opportunities for prospect. 

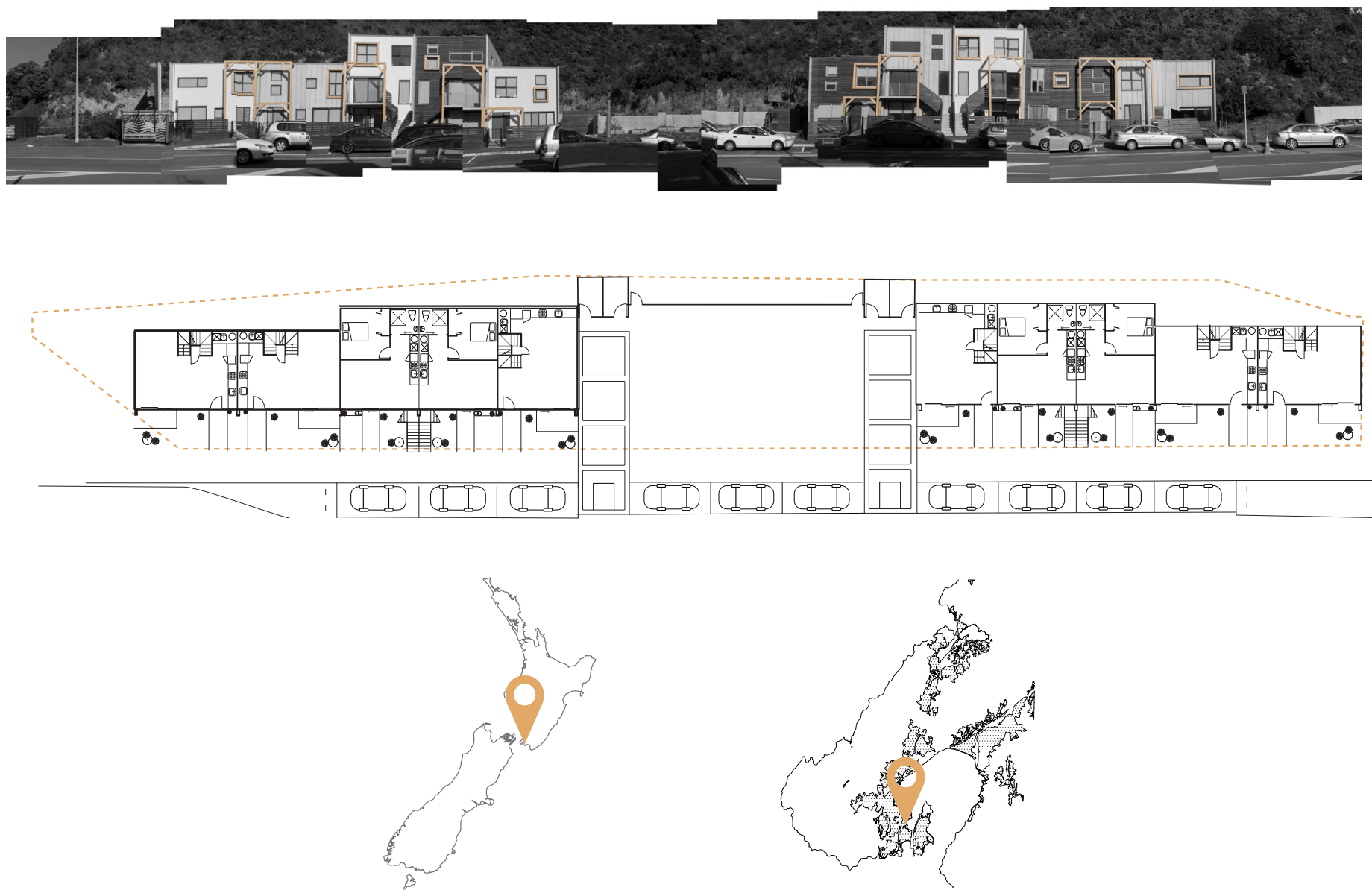

Figure 2.04 Te Aro Pā papakāinga 


\section{Te Aro Pā Papakāinga}

Te Aro Pā (figure 2.04) is Wellington's first papakāinga, a form of housing development which occurs on multipleowned Māori or ancestral land. At the papakāinga's opening ceremony, the Minister for Māori Development, Te Ururoa Flavell said: "It's for the betterment of our people, on our own land, in their own space, you can't get any better" (Te Tumu Paeroa, 2016).

This papakāinga is not only an affordable housing project, trustee Taku Parai has said: "The idea around developing such a building was to ensure that we built an edifice to our tupuna of Te Aro Pā and then to be able to share that with their descendants." (McLachlan, 2016).

The features of the papakāinga are:

- Dwellings are designed for families and the elderly, - central courtyard in-between the two housing blocks, this shared space contains: a lawn for children's play and large gatherings and a utility room which contain garden equipment and washing machines. The space is framed by a washing line to the rear, and communal vegetable gardens around the edges.

These features are interesting because:

- Designing dwellings for different demographics will create more variety, - the central courtyard can act in various ways to promote bonding social capital, which could help grow 'robust ethnic bonds' by acting as a shared space for a specific community. It can operate in a large sense as a gathering space, in a smaller sense as a shared garden or in a pragmatic sense as a place to do laundry, - as an edifice, the papakāinga has meaning for a specific community. 



\section{Reflection}

This section has investigated social housing to explore the possibility of social housing being designed to meet refugees' specific cultural and spatial needs. These projects demonstrate that there are many methods and ways in which social housing can be manifested. Social housing is no longer simply under the purview of the Government, it can now be a dynamic collaboration between Government and non-Government agencies and Trusts. The example of Arlington Apartments shows that social housing is dynamic and changing. More importantly, HNZ's design guides, TRC's aim to create a modern multi-cultural community and Te Aro Pā's aim to be an edifice for its tupuna and a gift to their descendants shows there is value in designing for culture.

However refugees' needs are more complex than simply designing for specific cultural and spatial needs. Sixty-three percent of refugees do not have enough money to meet their everyday needs. A building type, the shophouse, which combines dwelling and business could provide refugee populations with the potential opportunity to generate more income. 


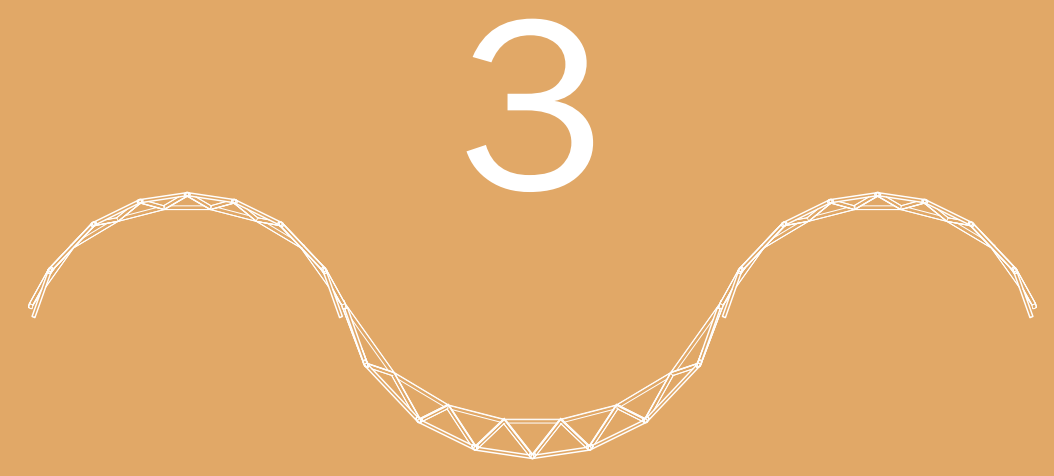




\section{Shop-house}

In this section a hybrid architectural type the shophouse is investigated. This is a simple building type that by combining business and dwelling offers the potential for self-employment from home. This section begins with a discussion by two prominent theorists, Frances Holliss and Howard Davis. After that, it investigates the verandah- a typical device found on the shophouse and then discusses the various ways in which this type can relate to the street. 

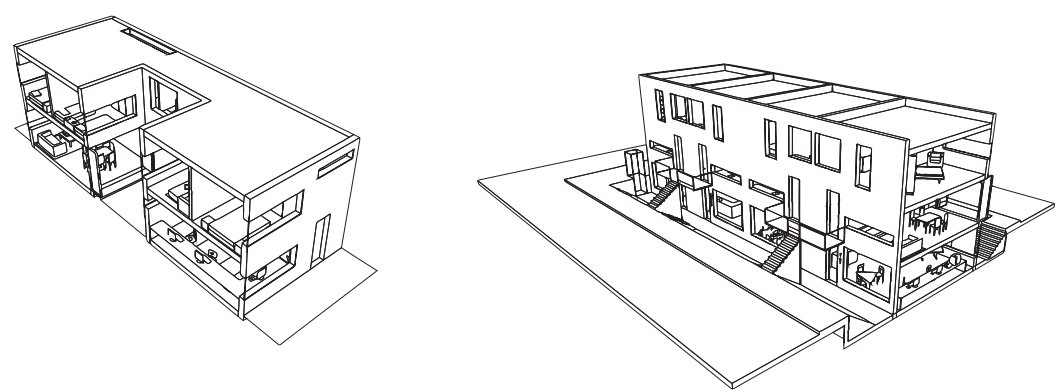

Figure 3.01

Two of Frances Holliss's designs from her 'pattern book'

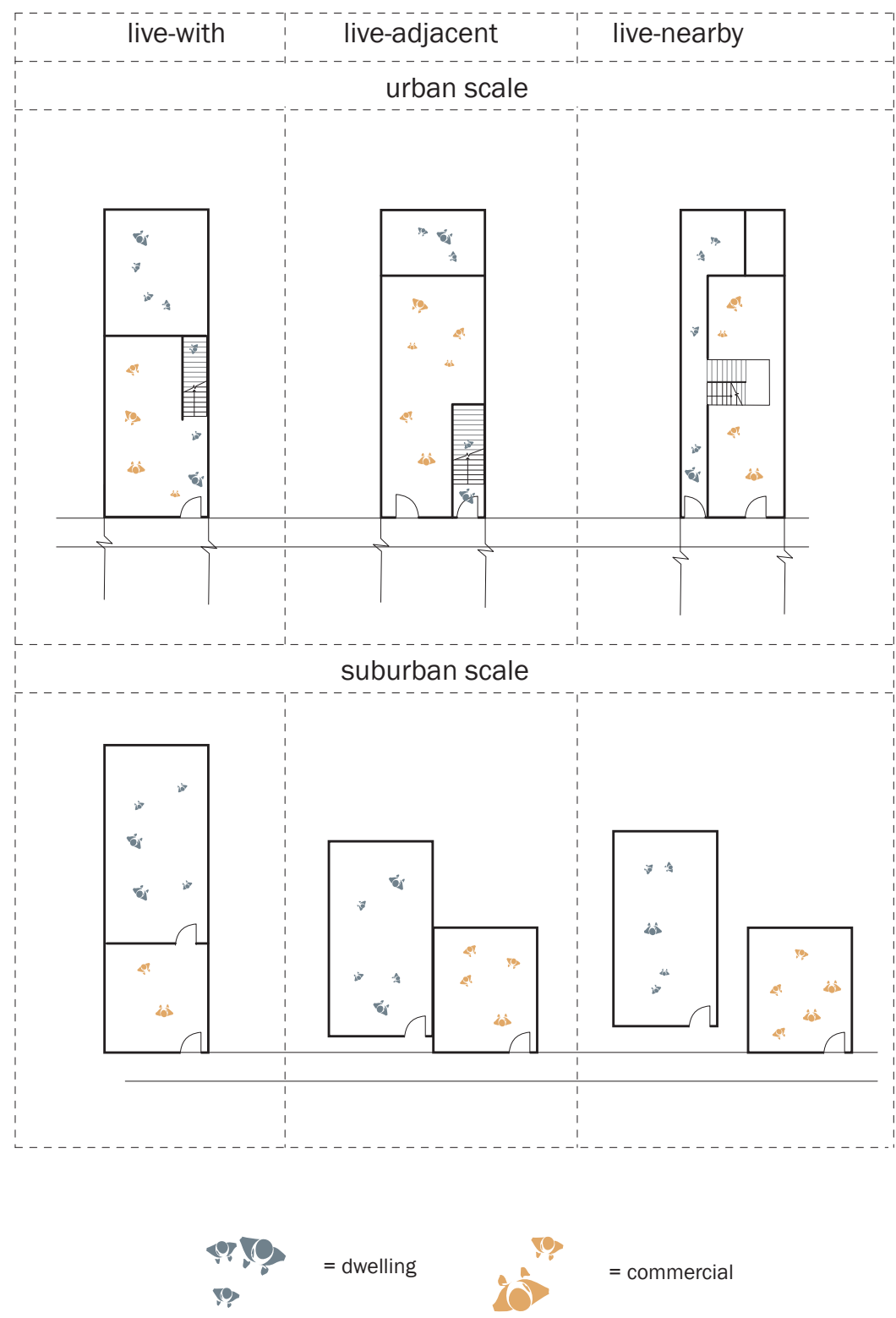

Figure 3.02 A diagram showing Holliss's shop-house categories which are used to investigate various methods that dwellings can accommodate selfemployment. 


\section{Frances Holliss}

"This relationship between public and private is one of the most critical in the design of the workhome." - (Holliss, www. theworkhome.com)

Frances Holliss is an Emeritus Reader in Architecture at the London Metropolitan University, who defines specific noncontextual categories to discuss and analyse the shop-house.

Holliss's examinations provide a methodology which can be used to gain a basis understanding of possible iterations of this type. Her categories: 'live-with', 'live-adjacent' and 'live-nearby' provide a simple tool in which to examine design experiments. 


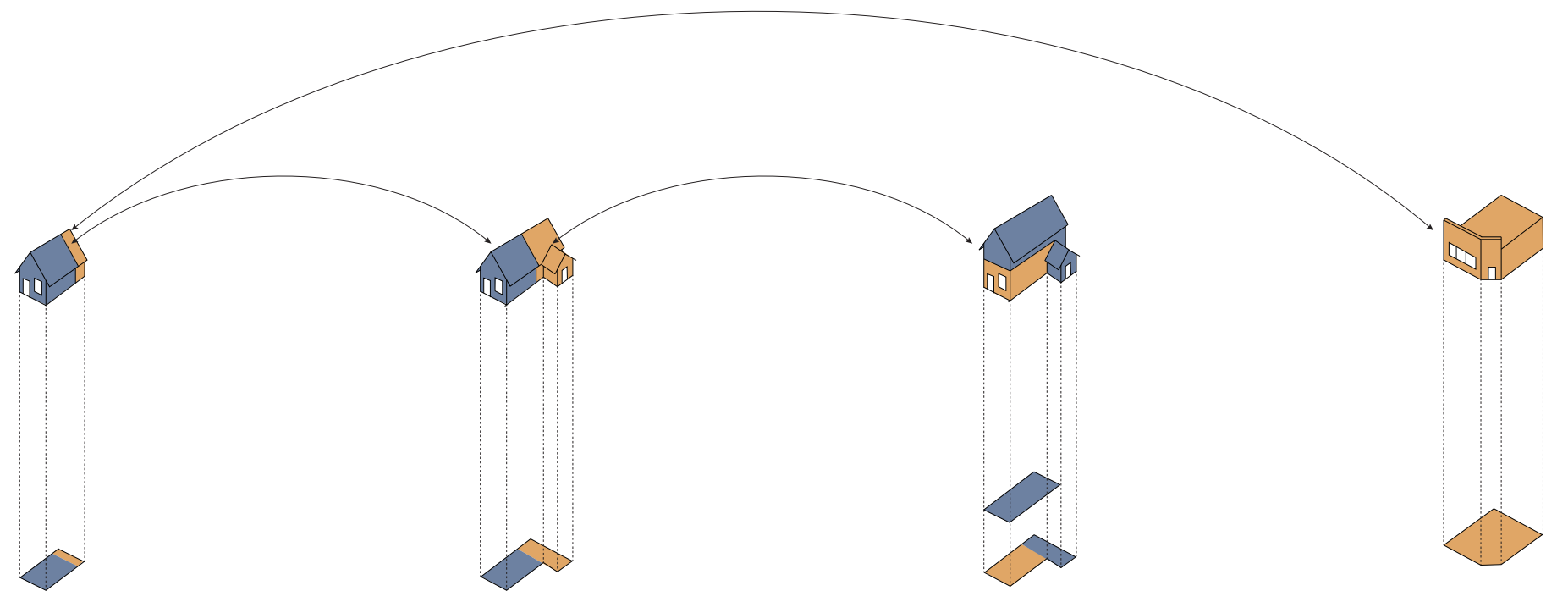

Figure 3.03 A diagram showing some possible methods of potential evolution of a dwelling which provides the ability for self-employment. This was informed by the hybridity discussed by Davis (2012). 


\section{Howard Davis}

Howard Davis states that the shop-house 'is the spatial manifestation in one structure of two common economic conditions of the city: it puts commerce on the street, and it lets people live where they work.' (Davis, 2012:12). This pragmatic statement provides a description of the simple functional value in this type and it explains why the shophouse is a fundamental feature of an urban landscape. Davis's investigation travels across countries, examining the shophouse both as a manifestation of a cultural object, and manifesting from these simple economic conditions.

Davis's conclusion in this investigation into the shophouse is that this is a building type which enriches its surroundings:

- it provides an economic foothold for people of all economic means, by providing the opportunity for self-employment only defined by self-determination (Davis, 2012:214)

- it is part of the "fine-grained neighborhood' (Davis, 2012:218), which means that it can provide diversity and connectivity, which Davis regards as a vibrant aspect of urban life (Davis, 2012:18). - it is a hybrid type, able to adapt and manifest in limitless ways to meet basic economic needs (Davis, 2012), which has meant that the shop-house type can adapt itself to meet any specific cultural or spatial needs (Davis, 2012:12) 

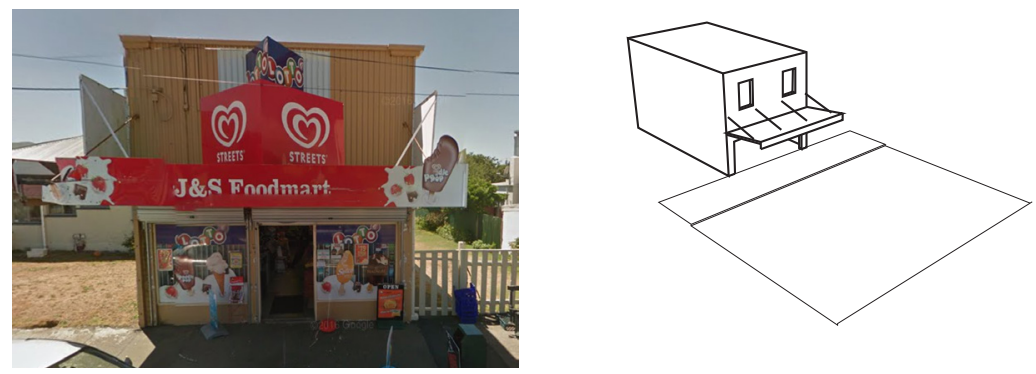

2
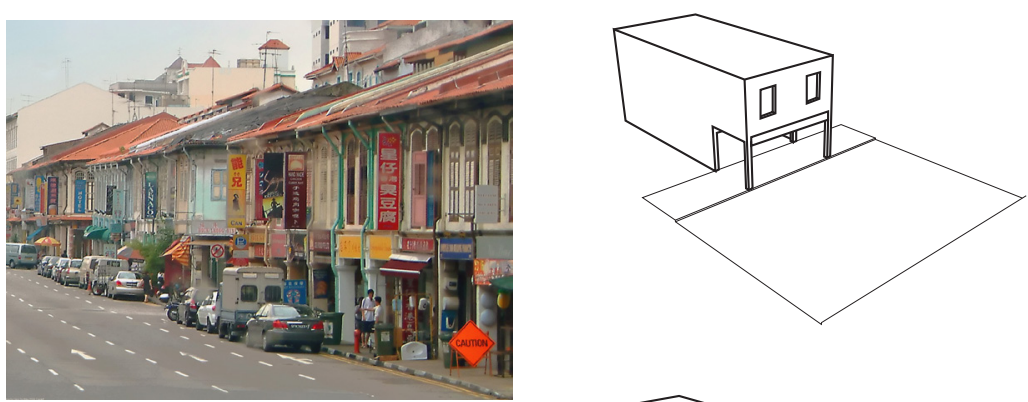

3
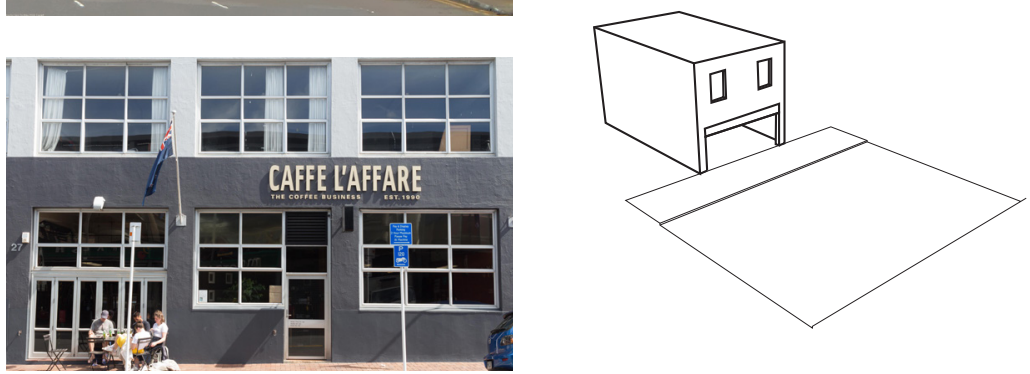

4
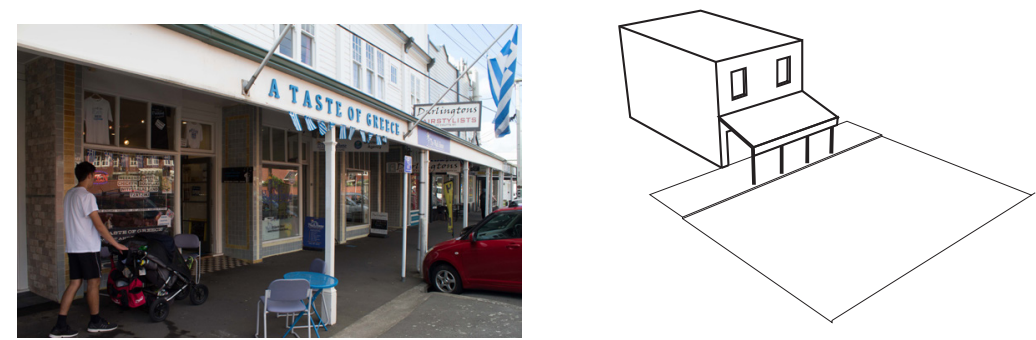

5
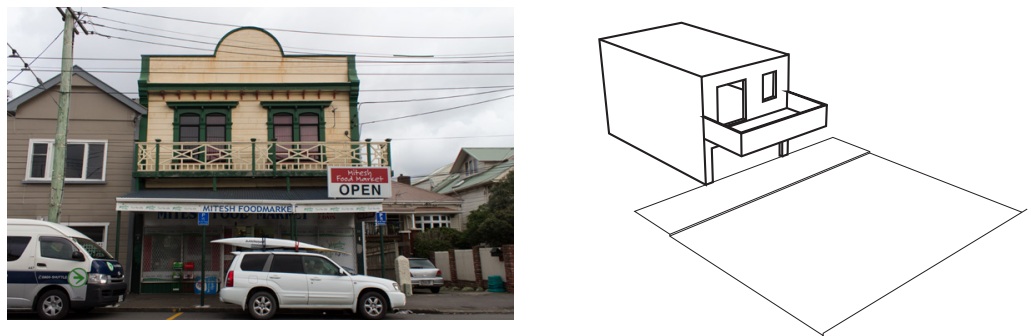

6
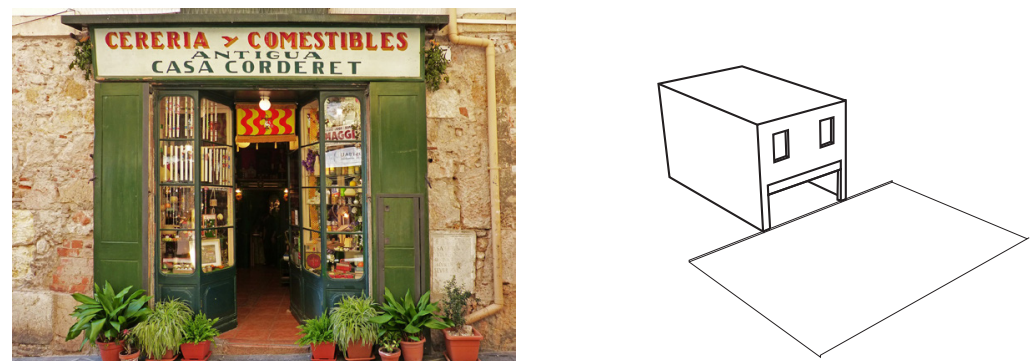

Figure $3.04 \quad$ A diagram showing a variety of shop-house to street relationships with the device of a veranda 1/ J\&S Foodmart in Petone

2/ Shophouses in Singapore circa 2006, photo by Calvin Teo

3/Caffe L'Affaire in Central Wellington

4/Coutts street shops in Kilburnie

5/Mitesh Foodmarket in Mount Victoria

6/ Traditional Chandlery Shop in Mexico, photo by unknown 


\section{The veranda}

The veranda (figure 3.04) is an architecture device which is common throughout Asia and New Zealand. In 1823, Sir Stamford Raffles created a set of building codes in Singapore which defined what is now known as the Singapore shophouse (figure 3.04, number 2). Part of this building code was what is known as the " 5 -foot way' (Davis, 2012: 31) which is comparable to the verandas on many shop-houses in New Zealand. In the formation of these building codes, Raffles was strongly influenced by buildings in Jakarta which were a combination of Dutch and Indonesian styles (Davis, 2012:30). The Singapore shop- house is a truly hybrid type and can still be seen in Singapore today.

This device acts as:

- a liminal zone which draws customers in the shop-house, - a privacy barrier between the street and the dwelling

This is interesting because: - the liminal zone creates a threshold which is both welcoming to the customers and indicative of where the entrance is

- the functions are kept visually separate in a simple way by protecting the dwelling from street view 


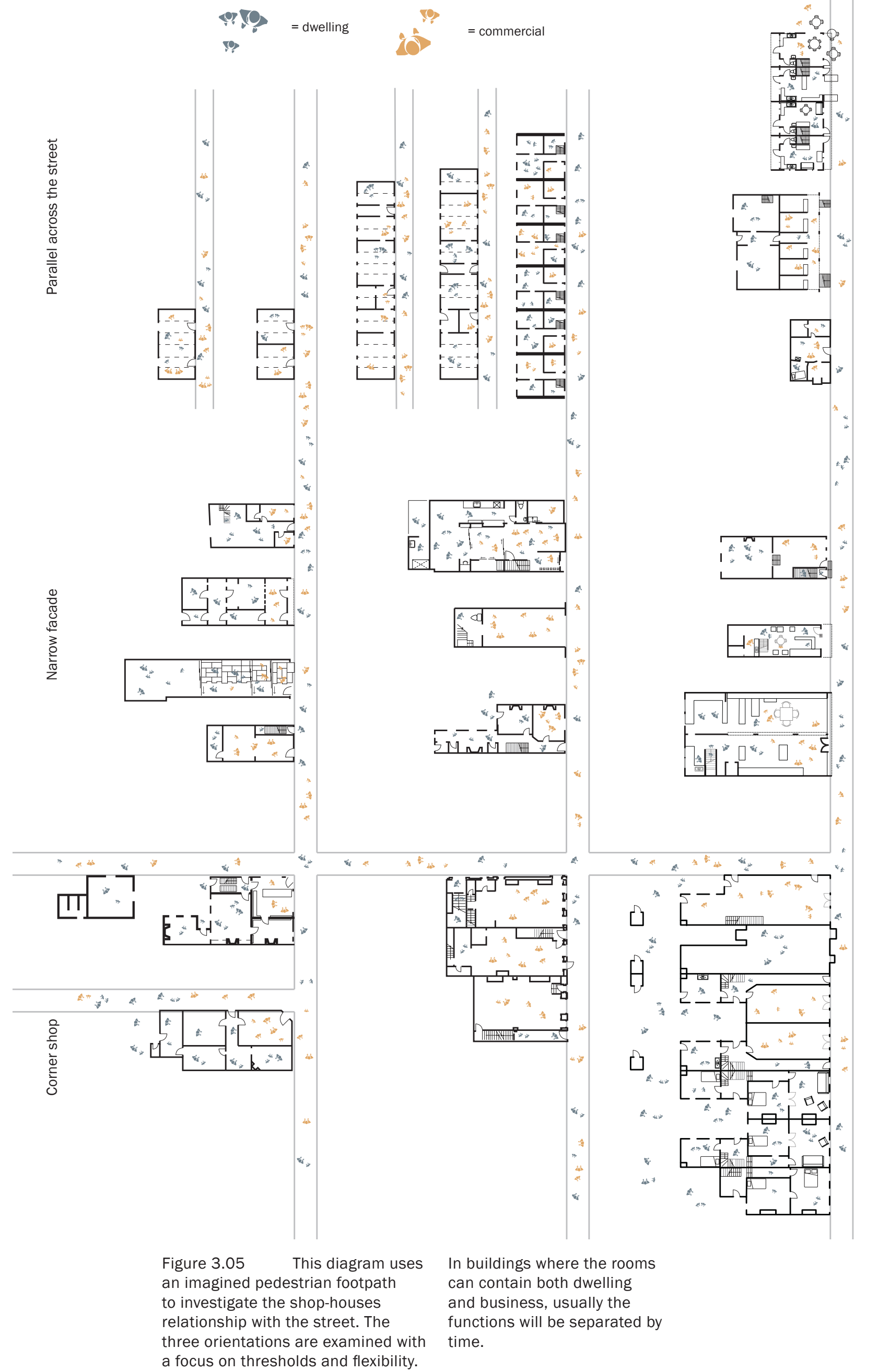




\section{Street orientation}

The shop-house can be orientated towards the street in two main ways (figure 3.05): either a narrow façade which has the commercial function on the street and the dwelling behind or; with the building spread parallel across the street. As a type that contains a commercial function, this orientation can be influenced by the surrounding building density. This is because of the economic value of having as many shop-houses as possible on commercial streets (Davis, 2012:31).

Typically, in New Zealand, the shop-house will be orientated with a narrow façade across a main street. The features of this type are:

- dwelling entrance hidden behind the house or, on a minor road, - shop front is flush with a footpath

These features are interesting because:

- maintaining privacy for the dwelling entrance is important so that customers don't use it, - connecting flush with the street provides a high level of visibility. But this area between the shop and the street could potentially provide opportunities for architectural investigation. 


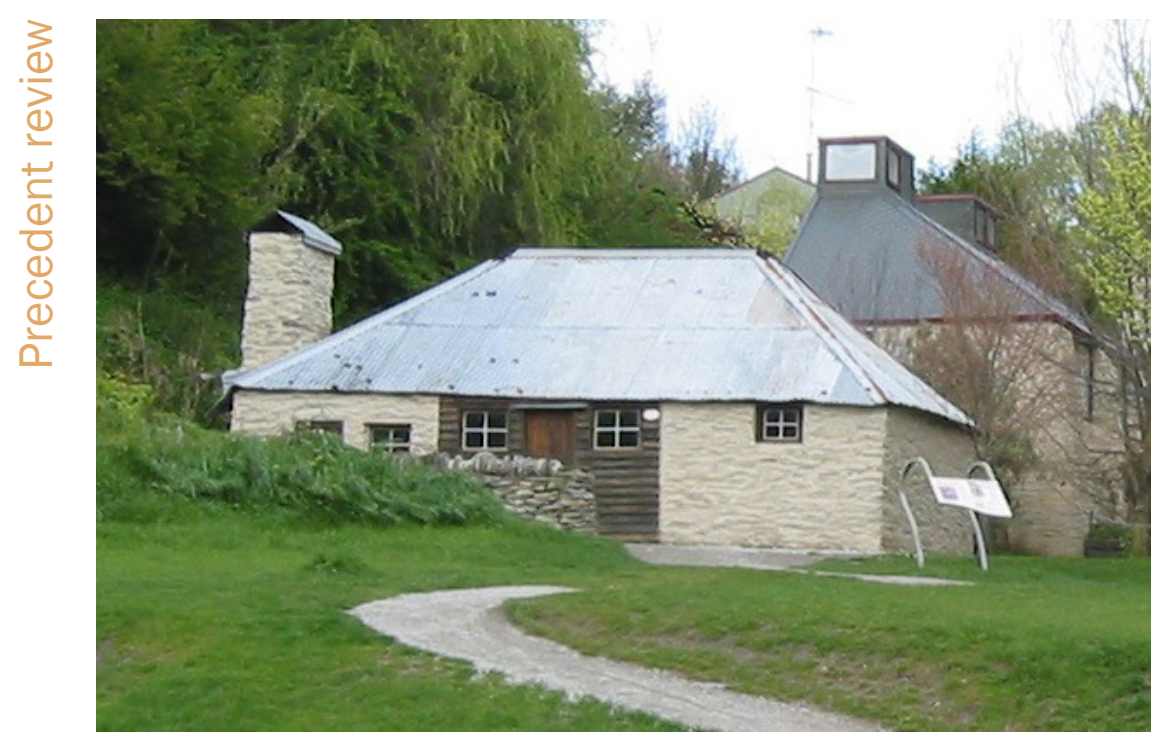

Figure 3.06 The entranceway of Ah Lum's shop-house. This image shows the scale of the building.

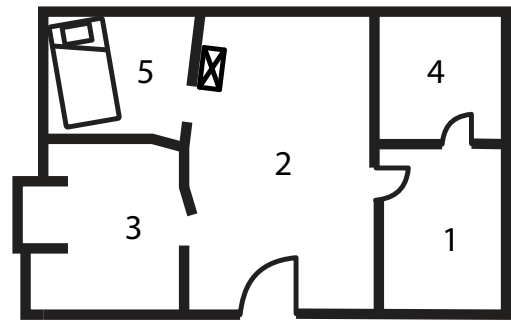

$$
\begin{array}{ll}
1=\text { shop } & 4=\text { storage } \\
2=\text { liminal: hall } & 5=\text { bedroom } \\
3=\text { kitchen } &
\end{array}
$$

Figure 3.07 A plan of Ah Lum's dwelling showing the wide hall which acted as a liminal zone to mediate between various functions

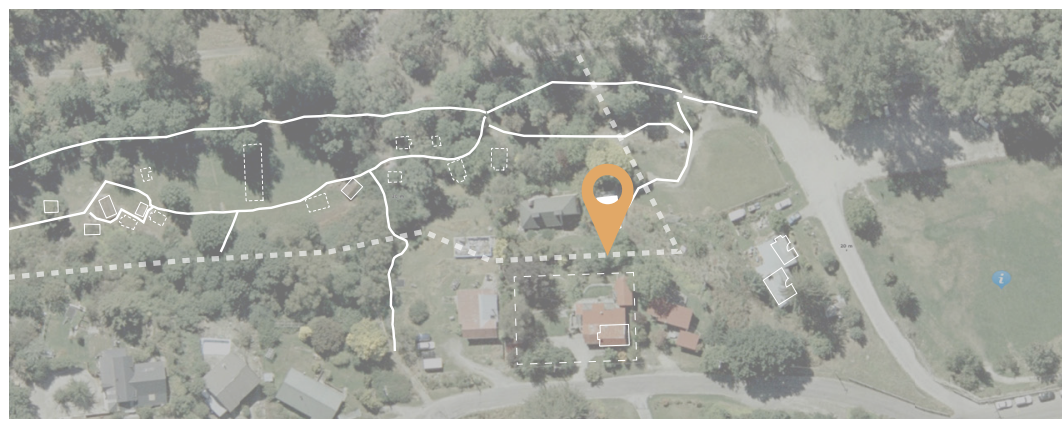

Figure 3.08

A map showing the location of the dwelling 


\section{Ah Lum's house}

A notable historic example of a shop-house in New Zealand is Ah Lum's House (figure 3.06) in the 19th Century gold mining community of Arrowtown.

The features of this small building are:

- it was a highly flexible building, from which Ah Lum ran a grocery, bank, and community center

- a wide central hall acted as a liminal zone between these functions

- it sat on the boundary between the Chinese and Pākehā populations (figure 3.08 ), and did business with both
These features are interesting because:

- for such a small building to contain so many functions, it demonstrates there was a specific need for these functions in this community. This could also show the potential value in combining business, commercial and dwelling for a specific cultural context.

- the central hall shows that the liminal zone does not need to be outside the house

- the location means this was an early and clear example of a shop-house being a node within a community and increasing intercultural contact. 

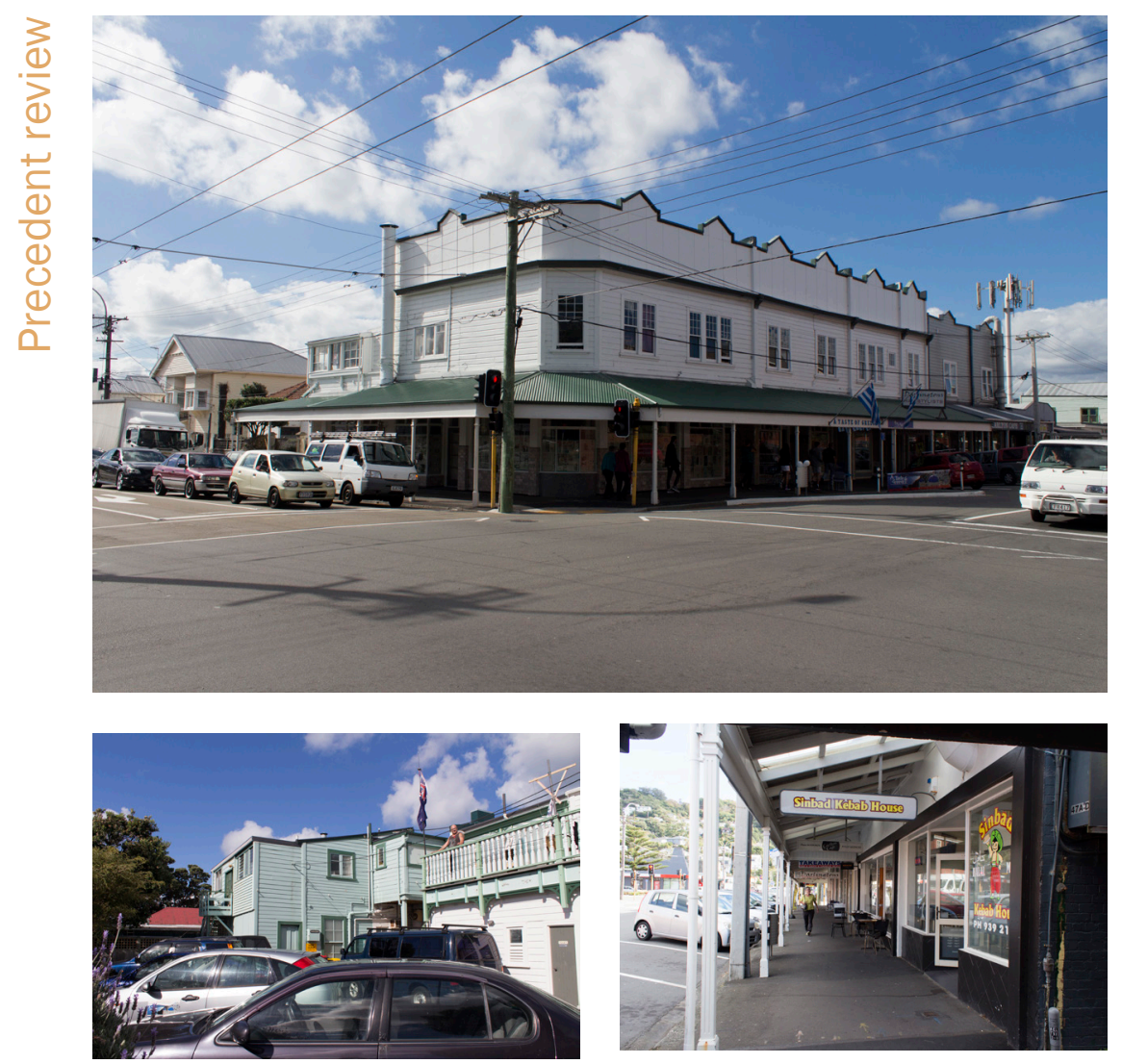

Figure $3.09 \quad$ Photos (clockwise from top) showing the buildings relationship to the street, the '5-foot way' and the dwelling entrances and private deck.
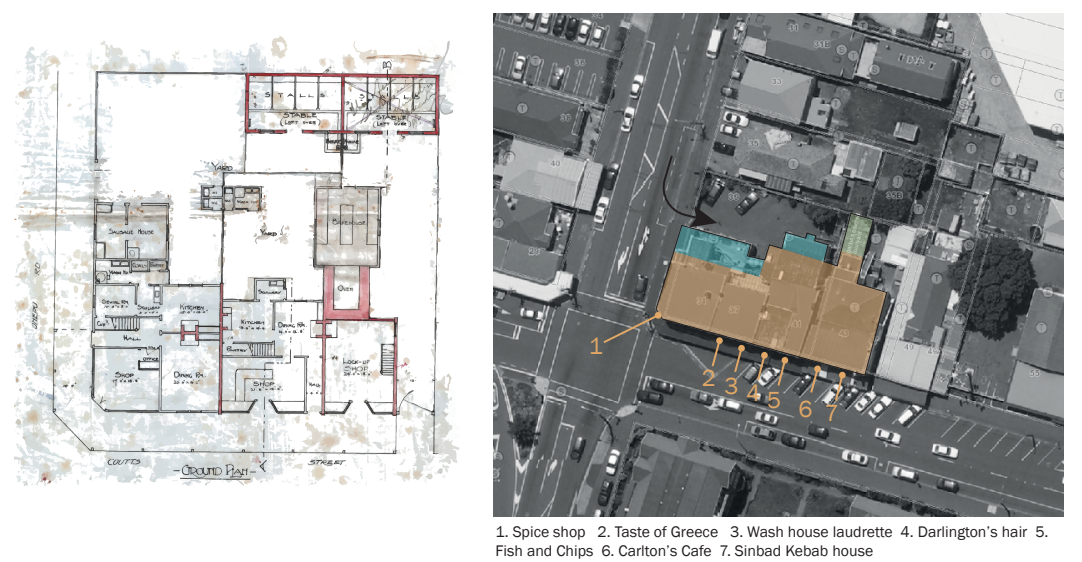

Figure 3.10

The an showing the original building plan and the building as it is today. 


\section{Coutts Street Shop-houses}

Originally built in 1910 in Coutts Street (figure $3.09 \& 3.10$ ), Kilbirnie this shop-house type in Coutts Street stands the test of time.

The features of this building are: - it was originally built to include three shops, a bakery, and stables on the ground-floor at street level. Today this building has seven ground-floor shops/ businesses.

- dwellings are on the first floor raised above the commercial functions with north facing decks. They are accessed through a gateway on a minor street.

- the basic layout of the building has not changed much in 100 years

These features are interesting because:

- this commercial growth shows both the value of the shop-house type and a potential method for spatial evolution/growth. - the dwellings have outdoor space, while also maintaining privacy from the businesses - this shows the potential adaptability of this type. 



\section{Reflection}

Arising from common economic conditions of the city, the shop-house is a versatile type which has existed in different parts of the world and over different eras. While Holliss's work on shop-houses provides solid categories from which to examine design iterations, Davis's work provides an understanding that by meeting fundamental economic needs in a basic way, the shop-house is a valuable type which is adaptable to meet specific cultural and spatial needs and can provide an economic foothold for the self-determined.

The Veranda is a useful architectural device which when perceived as a liminal zone can act to both bring customers in and provide privacy to the dwelling. Street orientation defines how the shop is connected to the street and could provide a potential site of architectural investigation. Ah Lum's house proves that a building which provides commercial and dwelling functions can increase intercultural contact and the Coutts Street shops show the potential adaptability of the shophouse type.

This thesis seeks to investigate the long-term resettlement needs of refugees through the lens of selective acculturation by using the shop-house as an architectural device. To both integrate and provide a potential opportunity for self-employment for a refugee population, a target group is needed to investigate a design which would meet the specific economic, cultural and spatial needs of a refugee group.

The largest, and most permanent refugee group in New Zealand is the mixed ethnic groups from Myanmar (Burma). 


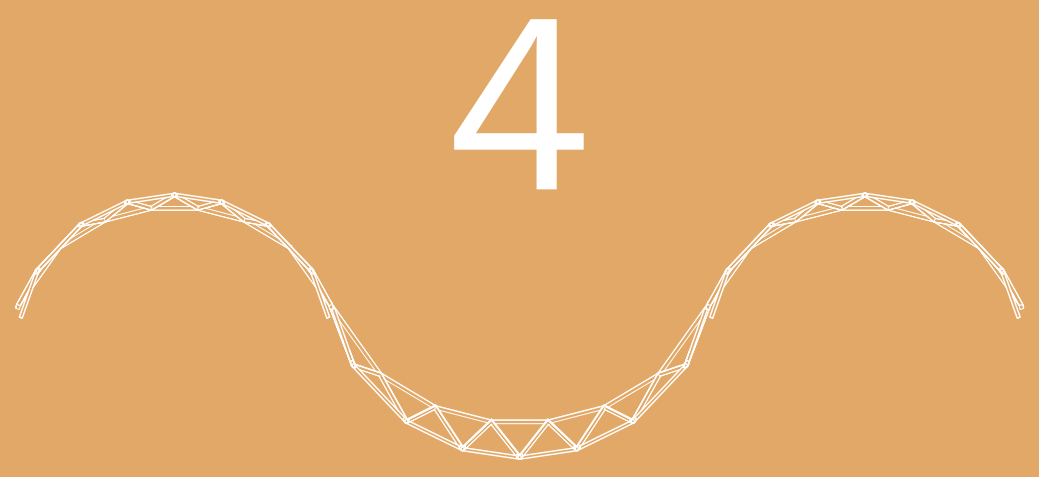




\section{Myanmar Ethnics (Burma)}

This section begins with a general discussion about the Myanmar Ethnics group in New Zealand. To discover the specific economic, cultural and spatial needs of this group, an interview process is conducted. The methodology of this process is described, then an investigation into vernacular architecture in Myanmar is carried out. Specific information gained in the interview process is examined and a precedent review is conducted to fill in missing gaps in the information. 

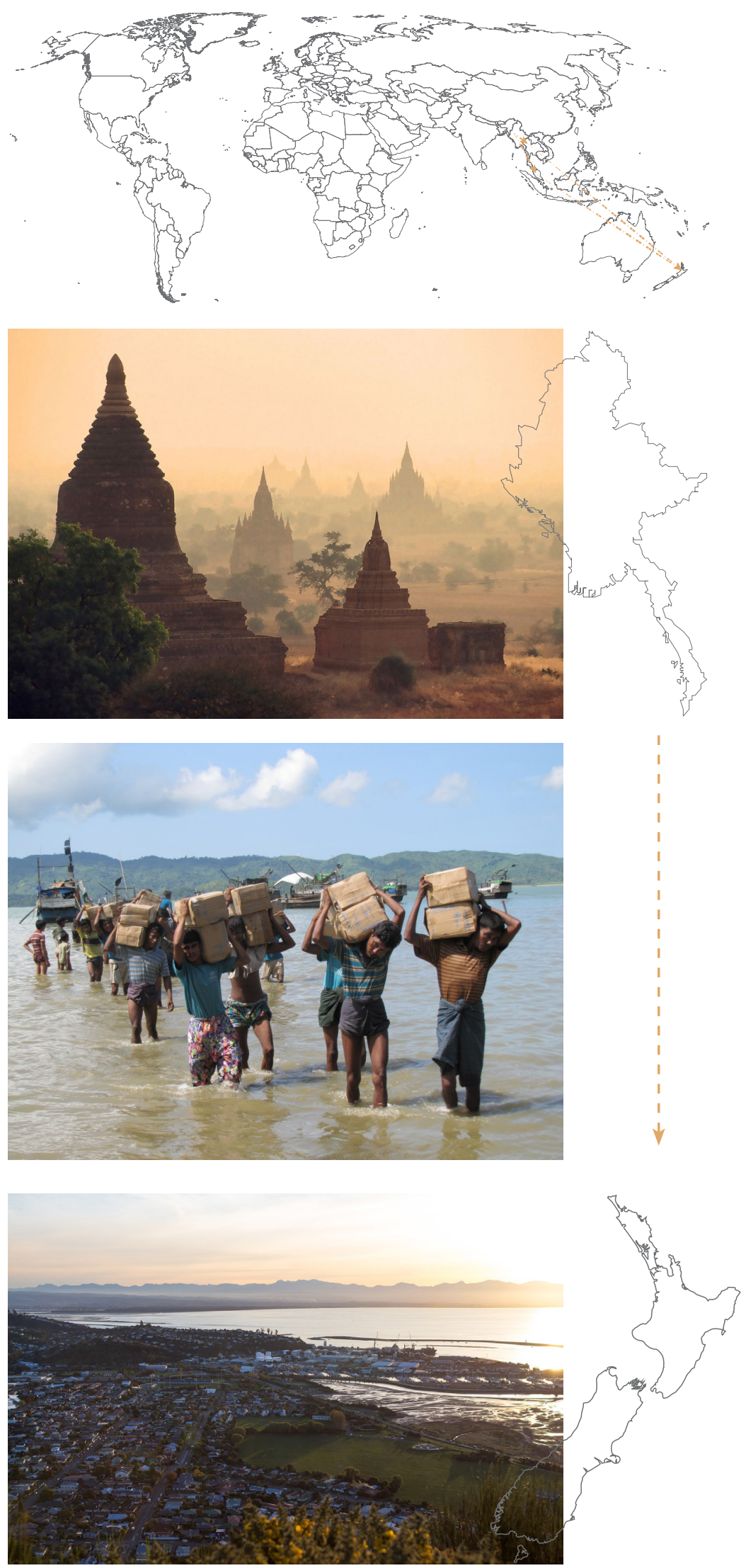

Figure 4.01 A collaged image showing a visual journey from Myanmar to New Zealand, photos by Nick Kenrick and Mathias Eick. 


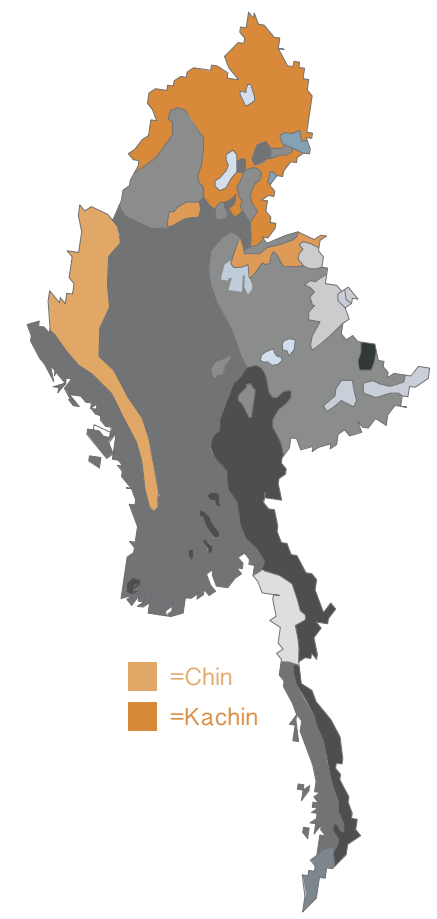

Figure 4.02

an ethnolinguistic

map showing

approximate

geographic

locations of

Myanmar

Ethnics. This

map is presented

to show the

diversity present

in the people of

Myanmar, and

also the vast

difference - in both

physical distance

and environment

between two

common Myanmar

Ethnic Groups in

New Zealand.

\section{The People}

"Many of the women expressed pride in their culture and said how keen they were to share it with the host community. Although many commented on the constraints of unemployment and lack of finance, they also said they had a lot to contribute in terms of the wealth of their culture - the sense of helping others, their cooking, their distinctive traditional clothing and rich handicraft traditions, and the many distinct ethnic cultures of Burma." (Kamri-McGurk, 2012:100)

This statement from KamriMcGurk's thesis shows that, while there are constraints, the Myanmar community are highly

motivated to share their culture with the wider New Zealand community, particularly in relation to food. As a country, Myanmar is a diverse country, made up of multiple ethnicities, cultures and languages (figure 4.02). In New Zealand, the Myanmar Ethnics Group represents this diversity and operates under the New Zealand Myanmar Ethnics Council Inc (NZMEC). The NZMEC is a community organization which supports its members through practical services such as advocacy, translation and community events. This is a motivated, organized and highly capable community who have the potential to further contribute to New Zealand. 
Called Red Cross, told not relevant to my studies - refugees too new, told to get in touch with Changemakers.

Left a message (phone)-at Changemakers. Chanqemakers, left my details. They Visited Changemakers, left my details. They back to me.

Emailed Newtown Cultural Community Centre (NCCC).

NCCC replied, gave me details.

Emailed

Emailed at English Language Partners

Wellirigton.

is

Me with Colombia) and discussed shops

thouses etc.

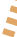

called, discussion about my project and my motivations. Given XXi :ails.

Caled XX and arranged to meet on 12/4/16

couldn't make it.

replied. Gave me details of $X$ (Changemakers.)

Meeting with Myanmar Ethnics Groups families postponed.

Went to Maha Thingjan (Myanmar's New Year festival). Introduced myself in person to XXX.<smiles></smiles>
Called and arranged to meet on 20/4/16.
$19 / 4 / 10$.
indefinitely cancelled meeting me (they're too busy).

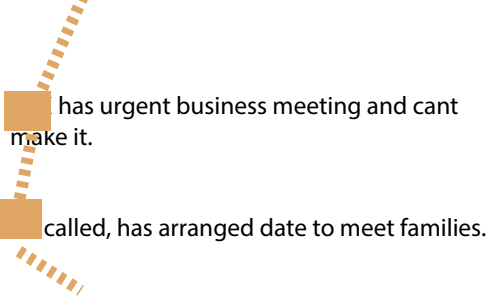

Meeting and chatting with families.

$$
5
$$

Formal interview
Changemakers

Myanmar Ethnics Groups

ELPNZ

Colombia 


\section{Interview Process}

To conduct a formal interview process, the first step taken was to establish contact with a member of the Myanmar Ethnics in Wellington (figure 4.03). Once this contact was found, a request was made to be connected with suitable interviewees - community members who would be interested in starting a business from their home.

The next stage was to gain ethics approval, which was granted on 13th July 2016. After this the formal interview was conducted with a set of open questions (see Appendix A). The questions were a guideline and information was gathered through a conversational process.
The refugees' needs discovered in this interview process are examined and used to guide an iterative design process (Sections 6-8). The main feature that the interviewees and other community members wanted was specific spatial programming of the house. This is discussed in detail in this section, in "spatial programming'.

At various stages throughout the process, discussions were conducted with an available community member to see if important details were missing, or misinterpreted.

The first step was to contrast this primary source information with secondary source information (see page 59, figures 4.06 and 4.07). 

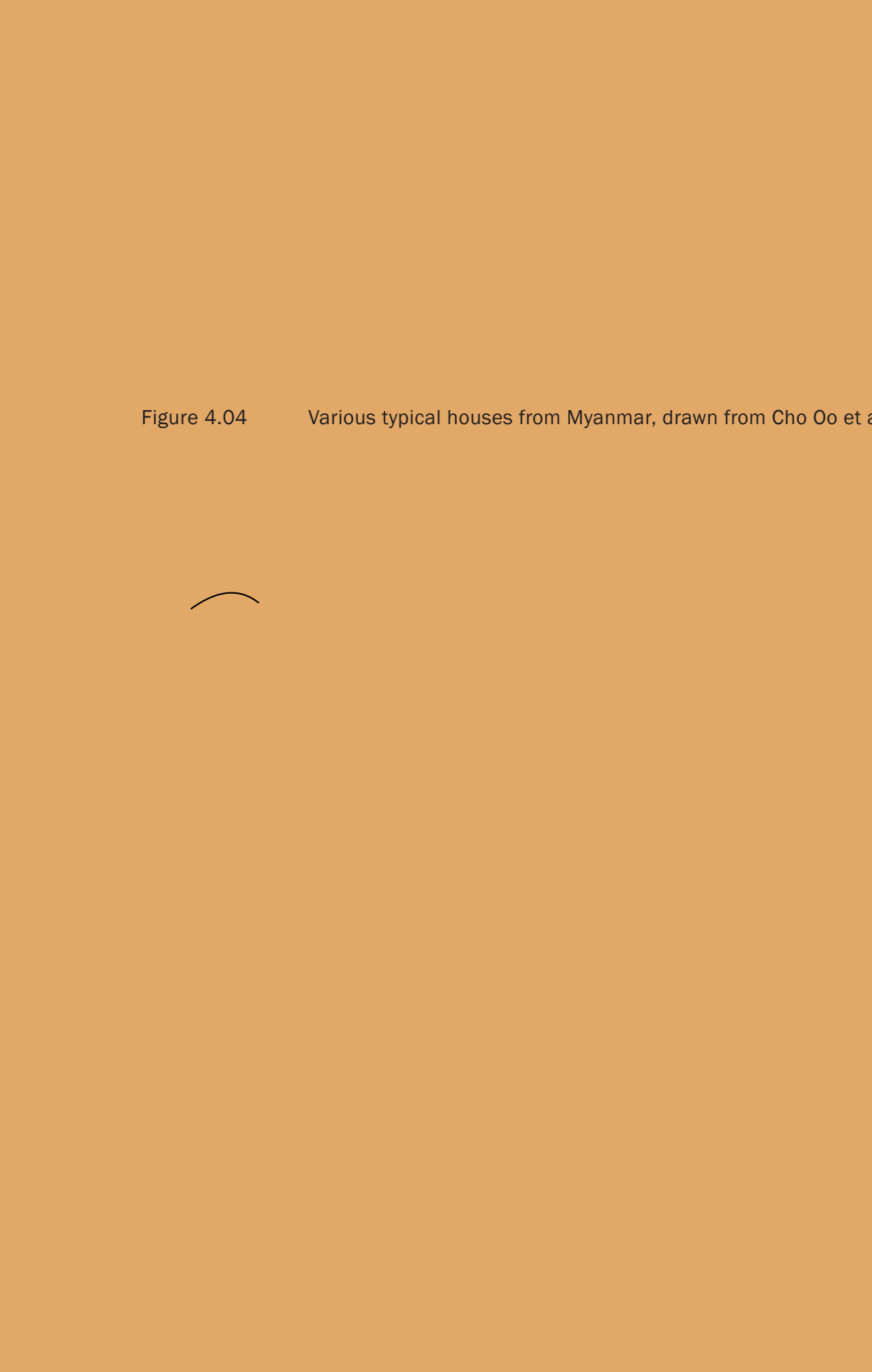


\section{The Vernacular dwelling}

This diagram (figure 4.04 \& $4.05)$ visually shows aspects of the investigative process into vernacular architecture in Myanmar. This information is mostly drawn from the texts of Thanegi \& Broman (2005), Invernizzi \& Falconer (1998) and Oo et al (2003). Essential information gained through this process is:

- the importance of spatialisation of tradition, ritual and hospitality (Thanegi 2005:p89-93)

- the dwelling is raised above the ground on posts, which is mainly an environmental design feature. This keeps the dwelling cool, by allowing breeze to pass under. It also prevents flooding, as many houses in Myanmar are built near waterways and on floodplains. The area under the house can be used as a shady spot to sit, and a place to keep animals. (Invernizzi \& Falconer, 1998: 60)

- As the dwelling is raised, stairs must be climbed to enter the dwelling. These lead to a veranda, which can be open or under the dwelling's roof. (Thanegi 2005:92) The stairs and veranda act as a liminal zone before entering the house. This means that the veranda becomes a meeting place where guests are greeted, and the moment between the dwelling the exterior.

- As a place where guests are greeted, on the veranda there is a pot of cool water for visitors and an area to take off shoes. The veranda can be known as the 'show-watching chamber' because it looks out over public space (Thanegi 2005:92).

- To enter the house, there are large folding doors which open onto the veranda. These doors open up the front wall of the house into a large living space, which means the living space can be extended out to the veranda to accommodate guests (Thanegi 2005:93).

- mealtimes are a social time to be spent with friends and family and a circular dining table is rolled out at mealtimes (Thanegi 2005:91). This is considered to be an open and social way to eat.

Other interesting features of the dwellings noted are:

- the woven bamboo patterns of the walls,

- the way in which light filters into the airy interiors, - the living room operating as a large central space and an entry point into the house 

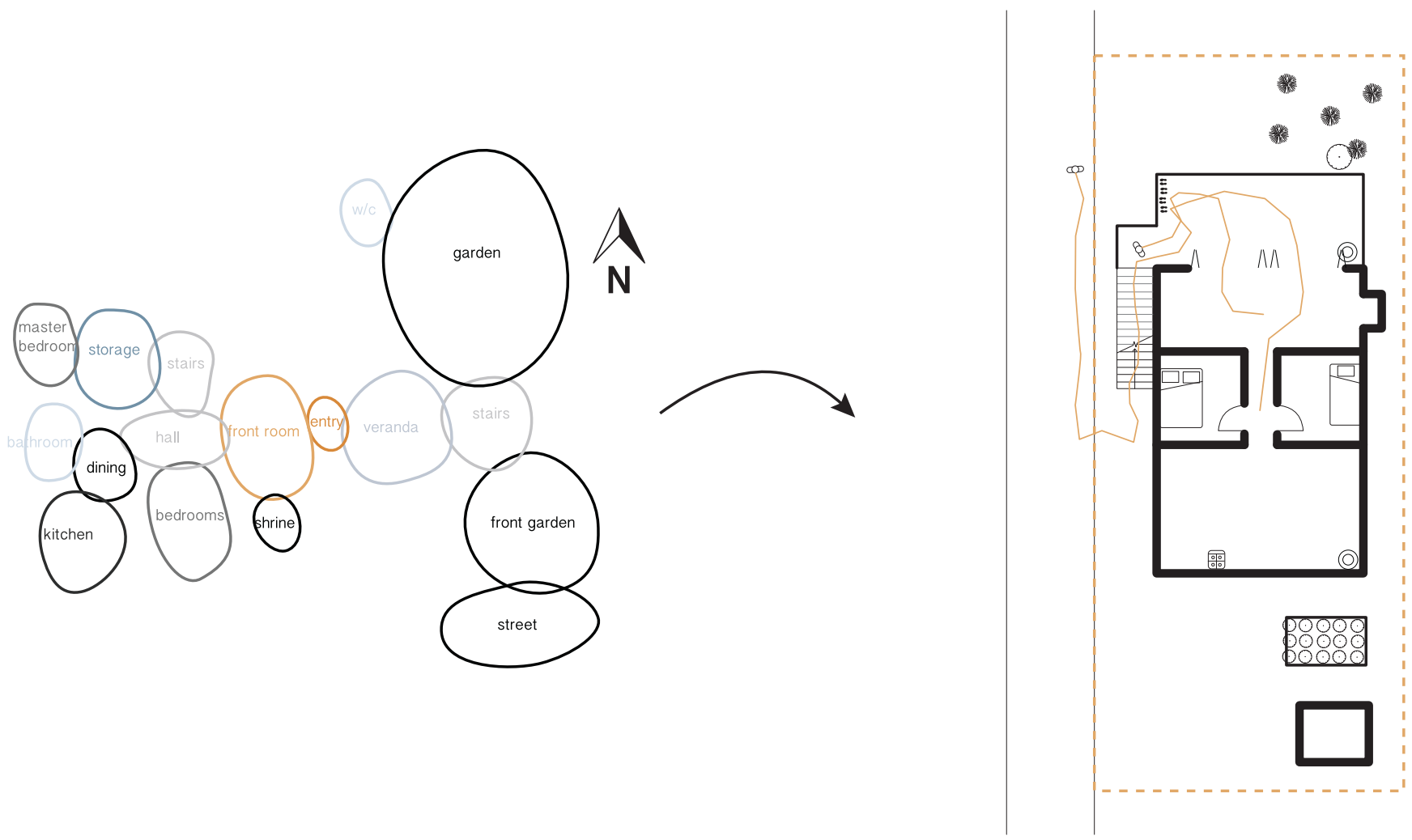

Figure 4.06 Spatial programming diagram drawn from secondary

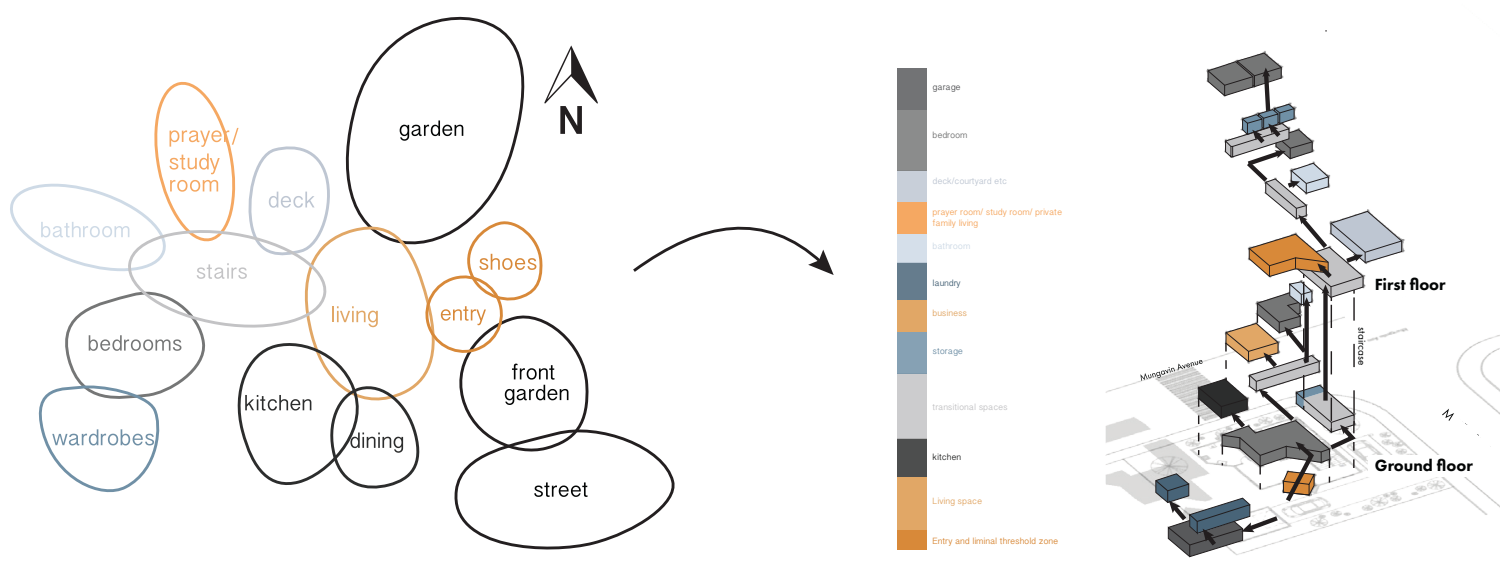

Figure 4.07 Spatial programming diagram drawn from primary source information. These two diagrams show the similarities and differences between these two sets of information. 


\section{Spatial programming}

Information from the interviews revealed that spatial programming was the most important aspect of the design. Interviewees were not as interested in aesthetic qualities such as the colour of the walls or curtains. The programmatic requirements revealed as important are listed below:

- Entrance: the front entrance to the house should face east, or approximately east. This is because the fresh air brought in by the morning sun is considered to bring good luck.

\section{- Exterior/Interior threshold}

house: This space should have an obvious shoe-taking-off area. As Myanmar Ethnic people commonly sit on the ground and not on furniture, they like to keep the floor as clean as possible.

- Living space: Hospitality is highly important, and Myanmar culture is communal. This means that the living room is considered a semi-public space and should be able to accommodate plenty of guests.

- Downstairs toilet: An

additional downstairs toilet was requested in two storied houses for an older family member who may be sleeping downstairs.

This also works well with restaurant compliance, in which restaurants are required to have toilets (safe food, 2016).
- Children: An outdoor safe space for children to play such as an upstairs deck. This is because children like to play freely and there was worry about the speed of cars on New Zealand streets. The space would either be easily viewable or designed so small children couldn't climb out.

- Prayer room: which could also act as a quiet place for children to study.

- Bedrooms: These are considered totally private. As the living room can operate as a semi-public space and hospitality is important, they should be obviously separate from less private spaces.

\section{- Wardrobes: Myanmar Ethnics} like to have bedrooms which are totally private and only for sleeping in. This was considered important to create a restful space. For this reason, the wardrobes should be outside bedrooms.

- Kitchen: The kitchen should be in a separate room to keep cooking smells away from other parts of the house. This space requires good ventilation and there was some worry about these smells bothering neighbours. There is typically a dining space within the kitchen which can be defined by a circular table. Mealtimes are social affairs, and the circular table was considered social because everyone is looking at each other. 


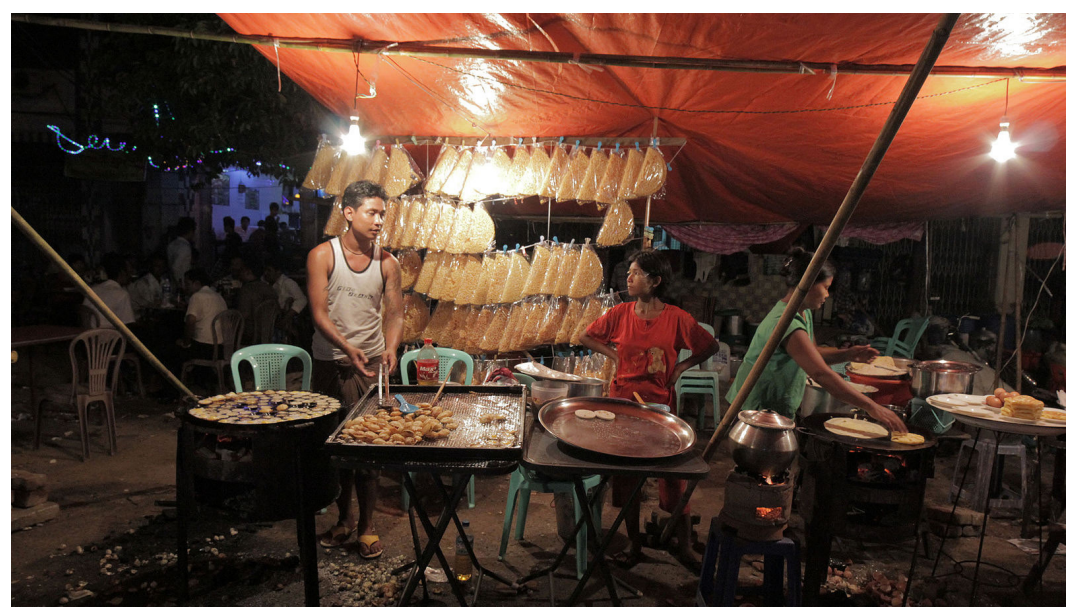

Figure 4.08

A traditional snack shop in Myanmar, photo by Lionslayer

Typical Myanmar Ethnics Groups recipes

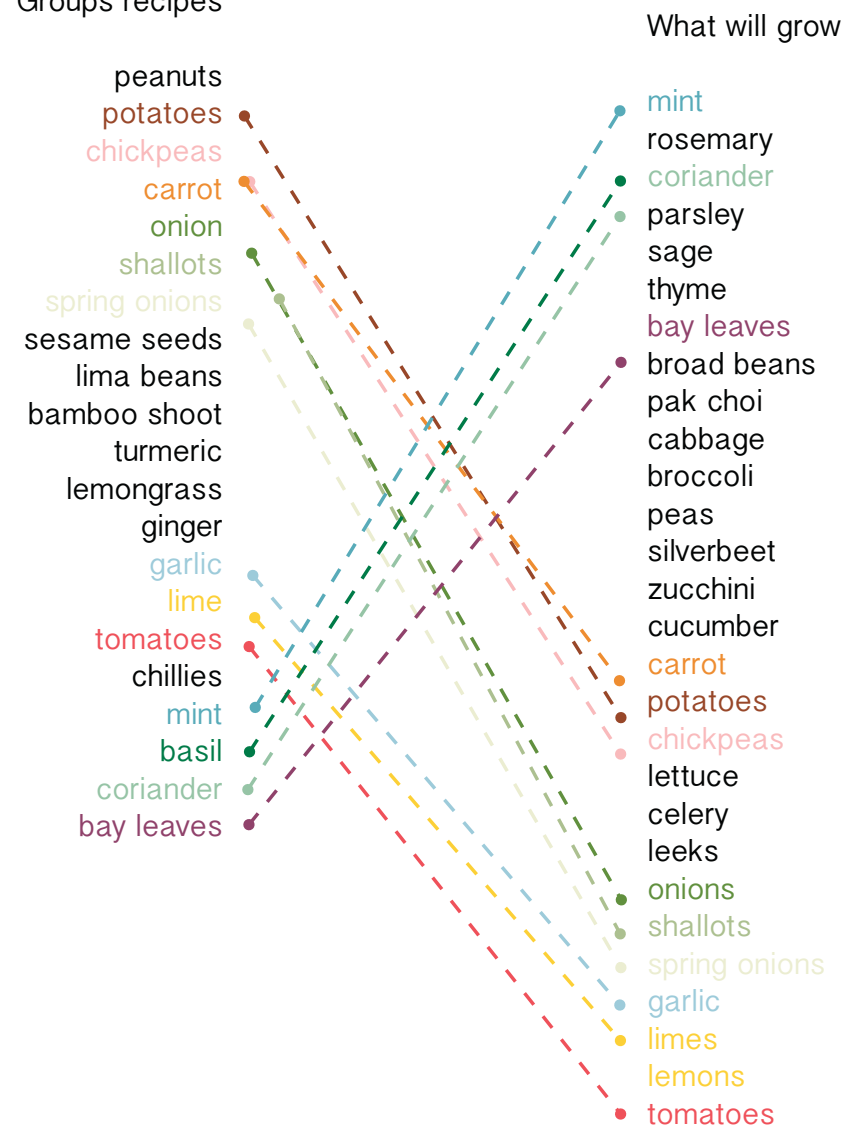

Figure 4.09 A diagram which shows which vegetables used in typical Myanmar cuisine will grow in New Zealand 


\section{Self-Employment opportunities}

"Several of the women spoke of setting up businesses, such as opening a small shop, and one woman was keen to expand her sewing business beyond the local Burmese community." (Kamri-McGurk, 2012:137)

"She explained also that there had been some discussion of opening a Burmese community shop: We can sell Burmese food and everyone would be interested. I think we can do the business."

(Kamri-McGurk, 2012:133)

These statements from KamriMcGurk's thesis show that members of the Myanmar Ethnics community in Wellington would be interested in running a business.

During the interview process for this thesis, the desired business discussed was preparing food for the community. An idea was to start out as a catering company with the potential to expand into a restaurant. The interviewees did not initially want signs on the business, but to gain customers through word of mouth.

As a business which will be growing out of the kitchen, the kitchen should be carefully orientated for future expansion. In New Zealand, a Food Safety Certificate is required to sell food commercially. As per Code Compliance, the basics of this are:

- approximately $3.4 \mathrm{~m}$ between floor heights for ventilation, - commercial surfaces (floor and benches), such as stainless steel benches and, - a toilet for customer use. - while the space can function as residential and commercial, the uses must be kept separate either by space or time. 


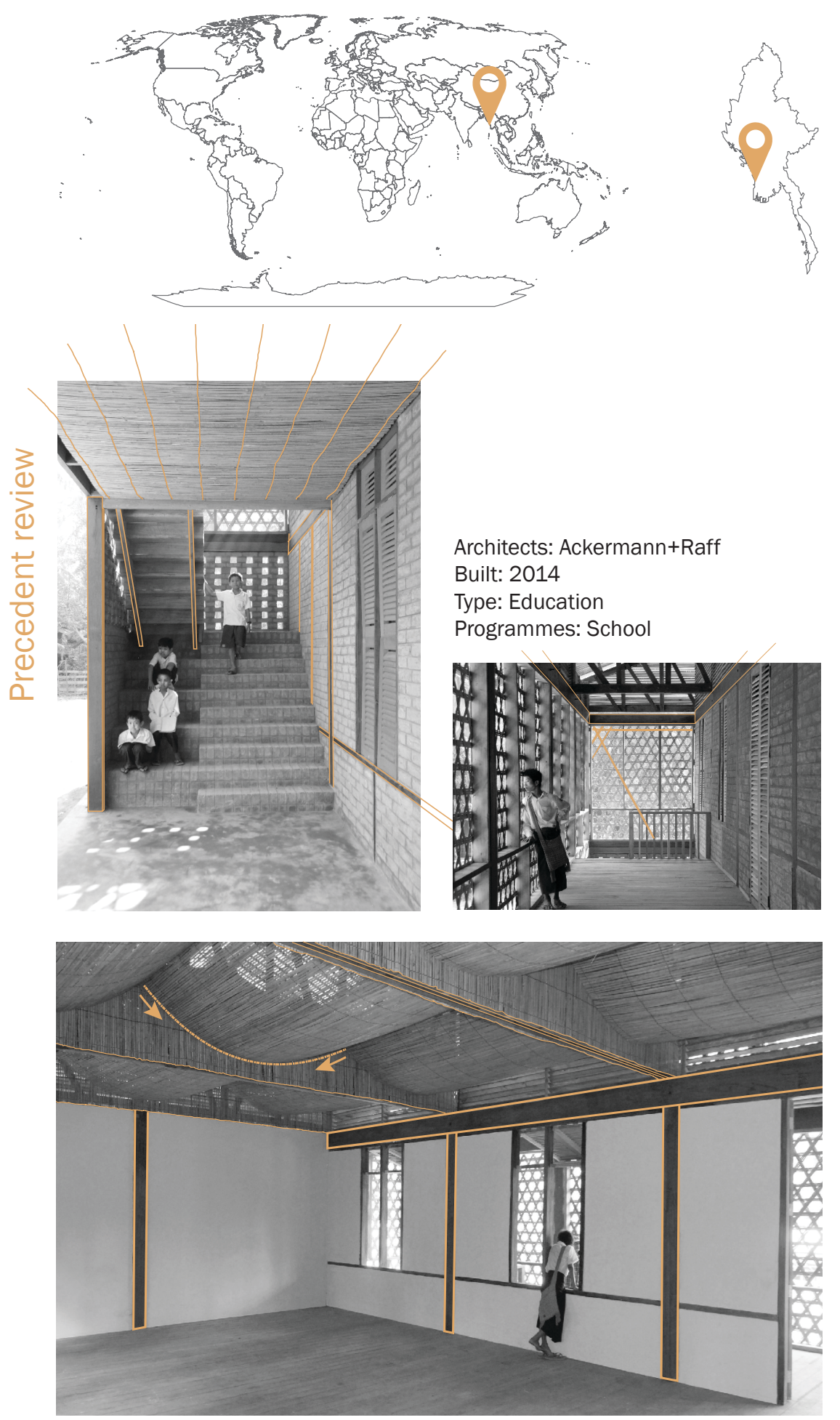

Figure 4.10 High school Thazin, photos by Julia Raff 


\section{High School Thazin}

This precedent (figure 4.10) was built in 2014 in a small holiday town in the Irrawaddy region of Myanmar and is designed using typical construction techniques. These techniques are:

- timber framing with brick infill, - woven ventilation screens, - a hanging bamboo ceiling and, - timber shutters.

These features are interesting because:

- through physical weight, the bricks provide a sense of permanence
- while the timber lacks the physical weight of the bricks, it provides a supple natural symmetry (fluidity) - the woven ventilation screens provide decorative interest, - a sheltered environment is created with the woven ventilation screens and the hanging bamboo ceiling which filters soft natural light into the spaces and, - the timber shutters are an interactive element with which the children can play and connect. 

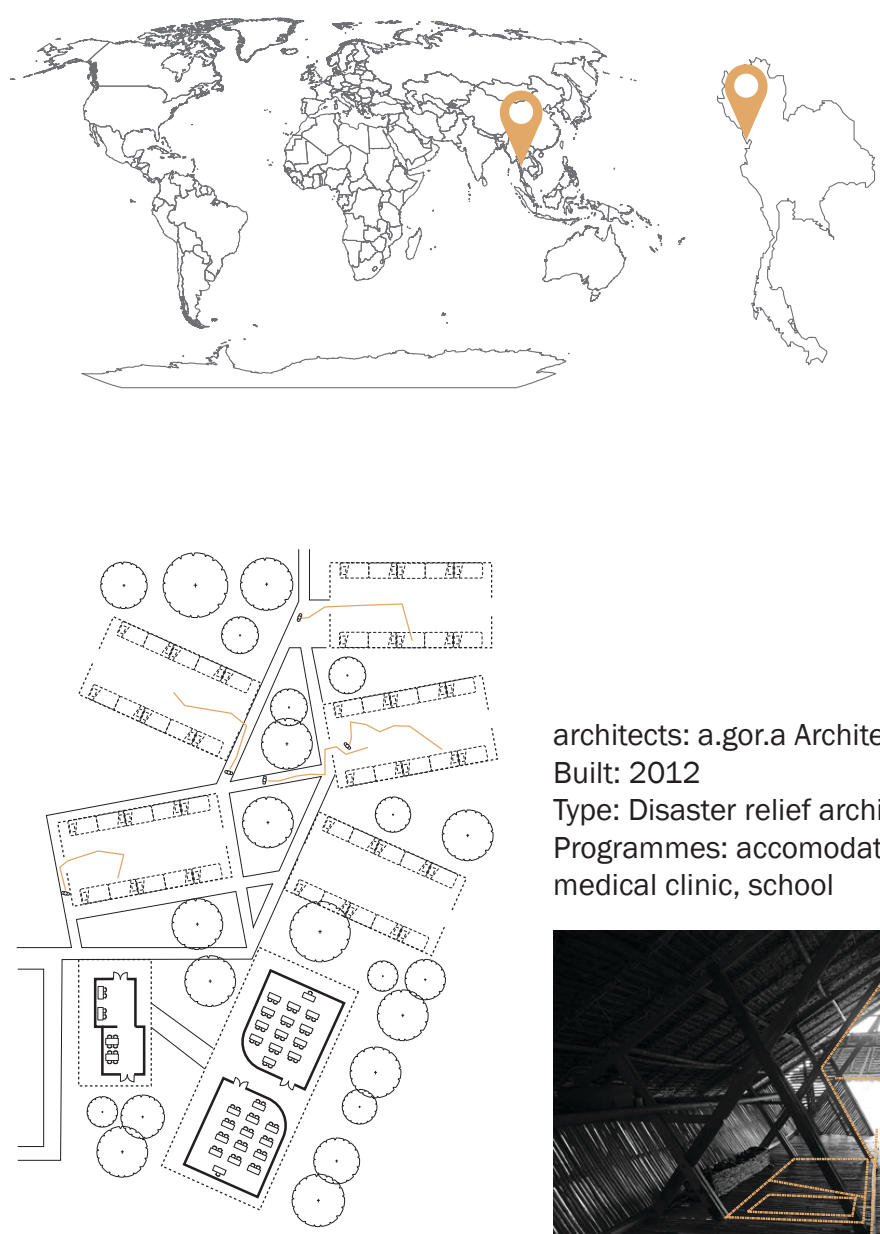

architects: a.gor.a Architects

Built: 2012

Type: Disaster relief architecture

Programmes: accomodation,

medical clinic, school
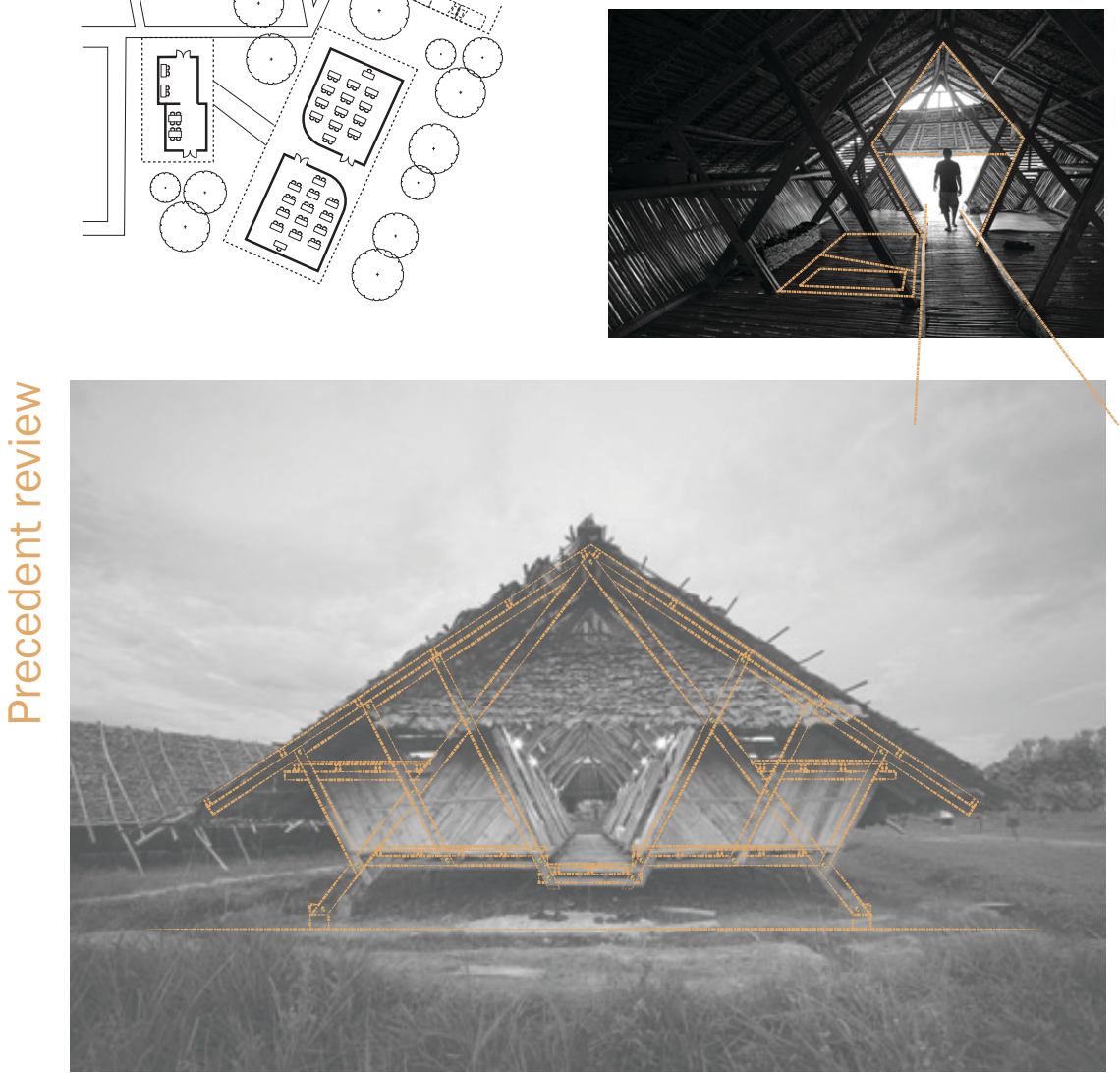

Figure 4.11 Mae Tao dormitories, photos by a.gor.a architects. 


\section{Mae Tao dormitories}

This simple structure (figure 4.11) is a compact dormitory found in a refugee camp near the Thai-Myanmar border. It exists to provide basic shelter and is designed to be easily constructed by the camp's inhabitants. This precedent is valuable as a basic summary of materials, construction and environmental conditions in Myanmar, which manifest in: - timber framing, connected with pin-joints

- raised floor

- air gap between walls and roof - bamboo used as a woven wall, and as a roof thatch. 

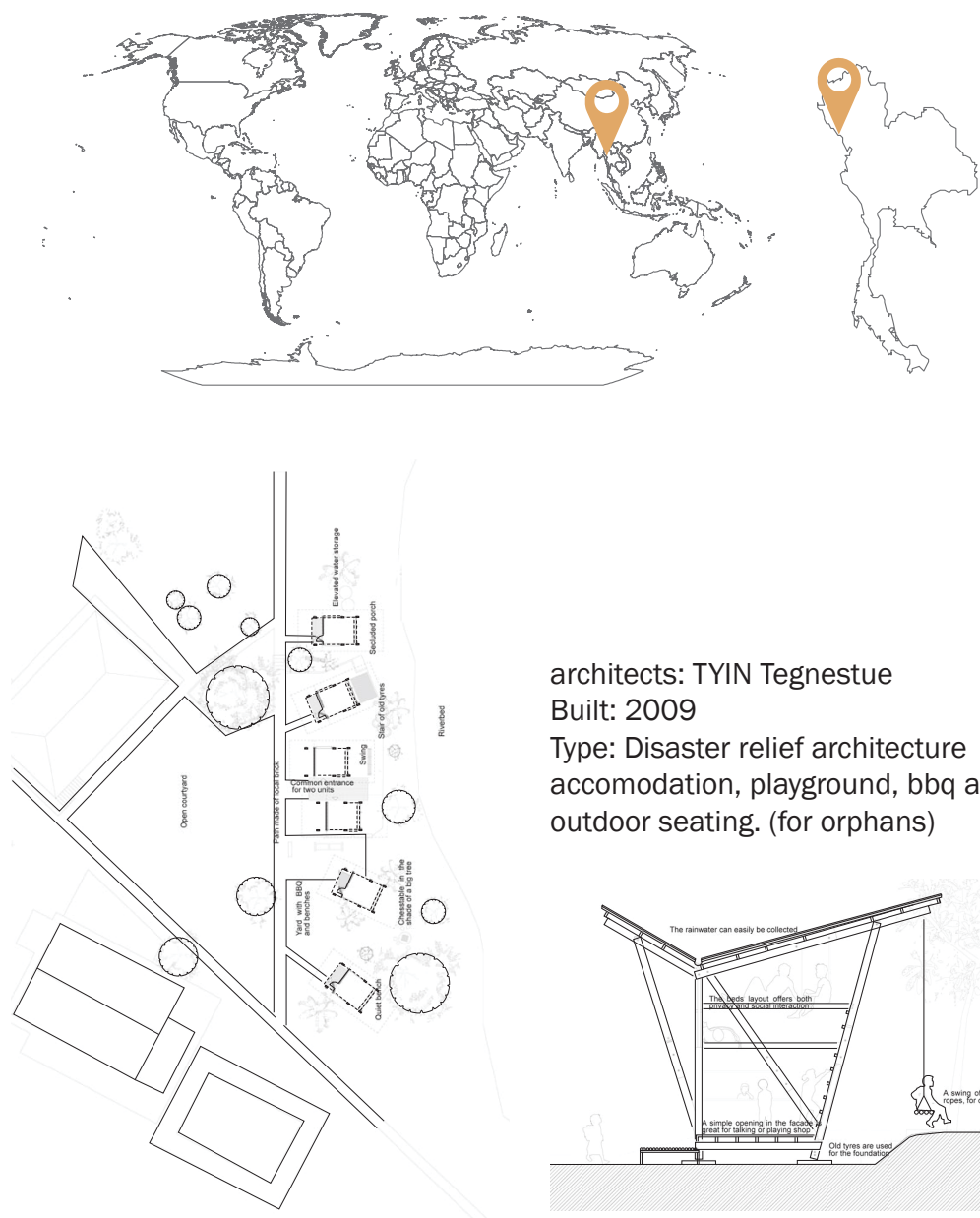

architects: TYIN Tegnestue

Built: 2009

Type: Disaster relief architecture accomodation, playground, bbq and outdoor seating. (for orphans)
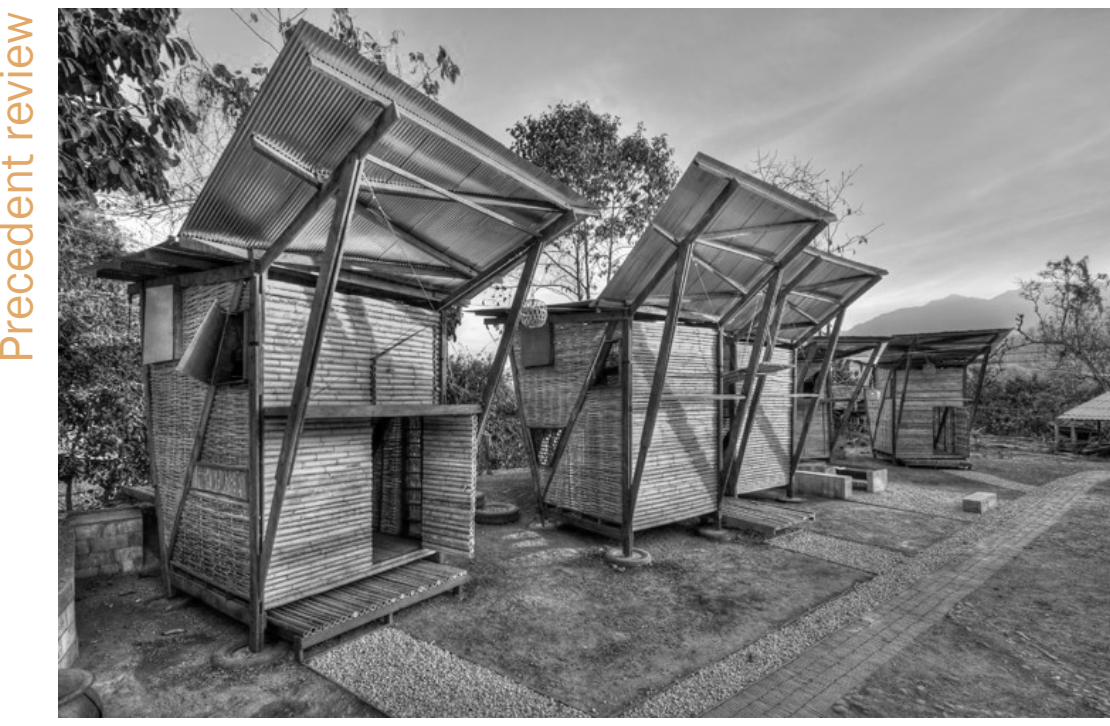

Figure 4.12

Soe ker tie house, photo by Pasi Aalto 


\section{Soe ker tie house}

Found in a refugee camp north of Mae Tao dormitories, these small units (figure 4.12) are temporary housing for an orphanage. Along with similar materials and construction techniques used in the Mae Tao dormitories, what is interesting about this precedent is: - bunk beds provide privacy through vertical separation, which takes up little space - playful elements, such as a swing set attached to the arching roof. 


\section{Reflection}

The Myanmar Ethnics community in New Zealand is diverse, with the potential to further contribute to New Zealand. Dwellings in Myanmar are different to dwellings in New Zealand, with some important differences being:

- east facing entrance with an area for taking off shoes,

- a large welcoming living room, - a separate kitchen with a circular dining table and, - wardrobes outside private bedrooms.
With the potential business growing from the kitchen, the kitchen will need to be carefully orientated and able to gain a Food Safety Certificate. The precedent reviews supplemented the interview process by providing information on material, construction and decorative elements. In particular, the Mae Tao dormitories and Soe ker tie house show which elements from the vernacular study could be environmental design which will be investigated during the iterative design process. 


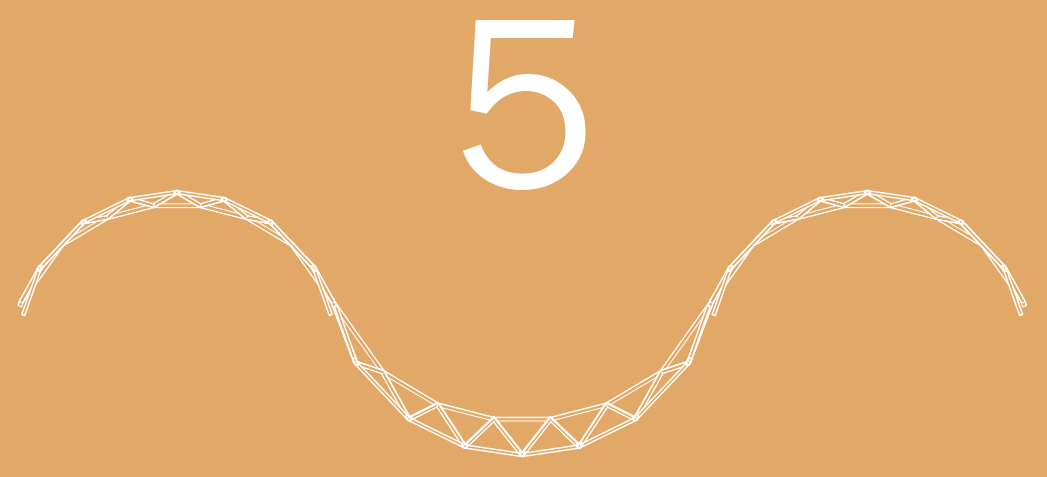




\section{Site analysis}

This section examines the

potential for connection which chosen site for the project. This mainly investigates commercial activity in the area, and the could encourage intercultural contact. 


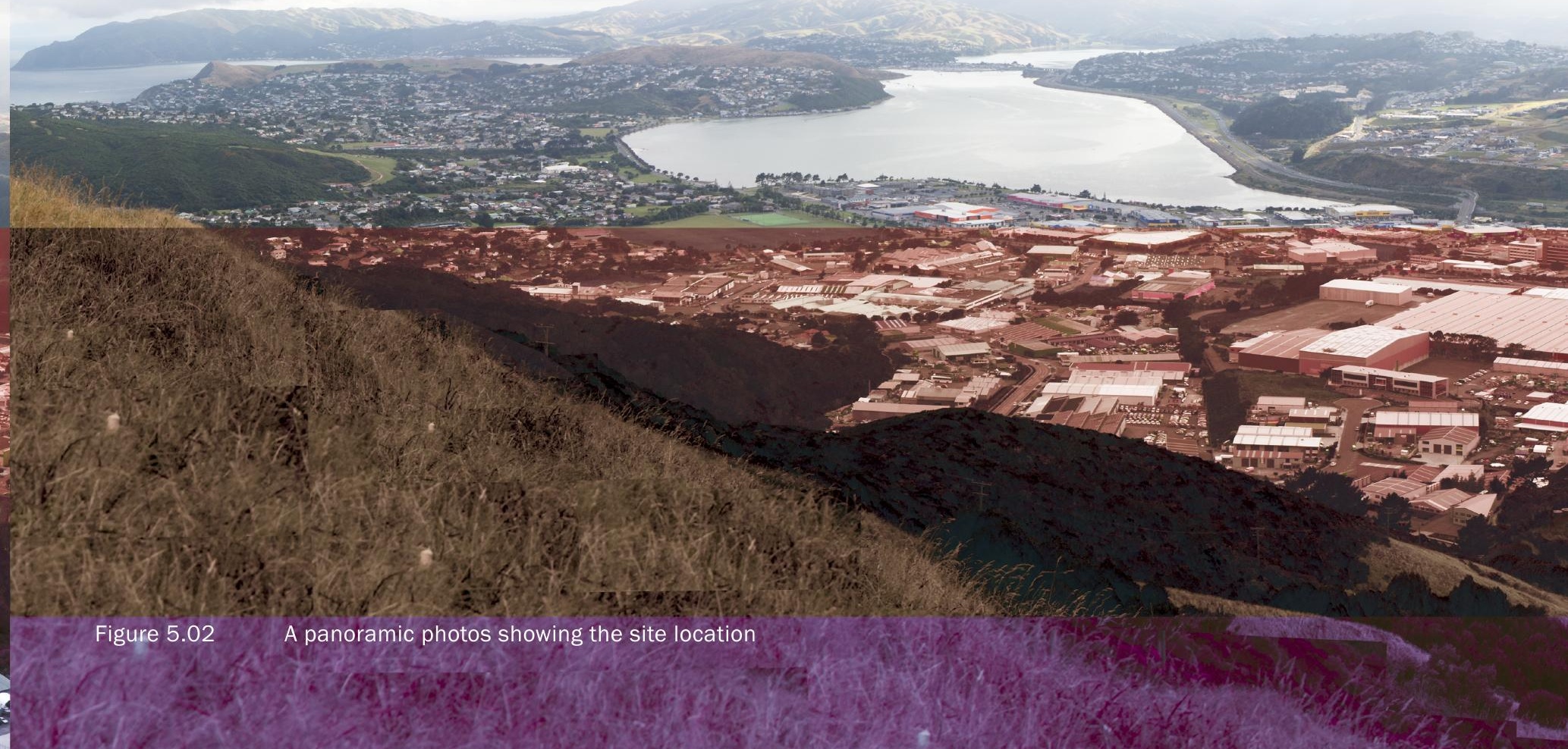




\section{SITE}

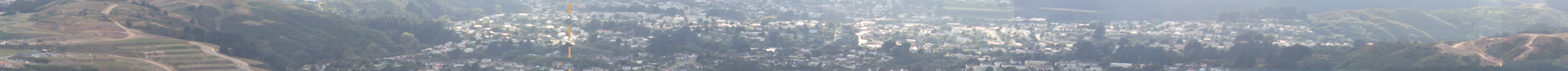

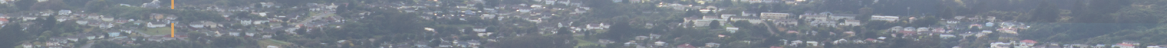

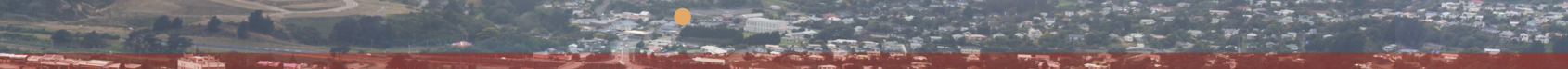

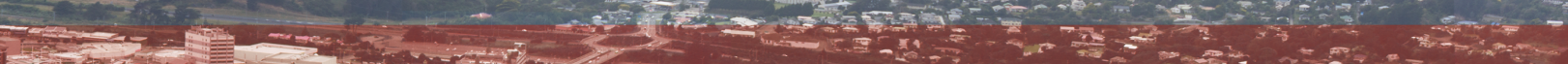

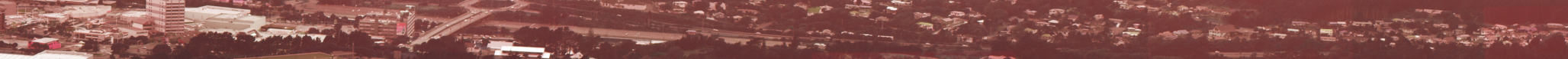
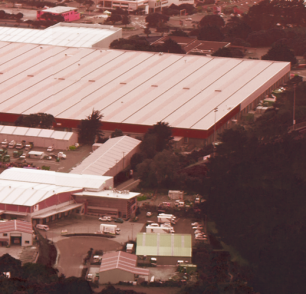

(1)
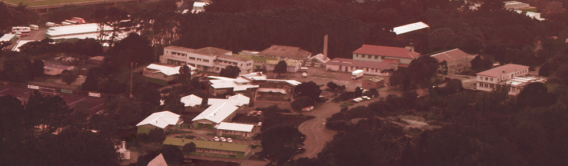

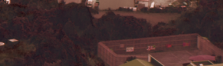

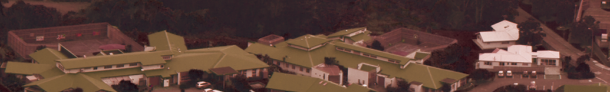

2

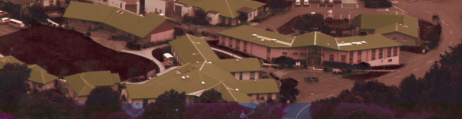

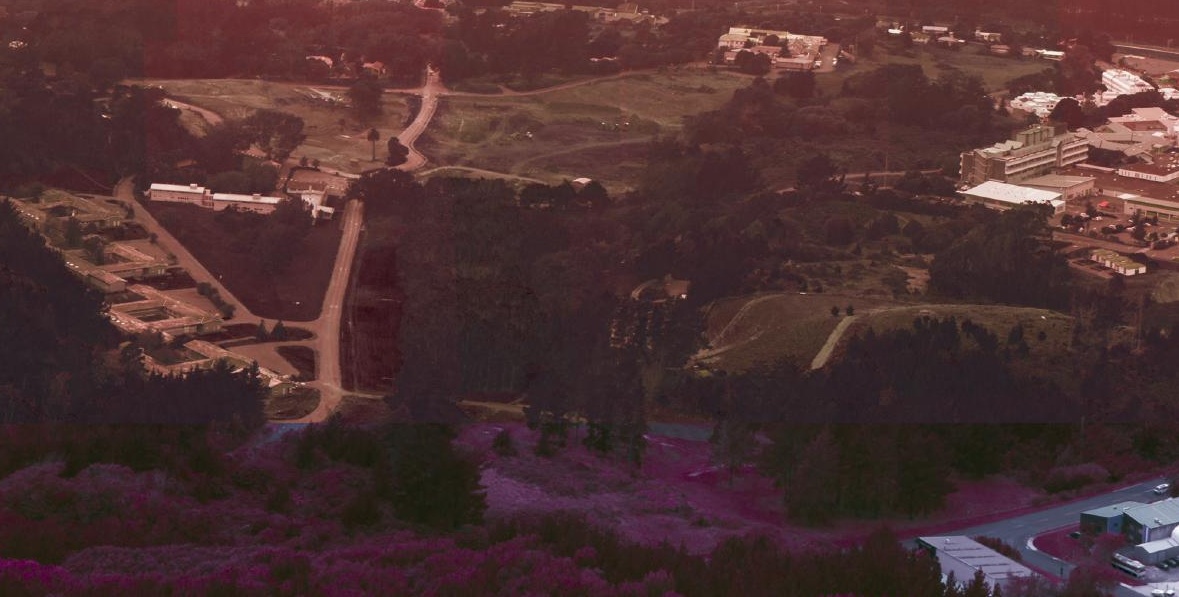



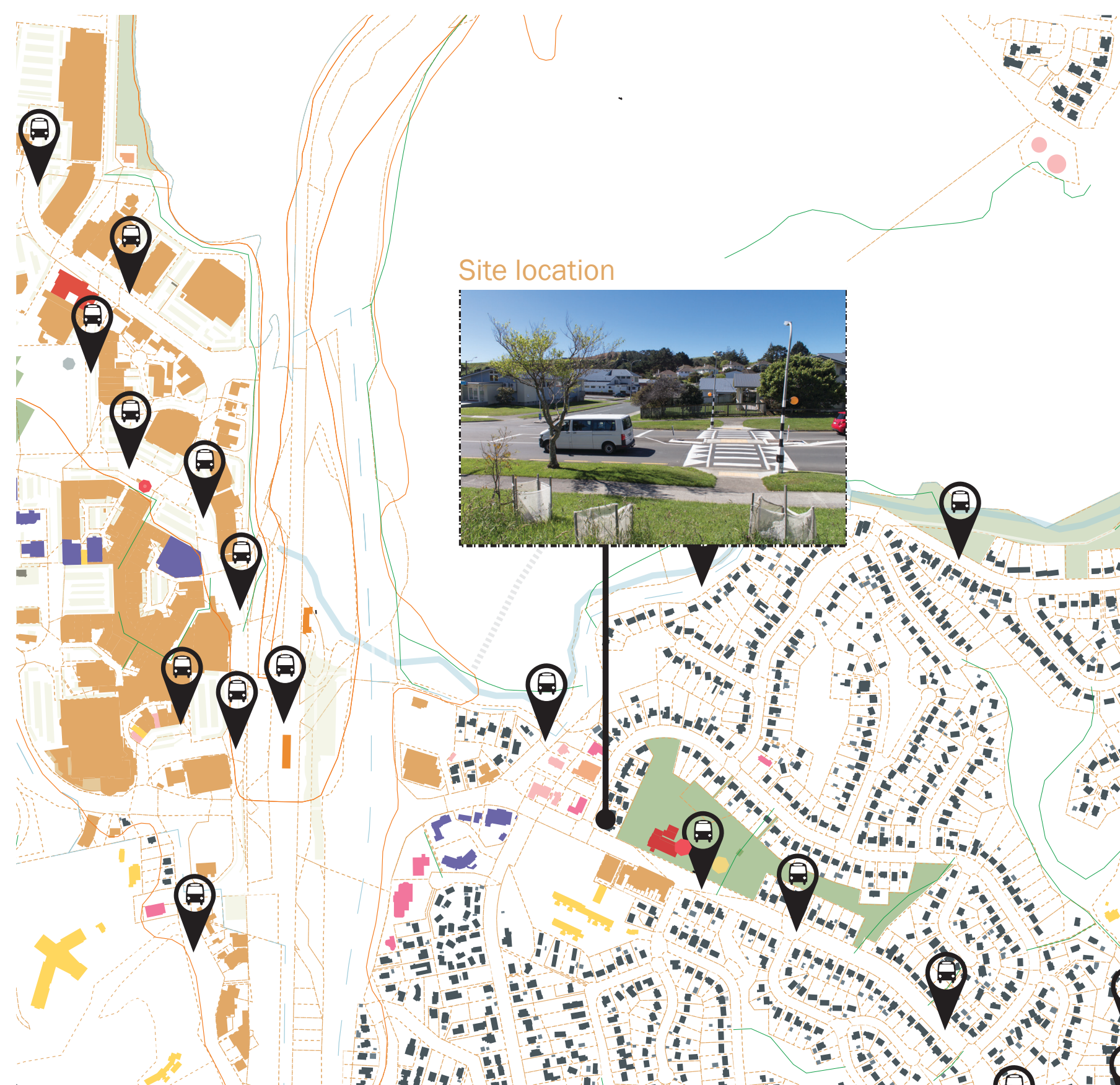

\section{Site location}

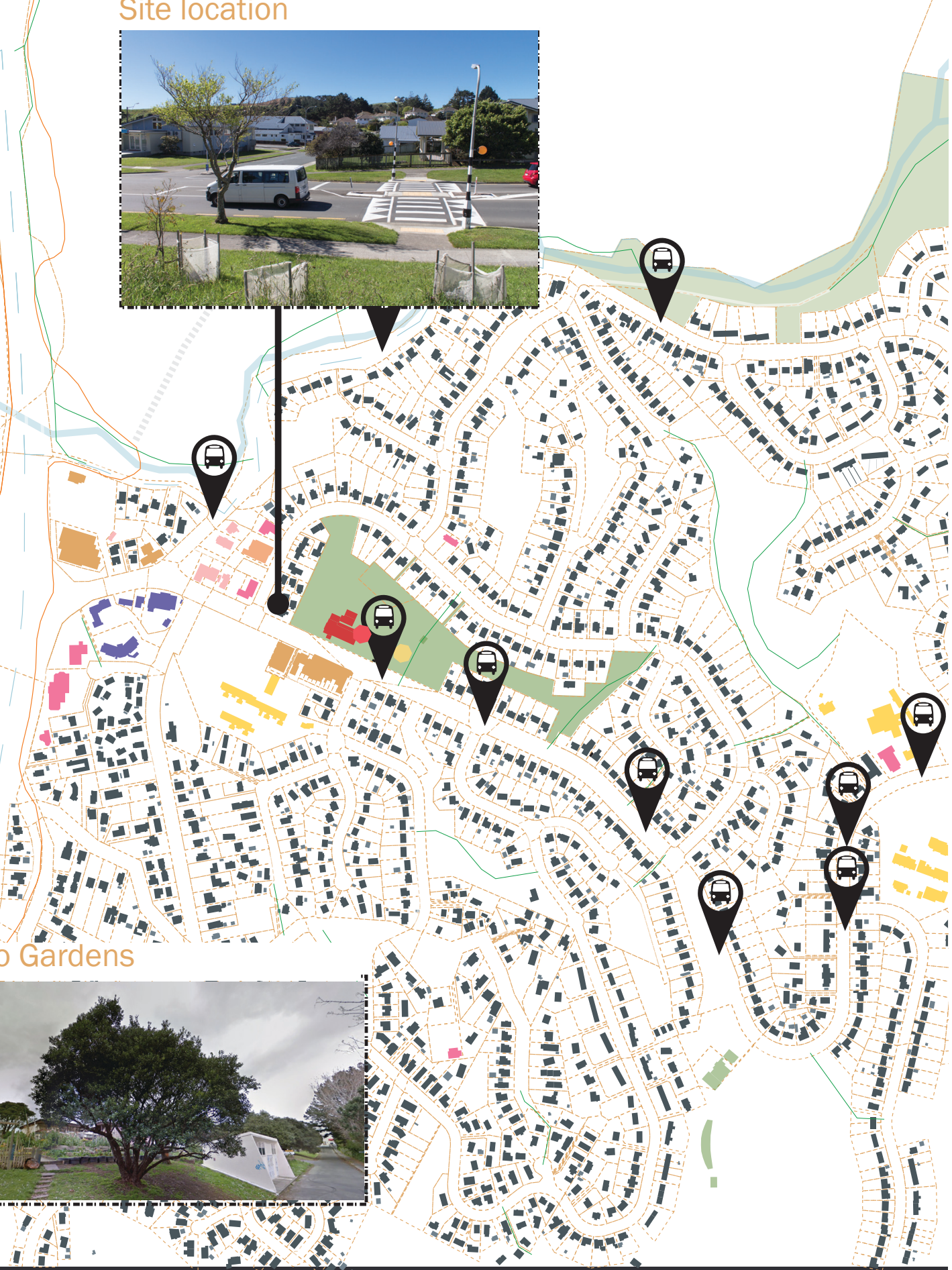

public space

$\begin{array}{ll}=\text { playground } & =\text { dog walk area } \\ =\text { skate park } & =\text { = } \\ \text { = sports ground } & \square=\text { suburb boundaries }\end{array}$



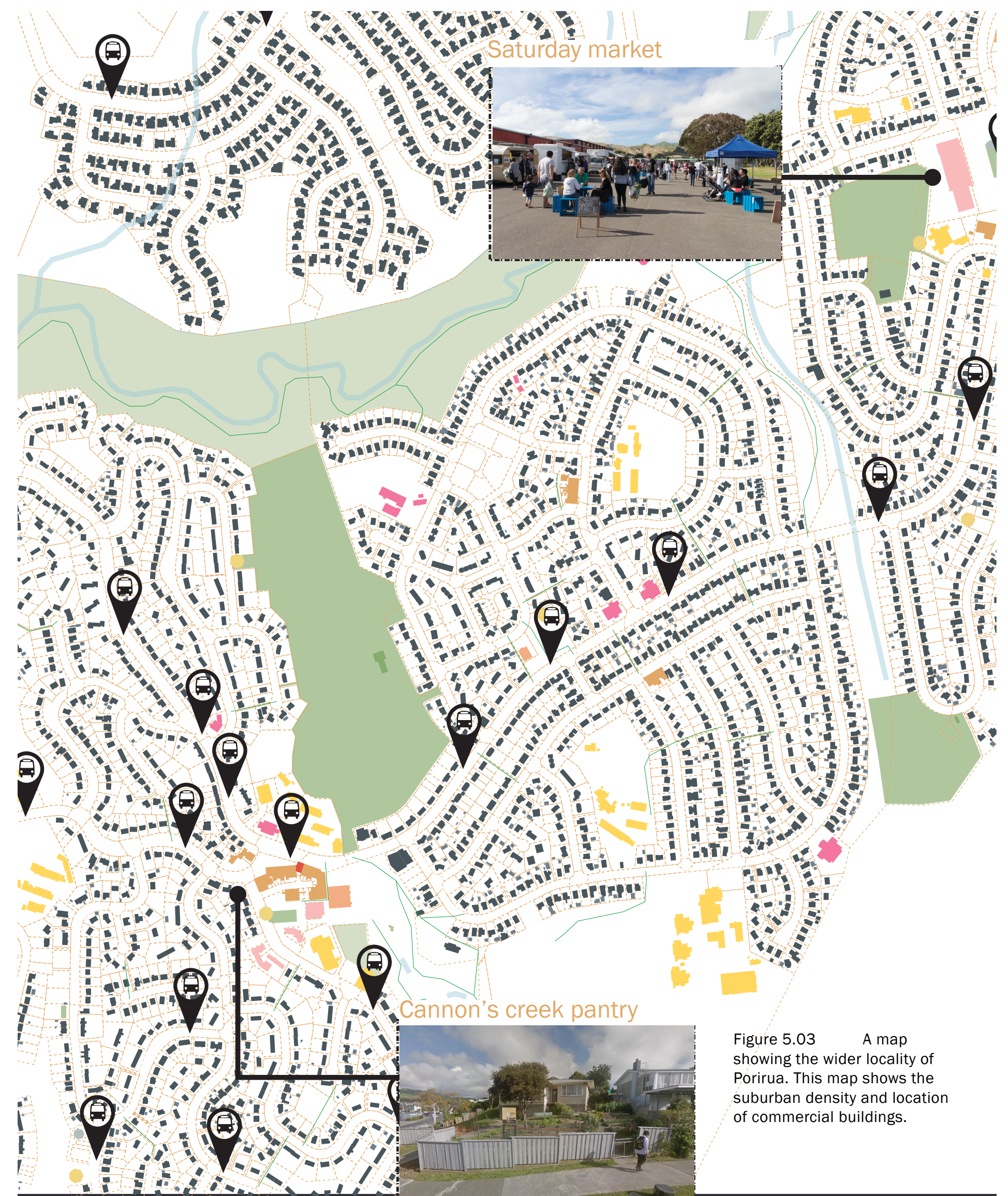

Figure $5.03 \quad$ A map showing the wider locality of Porirua. This map shows the suburban density and location of commercial buildings.

\section{building}

=shed/garage

=house

=business
$=$ cultural centre

=church

=school =medical

=industry/agriculture =water tank

= gvtcentre 

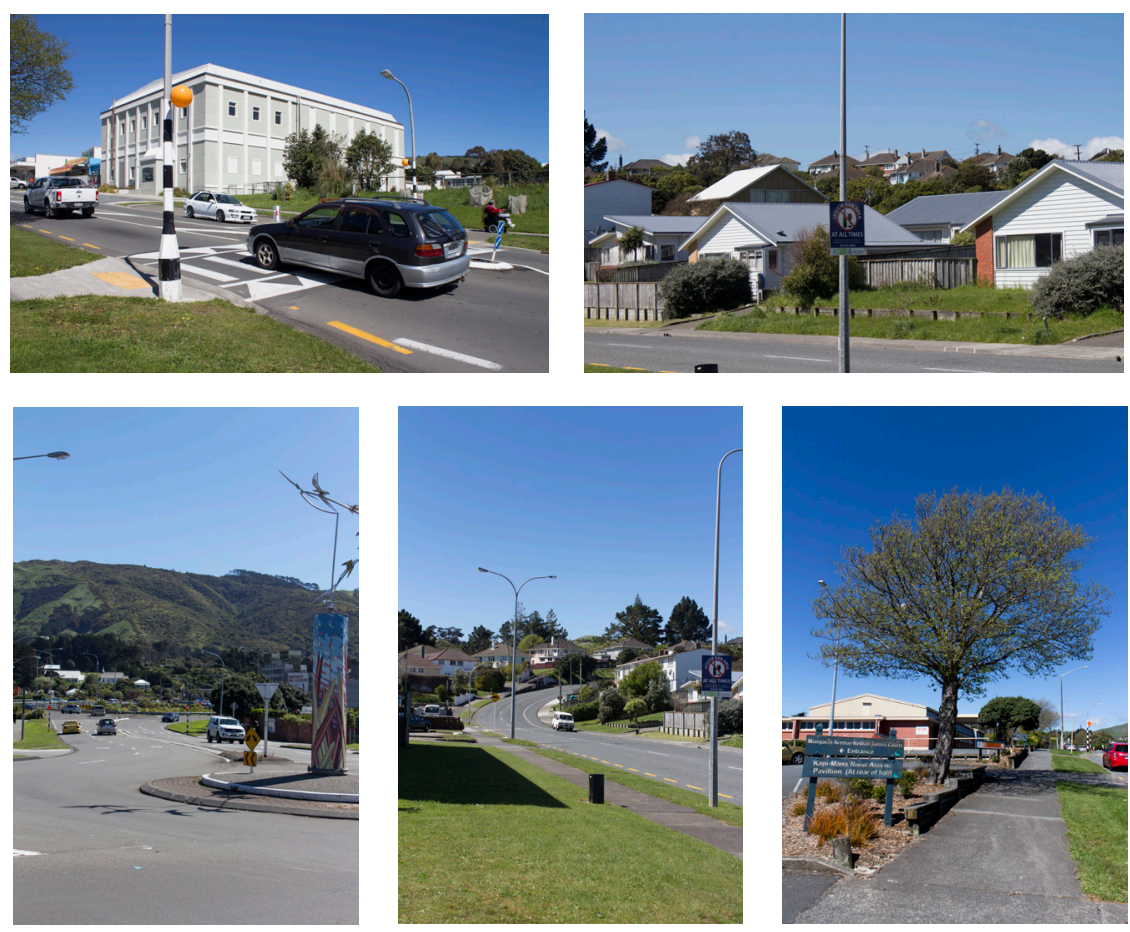

Figure 5.05

Site map and impressions

\section{Direct locality}

The site for this thesis was chosen by identifying an area with a large percentage of Myanmar community members and by identifying a site with a large amount of visibility to increase the potential to start a business.

The site chosen in Porirua is on a corner, easily accessible by car or foot, near other businesses (figure 5.05). It currently doesn't have a business on it and is next to a community hall and sports field and across the road from a school, church and medical centers. The nearby businesses are not the same as the business desired by the interviewees (figure $5.07 \& 5.08$ ), which is an important factor for a successful business and also to ensure good relationships with commercial neighbours.

The chosen site is not in Porirua's CBD but it is in an area with plenty of commercial and community amenities which means it is already well used and could have potential to grow. 


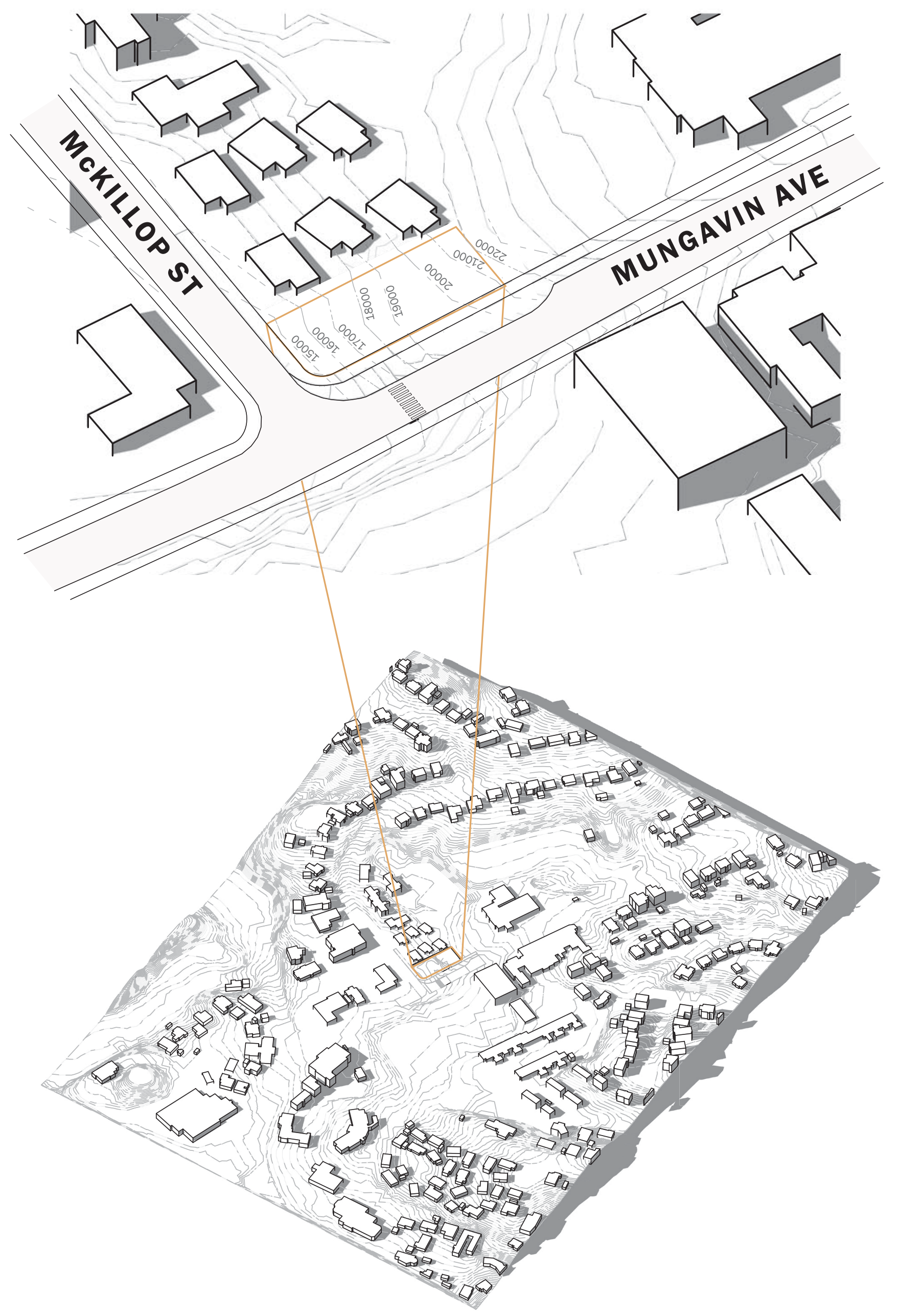




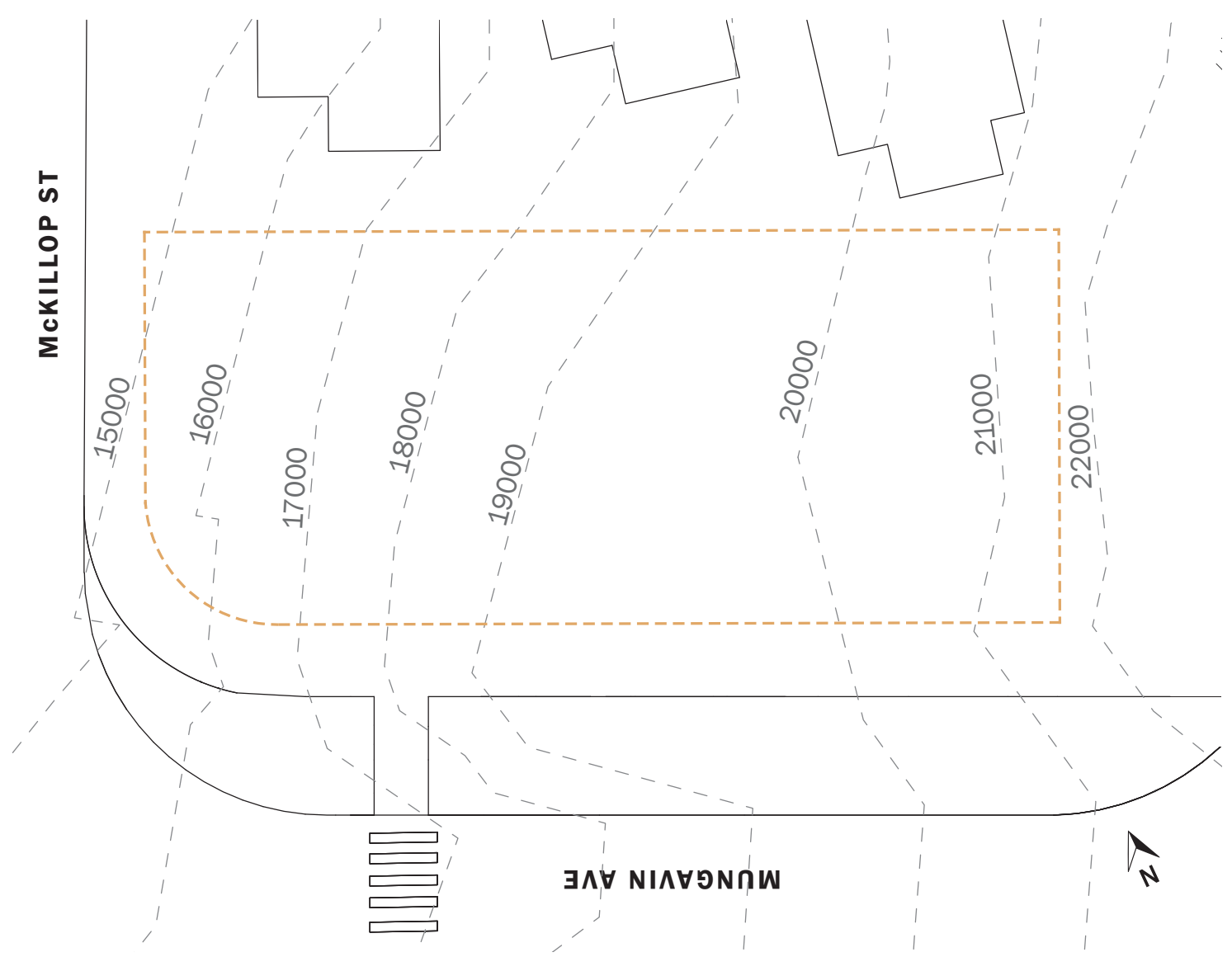

Figure 5.06 maps for site analysis showing existing contours. 


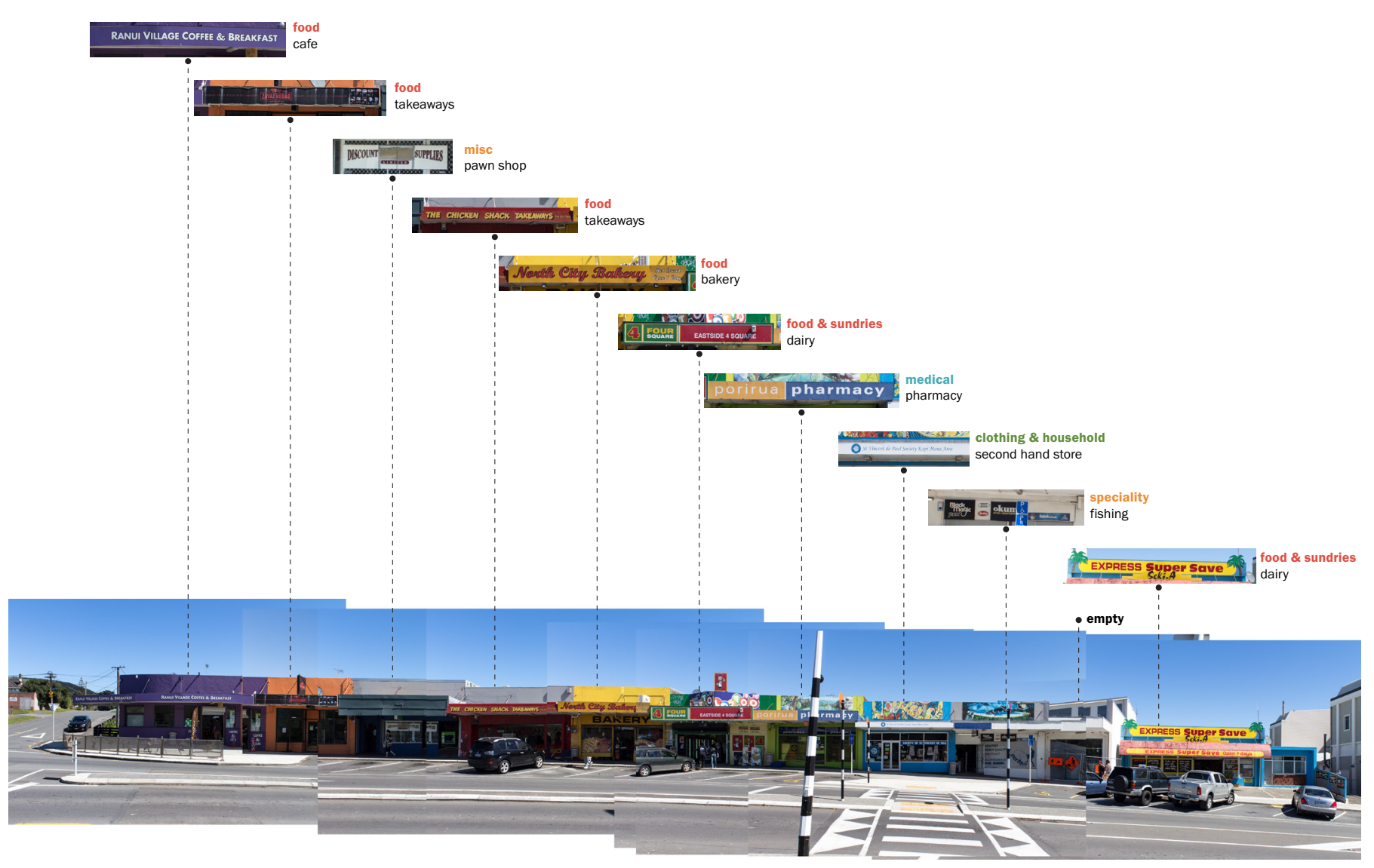

Figure 5.07 The block of shops across the road from the site 

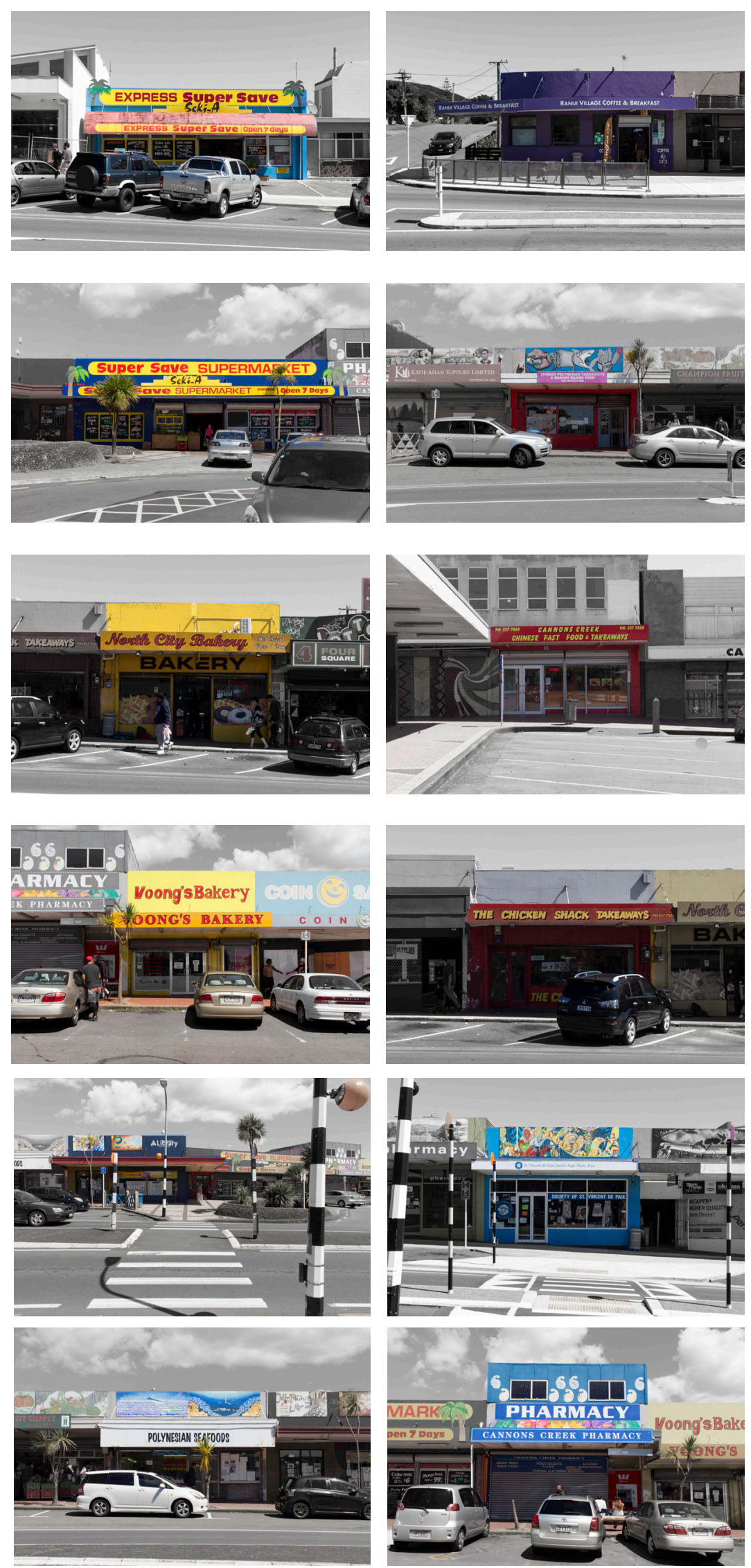

Figure 5.08

photos of shops in site locality 


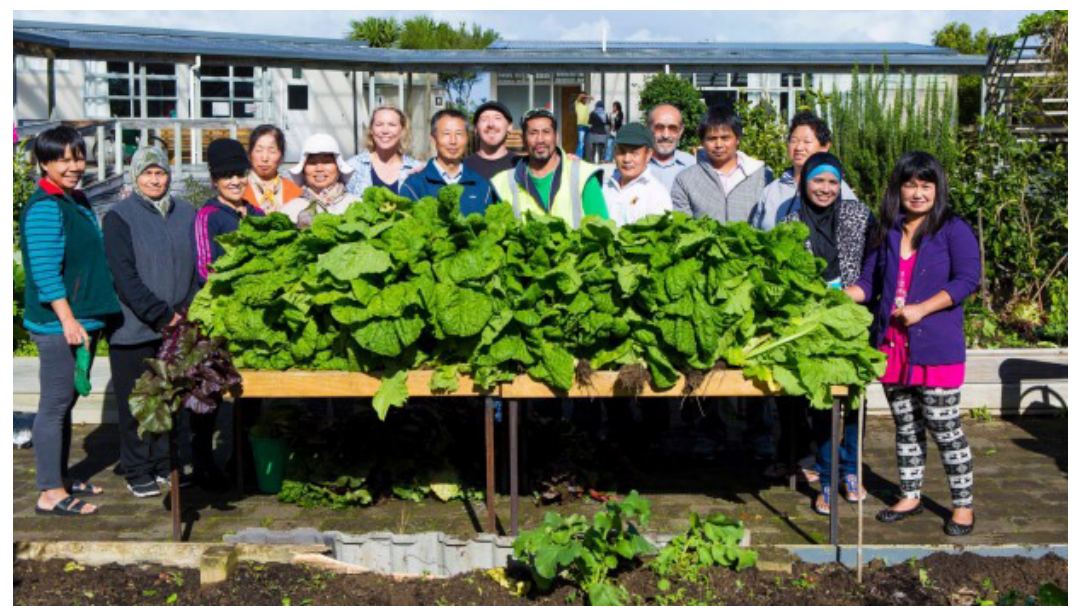

Figure 5.09 A community garden, photo by Jay Creaghan 


\section{Gardens}

To integrate with the wider community, complementary elements of the site are considered and include: - next to a town hall, which has a small library and an active sports field.

- two community gardens in the area: Te Rito gardens to the east and Cannon's Creek community pantry to the west.

- Saturday market held to the north-west

- pedestrian crossing which connects from Porirua East School and a small community orchard

"All the women have gardens and plant flowers and vegetables. Seven of the ten women made frequent references to gardening and how much they enjoy it. This could be seen as part of a process of regaining control over their lives and enjoying the stability of watching the fruits of their efforts grow." (KamriMcGurk, 2012:109)

The above statement shows the value the Myanmar community members can gain from gardening. Gardening in New Zealand may be different to what they are used to, for example people from this community are not familiar with compost making and use (Kamri-McGurk, 2012:111). This is why the community gardens have been included as part of this project, as they can offer gardening courses and support. 


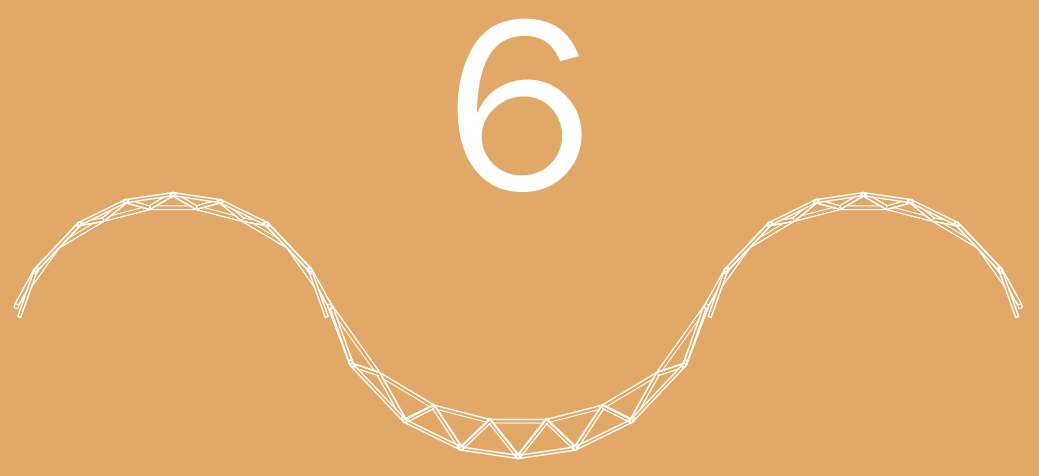




\section{Preliminary design}

This section begins with a reflection of the initial review. Next, it documents the initial design experiments. At this stage in the design process the objectives were to:

- develop an architectural strategy that would allow the business to grow without compromising the spatial integrity of either business or home and,
- develop a coherent architectural language that differentiated business from dwelling or, a cohesive and coherent architectural relationship between the two.

These objectives were explored through sketches, 3-D visualization and hand modelling. 

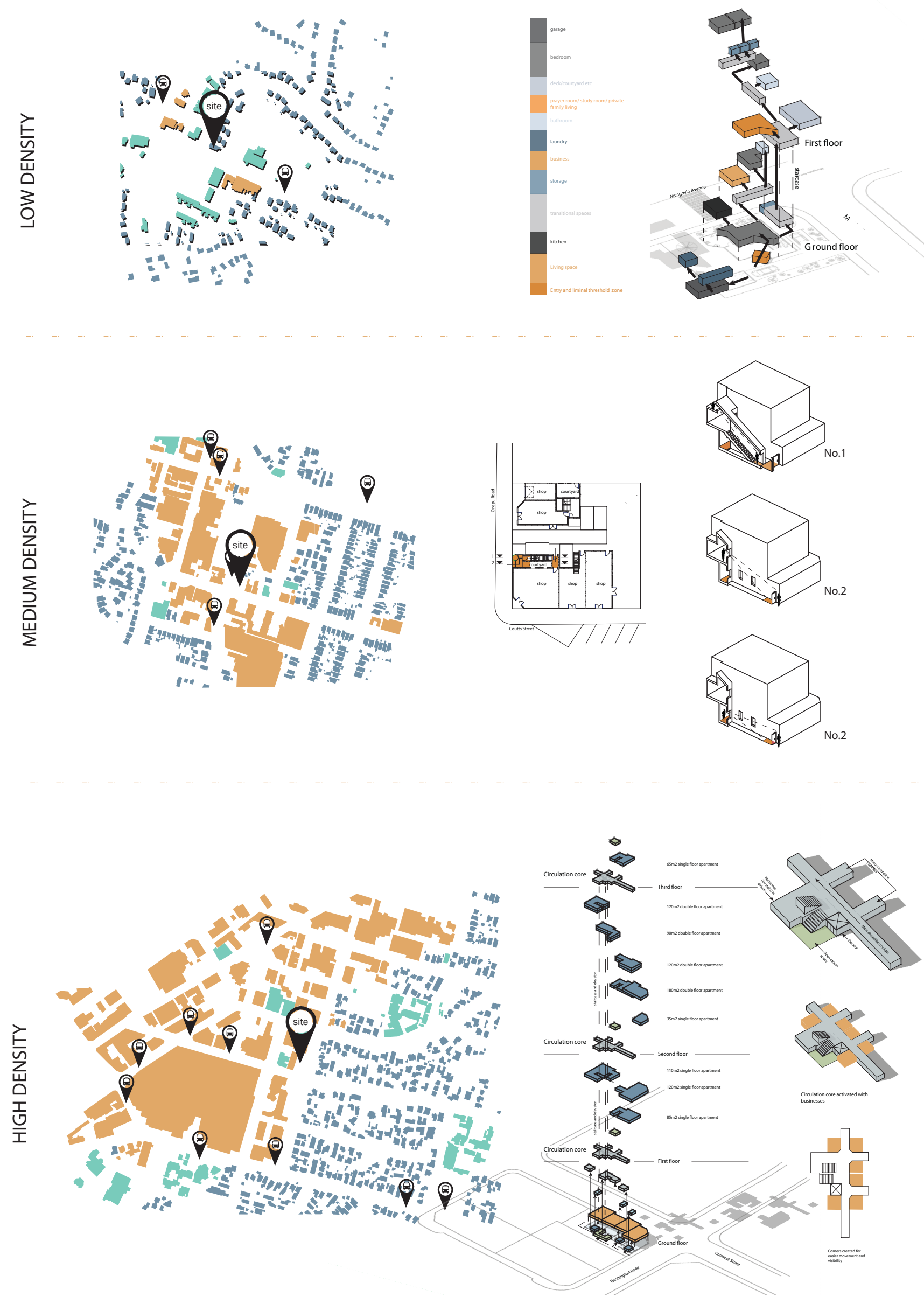


\section{Initial review}

For this initial review, the project was presented as three buildings at three different densities for the people of three different countries (figure 5.01). This was done to explore and test the potentials and opportunities that could be present within the shophouse type and to make the project large enough. The two major criticisms received for this proposal was that the project was too large, and that designing a building for a

particular culture was a bad idea from an outsiders' perspective because it would never be able to truly represent that culture.

Applying these criticisms to the project, it was decided the project would produce an outcome for the people of a single country, with the most important information being gathered from primary sources. Initial advice was to discuss the project in terms of a single family. 

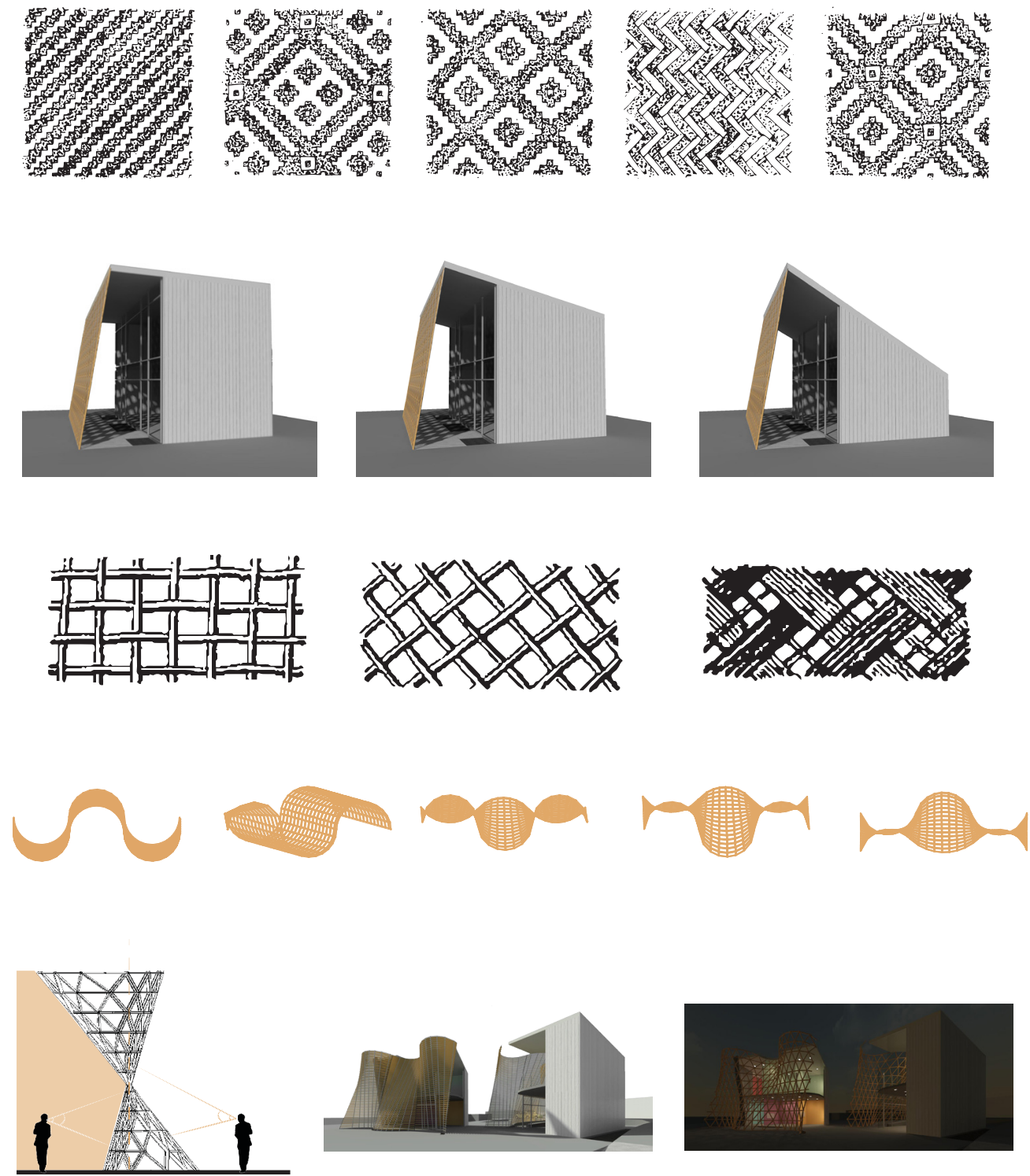

Figure 6.01

Weaving patterns, as seen

in Myanmar vernacular architecture, are applied to a woven ventilation screen. To take this experiment further, the screen becomes the veranda which attempts to express its liminal zone as a 3-dimensional sculptural form. The curved form is regarded as a mediating interface, meaning that it is a 3-dimensional zone with the community members on one side and the public on the other. 


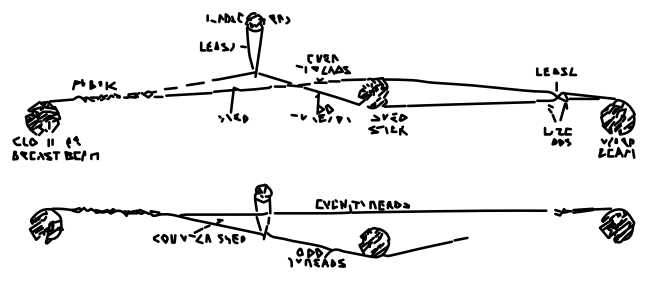

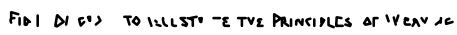
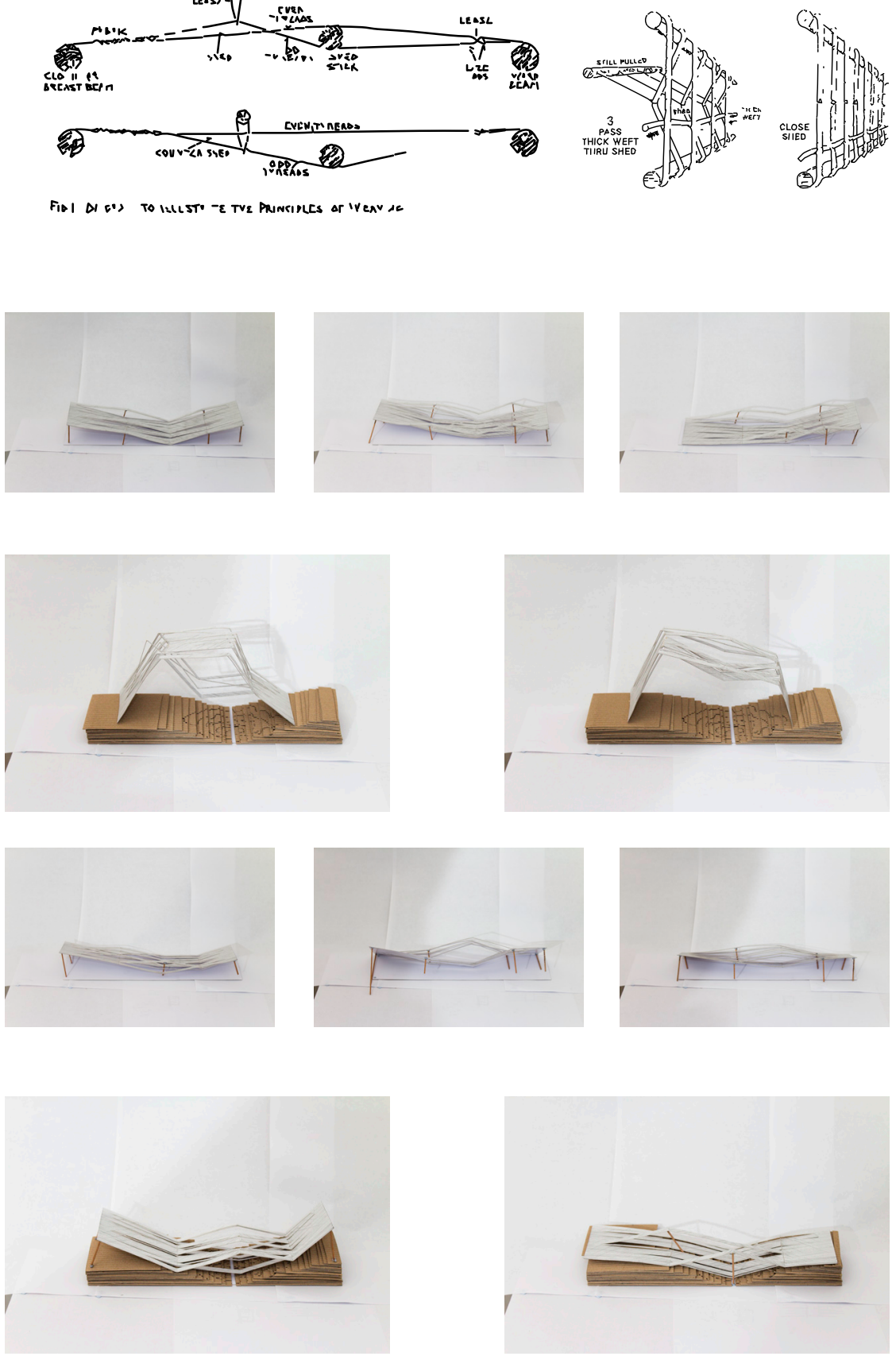

Figure 6.02

To further investigate weaving as a design element, weaving is regarded as joining together two separate things such as a dwelling and a business. This

process was inspired by the movement of a loom, to continue the weaving theme and because that Myanmar is well-known for weaving patterned clothing. 

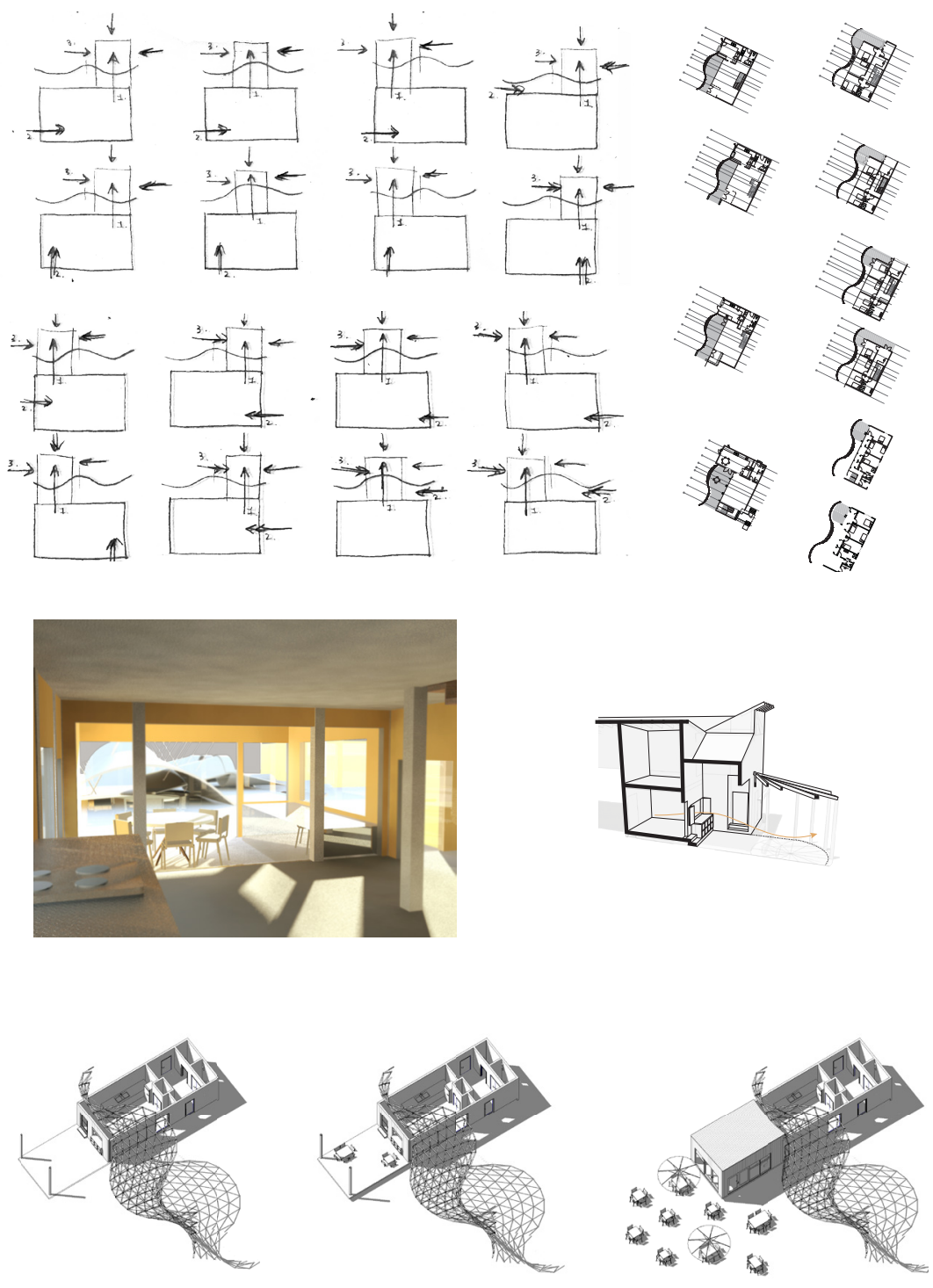

Figure 6.03

Methods of extending a

want the business to be visible restaurant out from the kitchen are explored because the from outside the house and community members did not because the business was to be run from the kitchen. 


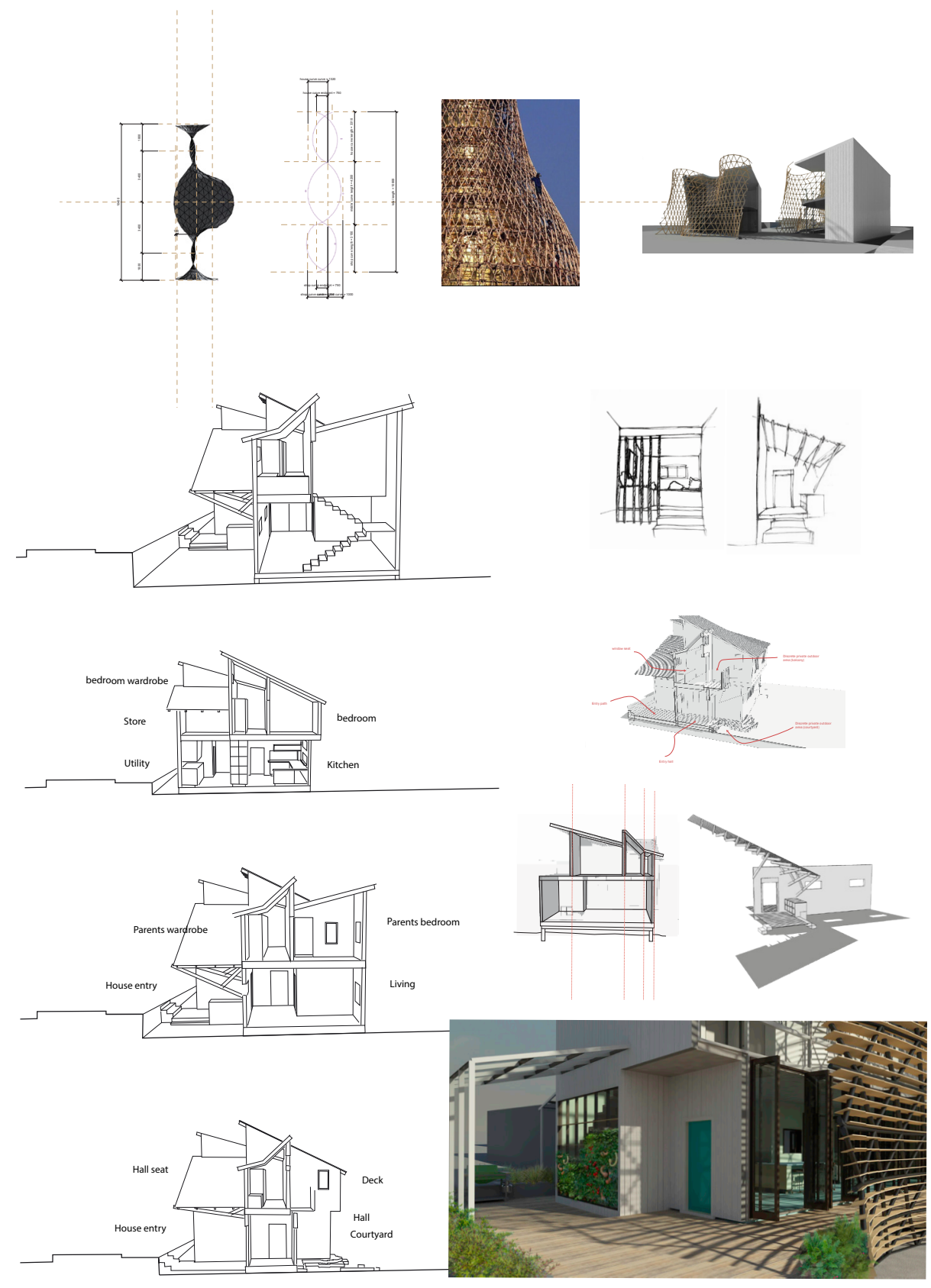

Figure 6.04

Circulation is particularly

- dwelling and business entrance important in a building that - where the dwelling and business contains multiple functions, meet for this reason this experiment investigates various liminal - communal to private spaces within the house zones: 
Design move 1.2:

shop-house on site
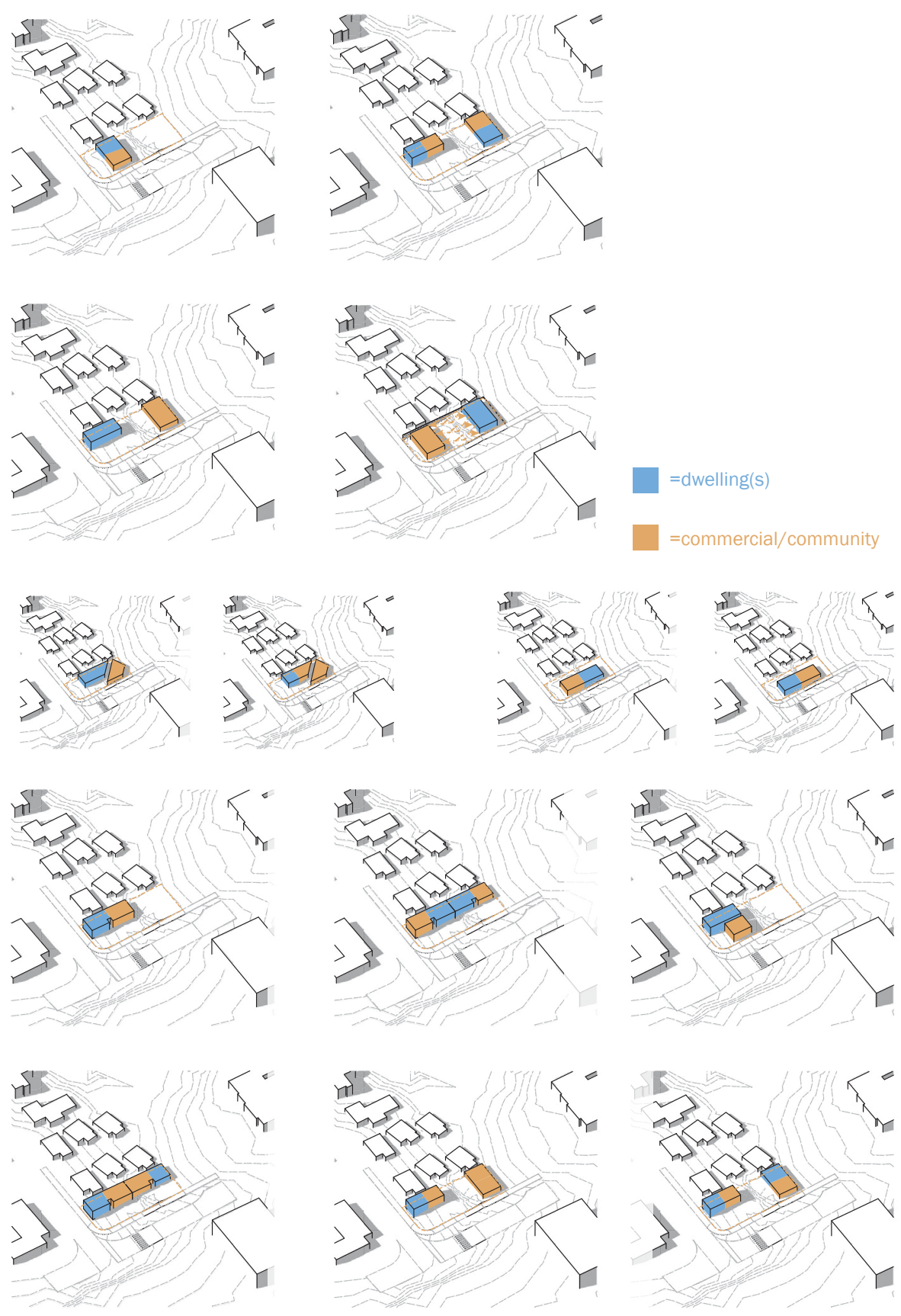

Figure 6.05

This experiment investigates how the various street

orientations of the shop-house

can be applied to the site. 
Design move 1.2:

The square and the backyard
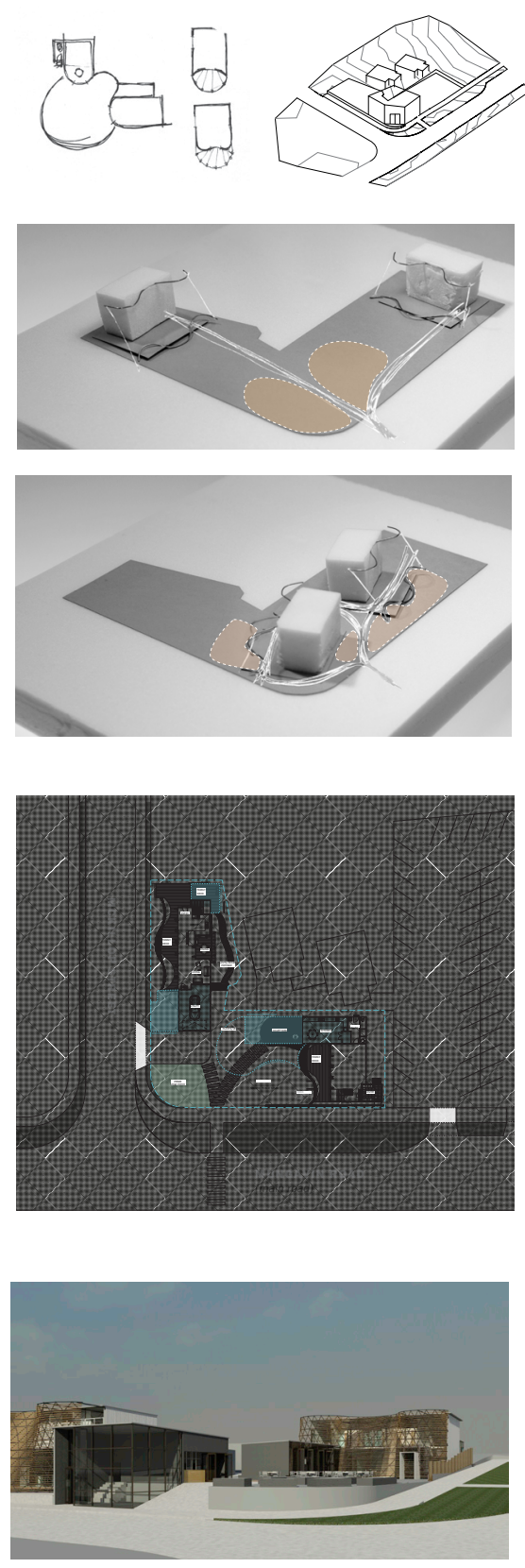

Figure 6.06

The mediating interface is used
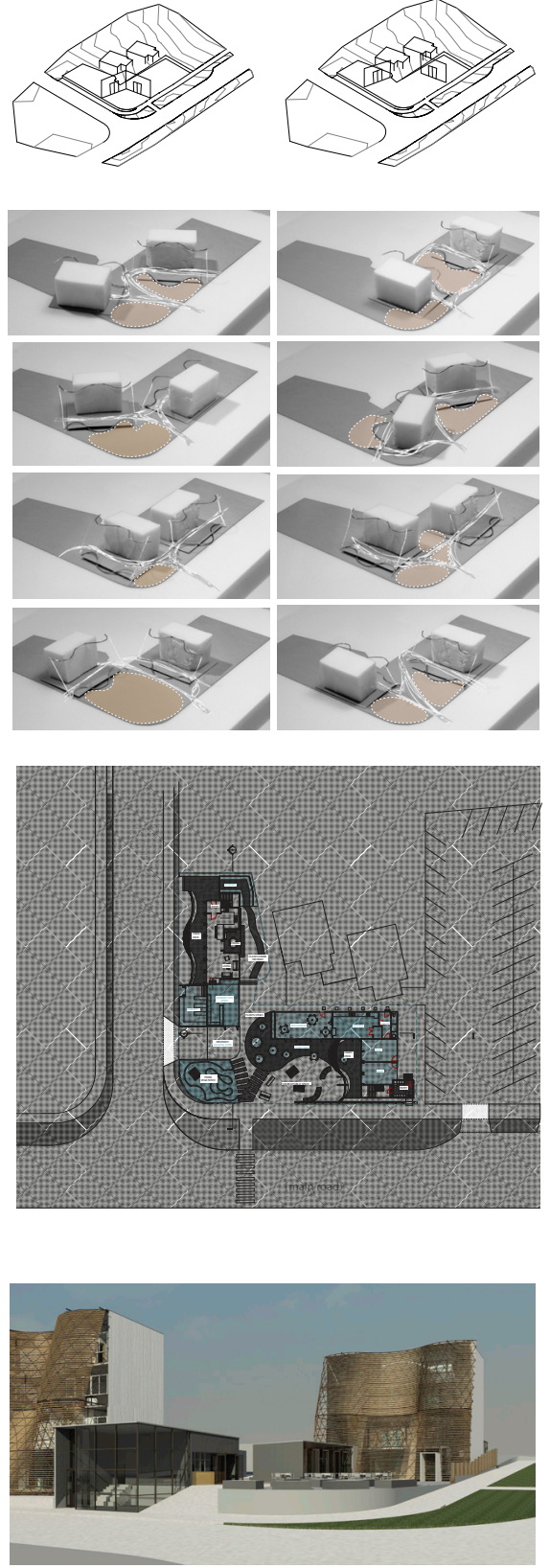

to create a public square from which businesses could grow. 
Design move 2.1:

the woven and the diffuse
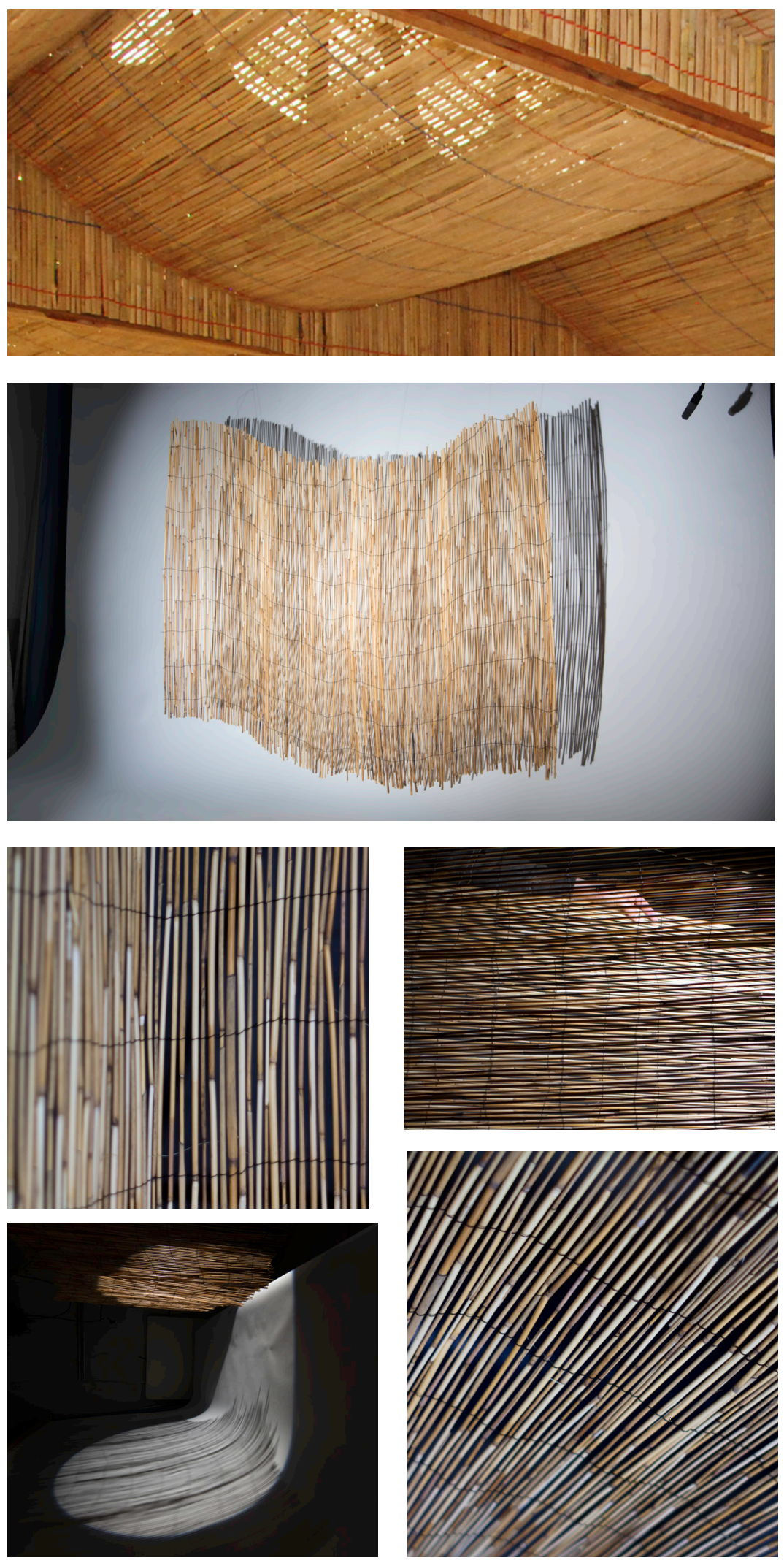


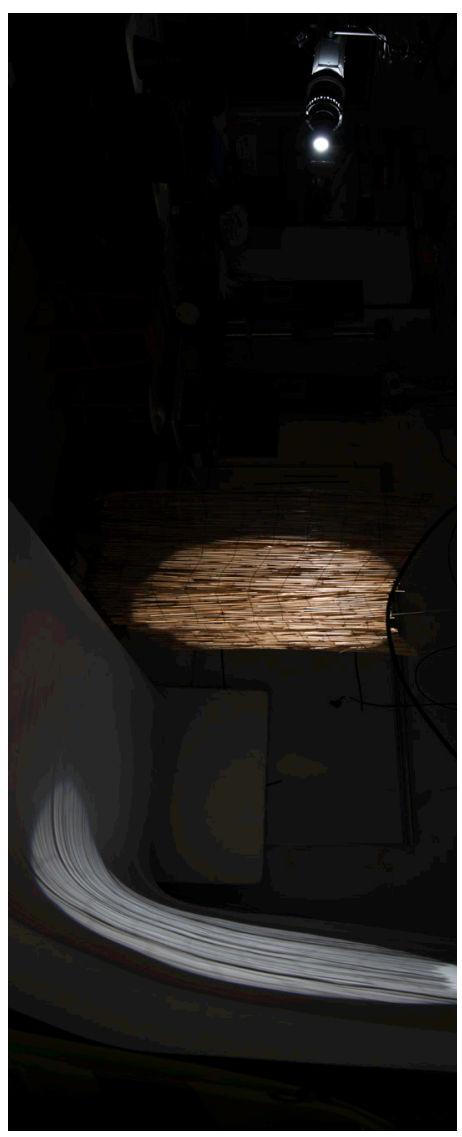

Figure 6.07

This experiment investigates how soft light can be diffused

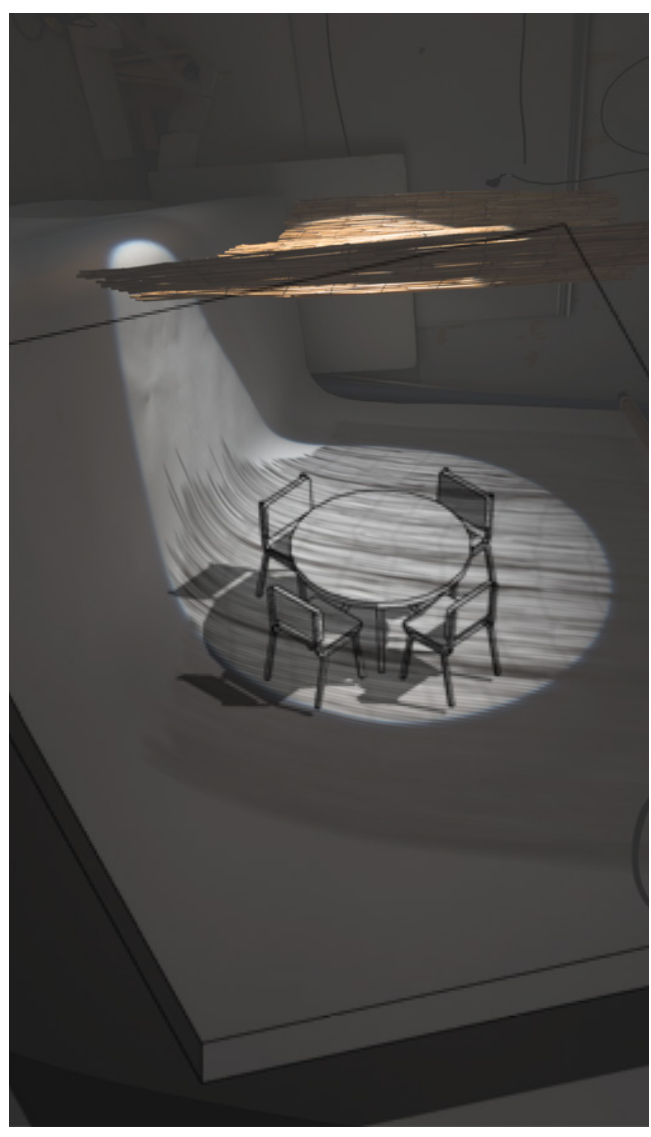

through a bamboo screen, as seen in High School Thazin. 

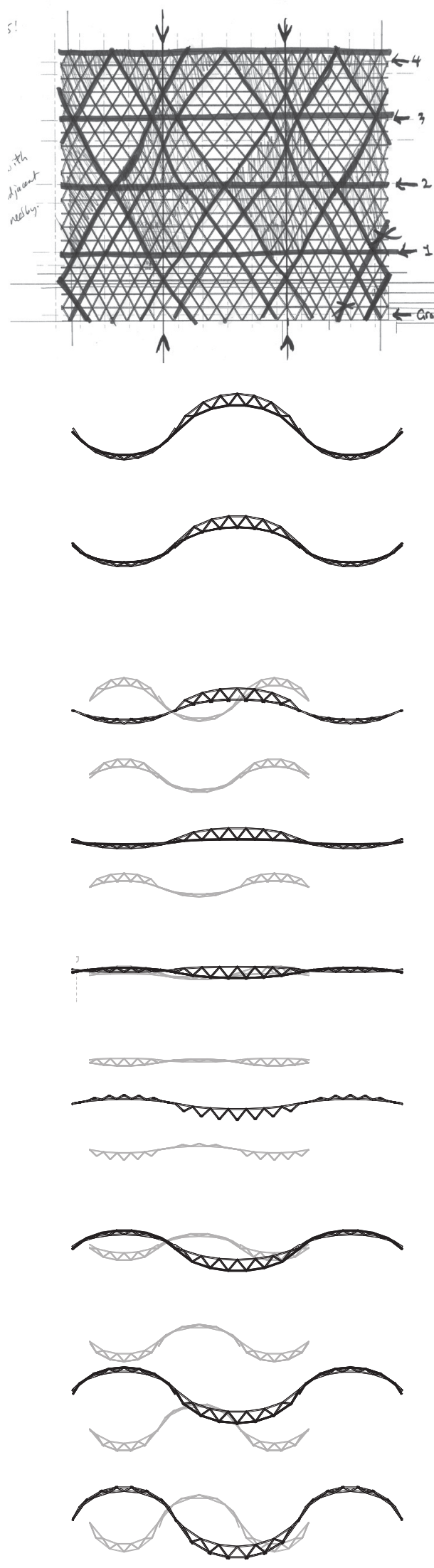

Figure 6.08

Explorations

of flexibility and permanent

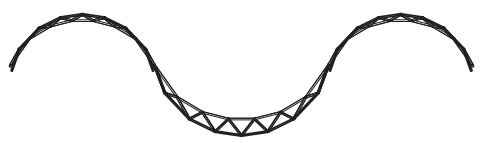

with the

interface. 


\section{Shop/house type 1}

This section investigates

developing the curved screen (figure 6.08) as a mediating interface between the private life of the dwelling and the public life of the business. This experiment places two buildings on the site, a shop-house for a Myanmar Ethnics family and a shop-house that could fit into a typical Pakeha setting. 


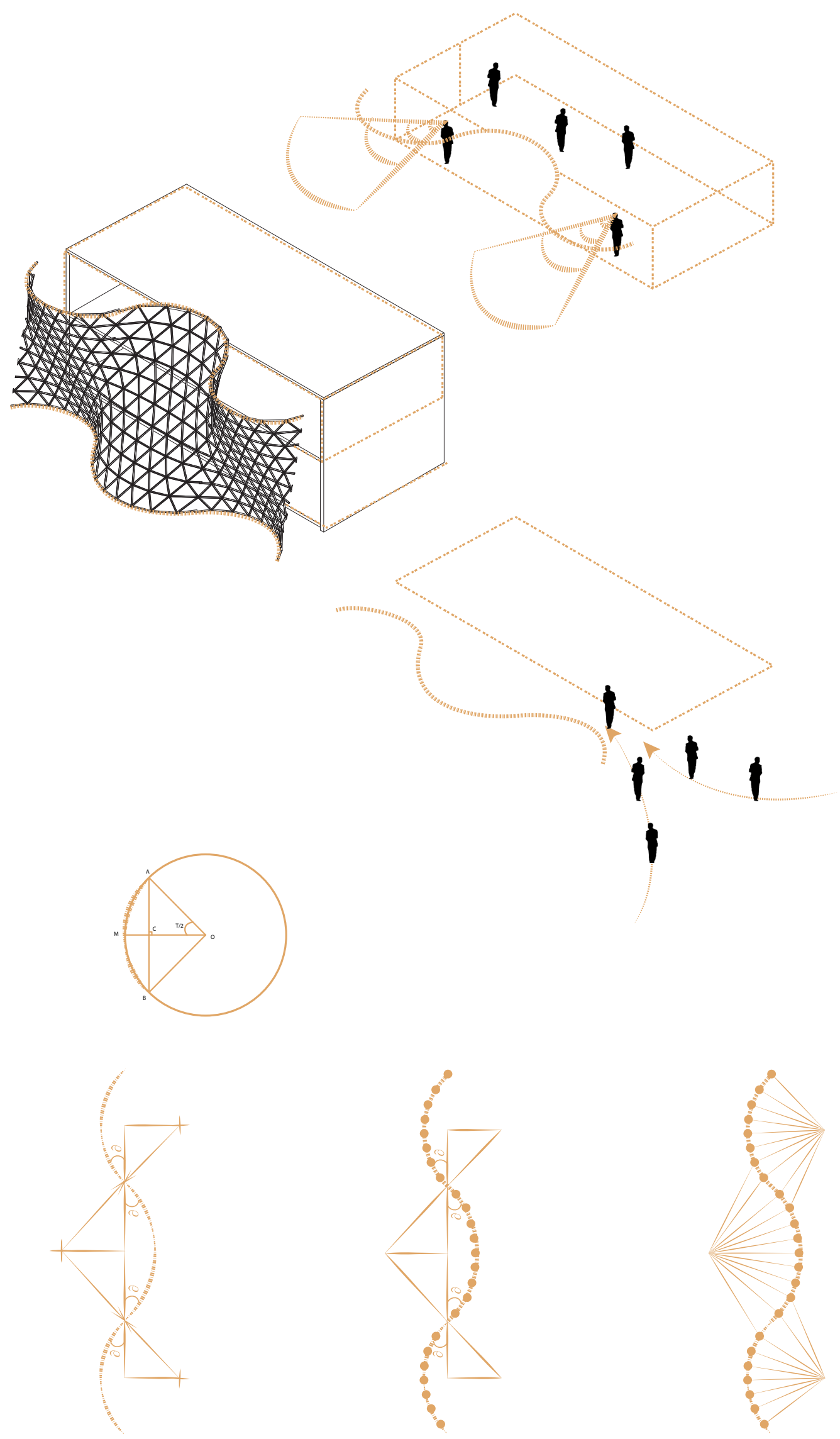




\section{Open for business}

The interface is designed to be open on the ground level where the business would be, and wrap protectively around the top of the dwelling (figure 6.09). This curved form can only manifest if the opposing curves connect at the same angle which is shown on the bottom left diagram. The mathematics of the curve are shown in the circle above. The bottom middle diagram shows the spread of the frame elements in plan, and the bottom right diagram shows how this form weaves through itself in plan. 

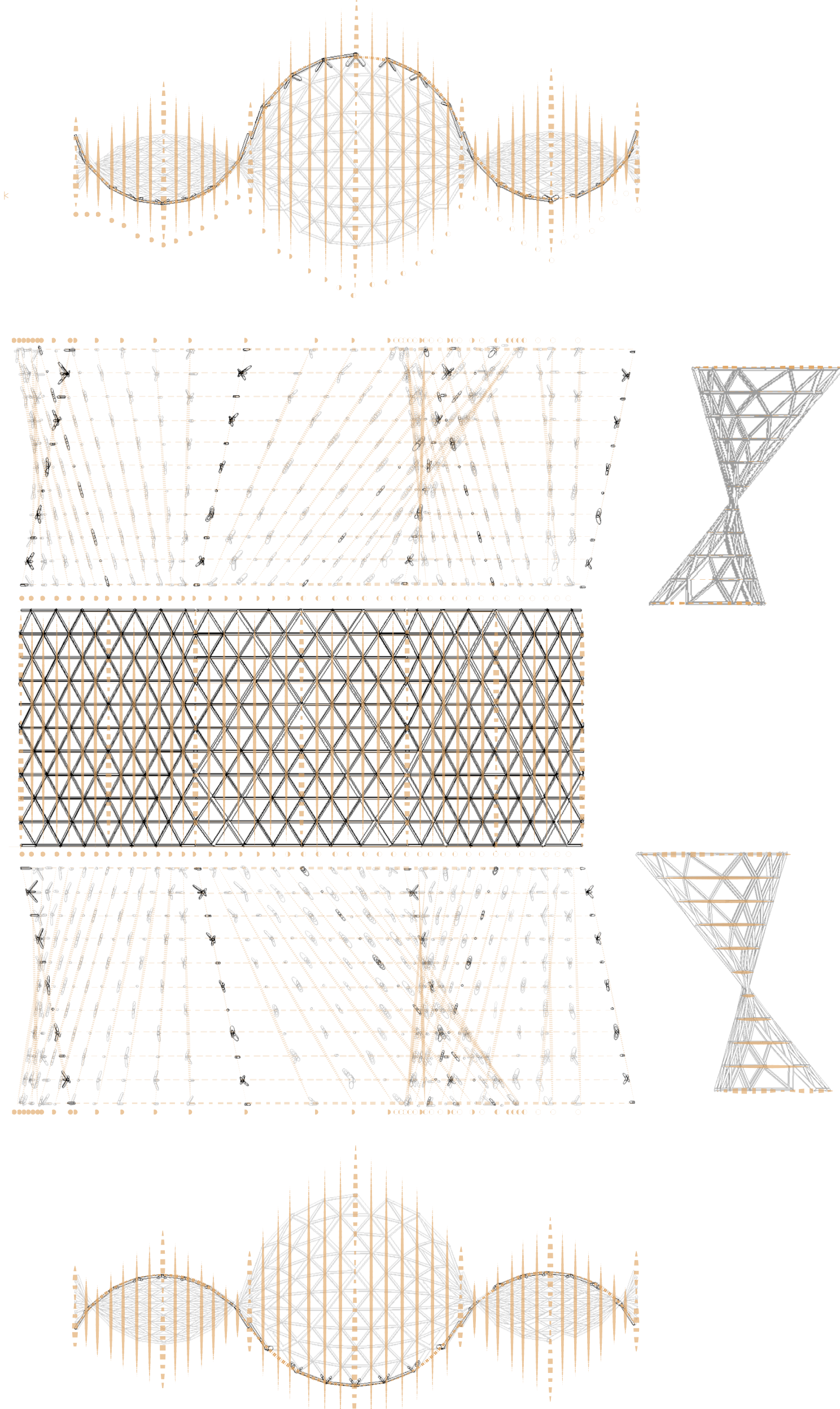


\section{Unique connections}

This image shows multiple sections sliced through the interface and overlaid in elevation (figure 6.10). This analysis shows that every connection in the frame would be unique.
The frame would be constructed in the same way as a geodesic dome, with each arm of the frame being connected with a pin-joint at meeting points. 

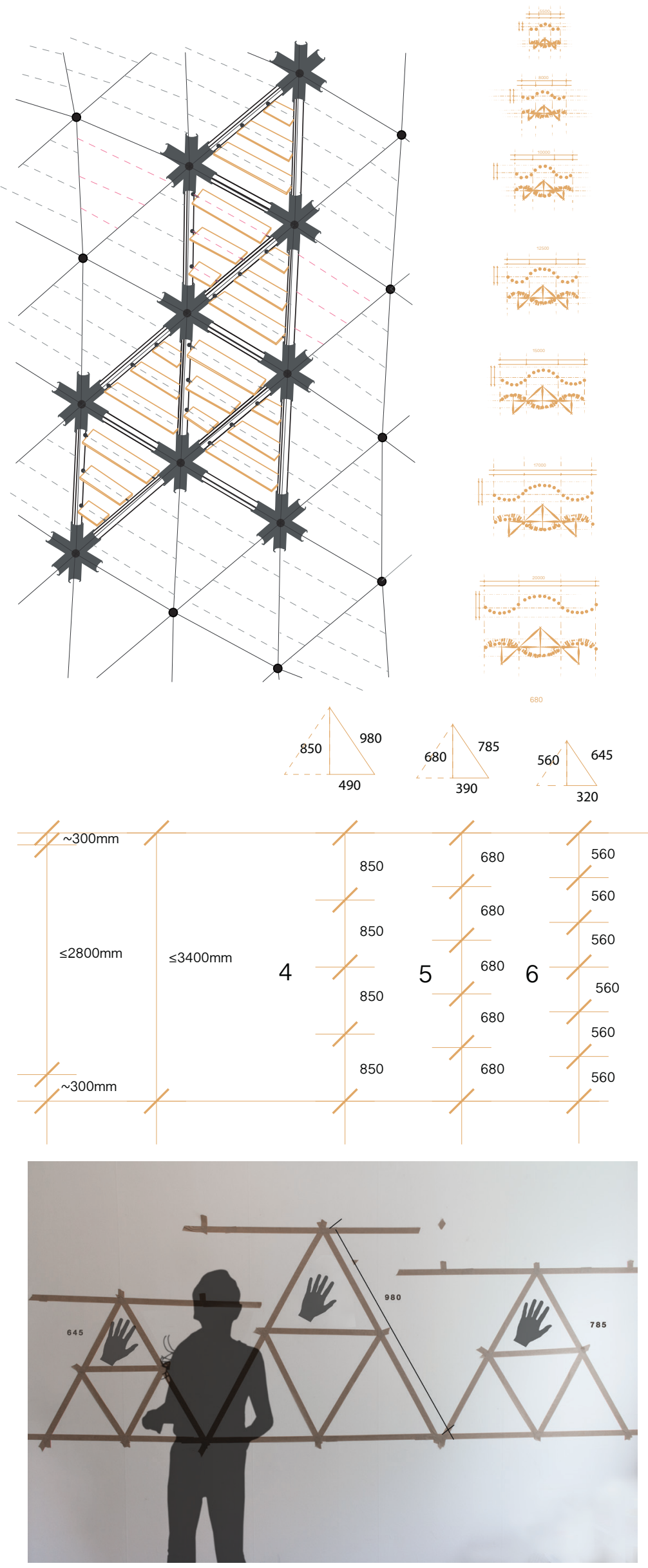


\section{Frame elements}

The interface's frame is

are tested to see if the curved constructed of connected form still looks curved, even when triangles (figure 6.11). Each triangle in the frame is the frame is shrunk down to $5 \mathrm{~m}$ across in plan. This experiment approximately the same size and should fit within floor heights, be too large for small children proves that these three sizes of triangle elements do not distort the curve of the form, even when to easily climb and be a suitable size for infill objects such as sun shades. Various suitable sizes the frame only stretches across a small distance. 

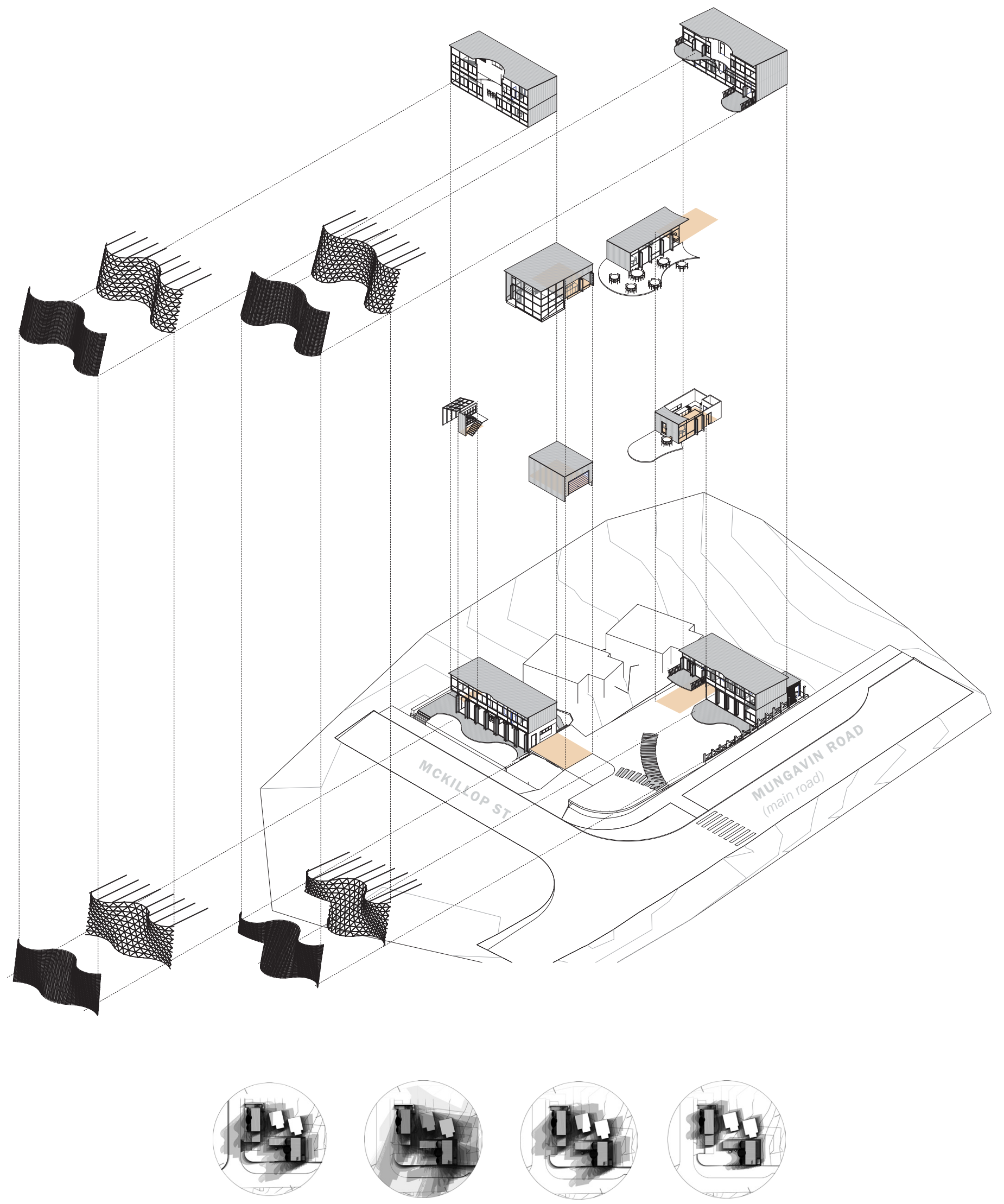

Figure 6.12 (above bottom) Shade maps at the equinoxes and solstices. (above top) an exploded axonometric investigates how the building could evolve 

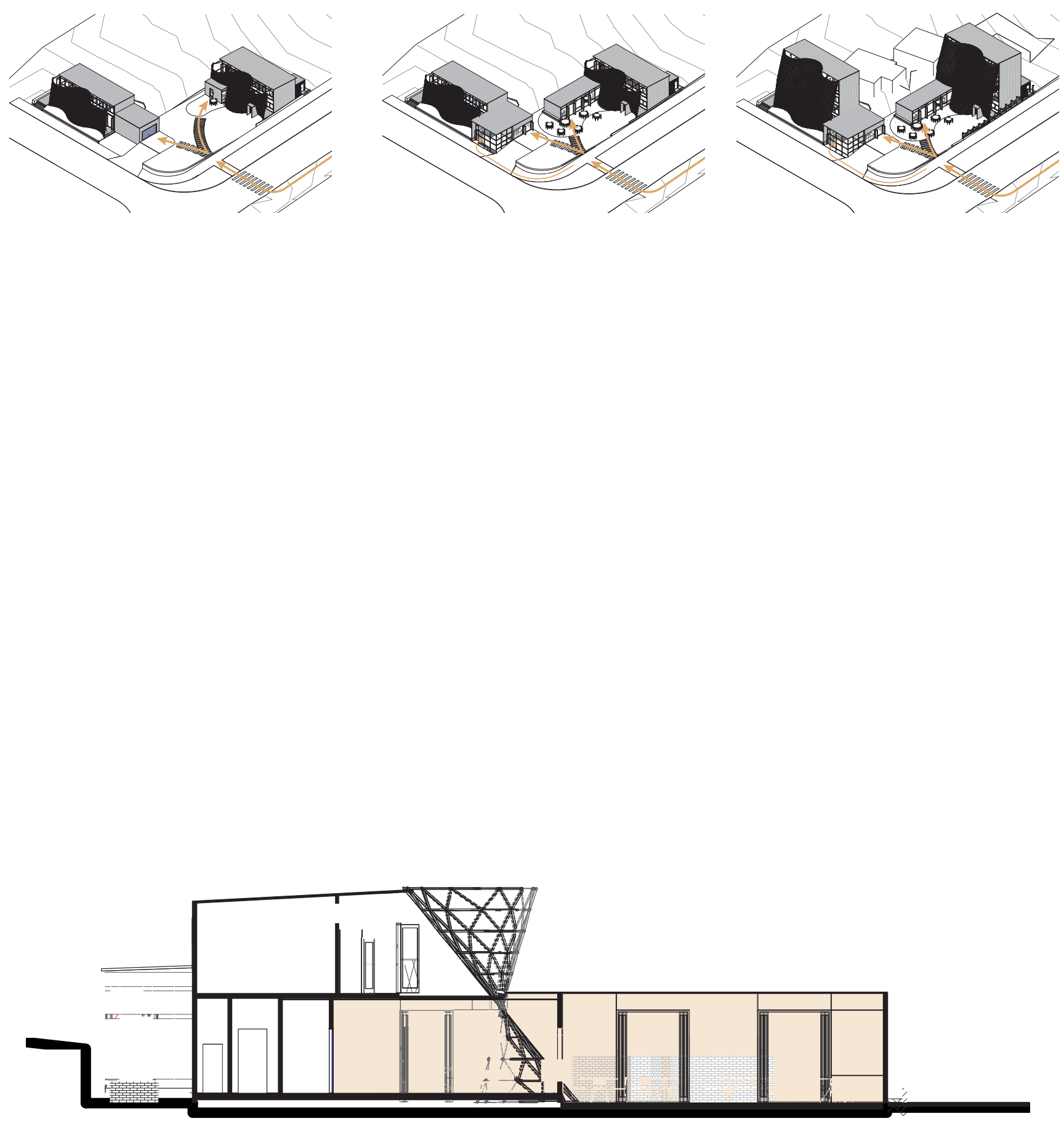


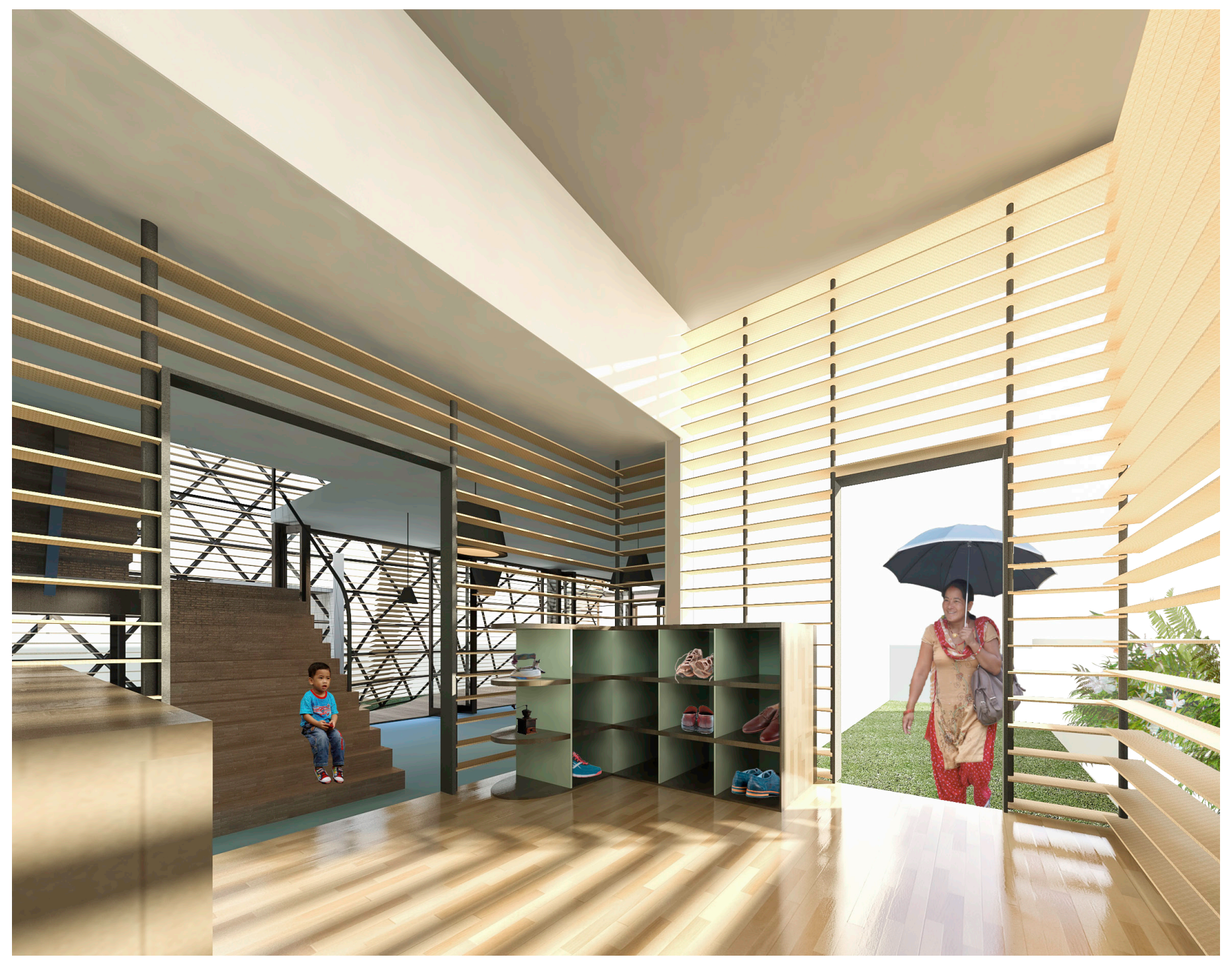

Figure 6.15

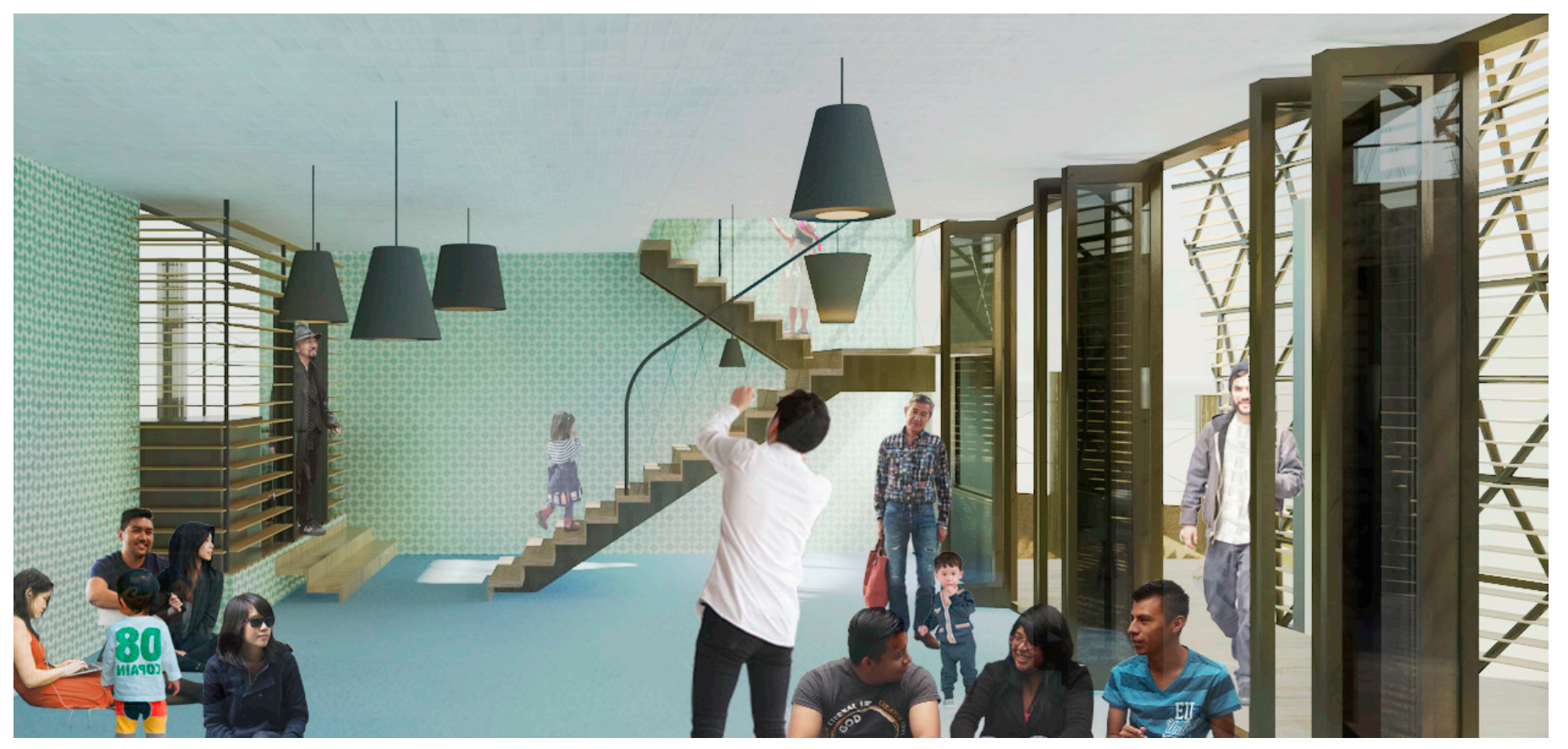

Figure 6.16

Living room 


\section{Entry foyer}

The entry foyer is filled with luckbringing morning light through an east facing front door. There are obvious spaces to take off

shoes, and plenty of opportunities to gaze into the living room or out to the street.

\section{Living room}

Through the entry foyer, the living room is a wide-open space which can accommodate many guests. Pendant lamps

create moments of illumination within this large room, so that it can become intimate at night if needed. 


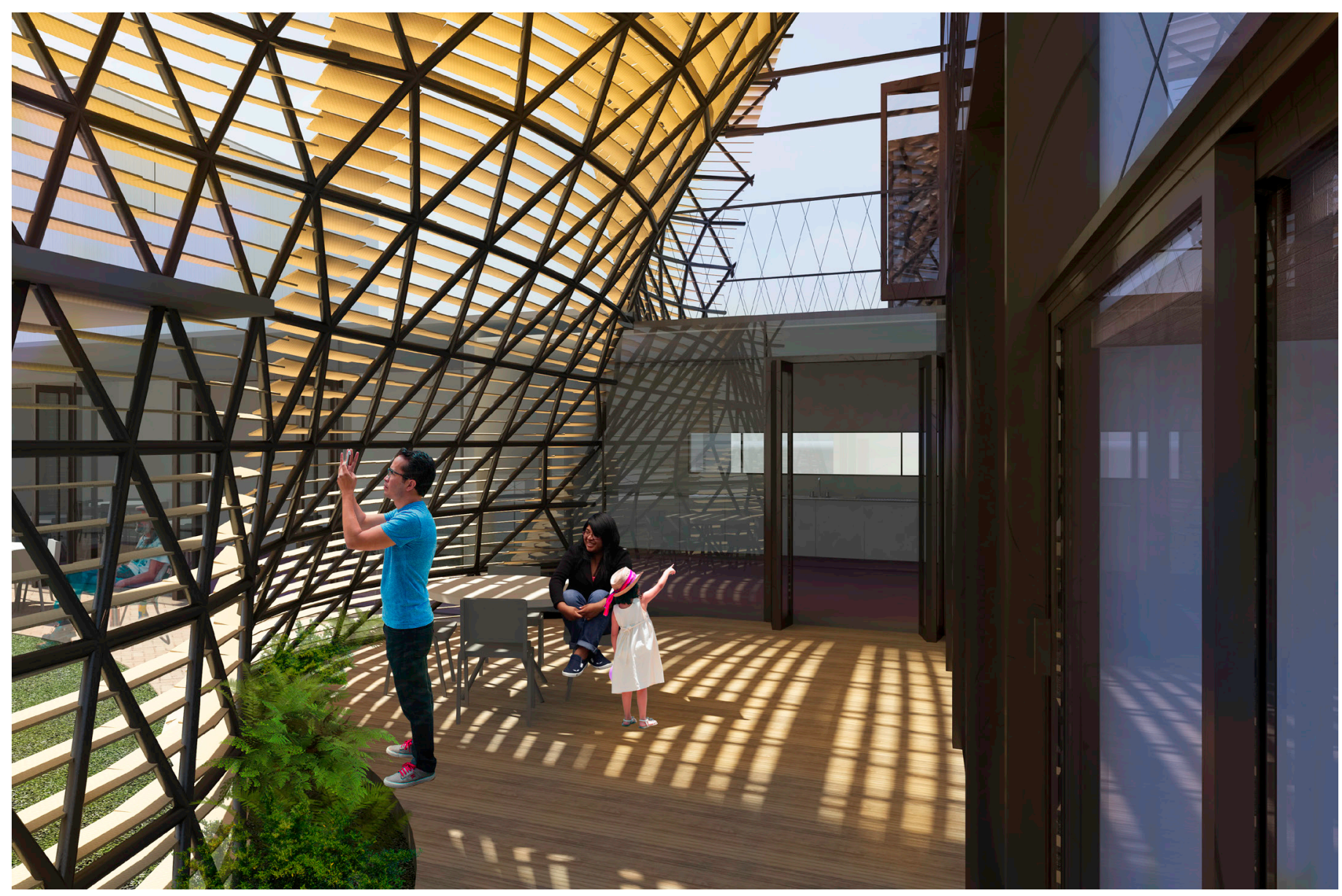

Figure 6.17

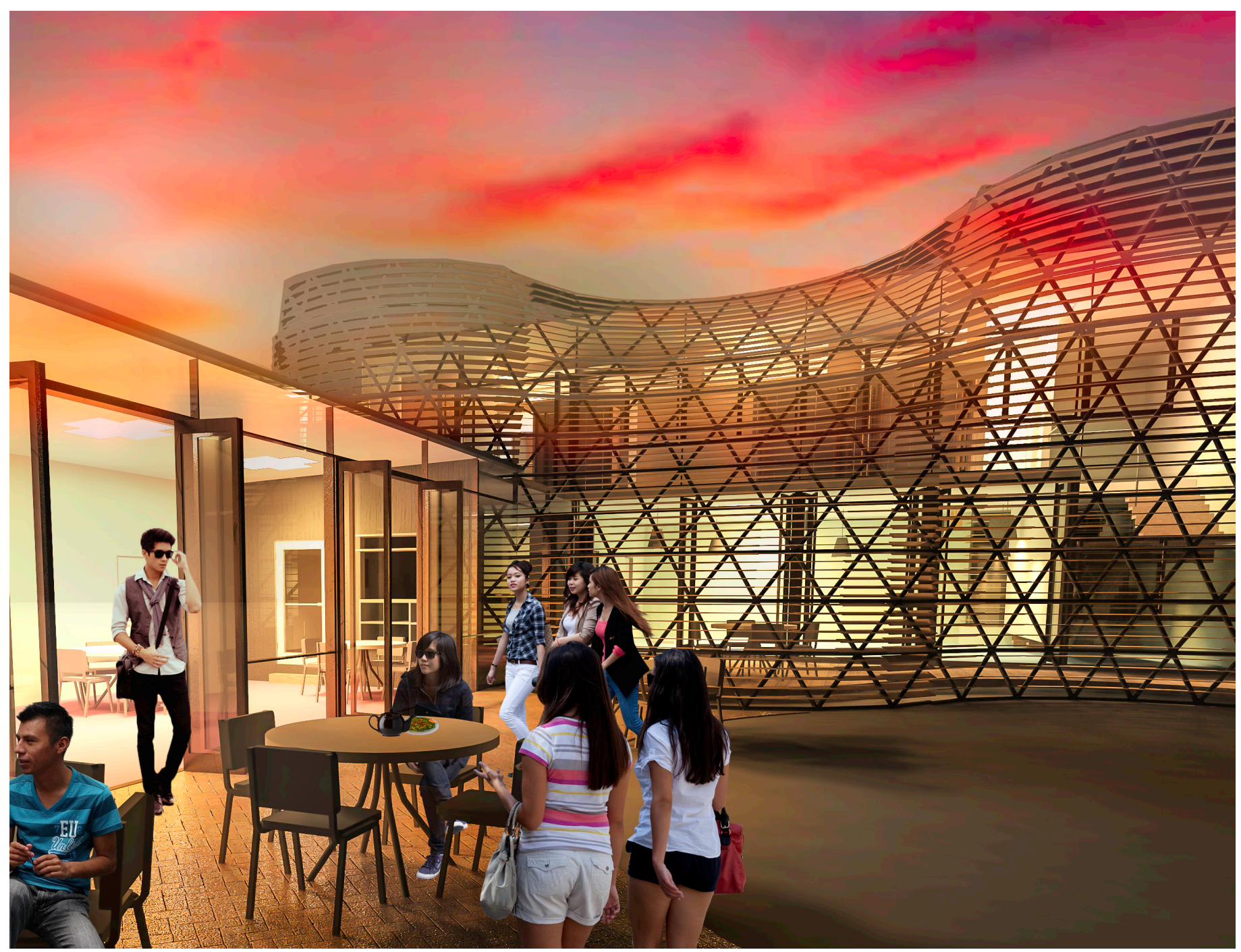




\section{Deck and interface}

North-west from the living room, ceiling-height doors open out to a private deck. Through another door, the deck is connected to

\section{Restaurant}

The kitchen protrudes through the interface into the central courtyard, which provides the the kitchen, which has a firstfloor deck above. This upper deck provides a safe place for children to play.

restaurant with a space to grow out from the house. 

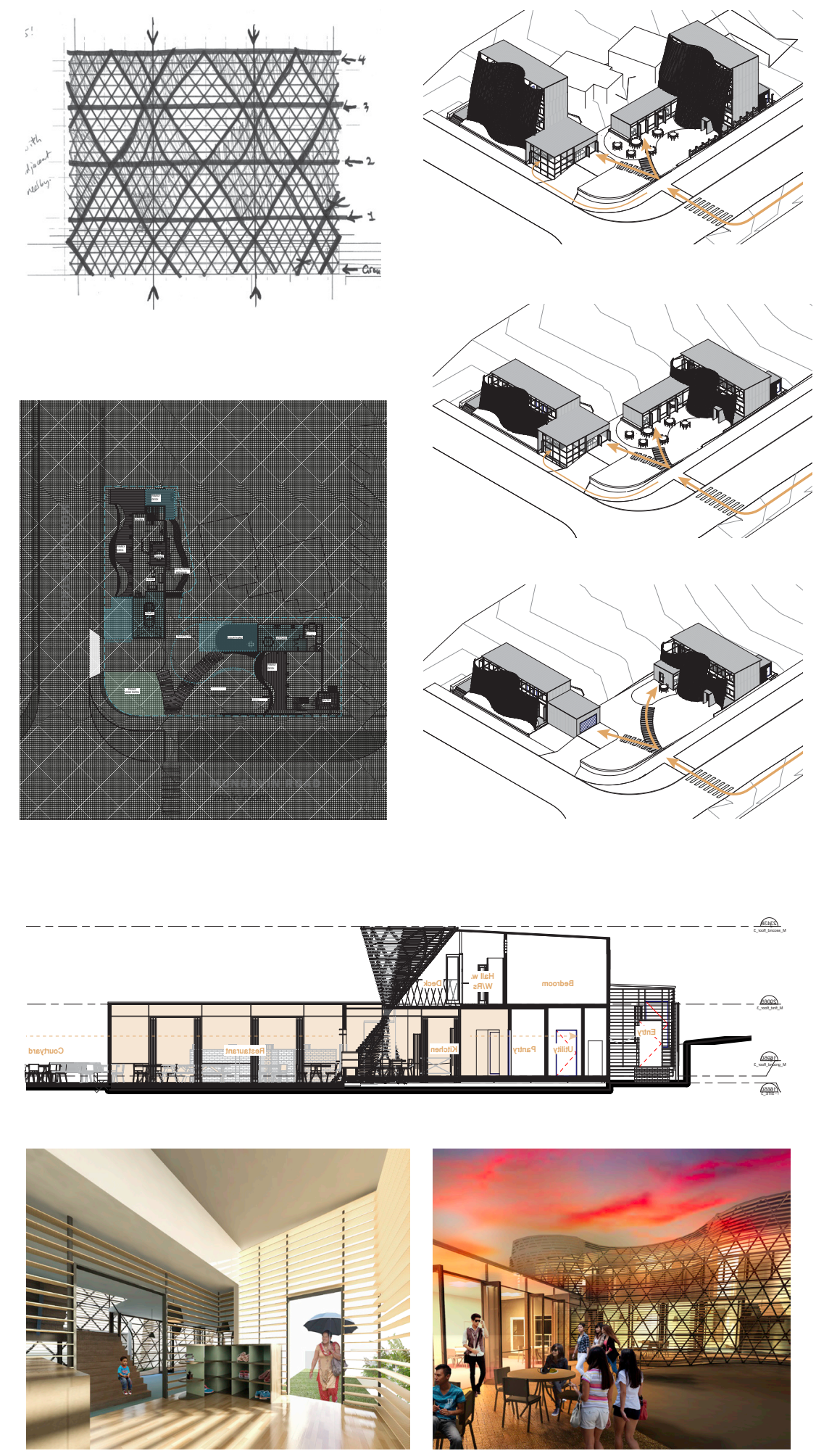

Figure 6.19 


\section{Reflection and final review}

Some major criticisms from the final review were:

- design does not connect well with its surroundings,

- there is not enough motivation for the people to use the public

space,

- these buildings could exist anywhere - why not show some more obvious architectural features from Myanmar architecture in the design? - the facade felt cage-like.

The major problem with the shop-house iteration is that this design is not meaningful in any specific way. As a form, it creates a barrier not an interface. The construction is too complicated which means that the architecture is not flexible, or even accessible. As a design, it does not create any identity specific to the Myanmar Ethnics. Even though the central courtyard offers plenty of potential space for the business to grow, the design does not do anything interesting with this space. While it was an interesting idea to contrast a dwelling for the Myanmar Ethnics with a dwelling that a typical New Zealand family could live in, the idea was not developed enough to be successfully manifested in the architecture.

With only two potential businesses on the site, there was not enough motivation for the public to use the space. Further exploration in how to get the wider community to use the site is needed, so that it can become a place which encourages intercultural interaction. 


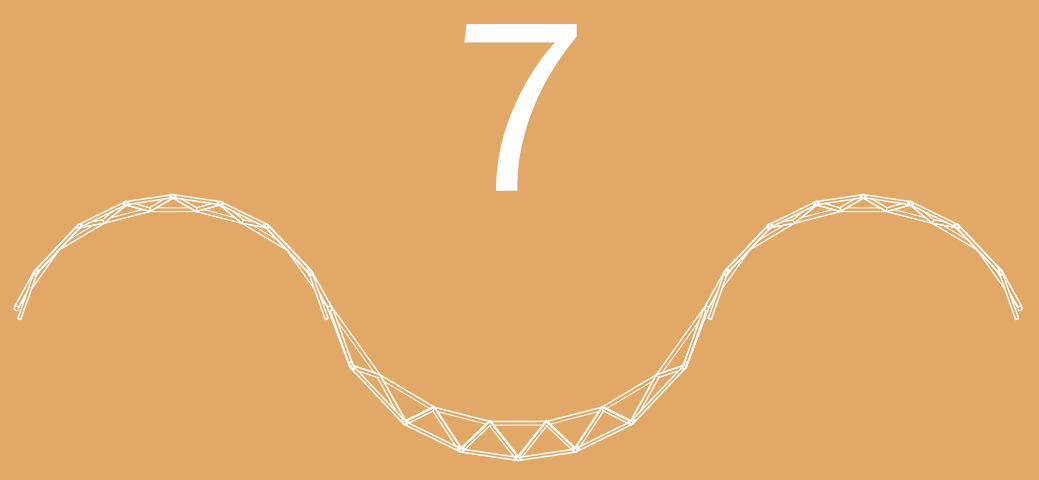




\section{Community interaction}

This section investigates and explores how a spatial intervention can encourage interaction between diverse members of the community. To achieve this, precedent reviews are conducted on interventions of a similar scale to this thesis.
To begin with, two international examples are investigated which will provide the information to explore a potential intervention which would bring wider community members into the site of Mungavin Avenue. 

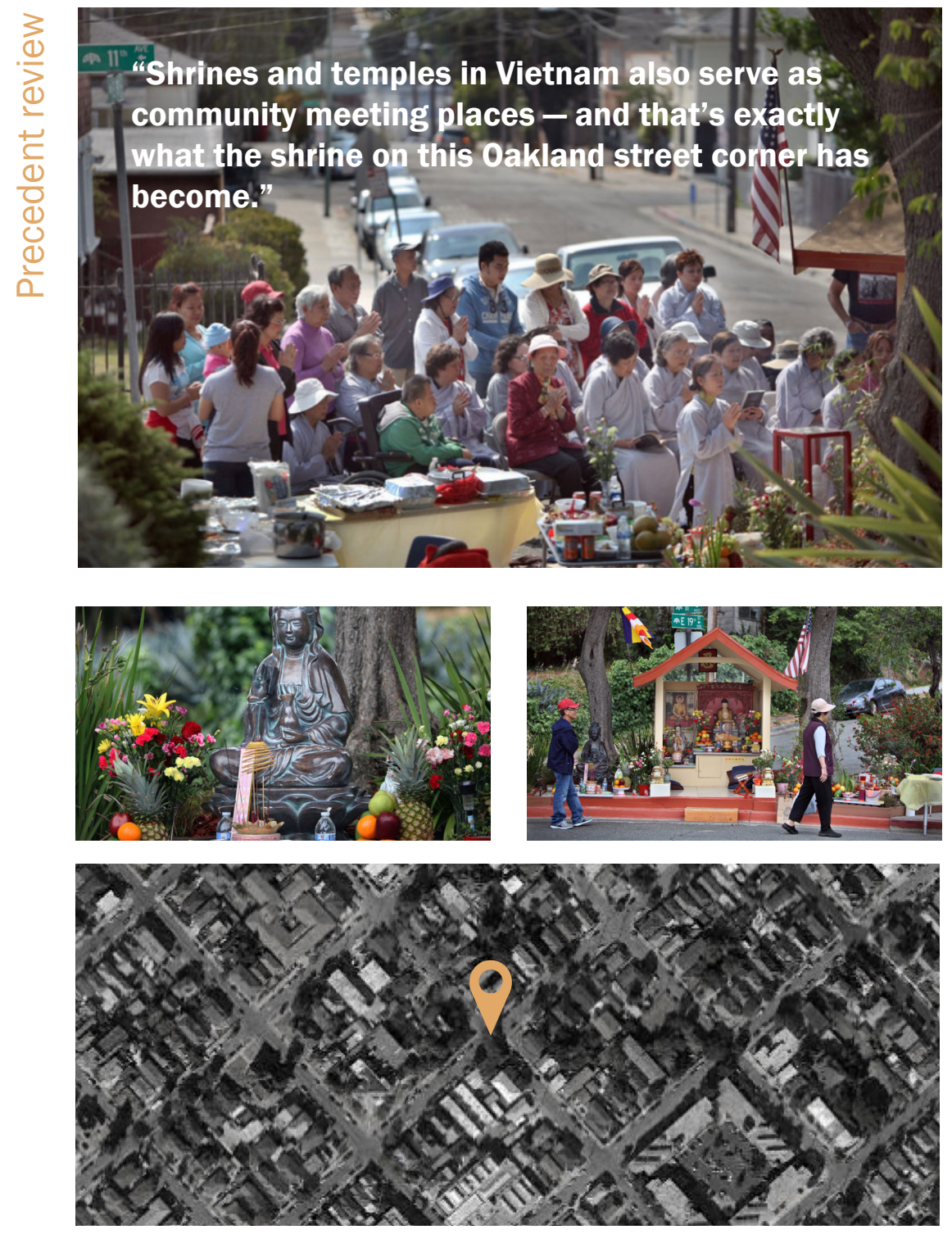

Figure 7.01 Oakland Buddha, photos by Thomas Walden Levy 


\section{Oakland Buddha}

In 2009, a resident of an Oakland (USA) neighbourhood wanted to find a solution to littering on a suburban corner and installed a Buddha statue. The statue not only stopped the littering but, the Buddha has been adopted by the local Vietnamese community. It has become a shrine and a gathering place.

This is interesting because it shows that a simple intervention to a space can become a node for the community if it has specific meaning to that community. 

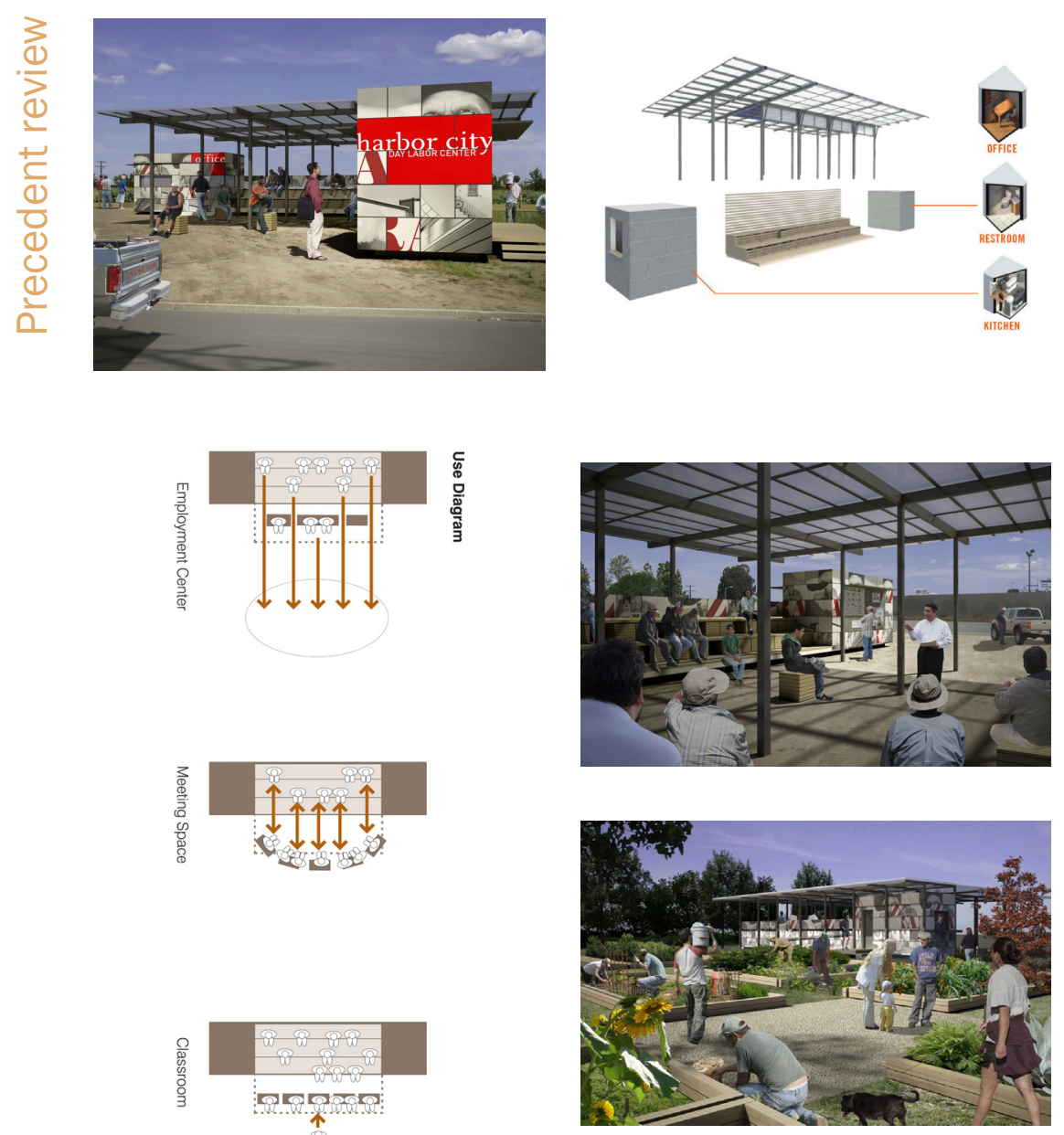

Figure 7.02

Day Labor Station, Images by Liz Ogbu 


\section{Day Labour Station}

Between 2005-2010, Liz Ogbu's Day Labor Station was tested in San Francisco (USA). There are many day labour workers who search for work each day in the USA and often end up occupying spaces meant for other uses such as street corners and car parks. These spaces generally lack basic amenities such as toilets, fresh water or shade. Liz Ogbu has created a design which is an examination of the bus stop typology. She has taken these basic amenities and created a small flexible space with an awning which shades a seating area which is then capped by two utility rooms.

This precedent shows that some spaces need to be defined, such as toilets and kitchens, but also that simple elements, like an awning with seating can create flexible spaces that are pleasant to be in and encourage people the linger and socialize. 

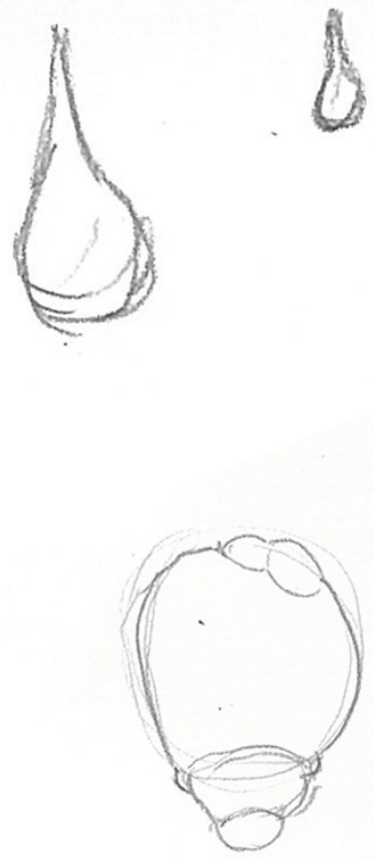

Figure 7.03 Early experiment thought sketches, water was always present during this thesis

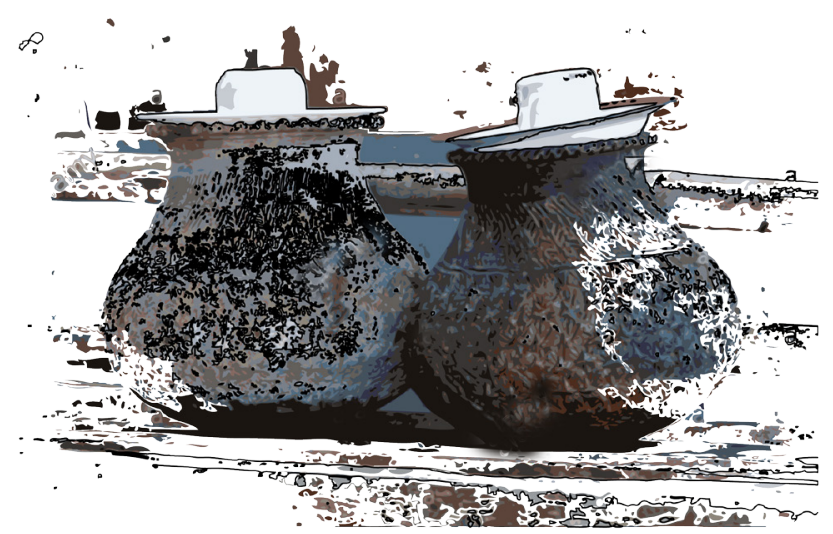

Figure 7.04 an image of the water jugs found in cities in Myanmar 


\section{Fresh water}

The Oakland Buddha and the Day Labor Station are two specific and highly contextual precedents. They are useful to look at different ways that community interaction can be created but they cannot be transplanted straight into New Zealand. For this reason, a contextually specific intervention is sought to create community interaction in Wellington.

This intervention must be able to have a specific meaning for the Myanmar Ethnic community and appeal to the wider New Zealand community. As an intervention with a specific meaning it can act as a metaphor and have a tangible element which would draw people into the space.

Water, and access to fresh water, is essential for survival. In Myanmar villages, the well is a place where people go to collect fresh water, meet and share stories. In cities in
Myanmar, filled water jugs can be found in public spaces for thirsty passersby. Water is an essential resource for growth. In this it is a powerful metaphor which represents ideas of new life.

A fresh water access site will be used as a device to bring the wider community together. It will be a public meeting place where people from all backgrounds will go to collect this vital resource. The fresh water access site will act as a gift from the Myanmar Ethnic community to the wider community.

In Wellington, there are two successful fresh water tap-sites: Te Puna Ora Spring in Petone and Thomson Lewis spring in central Wellington. There are no springs or fresh water access sites in Porirua which means that this thesis's fresh water tap-site will collect and utilise rainwater as a fresh untreated water source. 

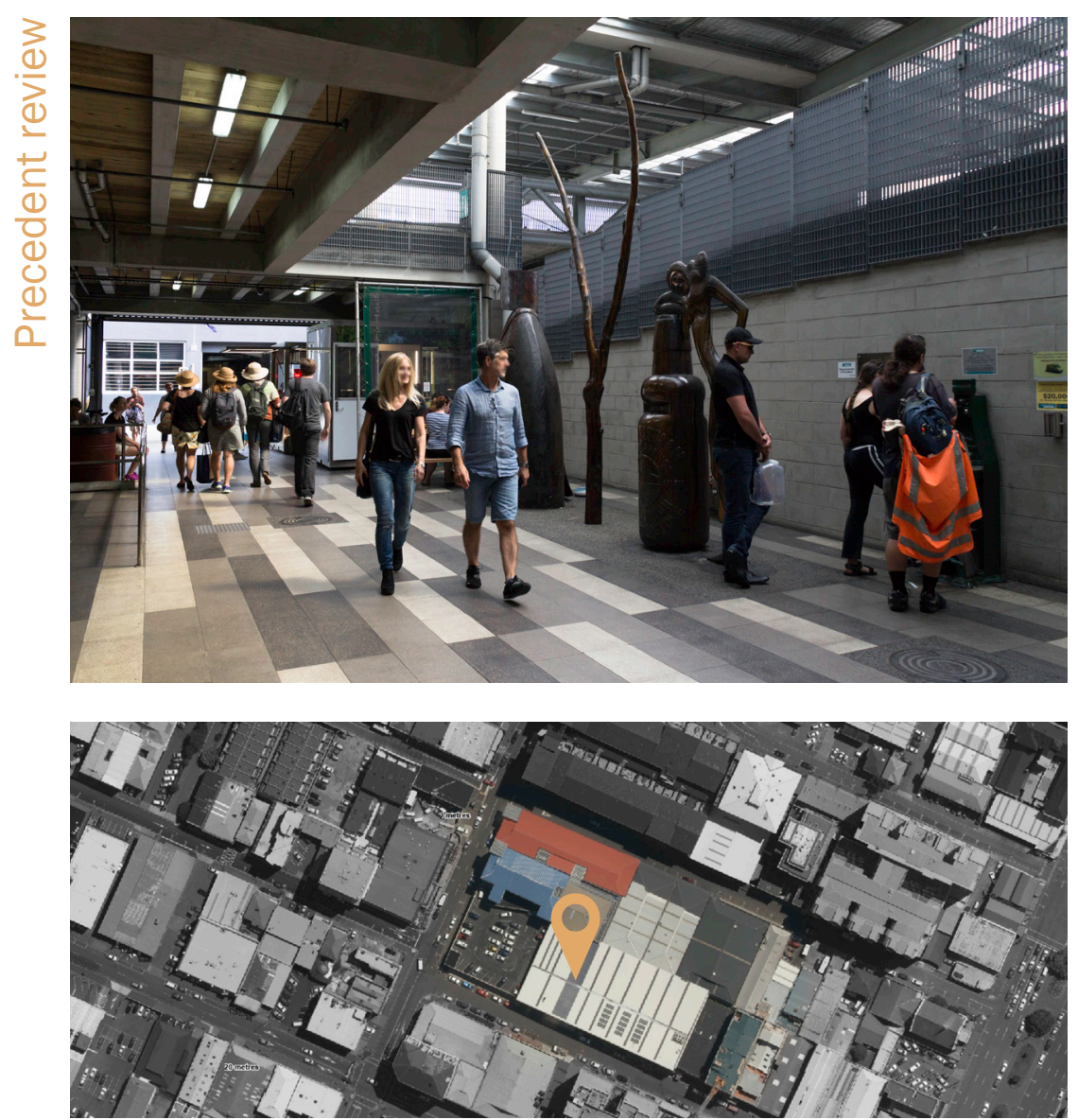

Figure 7.05

Thomas Lewis Spring on a typical weekend 


\section{Thomson Lewis Spring}

This spring provides artesian water under the bowered walkway within the Moore Wilson market complex. The walkway is situated between two city streets and connects the different sections of Moore Wilson's markets. It contains food carts, seating, sculpture and a public tap-site for the spring.
This precedent shows that even a narrow walkway can contain a multitude of uses, which are brought alive by both the functional elements, such as the food carts, the market and the tap-site, and by the decorative elements such as Paul Dibble's sculpture. 

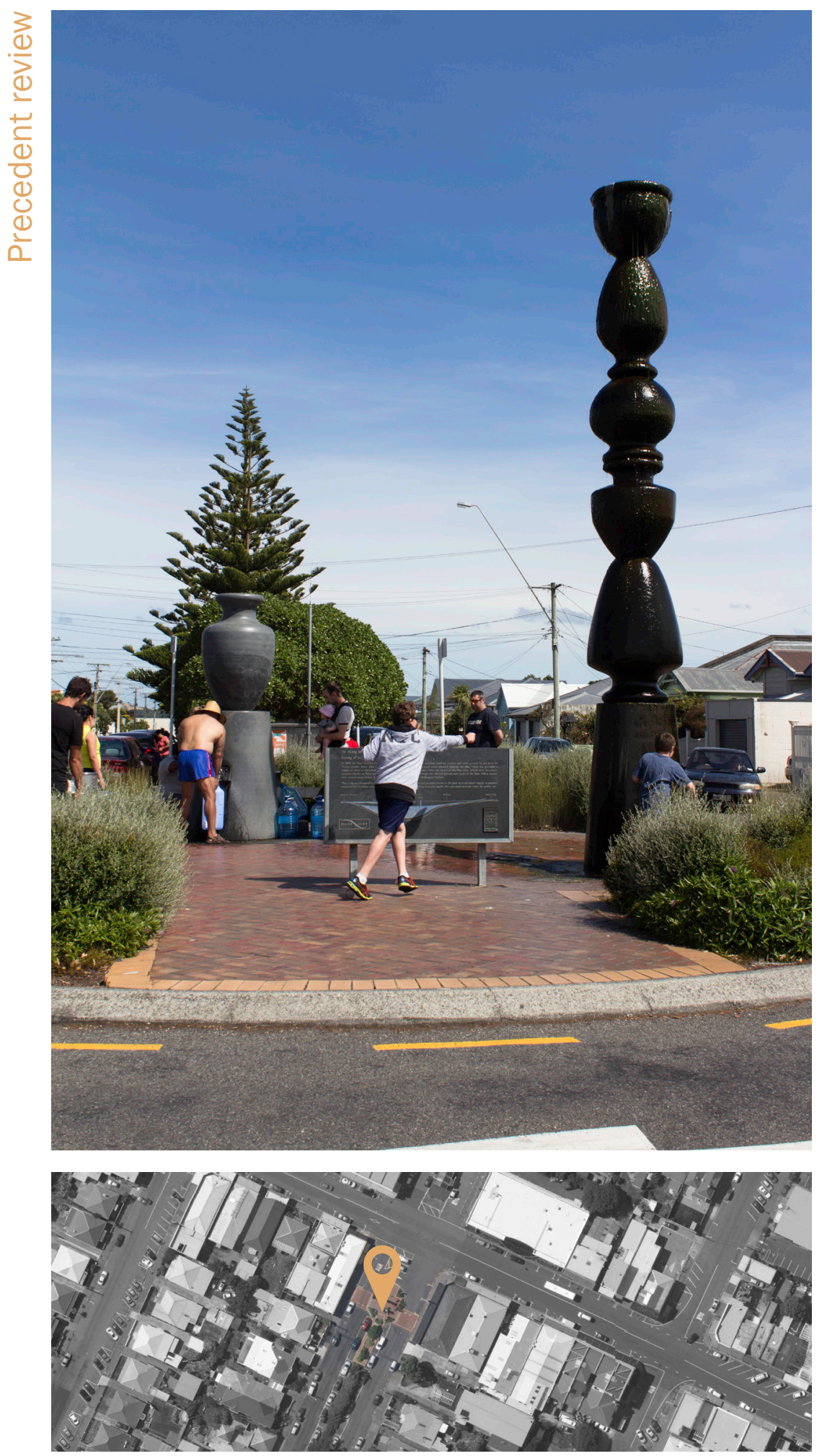

Figure 7.06

Fun and play is found at Te Puna Ora 


\section{Te Puna Ora}

This spring is located in Petone's tap-sites which people can gather main street. It is surrounded around.

by houses and has adequate carparking. Early in the morning, workmen stop by and fill up their drink bottles. During the weekend, the space becomes lively with community members arriving to collect their weekly supply of fresh water. The spring is outdoors, subject to the weather, and has multiple

Te Puna Ora acts as a place which brings the wider community together and has become a public meeting place. A site of fresh water has become both a stop off point in a journey and a site for play and connection during the day. 



\section{Reflection}

Water is vital and important to everyone. A fresh water access site could potentially act as a meeting place between the wider community and as a place of meaning for the Myanmar Ethnics community. The wider community would be motivated to visit the site and the Myanmar community would have a gift to share. This could occur through a space which would be designed to their specific cultural and spatial needs and, as such, would be a place from which they could share their culture and integrate into the wider community.

These interventions show how: - a space can become a node for the community if it has a specific meaning and benefit attached, - some functions need specific spaces while others can be more flexible,

- a narrow walkway, which is located between many sites, can become an active place where events occur if there are enough interesting elements and, - an outdoor space can become both a practical and playful destination. 


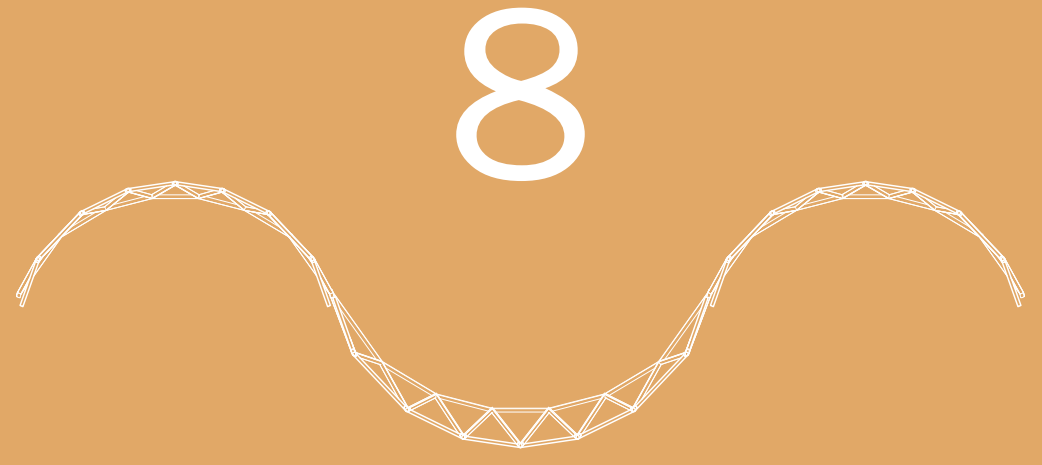




\section{Developed design}

This section takes the information learned throughout the research and iterative design experiments and applies it to a developed design process. 


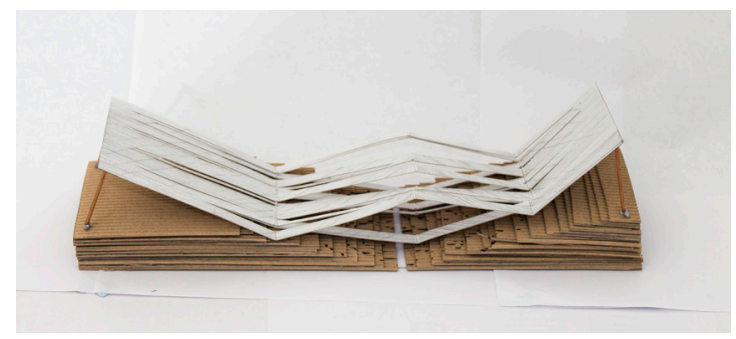

Figure 8.01 An early model exploring

connection

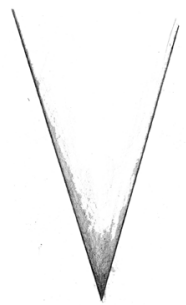

Figure 8.02 A sketch investigating the moment of connection as a weighted point. The aim of this is to spatial manifest water as a solid and persistent weight. Water has become another moment of permanence within this thesis.

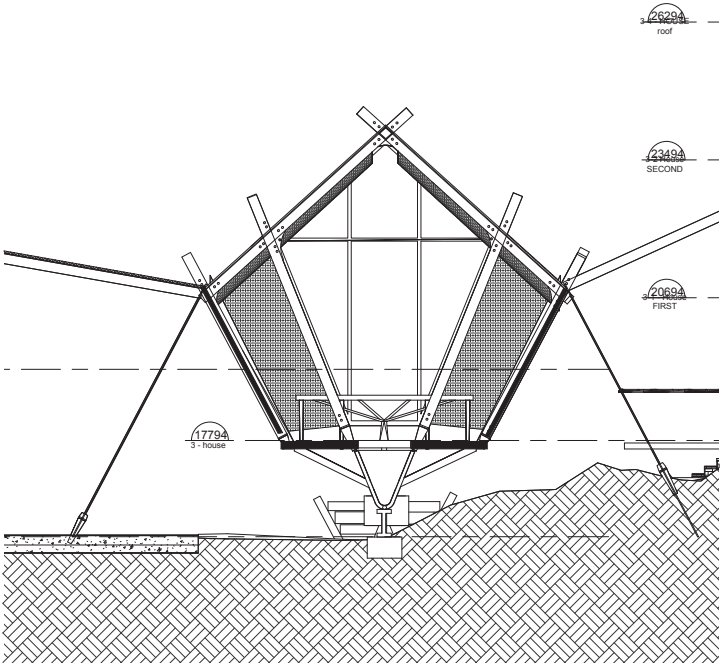

Figure 8.03 Water flows into the tank from connected roofs with a persistent rhythm to form a shape which point down. Also, water's life giving properties are acknowledged in the form as it draws the eye up.
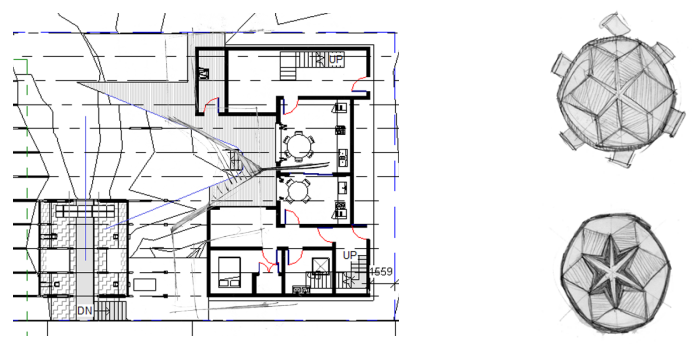

Figure 8.04 Other experiments into creating a persistent central point. 


\section{Moment of connection}

As an intervention that connects the functions and uses of the site, the Rainwater Well is visually expressed as two things joining in a point. This place is both a space where things meet and acts as a mediator between the dwelling and the commercial function of the kitchen. As a mediator, it also creates active points under each connected roof.
This expression of things joining is also seen in the two kitchens on the ground floor and on the shared moments that occur at a circular table. The table is designed as a circular object which accommodates different people. 


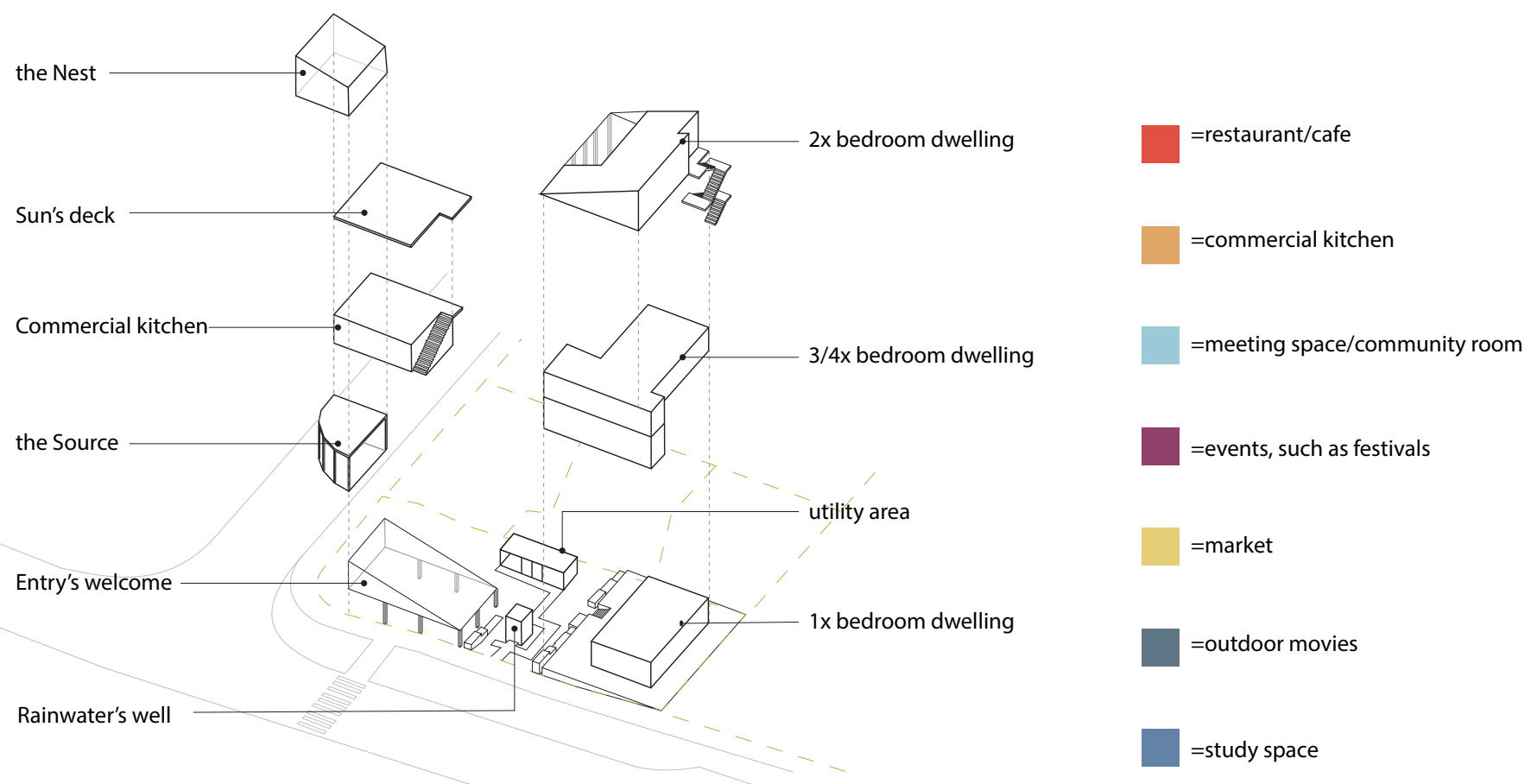

MON TO THURS

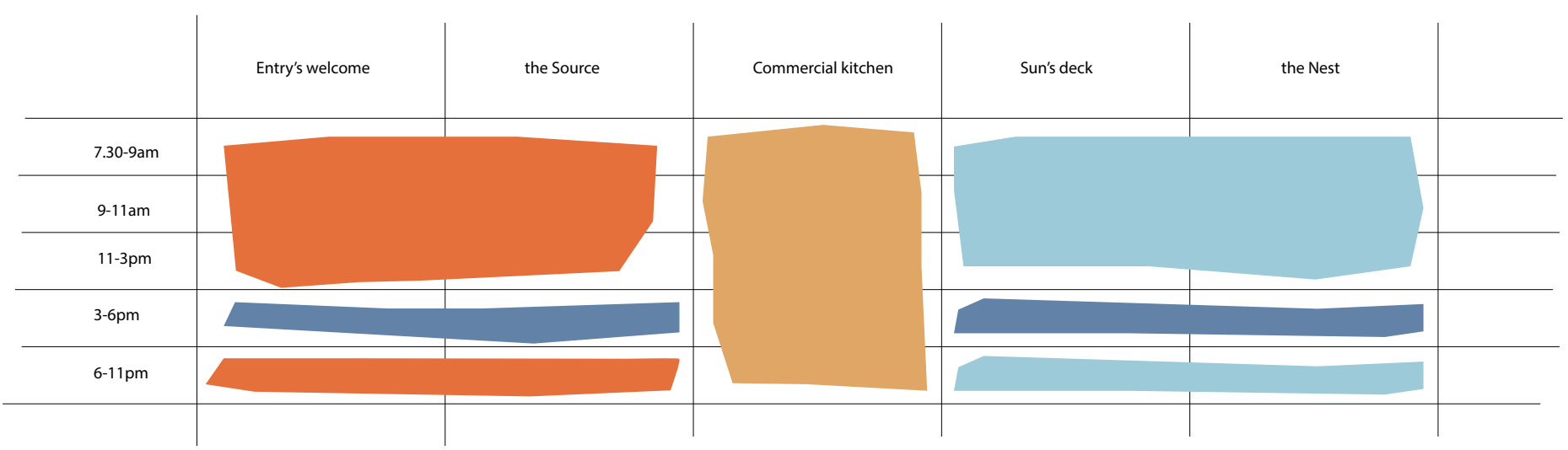

WEEKEND

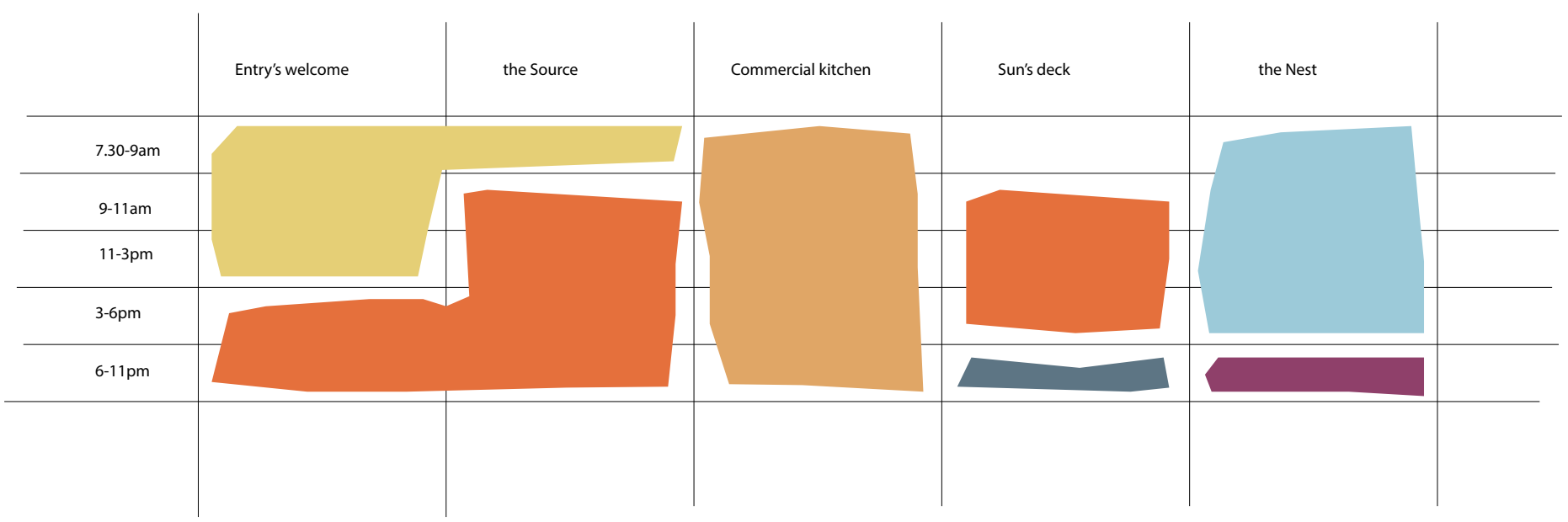

Figure 8.05 A time-stacking chart, to create a multi-tude of flexible potential opportunities. 


\section{Time-stacking}

Functional flexibility is tested through time-stacking diagrams applied to chosen spatial layout, which investigates how adaptable and flexible the design could be. This page shows the spatial key with the timestacking chart. The next page shows the chosen functions on the spatial key. 

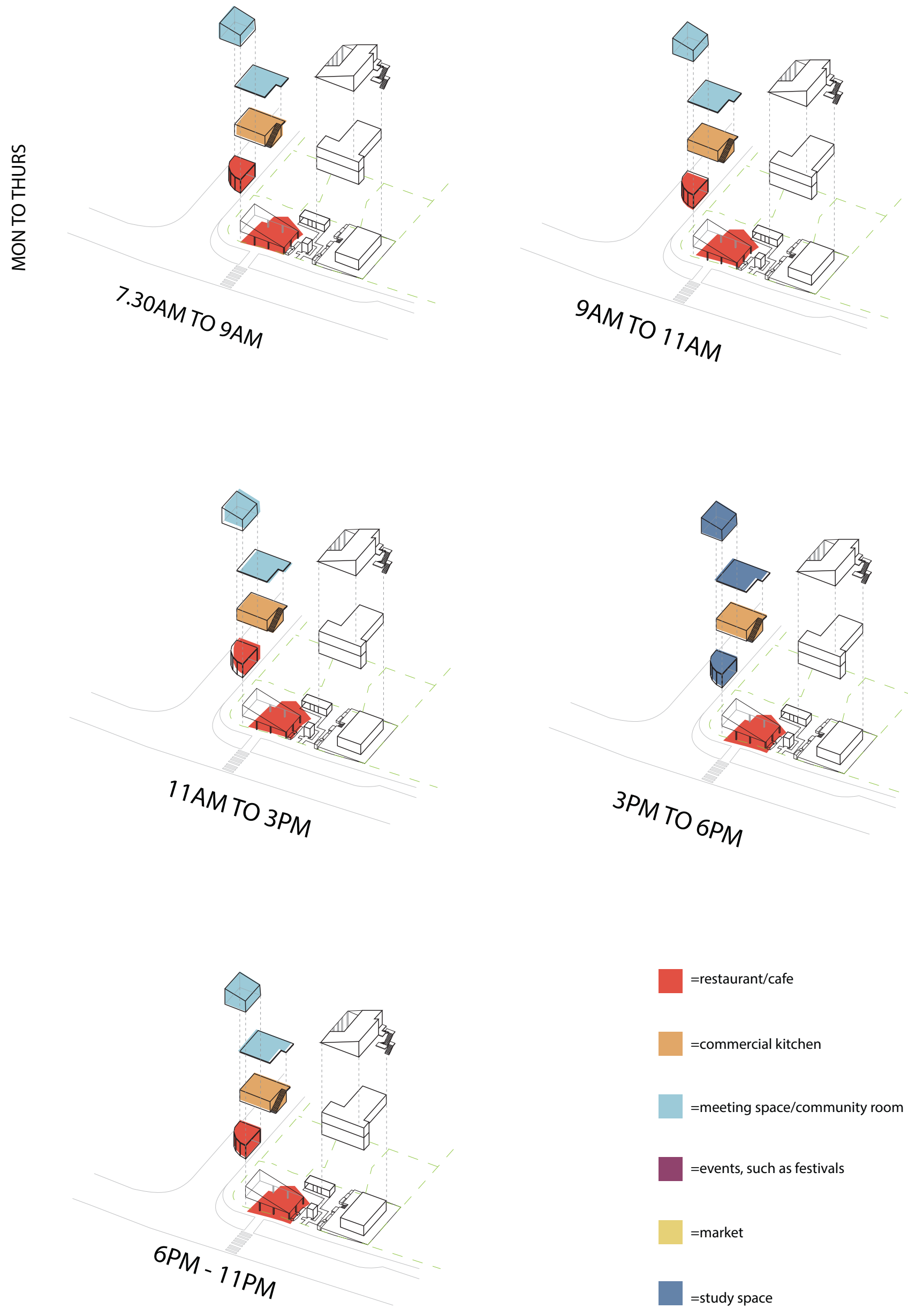

Figure 8.06 


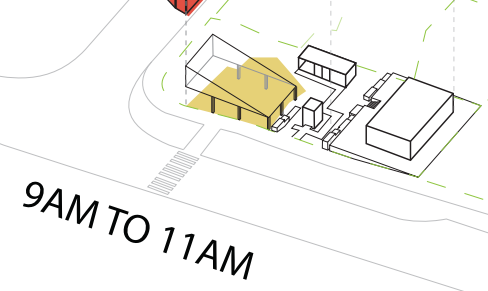

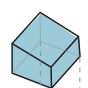
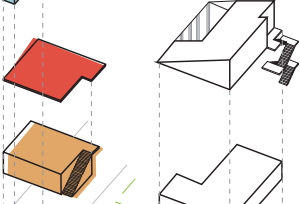

1

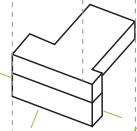

ar

Nons

${ }^{17}$ AM TO 3 PM

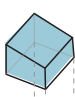
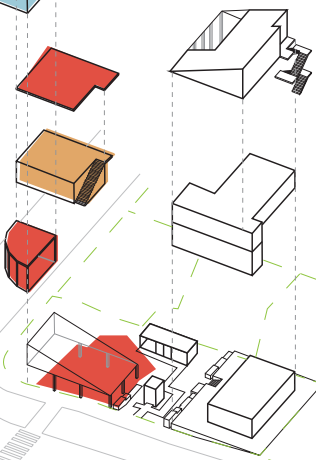

$3 P M$

$T_{6 P M}$

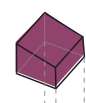
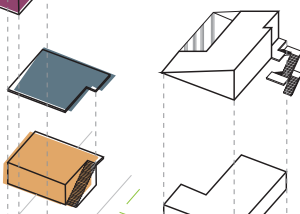

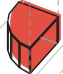

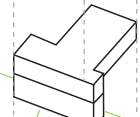

iㅏ)

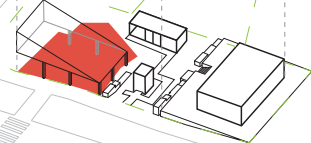

$6 P M$

$M-17 P_{M}$ =restaurant/cafe

$=$ commercial kitchen

=meeting space/community room

=events, such as festivals

$=$ market

$=$ outdoor movies 


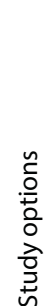
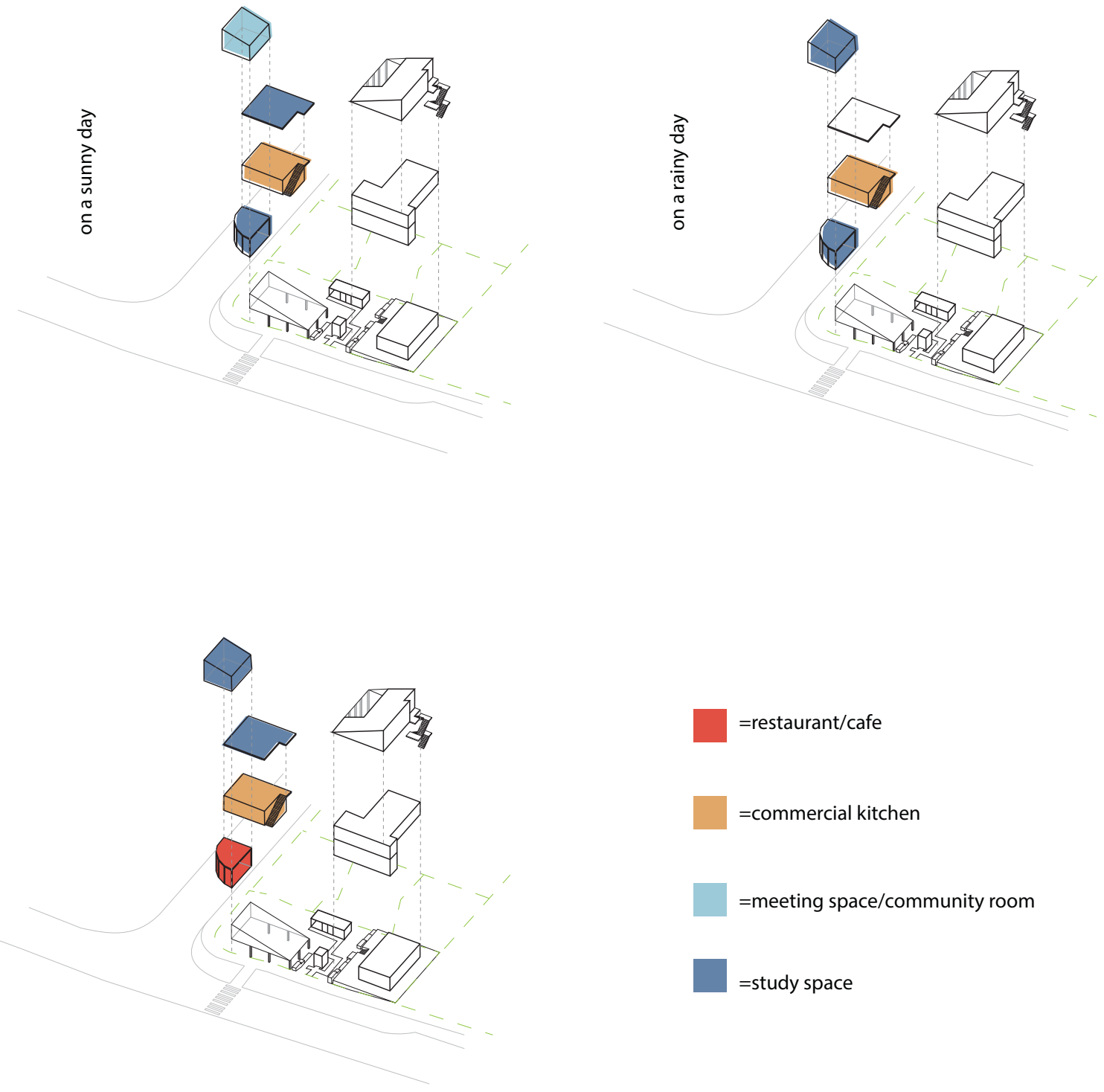

Figure 8.07 


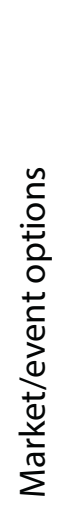

$\checkmark$

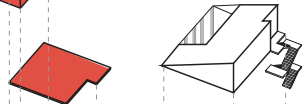

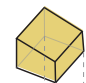

$n$
$\frac{1}{0}$
$\frac{0}{0}$
0
0
$\frac{0}{0}$
$\frac{1}{d}$
$\frac{1}{0}$
$\frac{1}{\vdots}$
$\frac{1}{2}$

$\rightarrow>0$
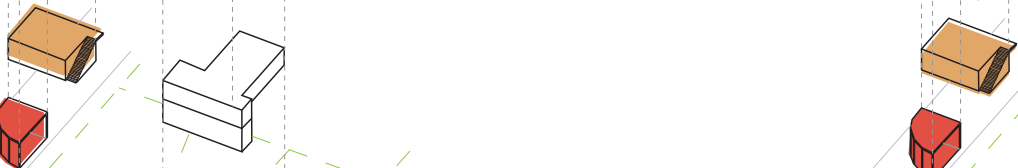

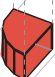
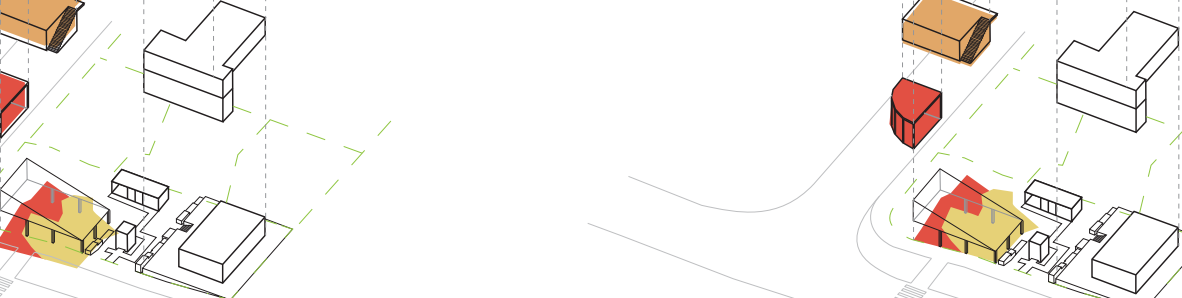

$->>$

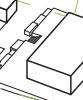

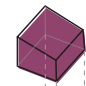
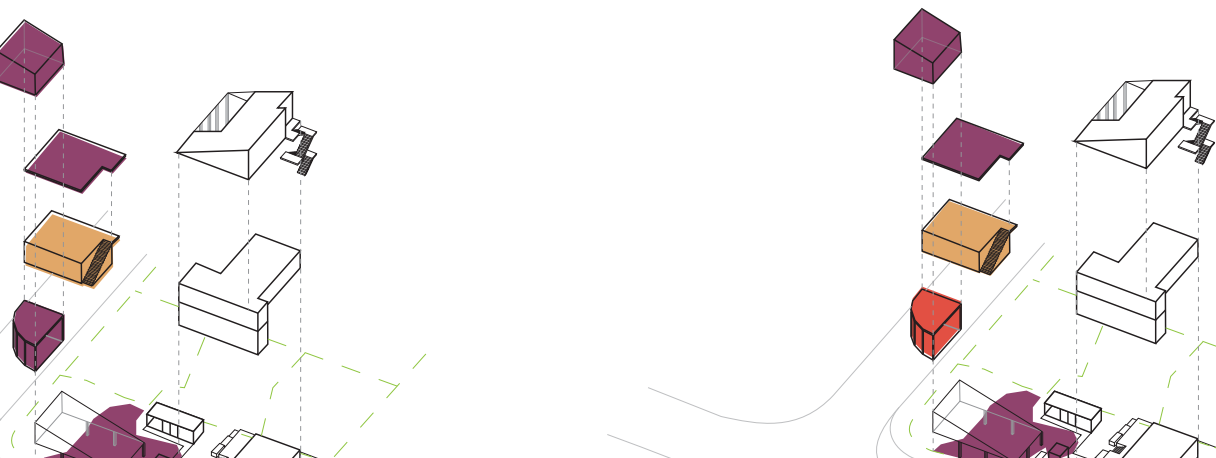

iv
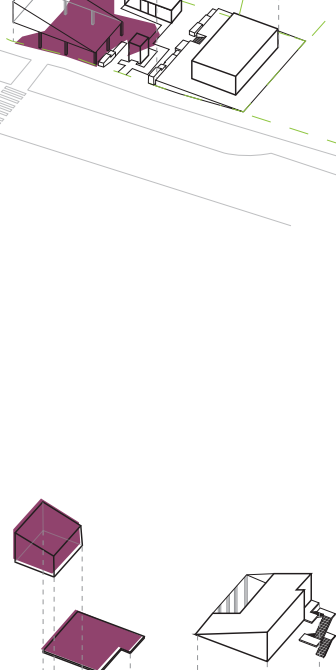

$=$ restaurant $/$ cafe
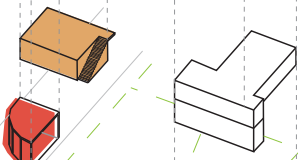

=commercial kitchen

=events, such as festivals
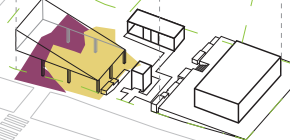


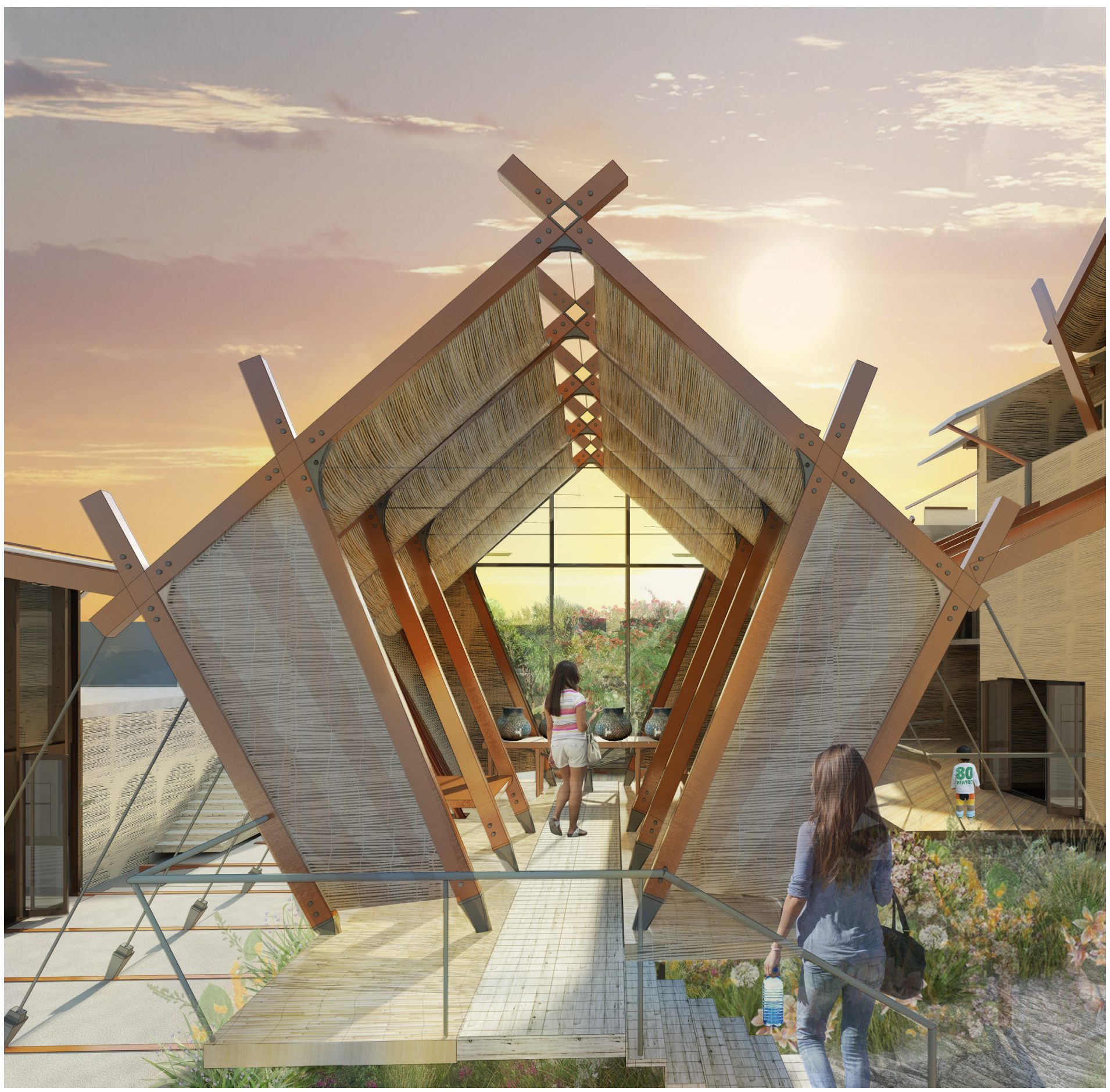

1. Figure 8.08 Ritual is important in Myanmar. The front door of a

dwelling faces east, to bring to luck-bringing morning sun. When leaving the

Well, standing at the top of the stairs, you would be facing east. This subtle connection is an act of integration, in which the space can influence action. 


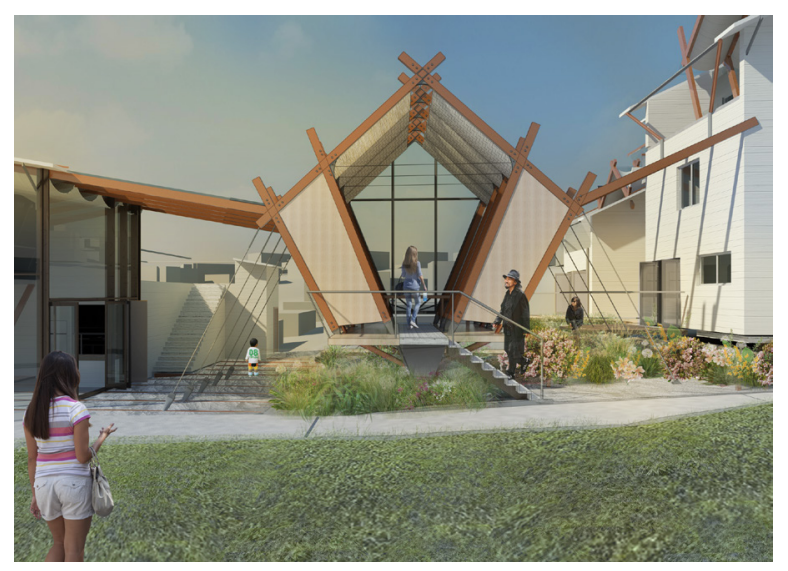

"Water is essential

for life, and bringing

access to

fresh water

in Porirua is

our gift to the

community.

Figure 8.09 The centrepiece of the Myanmar Well Centre is the Rainwater's Well which is an airy open building which can be accessed off Mungavin Avenue, near Mungavin hall

\section{Myanmar Well Centre}

On Mungavin Avenue, next to the Mungavin hall, Wellington's Myanmar community has opened a community centre which features a rainwater collecting tank. This will provide locals with a free freshwater supply, much like the free artesian water supply in Petone.

"Water is essential for life, and bringing access to fresh water in Porirua is our gift to the community. Fresh water is a shared resource in Myanmar and our Rainwater Well center reflects this. You can walk up into the Rainwater Well straight from the street. As a building which represents connection, it is vaulted up above a lush rainwater garden and fed from the water which comes down from the surrounding buildings. This building is open and a spiritual place, with a hanging bamboo ceiling which creates an atmosphere of reflection." says Sandi Hla Shein, the chairperson of the NZ Myanmar Ethnics Council (NZMEC)

\section{The Rainwater tank is the} centerpiece of NZMEC's vision for the center, which includes a commercial kitchen, cafe, community meeting rooms, and three dwellings including accommodation for an onsite manager-caretaker. 


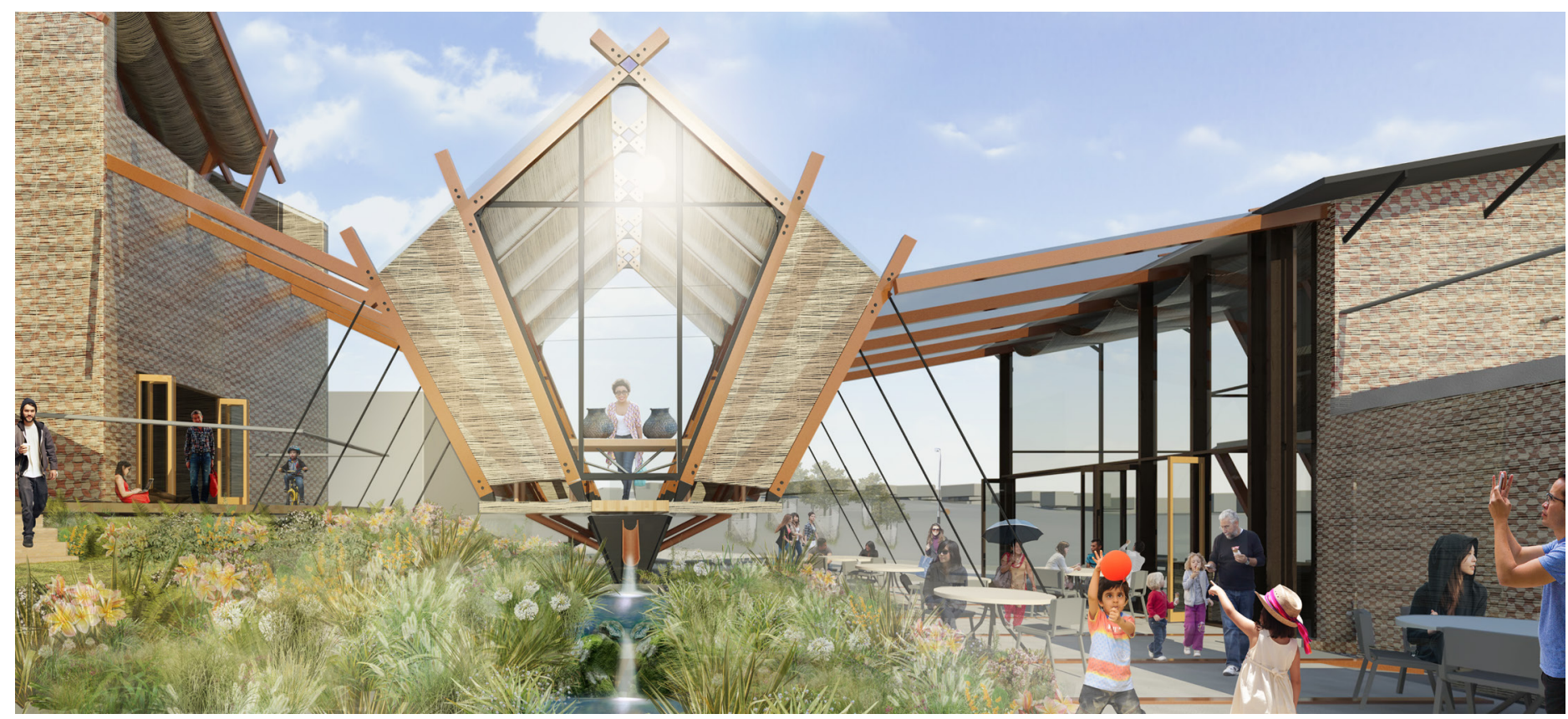

Figure 8.10 The gently swooping roofs of the dwellings and the

3. commercial connect in a meeting point which contains a rainwater well. This moment of connection is both made vibrant, with the movement of the diverse wider public as they collect fresh water, and acts as a gentle rythmic mediator as the flow of water trickles into the raingarden. 

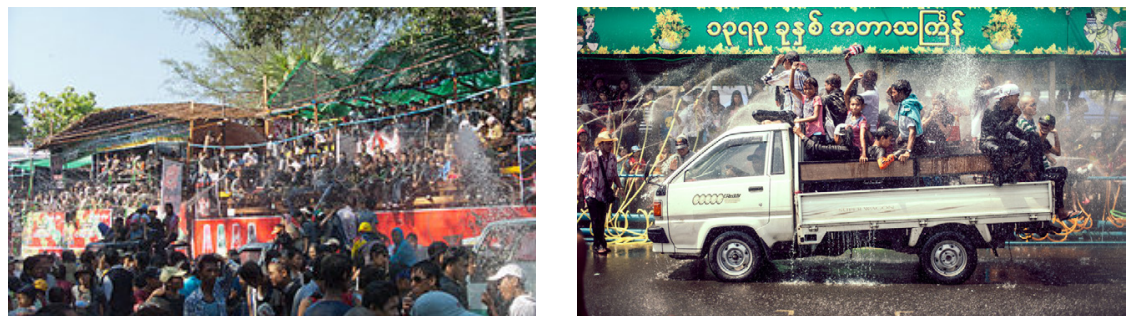

Figure 8.11 Images of Thinyan in Myanmar, photos by Yoav David and Thels Kofoed Hjorth

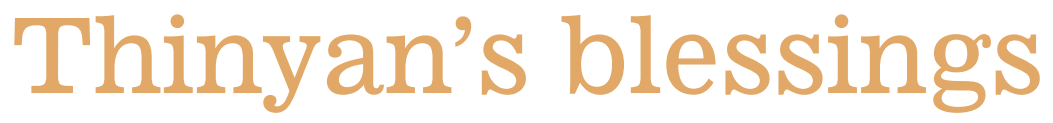

\section{"The festival was a cool experience, the Myanmar people are a lively bunch, I felt really welcome and I will come back next year"}

The gods shone on Porirua's Rainwaters' Well Centre at the weekend when the Myanmar Community celebrated its 10th New Year Water festival in Wellington. Traditionally held in the hot month of April in Myanmar, the festival involves dancing, feasting and dowsing friends and neighbours with water as a cleansing ritual, and to offer blessing and good wishes for the New Year.

"I was on my way to get Friday night fish-and-chips when I heard music from the new building next to the town hall. I walked through people sitting outside on tables, and I was offered food from a long table underneath a hanging bamboo ceiling. As I took my food back outside, I walked upstairs onto a large deck and watched a dance performance. A man holding a branch with yellow flowers told me that this was a New Year's festival in Myanmar, which used water as a cleansing ritual. He then sprinkled me with the branch to wish me luck.

"There were kids running everywhere, from across the decks of the houses, to around the rainwater garden and up on the deck of the main stage. One little child even took part in a dance! The festival was a cool experience, the Myanmar people are a lively bunch, I felt really welcome and I will come back next year," says Jim Taylor, a local resident. 


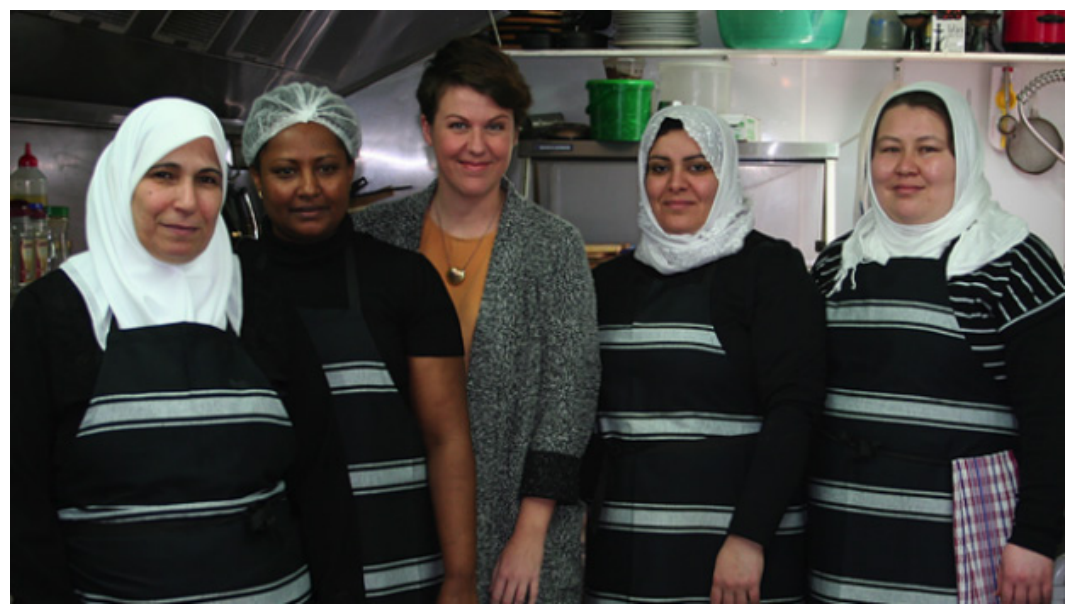

Figure 8.12 The ladies from Pomegranate kitchen, photo from Pomegranate Kitchen

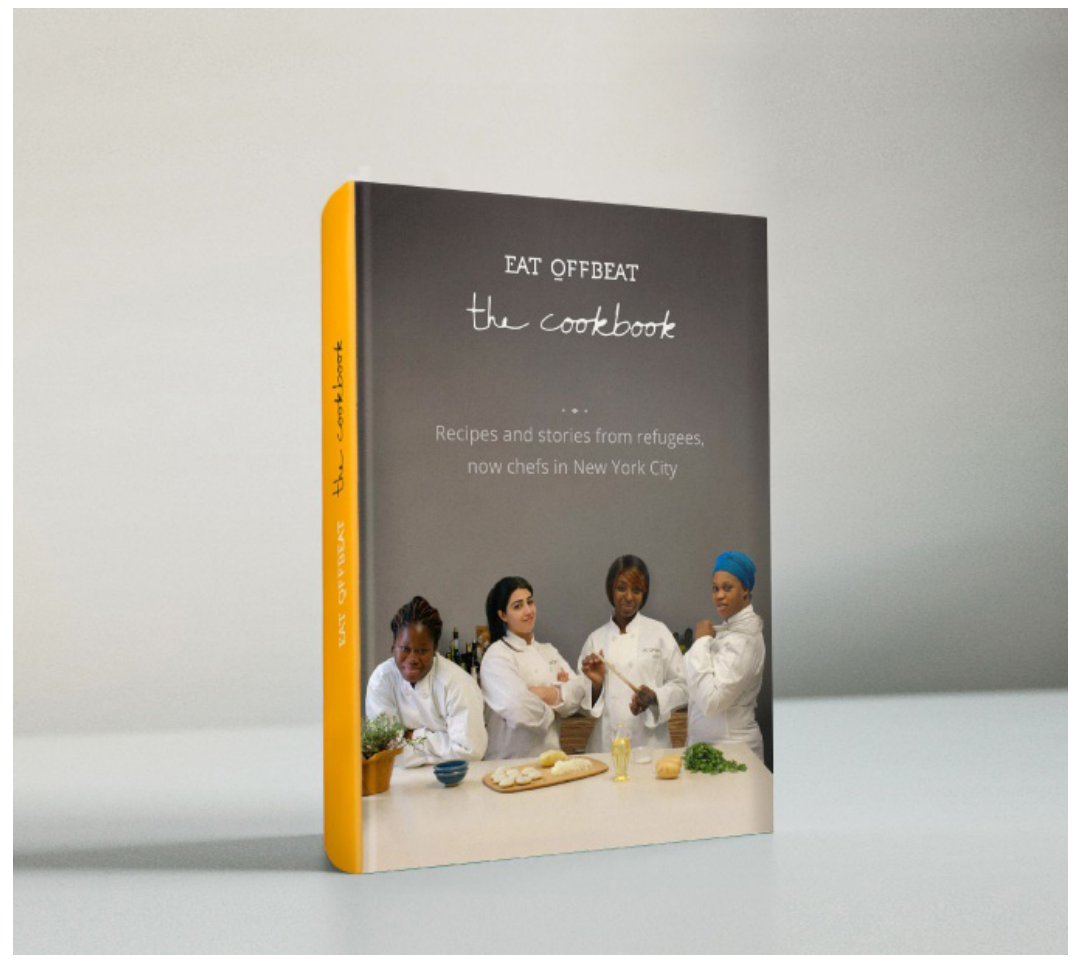

Figure 8.13 Eat offbeat is a real cookbook from a refugee kitchen in New York 


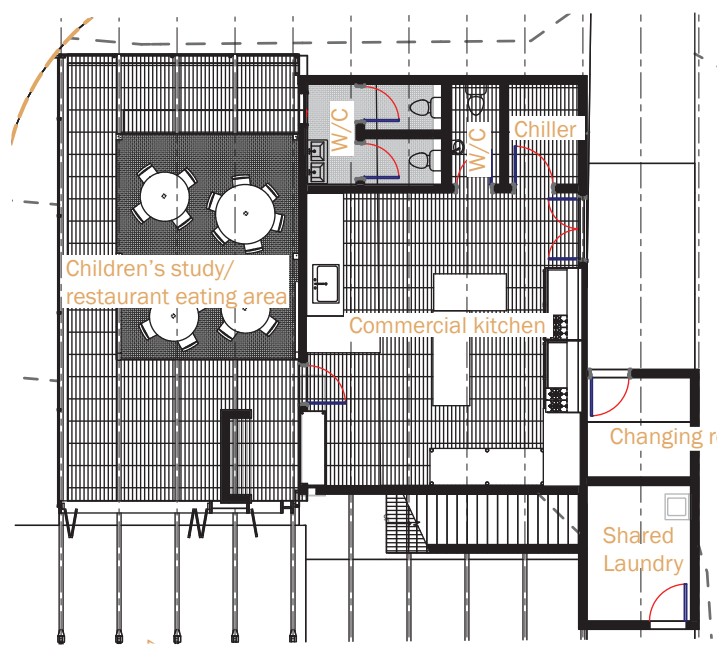
"[Refugees]
, skillsets are
underutilised
and if given
the chance,
they can be
nurtured into
entrepreneurs."
- Rebecca
Stewart from
Pomegranate
kitchen (Strang,
2017)

Figure 8.14

a plan of the commercial kitchen

\section{Pomegranate Expands}

Wellington's Pomegranate kitchen is expanding into Porirua and Kāpiti. The catering and lunch delivery social enterprise, which is run by refugees, has been so successful since it began two years ago that they needed additional commercial kitchen space. They will be renting facilities at Porirua's Rainwater Well Centre.

"The first time I walked into our new kitchen, we came in through the back door and I saw how spacious it was. There was room for separate food stations, so I could bake baklava and Maria could make mohinga at the same time. On the other side of the room the wall opened into a restaurant space. I walked through and saw a group of children quietly studying underneath a low ceiling. I heard the murmur of voices, and I looked up to see the Myanmar Ethnics Council having its monthly meeting." Says Shayma Maloof, a former refugee and the head chef of Pomegranate kitchen. 

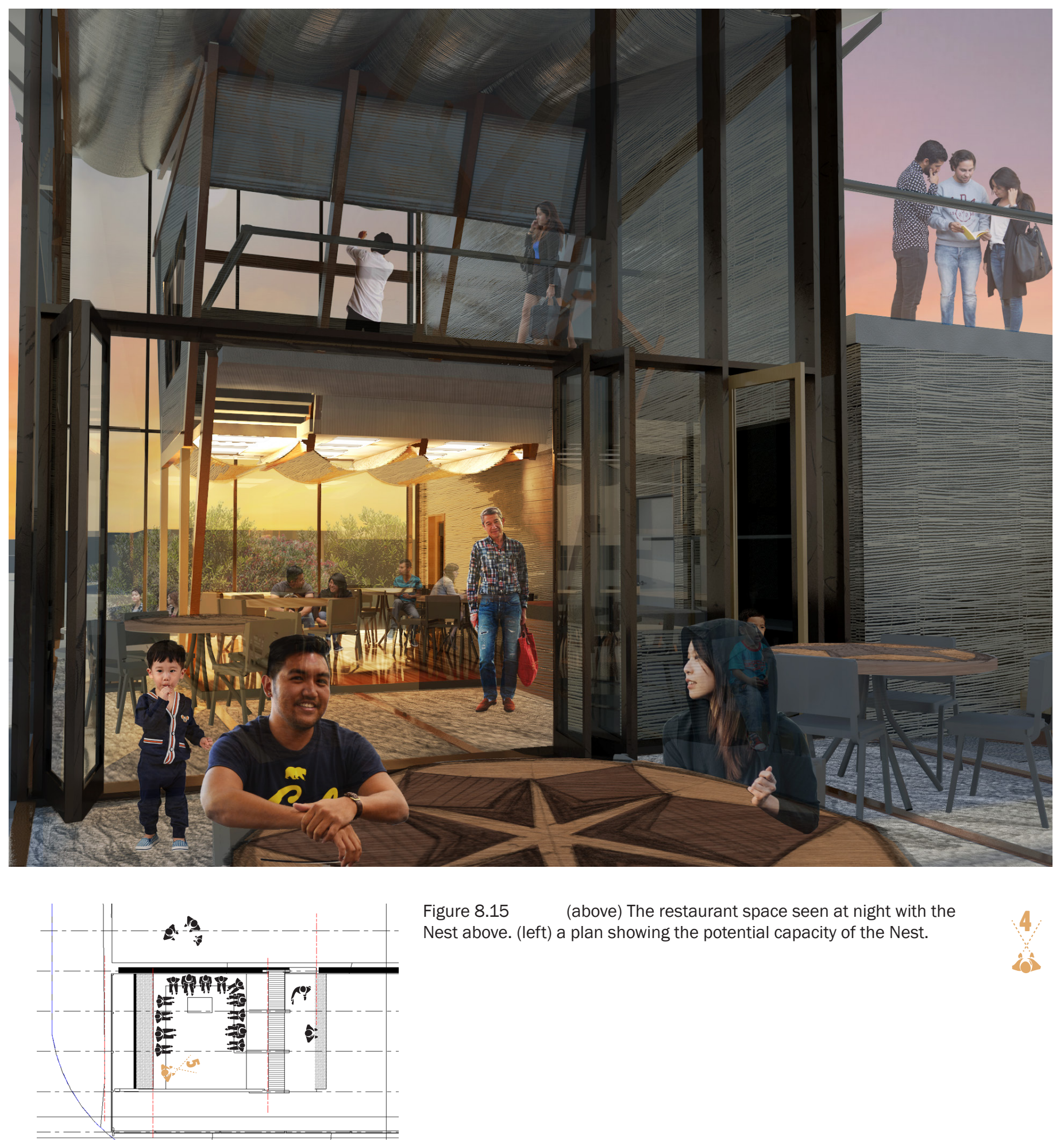

Figure 8.15 (above) The restaurant space seen at night with the Nest above. (left) a plan showing the potential capacity of the Nest. 


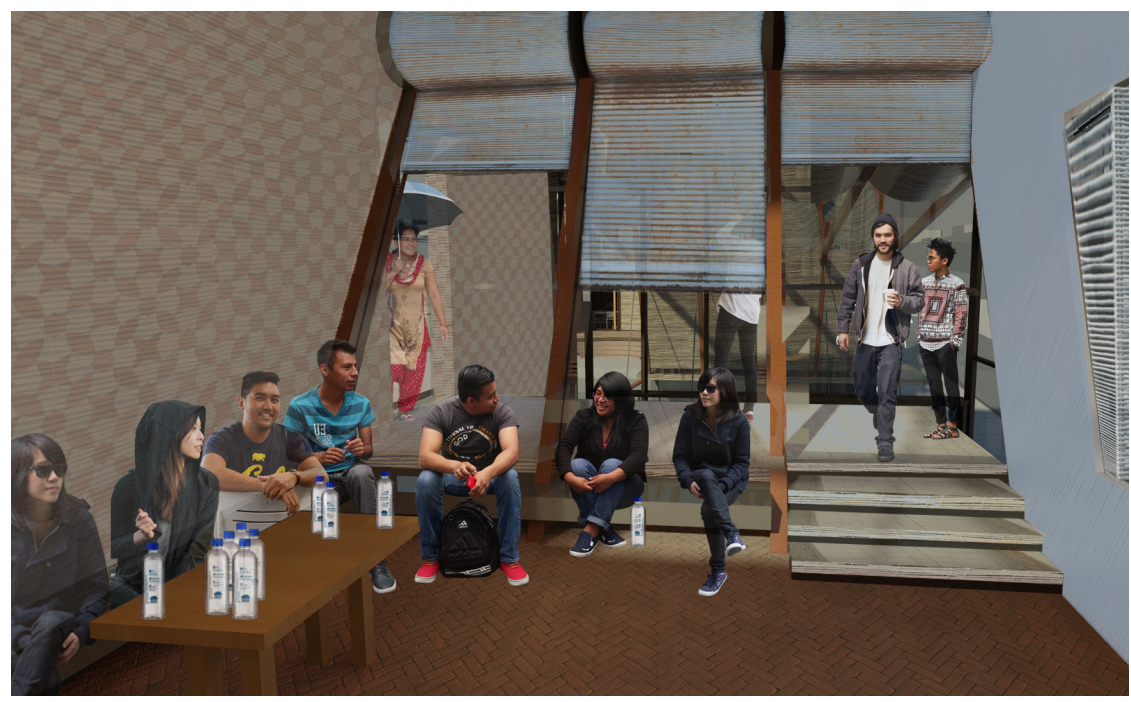

Figure 8.16 The interior of the Nest

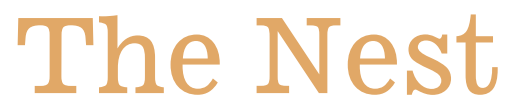

A new community room, run by the New Zealand Myanmar Ethnics Council Inc (NZMEC) perches above the flexible space below. Today this flexible space held a children's study station which later transformed into a restaurant. The NZMEC is a community group which supports members of the community and advocates for New Zealand Myanmar Ethnics.

The meeting room, which is known as the Nest, holds up to 15 people and is accessed across an exterior north-facing deck. The Nest has folding windows and a wall of rolling doors, so that it can be open to the

space below during a community event, or completely closed off for a quiet meeting.

"As a member of the NZMEC, I enjoy walking through the Saturday market to scout out fresh veges on the way to our monthly meeting. We usually leave 'the Nest' open because we like to feel a part of the events in the space. However, sometimes we have private meetings and then we close everything up. Aung Thanda remarked to me how they know something important is happening when we do this!" says Aye Htet Mya, who is local and walks to the meetings from her home. 


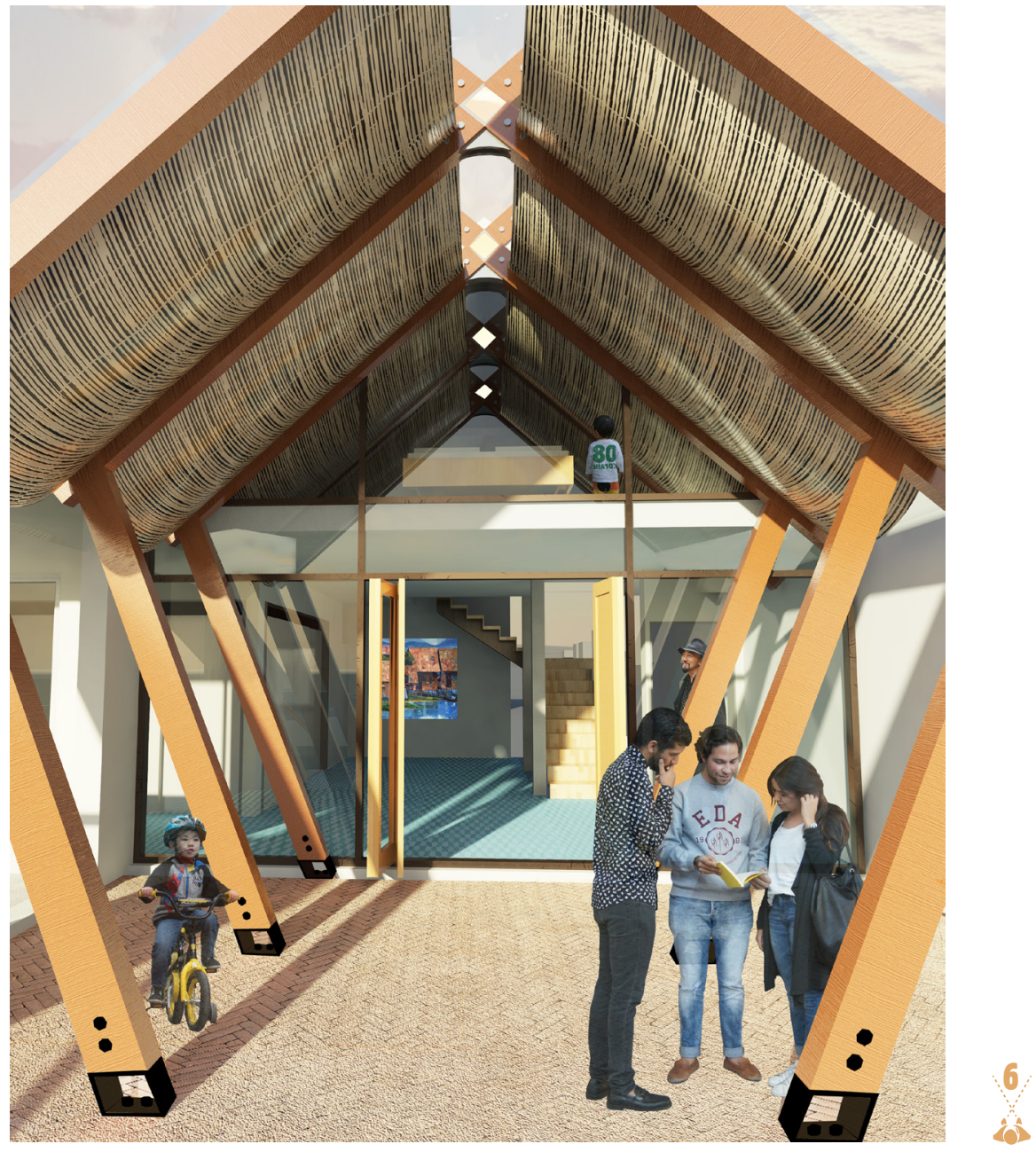

Figure 8.17 Looking from the top deck into the two-bedroomed dwelling 

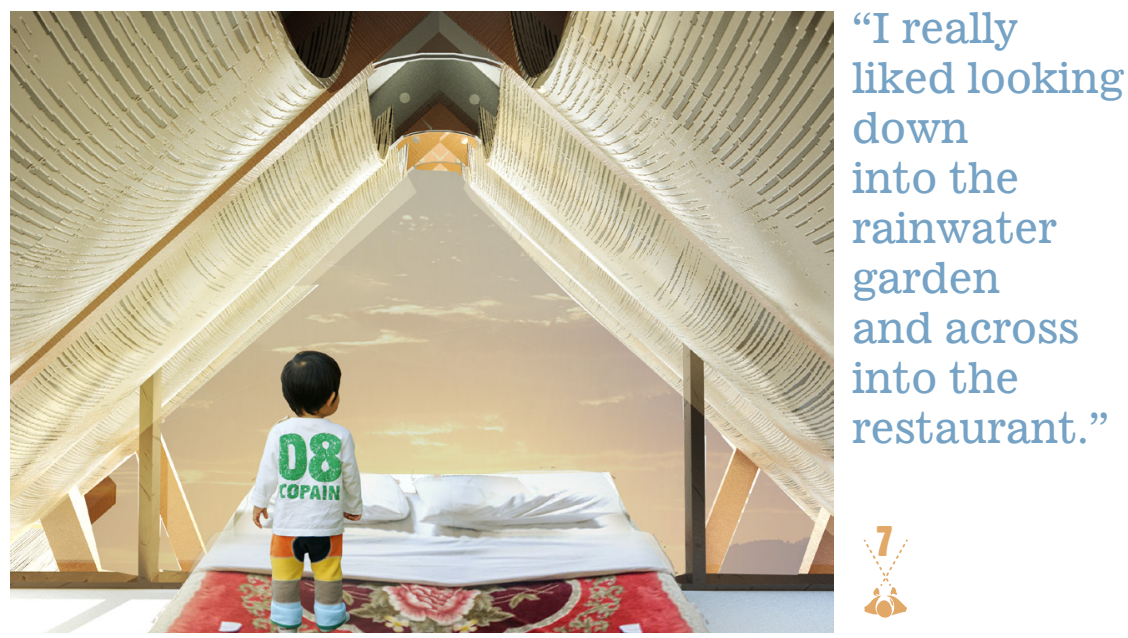

Figure 8.18

As another day ends, the evening light filters through the hanging bamboo ceiling into this loft space.

\section{A new home}

The New Zealand Myanmar Ethnics Council (NZMEC) are looking for new residents to inhabit their new apartment complex. There are three dwellings in this building, designed for a diverse set of demographics. This includes: a three-bedroom family home, a downstairs granny flat and the two-bedroomed upstairs apartment. This is to create a vibrant space, where a variety of people will interact.

The available apartment is on the top floor and it has two-bedrooms in a loft space.
"I came to the open day to check it out. I walked past the Rainwater's Well Center, and down a private path just off the street. Once I got up to the apartment I was amazed - it looks right out onto a deck which looks over the whole space. You can see everything, I really liked looking down into the rainwater garden and across into the restaurant.

The loft space was great too, I liked how the bedrooms where so private while still having a view", says Jane Fritzl who is a curious local. 


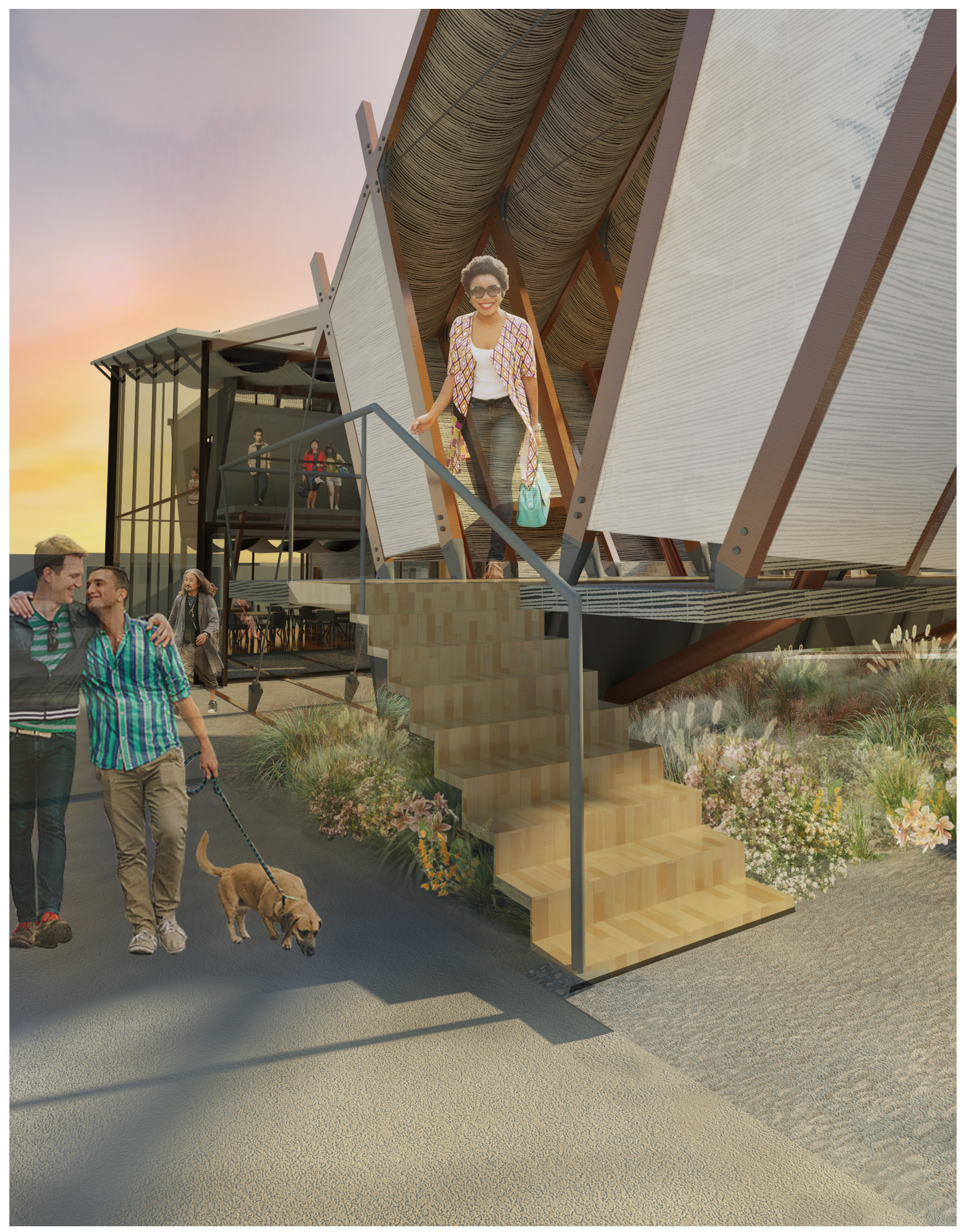




\section{Journey through the Rainwater's Well}

The Rainwater Well connects and mediates between events, functions and people. It contrasts the cool running of water with the fiery heat of a busy kitchen. The natural movements of the water and plants in the raingarden set a backdrop to the busy social space of the kitchen, 'the Nest' and vice versa.

The Well is not just a moment of connection, it is also a destination -a place to encourage intercultural contact, but also with a specific meaning for a community. This section goes on a journey through the Rainwater Well to experience the moments within this vital device.

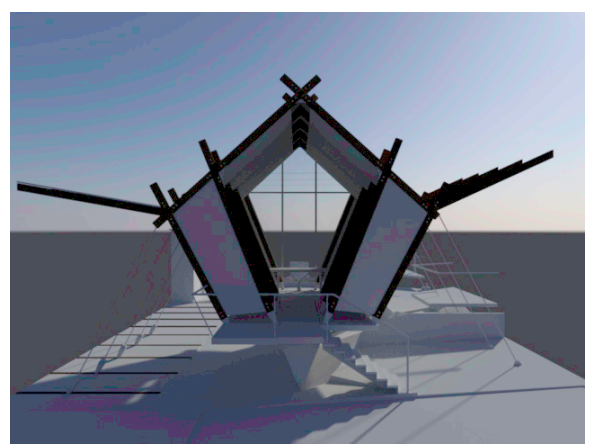




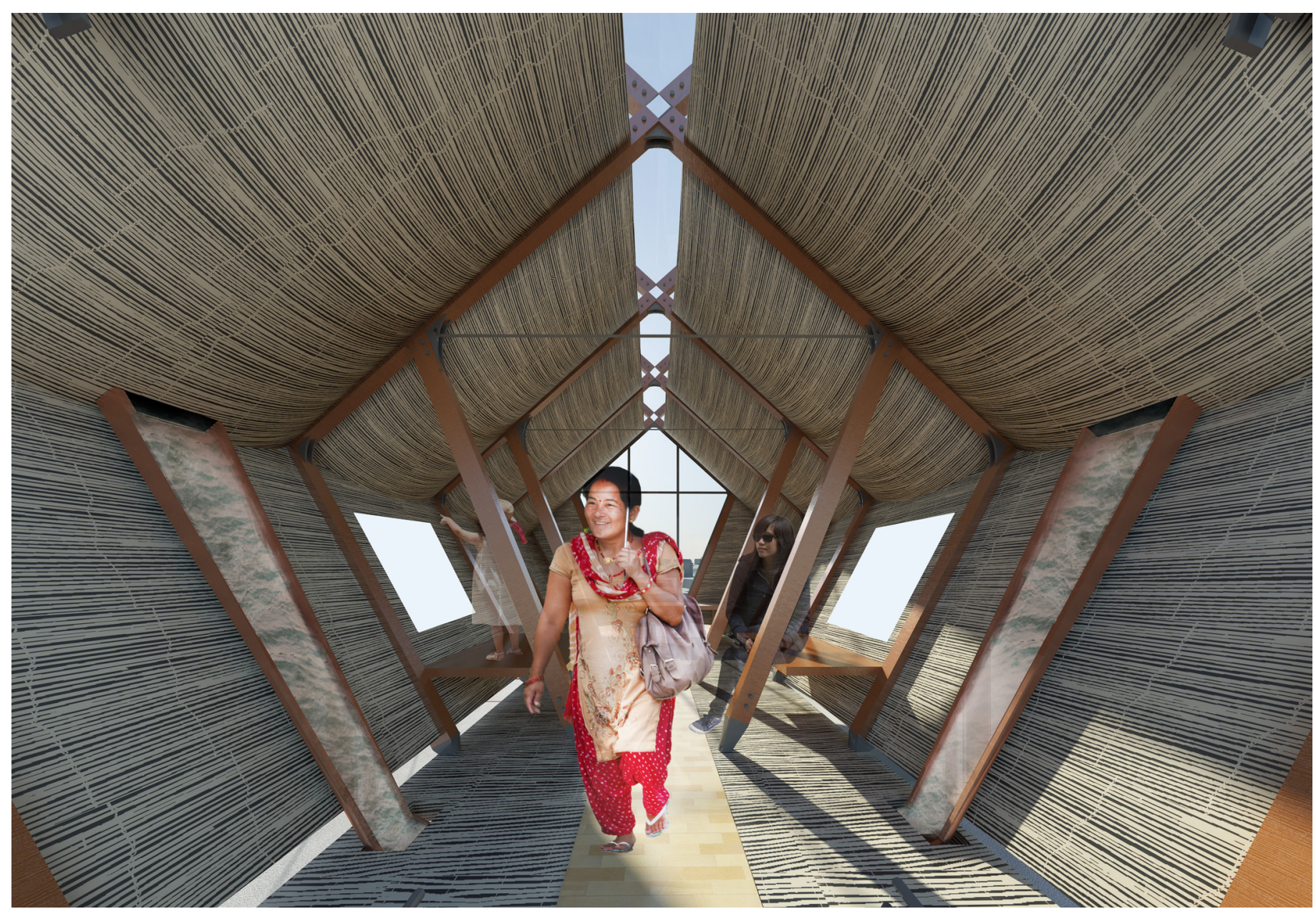

9

\&

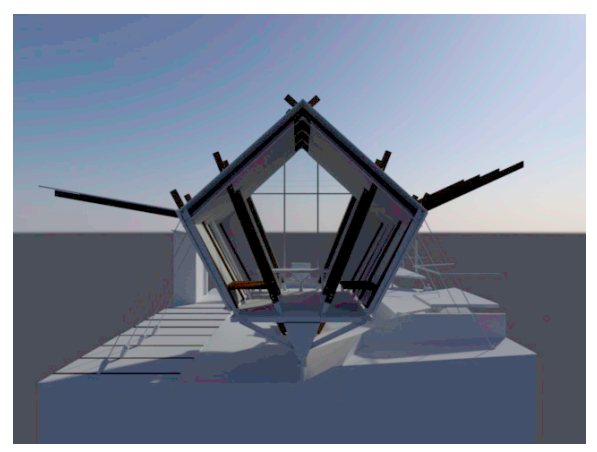

Figure 8.19

Water flows from each

building into the tank underneath the pathway.

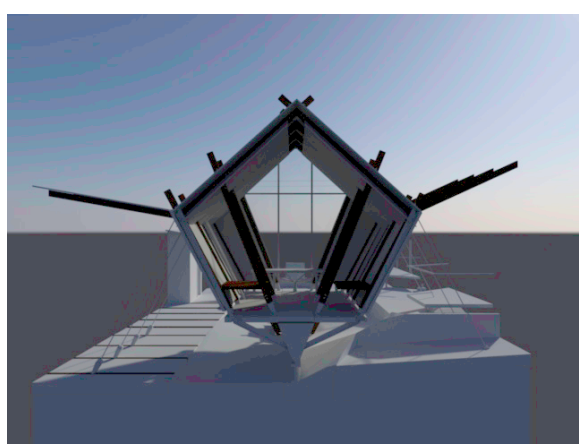

Figure 8.20 seating is placed on either side to provide a reflective place to sit, with small windows above to provide a glimpse into both adjacent spaces 


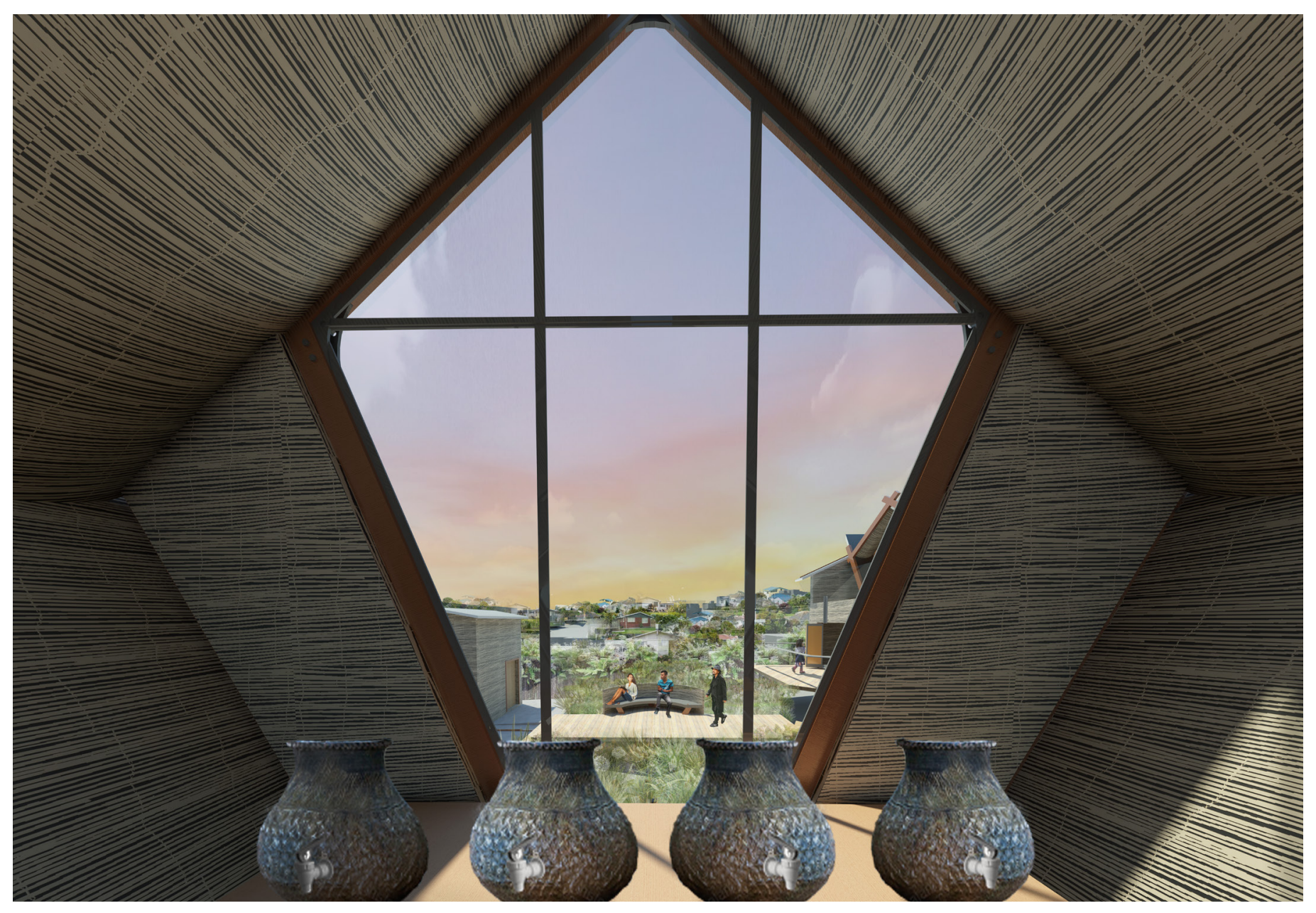

10

s

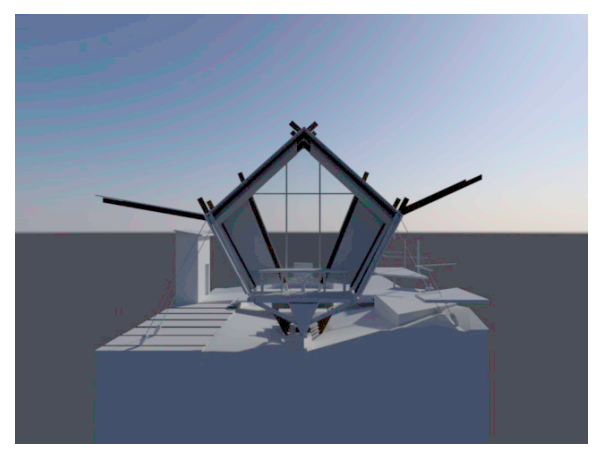

Figure 8.21 From the water jugs, the view overlooks the raingarden 


\section{Water's journey}

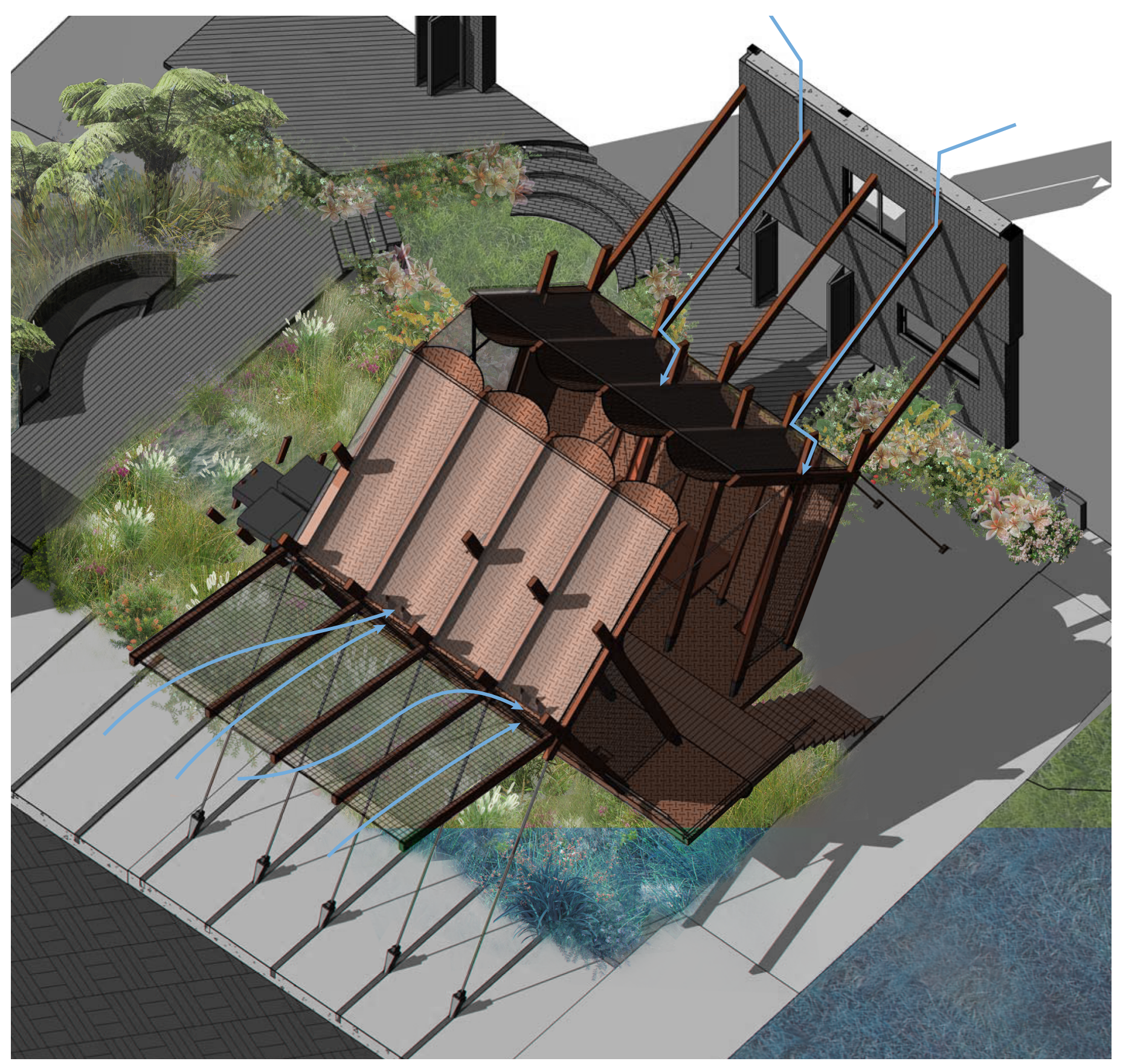

Figure 8.22

Water runs down from each roof and enters the downpipes. 


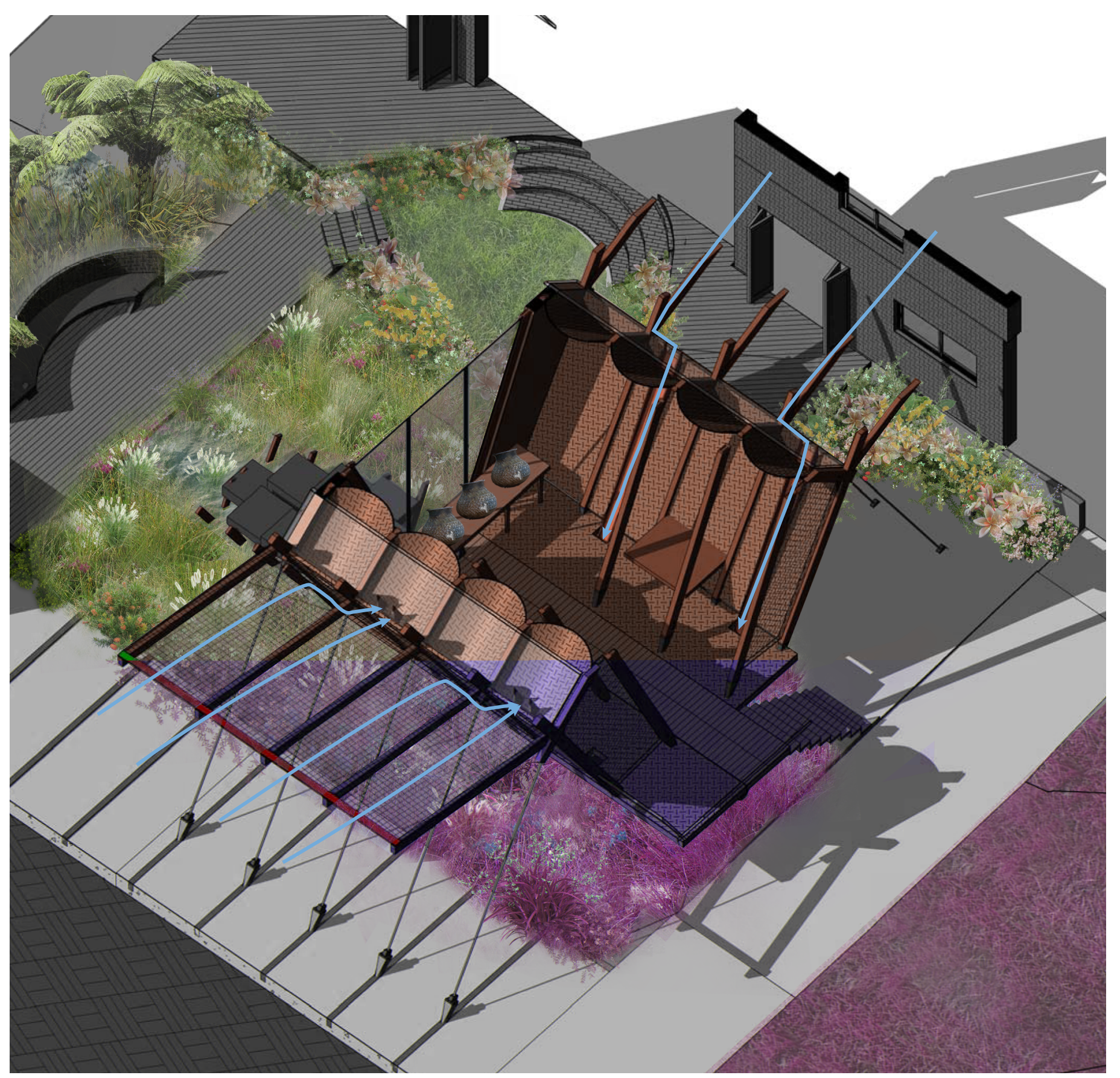

Figure 8.23

The downpipes run down on the inside of the walls 


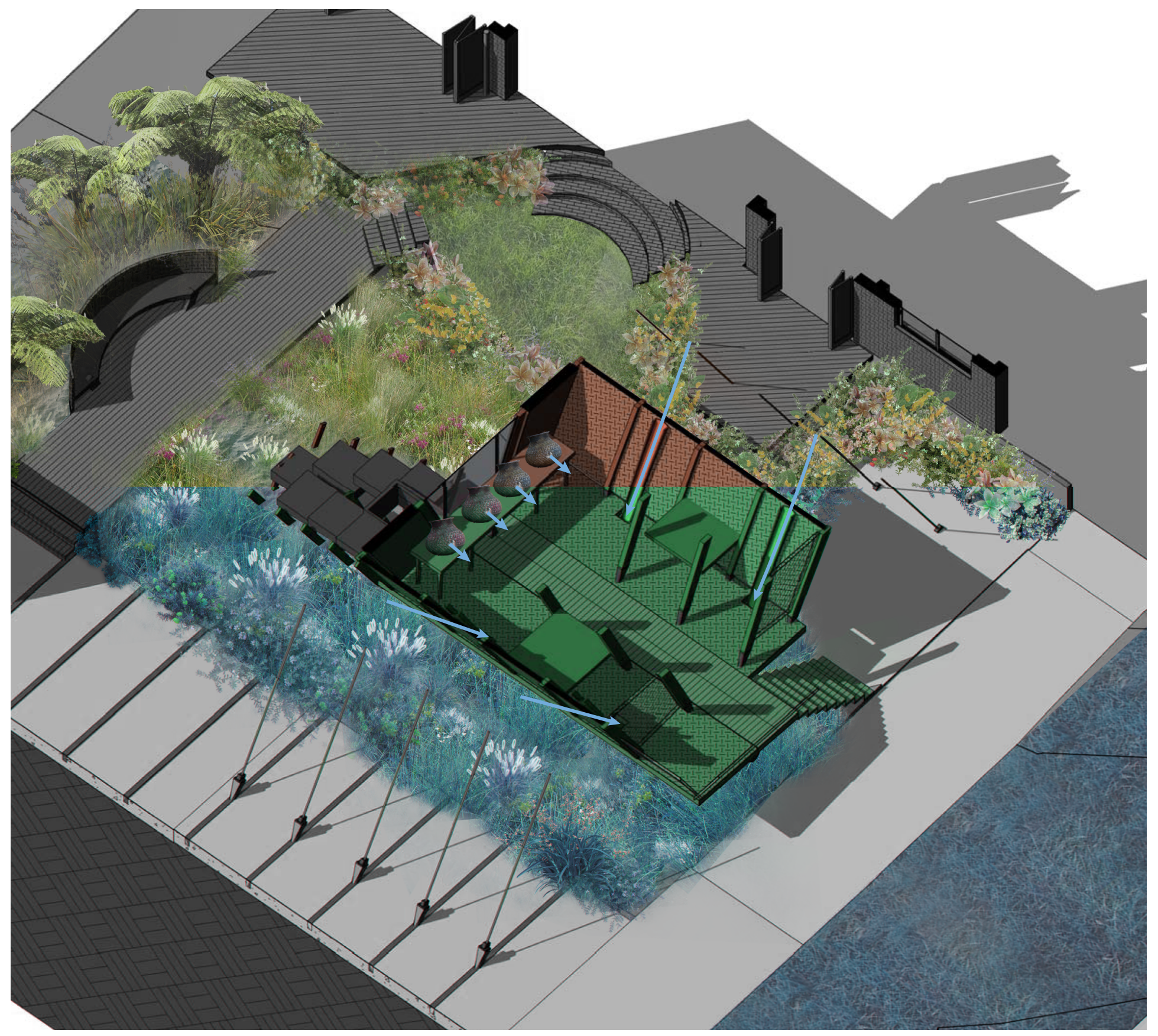

Figure 8.24

Fresh water can be collected through the ceramic jugs 


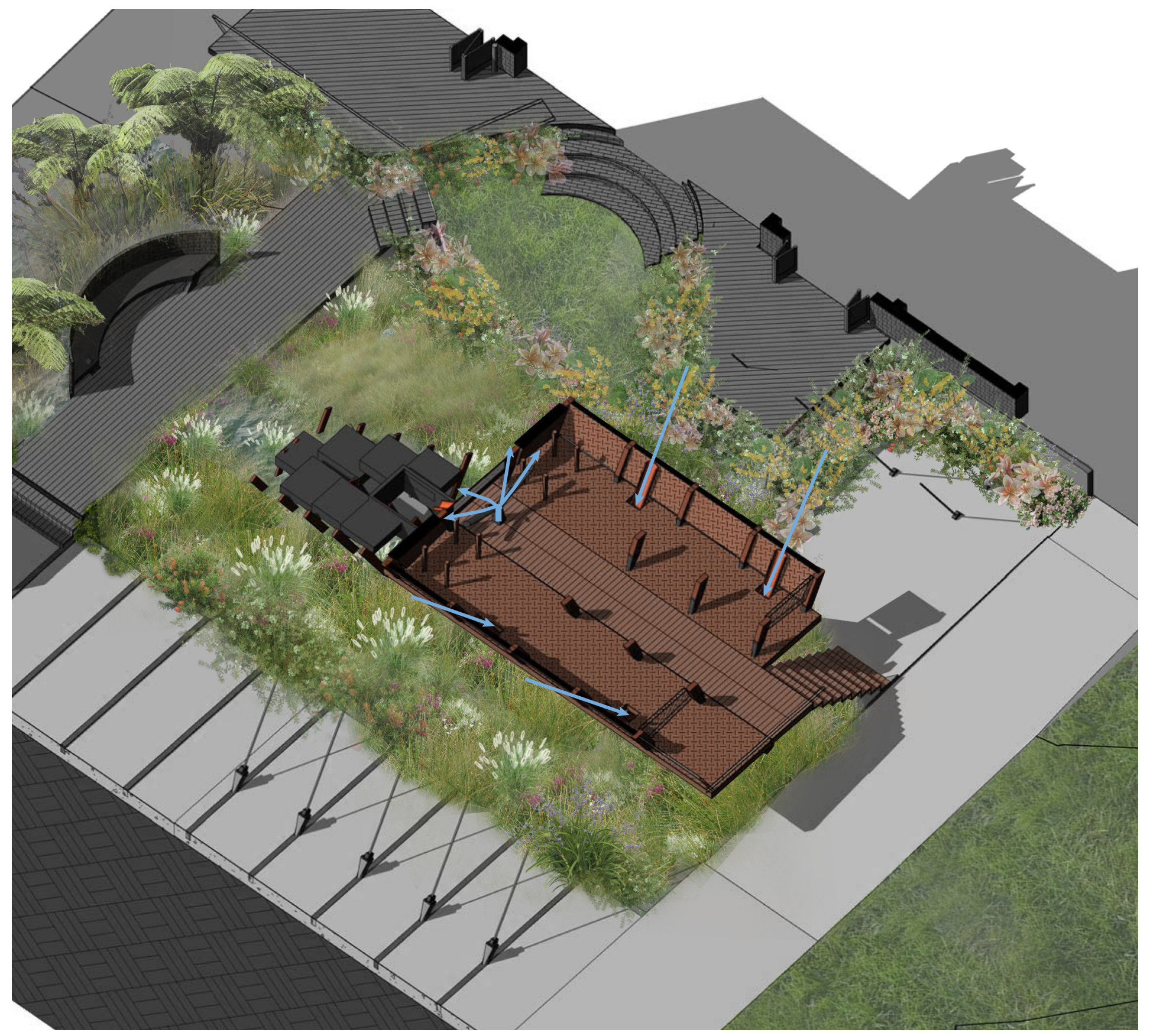

Figure 8.25 floor.

The water falls into the rainwater tank beneath the permeable 


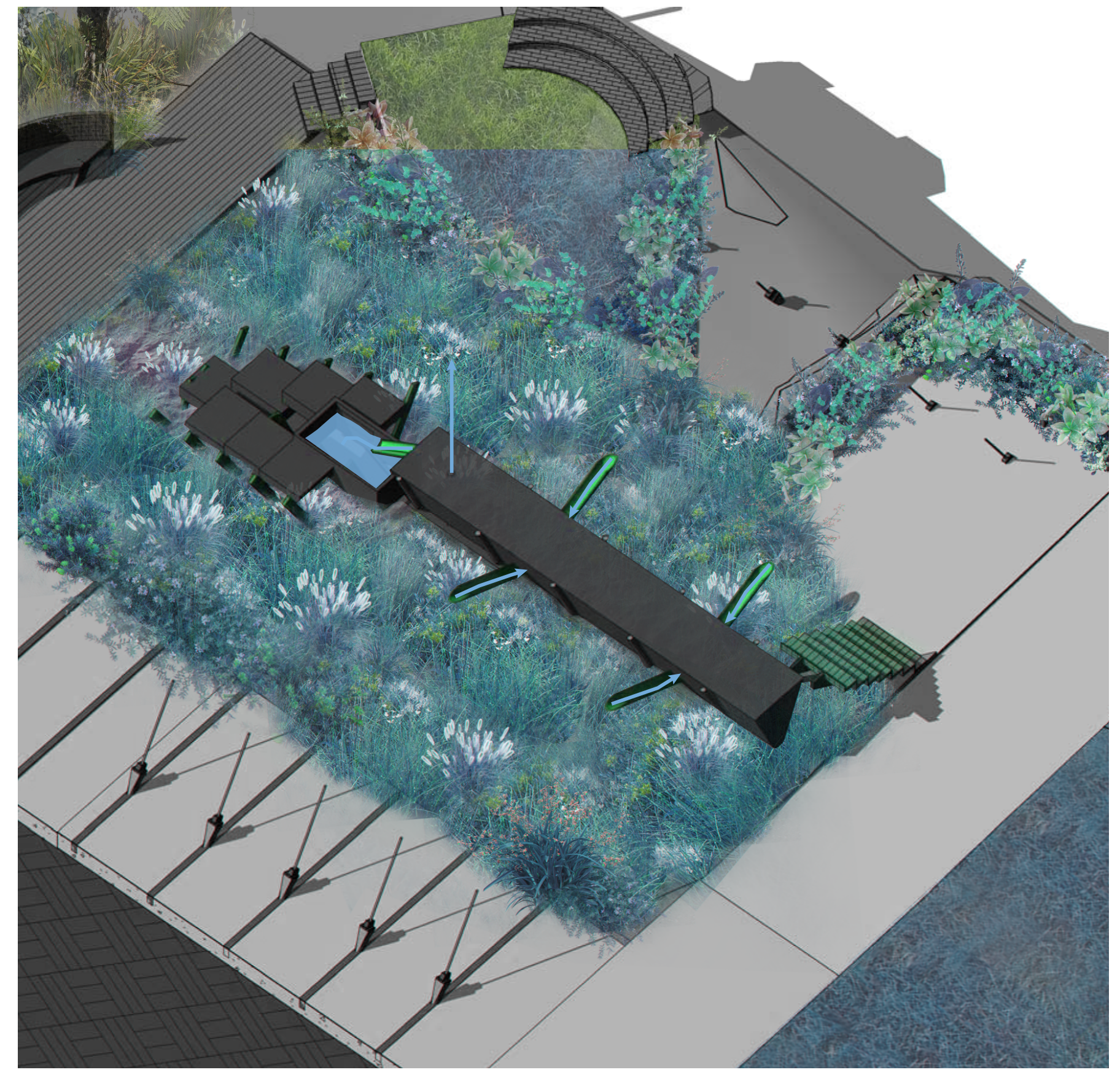

Figure 8.26 The point the water enters and exits the rainwater tank. 


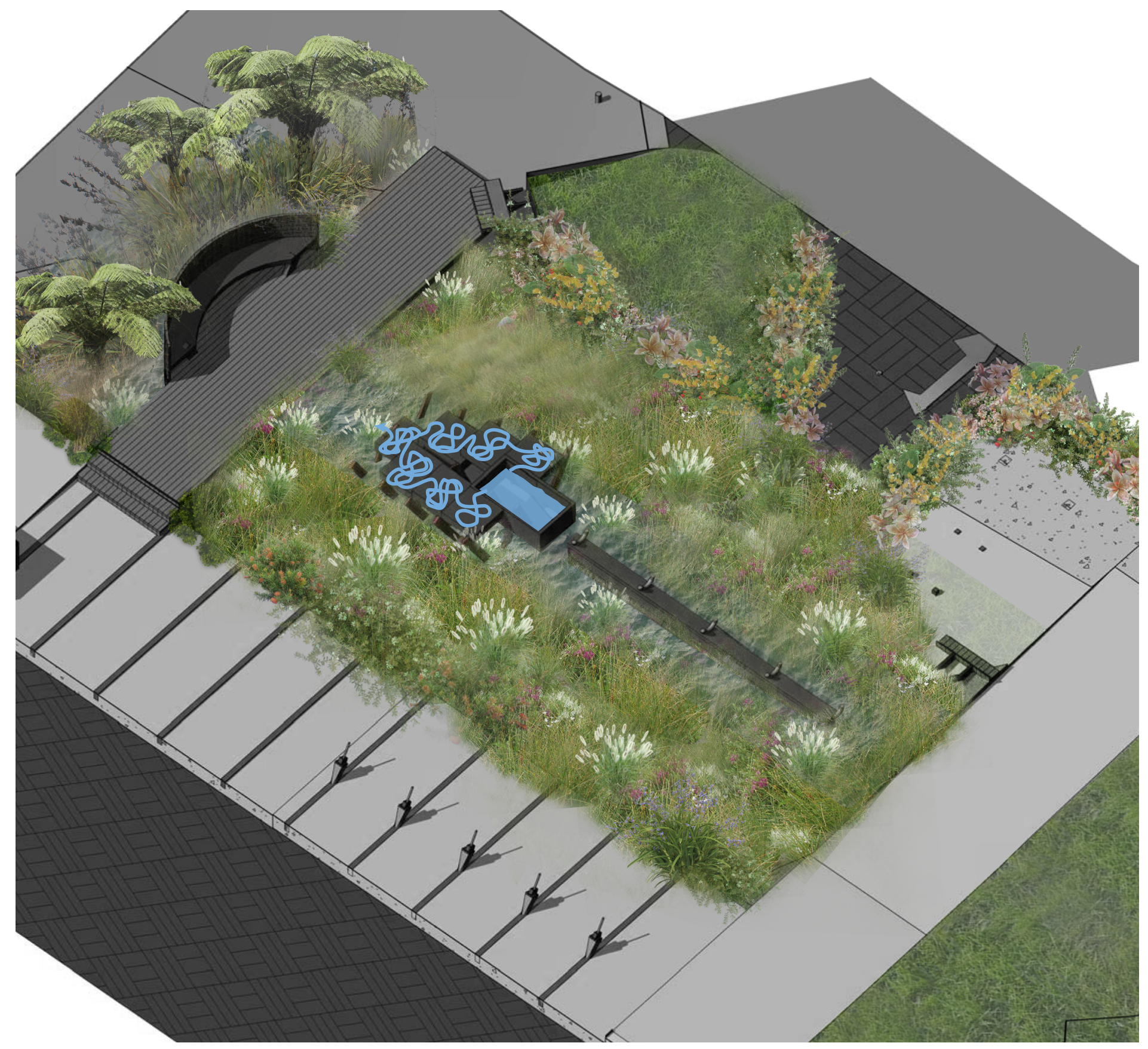

8.27 The overflow water rests in a small pond, then trickles down into the raingarden. 

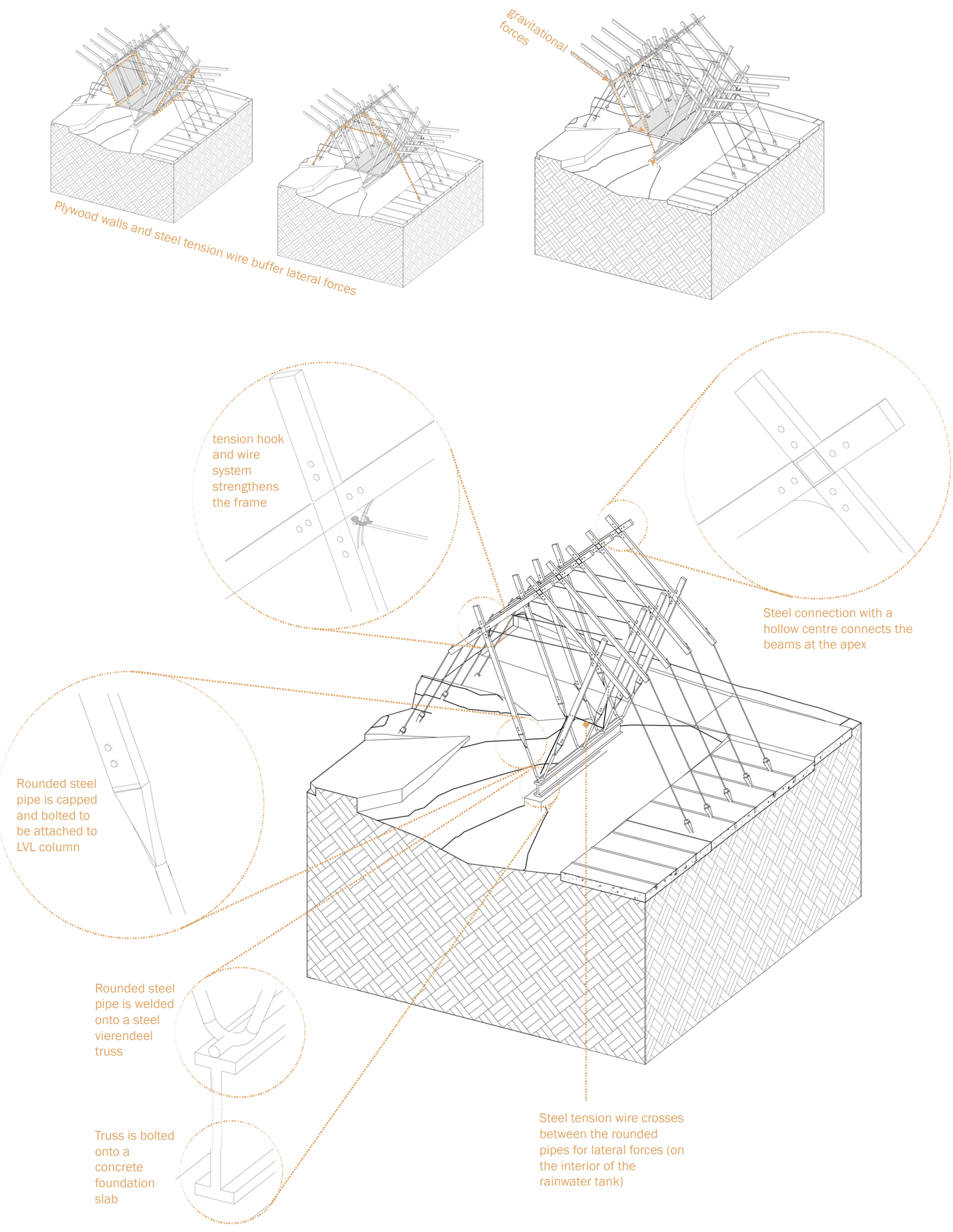
Structure and Construction

The Rainwater Well is a small light structure, made of wood and steel, it does not accomodate large amounts of people. This means that the building itself could 'float' suspended between the two roofs.

Figure 8.28 Consultation with Prof. Regan Potangaroa, a Professor of Architectural Science at Victoria University informed the strcuture of the Rainwater Well. Information gathered is outlined in this diagram. 


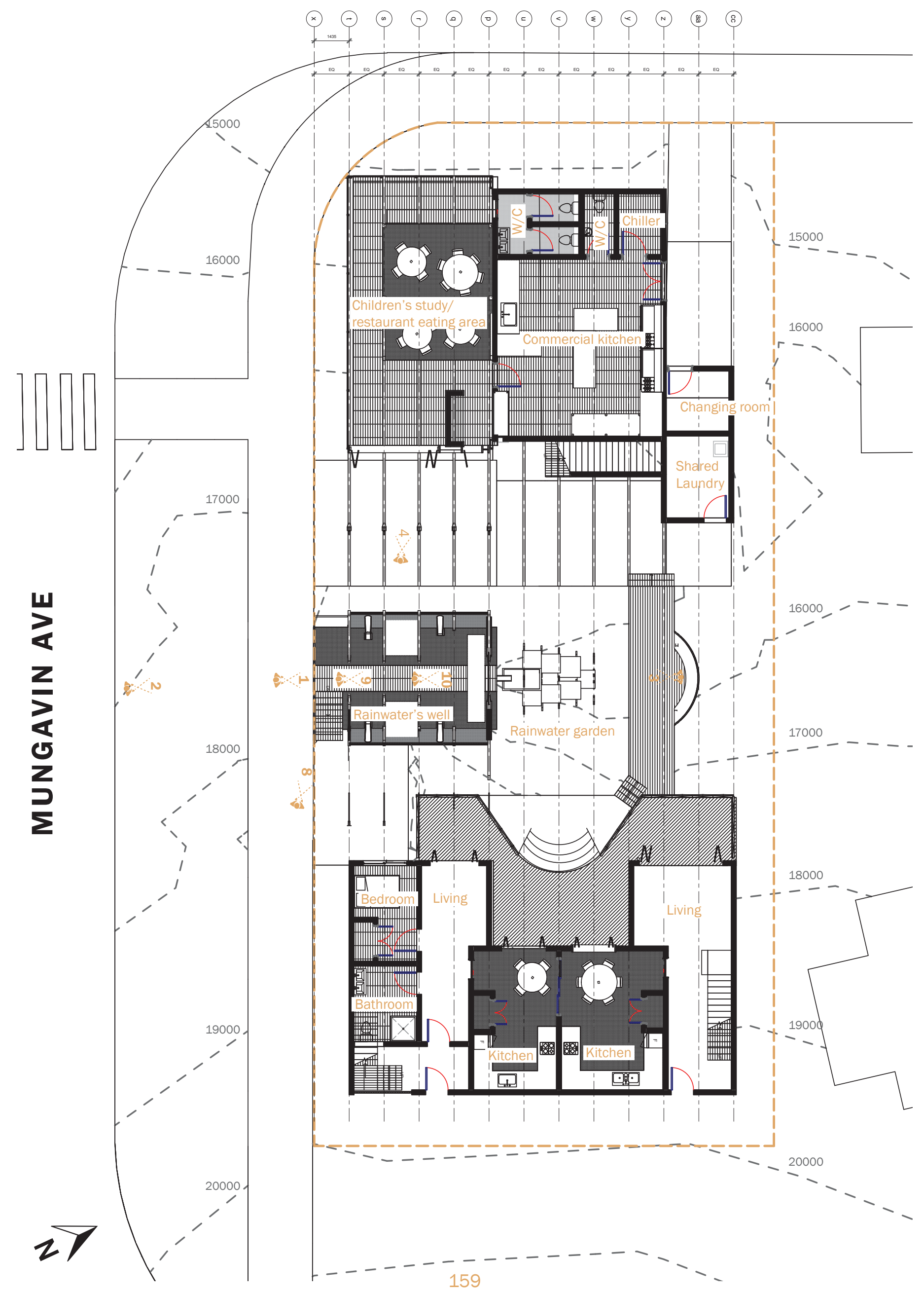


MCKILLOP ST

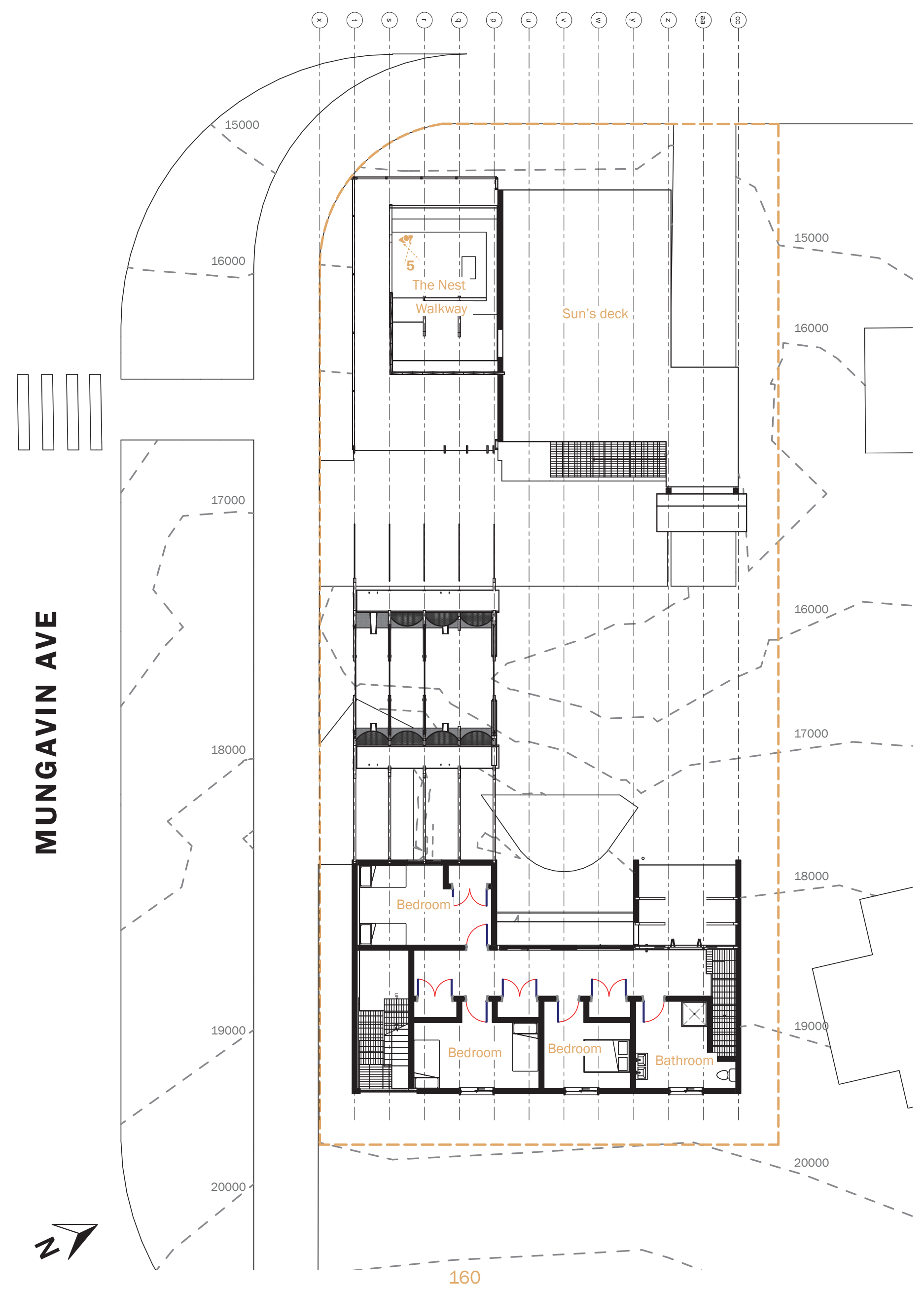


MCKILLOP ST

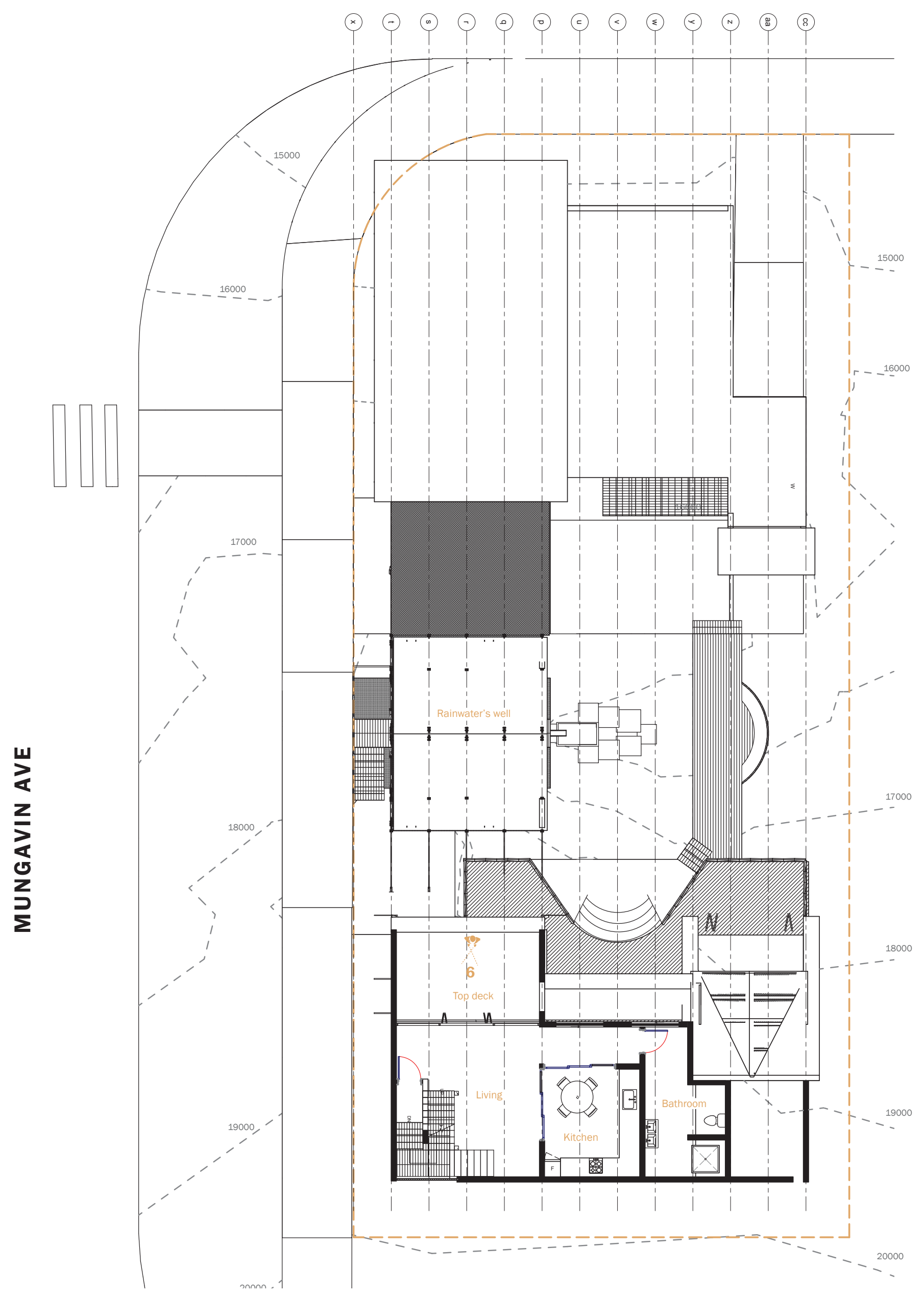


MCKILLOP ST

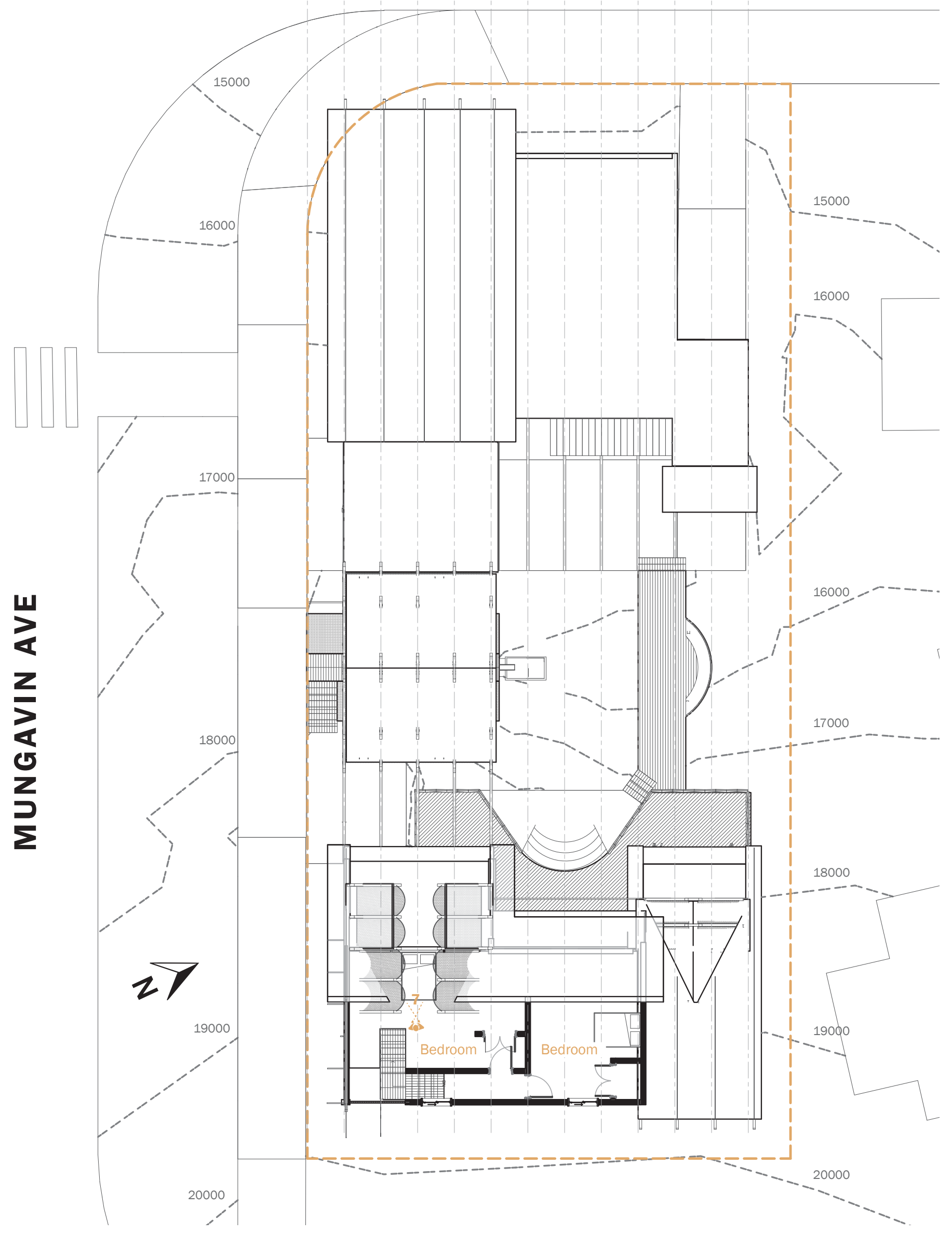




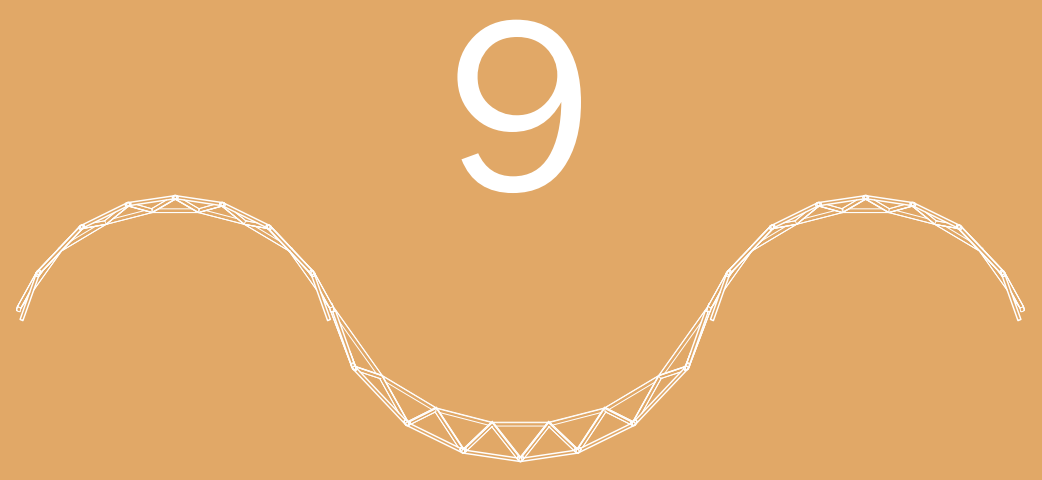




\section{Final Critical Reflection and Conclusion}

The reflection section will begin a critical reflection of the overall by covering the limitations of the thesis.

project and then will move into 

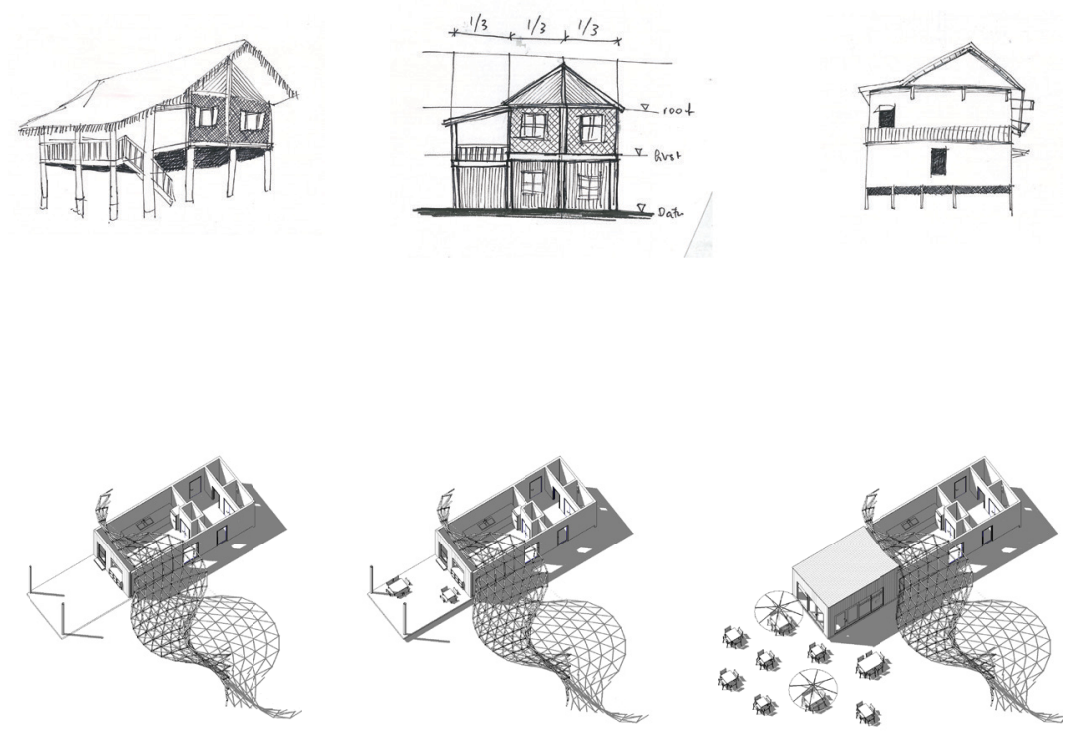

Figure 9.01

Early explorations from Myanmar style to the shop-house 


\section{Limitations}

Methods and modes of incorporation into a host society are nuanced and complex (Marlowe et al, 2014) and this thesis lacks the scope to adequately delve into this. For this reason, primary sources with specific needs are emphasised and a specific outcome has been produced.

I am not a member of the Myanmar Ethnics group, and there is not a lot of secondary research available on the Myanmar cultures' spatial values. For this reason, much of the research has been contextdriven, meaning that it is driven by specific information gathered from community members or, specific to a Wellington and New Zealand context.

This is an attempt to create a pragmatic project which could function on the stage of Wellington's everyday life. This is also a limitation because the information gathered is not from multiple sources that would produce an accurate and in-depth study. Another approach would have been a participatory design process, however the time and the scope of this thesis did not support this. 

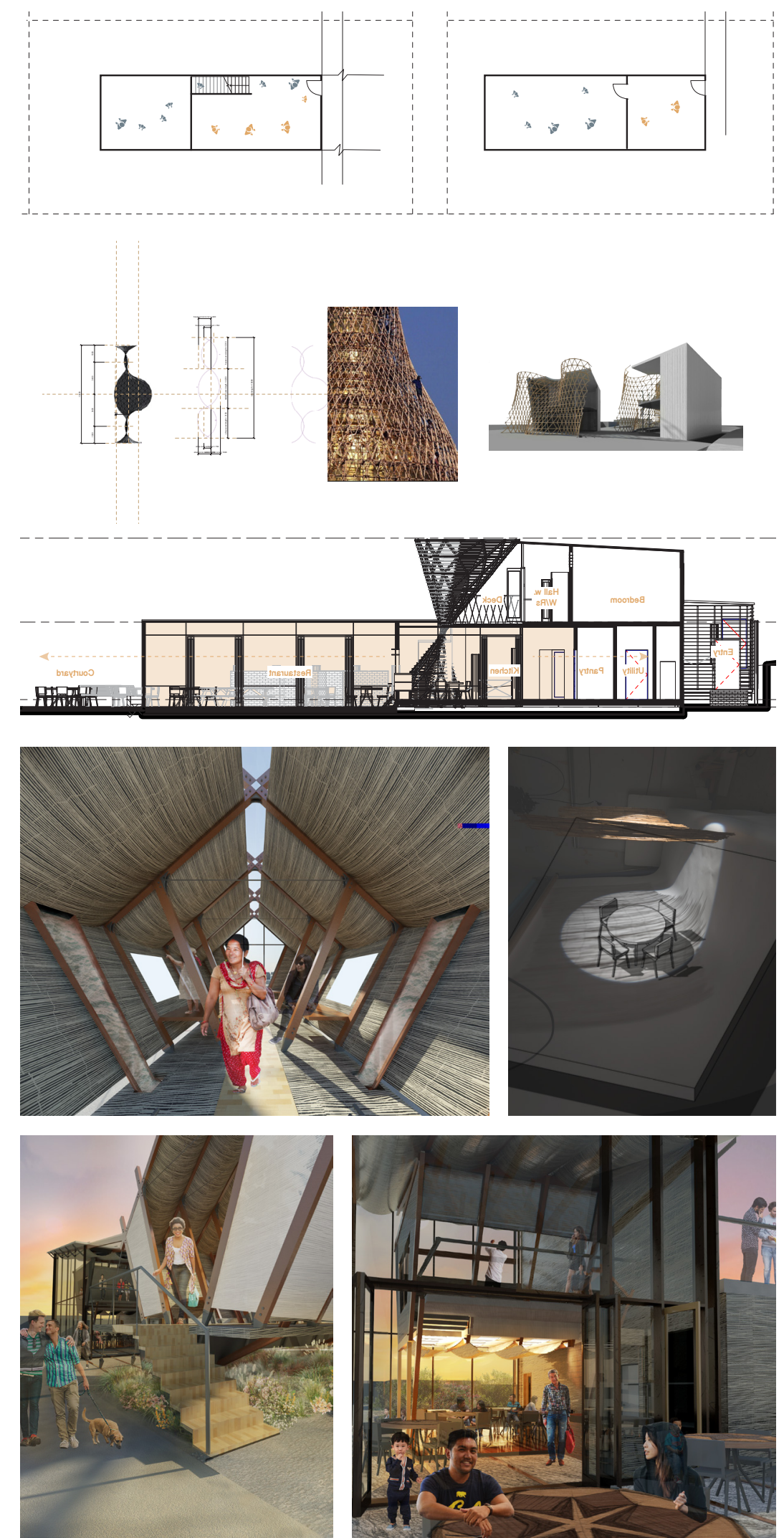

Figure 9.02 From preliminary to developed design process 


\section{Critical Reflection and Conclusion}

Resettling refugees is a complex problem which does not have any easy solutions, but architecture can play a role in providing culturallysensitive design, which can also act as an opportunity for self-employment and potentially create a meaningful space for a community. There are many options for how this building could manifest, which includes a variety of social housing options, and a limitless variety of shophouse types. There is value in culturally-sensitive design which can be seen in Te Aro Pā's aim to be an edifice for its tupuna, and Housing New Zealand's Māori and Pacific design guides.

Myanmar Ethnics is a large and permanent community in New Zealand, who have different spatial values than typical New Zealanders. A dwelling, which is designed to meet specific cultural and spatial needs while providing the opportunity for self-employment would be a valuable solution to the refugee population's struggle with earning enough money to meet their everyday needs.

The preliminary design process struggled to develop a coherent architectural language that visually differentiated the business from the dwelling. This is possibly because as an old building type, the shop-house has already developed effective techniques for this, such as the veranda. As a thesis, which combined multiple topics into a single design output, further reflection would delve deeper into the details of various devices shop-houses use to achieve this.

A central courtyard proved to be a valuable architectural device for both the potential growth of a business, and as a space in which various site functions could connect. However, in the shop-house type iteration the projecting growth of the potential business did not create a meaningful public space which connected with its surroundings. Essentially, this iteration proved that designing a low-density shophouse does not provide enough opportunities of encouraging an intercultural dialogue with the wider community.

Further reflection into this showed that, with an intervention such as a fresh water fountain-site, which could have specific meaning for the community who use it, the site could become an active place, visited throughout the day by diverse members of the wider community. This intervention, the 


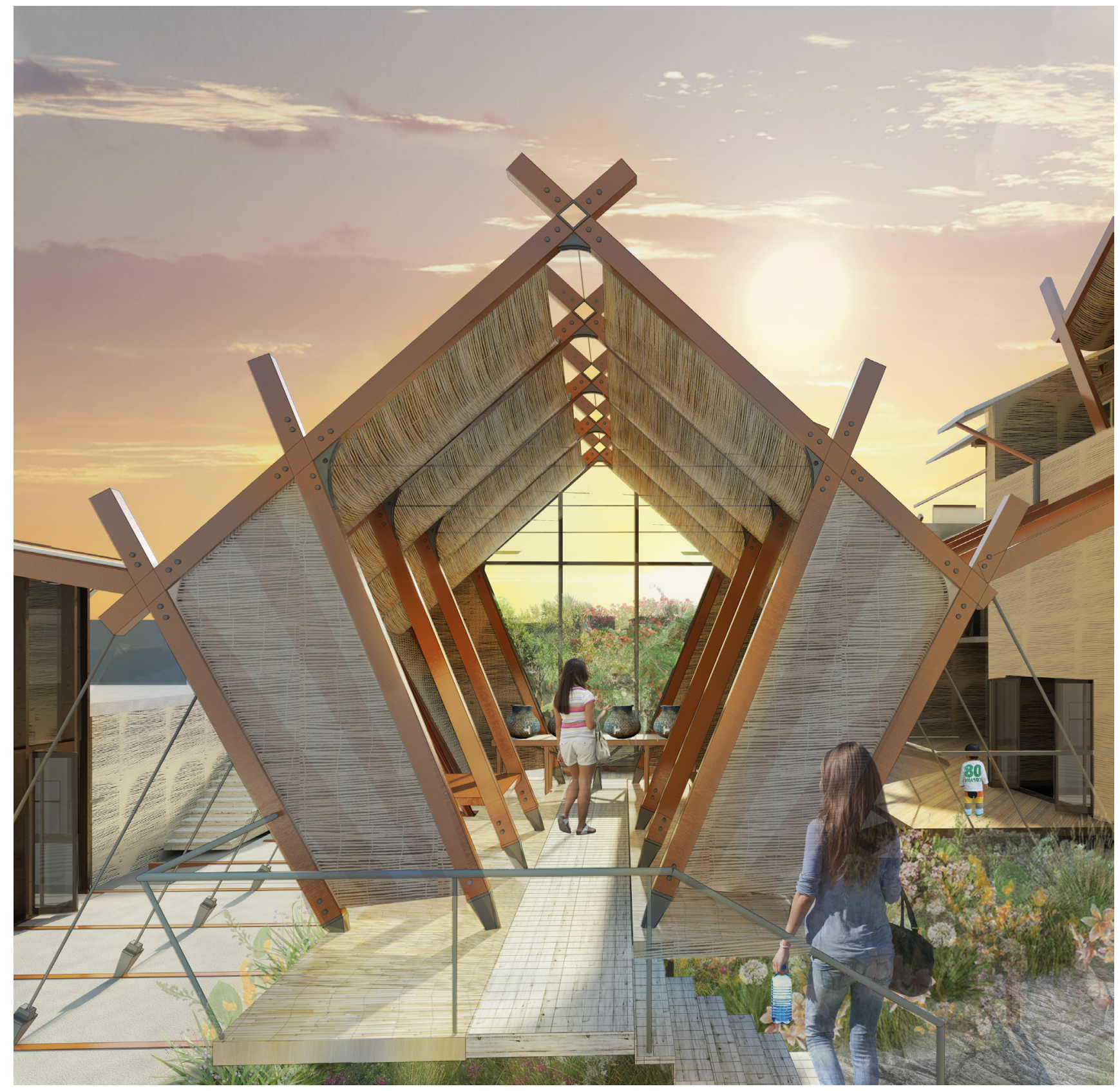

Figure $9.02 \quad$ The pivotal and potent moment of connection - The Rainwater Well. 
Rainwater Well, proved to be the key design moment needed to encourage intercultural dialogue between the refugee and wider community.

Pomegranate Kitchen's success in Wellington shows that a refugee-run food business could be considered on a larger scale.

The site was chosen to be physically and visually accessible for the Myanmar Ethnics and the wider community, however designing an active site with various functions proved to be a difficult task in a low-density environment. Further exploration would either conduct a more detailed site investigation or it would explore a site in Wellington city, such as the site of the Gordon Wilson flats which are being demolished.
This thesis has developed a potential design method for thoughtfully and compassionately integrating refugees into New Zealand over a long-term resettlement period. Refugees are rich with potential, and designing pragmatic architecture to meet their specific needs is a crucial and potent investigation which could lead to a better world.

Further investigation into the topics of this thesis could pursue: - potential evolution of dwellings with opportunities for selfemployment over a time scale ( 5 years, 10 years, 20 years, 100 years) - use of urban or environmental design techniques to create direct connections to distinctive local places, to connect the spaces further to their context - a participatory design process with a refugee community - investigative design into a local hub which could provide more services to the community 



\section{Figure list}

All images are authors own, except when otherwise attributed

\section{Introduction}

Figure 0.04 Photograph by Ross Giblin (2016). The first emergency intake of Syrian refugees lands in Wellington. Stuff.co.nz. Accessed on 21/04/17 from: http://www.stuff.co.nz/ national/77319562/the-first-emergency-intake-of-syrian-refugeeslands-in-wellington

Figure 0.06 Photograph by unknown author (Unknown Date). State houses at Arapuni Hydro Works. Archives New Zealand. Accessed on 21/04/17 from: https://www.flickr.com/photos/ archivesnz/3307743669\#

Figure 0.11 Images adapted from MBIE (2017). The Refugee and Protection Unit.

Accessed on 21/04/17 from: https://www.immigration.govt.nz/ documents/statistics/rqbresettlementstatpak.pdf

\section{Section One}

Figure 1.03 Photograph by Mathias Eick (2013). Myanmar/ Burma: Little hope for Rohingya IDPs.

Accessed on 21/04/17 from: https://www.flickr.com/photos/eu_ echo/10015500834

\section{Section Two}

Figure 2.02 Drawing by Hawkins Construction (2016). Arlington Apartments. Stuff.co.nz Accessed on 21/04/17 from: http://www.stuff.co.nz/ business/89703448/wellington-city-council-to-build-750-homes-toavoid-aucklandstyle-housing-crisis

Figure 2.03 Drawing by Jasmax, in association with designTRIBE (2016). Tamaki Neighbourhood Plans. Jasmax.

Accessed on 29/04/17 from: http://www.jasmax.com/work/tamakineighbourhood-plans/

\section{Section Three}

Figure 3.01 Drawings by Frances Hollis. Pattern Book. Work Home. 
Accessed on 29/04/17 from: http://www.theworkhome.com/ introducing-pattern-book/

Figure 3.04 2/ Photograph by Calvin Teo (2006). Geylang Road Shophouses. Wikimedia Commons.

Accessed on 21/04/17 from: https://commons.wikimedia.org/ wiki/File:Geylang_Road_Shophouses.jpg

6/Photograph by Max Pixel (2016). Ancient Trade Showcase Traditional Chandlery Shop.

Accessed on 21/04/17 from: http://maxpixel.freegreatpicture. com/Ancient-Trade-Showcase-Traditional-Chandlery-

Shop-1686779

Figure 3.06 Photograph by Beast from the Bush (2005). Arrowtown Chinese Settlement.

Accessed on 29/04/17 from: https://nzhistory.govt.nz/media/ photo/arrowtown-chinese-settlement

\section{Section Four}

Figure 4.01

1. Photograph incorporated into author's own collage by Nick Kenrick (1999). Bagan, Burma. Flickr.

Accessed on 21/04/17 from: https://www.flickr.com/ photos/33363480@N05/4031536093

2. Photograph incorporated into author's own collage by Mathias Eick (2013). Myanmar/Burma: Little hope for Rohingya IDPs. Accessed on 21/04/17 from: https://www.flickr.com/photos/ eu_echo/10015500834

Figure 4.04 Image adapted from Oo, C., Murakawa, S., Sakaue, K., Nishina, D., Koshikawa, Y., \& Yakushijin, A. (2003). Study on the Indigenous Building Materials of Traditional Houses in Myanmar. Journal of Asian Architecture and Building Engineering, 2(1), 163.

Figure 4.08 Photograph by Lionslayer (2012). A Myanmar traditional snack shop at Yaykyaw Thadingyut, Yangon. Wikimedia Commons.

Accessed on 21/04/17 from: https://commons.wikimedia.org/ wiki/File:A_Myanmar_tradational_snack_shop_at_Yaykyaw_ Thadingyut_Yangon.JPG

Figure 4.10 Photographs by Julia Raff and designed by Ackermann+Raff (2014). High School Thazin. ArchDaily. Accessed on 21/04/17 from: http://www.archdaily. com/534728/high-school-thazin-ackermann-raff 
Figure 4.11 Photograph and design by a.gor.a architects. Temporary Dormitories for Mae Tao Clinic. Designboom. Accessed on 21/04/17 from: http://www.designboom.com/ architecture/a-gor-a-architects-temporary-dormitories-for-mae-taoclinic/

Figure 4.12 Photograph by Pasi Aalto and design by TYIN tegnestue Architects (2009). TYIN Soe Ker Tie houses. Wikimedia Commons.

Accessed on 21/04/17 from: https://commons.wikimedia.org/wiki/ File:TYIN_Soe_Ker_Tie_houses.jpg

\section{Section Seven}

Figure 7.01 Photographs by Thomas Walden Levy (2014). How a Buddhist Shrine Transformed a Neighborhood in Oakland. Public Radio International.

Accessed on 21/04/17 from:

https://www.pri.org/stories/2014-11-19/how-buddhist-shrinetransformed-neighborhood-oakland

Figure 7.02 Images by Liz Ogbu (2005-2010). Day Labour Station. Accessed on 21/04/17 from: http://www.lizogbu.com/portfolio_ page/daylaborstation/ 



\section{Works Cited}

Adams, B. (2016). Letter to Thailand Prime Minister on UN Security Council Candidacy.

Retrieved from https://www.hrw.org/news/2016/06/27/letterthailand-prime-minister-un-security-council-candidacy

Broman, B. M. (2005). Myanmar Architecture: Cities of Gold: Times Editions, Marshall Cavendish.

Cairns, S. (2004). Drifting: Architecture and Migrancy: Routledge.

Cantle, T. (2012). Interculturalism: For the Era of Globalisation, Cohesion and Diversity. Political Insight, 3(3), 38-41.

Cooper, S., \& Ratele, K. (2014). Psychology Serving Humanity: Proceedings of the 30th International Congress of Psychology: Volume 2: Western Psychology: Taylor \& Francis.

Davis, H. (2012). Living Over the Store: Architecture and Local Urban Life: Taylor \& Francis.

Dawson, P. C. (2008). Unfriendly Architecture: Using Observations of Inuit Spatial Behavior to Design Culturally Sustaining Houses in Arctic Canada. Housing Studies, 23(1), 111-128.

Falconer, J., Invernizzi, L., Tettoni, L. I., \& Inglis, K. (1998). Myanmar style: art, architecture and design of Burma: Periplus.

Faumuina, P (2002). Pacific Housing Design guide. Housing New Zealand

Retrieved from http://www.hnzc.co.nz/assets/Uploads/pacifichousing-design-guide.pdf.

Gruner, A., \& Searle, W. (2012). New Zealand's Refugee Sector Department of Labour Retrieved from http://www.mbie.govt.nz/publications-research/ research/migration/perspectives-and-developments.pdf

Holliss, F. (2012). Home is Where the Work Is: The Case for an Urban Design Revolution. The Conversation.

Retrieved from https://theconversation.com/home-is-where-the-workis-the-case-for-an-urban-design-revolution-8147

Holliss, F. (2015). What the Future of Working at Home May Look Like. The Wall Street Journal

Retrieved from https://www.wsj.com/articles/what-the-future-of- 
working-at-home-may-look-like-1448248050

Holliss, F. (2015). Beyond Live/Work: The Architecture of Homebased Work: Taylor \& Francis.

Hoskins, R., Te-Nana, R., Rhodes, P., Guy, P., \& Sage, C. (2002). Ki te Hau Kainga: New Persepctives on Maori Housing Solutions. Housing New Zealand

Retrieved from http://www.hnzc.co.nz/assets/Uploads/ki-te-haukainga-new-perspectives-on-maori-housing-solutions.pdf.

Inglehart, R., \& Norris, P. (2016). Trump, Brexit, and the Rise of Populism: Economic Have-Nots and Cultural Backlash. Harvard Kennedy School.

Kamri-McGurk, U. (2012). Resettlement Experiences of Burmese Women from Refugee Backgrounds in Wellington, Aotearoa New Zealand. (Masters of Development Studies Degree), Victoria University of Wellington, Wellington, New Zealand. Retrieved from http://researcharchive.vuw.ac.nz/xmlui/ bitstream/handle/10063/2588/thesis.pdf?sequence $=1$

Kivisto, P. (2008). Multiculturalism in a Global Society: Wiley.

Leviathan. (2015). Arlington.

Retrieved from http://eyeofthefish.org/arlington/

Please note that appropriate information was requested from the WCC, but they could not supply it as they claimed it was currently unavailable.

MacKenzie, D. (2016). The Truth About Migration, How it will Reshape Our World. New Scientist.

Marlowe, J., Bartley, A., \& Hibtit, A., (2014). The New Zealand Refugee Resettlement Strategy: Implications for Identity, Acculturation and Civic Participation. Kōtuitui: New Zealand Journal of Social Sciences Online, 9(2).

MBIE. (2017). New Zealand Refugee Quota Programme. Retrieved from https://www.immigration.govt.nz/about-us/ what-we-do/our-strategies-and-projects/supporting-refugeesand-asylum-seekers/refugee-and-protection-unit/new-zealandrefugee-quota-programme

MBIE. (2015). Community Perceptions of Migrants and Immigration. (2015).

Retrieved from http://www.mbie.govt.nz/publications-research/ research/migrants---monitoring/community-survey-report.pdf.

MBIE. (2013). Refugee Settlement: New Zealand Resettlement 
Strategy.

Retrieved from https://www.immigration.govt.nz/documents/

refugees/refugeeresettlementstrategy.pdf.

MBIE. (2004). Refugee Voices: A Journey Towards Resettlement. Retrieved from http://www.mbie.govt.nz/publications-research/ research/migration/RefugeevoicesExecutiveSummary.pdf.

McLachlan, L. (2016). Papakainga Provides Affordable City Living. Radio New Zealand.

Retrieved from http://www.radionz.co.nz/news/regional/299330/ papakainga-provides-affordable-city-living

Nel, P., \& Abdullah, M. (2016). Immigrant Entrepreneurs and Their Perceived Success in Small Retail Businesses: Preliminary New Zealand Findings. Paper presented at the Annual South Africa Business Research Conference, Taj Hotel, Cape Town, South Africa.

New Zealand Red Cross. Who are Refugees?

Retrieved from https://www.redcross.org.nz/what-we-do/in-newzealand/refugee-programmes/who-are-refugees/

Oo, C., Murakawa, S., Sakaue, K., Nishina, D., Koshikawa, Y., \& Yakushijin, A. (2003). Study on the Indigenous Building Materials of Traditional Houses in Myanmar. Journal of Asian Architecture and Building Engineering, 2(1), 161-168.

Radford, T. (2015). Design is About People - Including Refugees. Retrieved from https://www.dezeen.com/2015/09/08/talia-radfordopinion-design-is-about-people-including-refugees-syria-crisis-austriaresponse/

Schulze, H. (2013). Immigration Policy Review. Berl Economics Retrieved from http://www.victoria.ac.nz/som/research/workingcapital/publications/Immigration-Policy-October-2013.pdf.

Searle, W., Prouse, E., L'Ami, E., Gray, A., \& Gruner, A. (2011). NewLand-New-Life-Longterm-Settlement-Refugees-Main-Report. MBIE Retrieved from http://www.mbie.govt.nz/publications-research/ research/migration/new-land-new-life-longterm-settlement-refugeessummary-report.pdf.

Silber, J. (2014). How a Buddhist Shrine Transformed a Neighborhood in Oakland. Public Radio International.

Sola, K. (2016). Inside Eat Offbeat, The Refugee-Run Kitchen That's Satisfying Adventurous Eaters With A Taste For Social Good. Forbes. 
Spoonley, P. (2012). Small Business: Immigrants setting up shop in NZ. New Zealand Herald.

Retrieved from http://www.nzherald.co.nz/business/news/

article.cfm?c_id=3\&objectid=10818373

Tamaki Regeneration Company. (2016). Tamaki Reference Plan Retrieved from http://www.tamakiregeneration.co.nz/sites/ default/files/site-files/TRC\%20Reference\%20Plan\%20resized.pdf

Tan, L. (2013). Burmese Largest Group of Refugees and Least Likely to Leave. NZ Herald.

Retrieved from http://www.nzherald.co.nz/nz/news/article. cfm?c_id=1\&objectid=10875026

Te Tumu Paeroa (Writer). (2016). Te Aro Pā Papakāinga Opening [Video file]: Te Tumu Paeroa.

Retrieved from: https://www.youtube.com/

watch?v=LyTL9iALM1M

UNHCR. (2016). UNHCR viewpoint: ‘Refugee' or 'migrant' - Which is right?

Retrieved from http://www.unhcr.org/news/

latest/2016/7/55df0e556/unhcr-viewpoint-refugee-migrant-

right.html

Van-Der-Laken, R. (2016). Designers Cannot Just Stand By and Watch as the Refugee Crisis Unfolds.

Retrieved from https://www.dezeen.com/2016/04/29/richardvan-der-laken-opinion-what-design-can-do-refugee-challenge-roledesigners-humanitarian-design/

Ward, C., Masgoret, A.-M., \& Vauclair, M. (2011). Attitudes Towards Immigrants and Immigrant Experiences: Predictive Models Based on Regional Characteristics. Wellington, New Zealand

Retrieved from http://www.mbie.govt.nz/publications-research/ research/migrants---settlement/attitudes-towards-migrants.pdf.

Wellington City Council, Selling Safe Food with Confidence. Retrieved from http://wellington.govt.nz/ /media/services/ consents-and-licenses/food-safety/files/safe-food.pdf.

Zhou, M. (1997). Segmented Assimilation: Issues, Controversies, and Recent Research on the New Second Generation. The International Migration Review, 31(4), 975-1008. 



\section{Appendix}

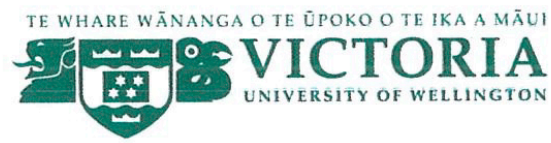

\section{[Critical building: live + work in Wellington] \\ CONSENT TO INTERVIEW}

This consent form will be held for 5 years.

Researcher: [Lucy Stronach, School of Architecture and Design, Victoria University of Wellington].

- I have read the Information Sheet and the project has been explained to me. My questions have been answered to my satisfaction. I understand that I can ask further questions at any time.

I understand that:

- I may withdraw from this study up to four weeks after the interview or by August 1st, and any information that I have provided will be returned to me or destroyed.

- The information I have provided will be destroyed 2 years after the research is finished.

- Any information I provide will be kept confidential to the researcher and the supervisor. I understand that the results will be used for a Masters thesis and a summary of the results may be used in academic reports and/or presented at conferences.

- $\quad$ My name will not be used in reports, nor will any information that would identify me.

- $\quad[O R]$ I consent to information or opinions which I have given Yes $\square$ No being attributed to me in any reports on this research:

- I would like a summary of my interview: Yes No

- I would like to receive a copy of the final thesis and have added my email Yes No address below.

Signature of participant:

Name of participant:

Date:

Contact details: 


\section{[Critical Building: live + work in New Zealand]}

\section{INTERVIEW QUESTIONS}

Researcher: [Lucy Stronach, School of Architecture and Design, Victoria University of Wellington].

\section{Part 1 - about you}

1. Where are you from?

2. What is your ethnicity?

3. What is your religion? tell me about it

4. How many people live in your house now? -and what is their relationship are they to you?

5. How long have you been in New Zealand for?

\section{Part 2 - Work/business}

6. Would you like to run a business? (If no what would you think about it?)

7. What sort of business would you like to run?

- And why?

8. Would you like to live on the same property as this business?

9. How would you like the business to be connected to the house?

10. How would you like the business to look from the outside? -What sort of colours or patterns?

-What sort of materials?

11. What would you like people to see from the outside (of the business)?

12. How would you like the business to look on the inside? -What sort of colours or patterns? 
-What sort of materials?

\section{Part 3 -the house}

13. Can you describe what your house was like before you came to New Zealand; from where you enter the house through to the rooms you move through as you go through the house.

14. How are the rooms in your house used?

15. What did you like about that that you would like to see in a house in New Zealand?

16. What do you like about your house in New Zealand?

17. What don't you like about your house in New Zealand?

18. What is the most important thing for you in a house, for example, privacy, warmth or energy efficiency?

19. How would you like the house to look from the outside?

-What sort of colours or patterns?

-What sort of materials?

20. How would you like the house to look on the inside?

-What sort of colours or patterns?

-What sort of materials?

21. Is there anything else that you would like in a house?

\section{Part 4 -visitors and privacy}

22. Where do you greet visitors on your property?

23. Which parts of the house are public and guest areas and which parts are personal and private?

\section{Part 5 - outdoor space}

24. How do you like to use the outdoor space around your house? For example do you like to garden?

25. What sort of things would you like to see in an outdoor space?

26. If you like gardening - what sort of gardening do you like to do? eg vegetable gardening, or growing flowers etc. 